\title{
Intermolecular hydropyridylation of unactivated alkenes
}

\author{
Xiaoshen $\mathrm{Ma}^{1}$ and Seth B. Herzon ${ }^{1,2} *$ \\ ${ }^{1}$ Department of Chemistry, Yale University, New Haven, CT 06520, United States \\ ${ }^{2}$ Department of Pharmacology, Yale School of Medicine, New Haven, CT 06520, United States \\ J. Am. Chem. Soc.
}

Supporting Information

\section{$\underline{\text { Index }}$}

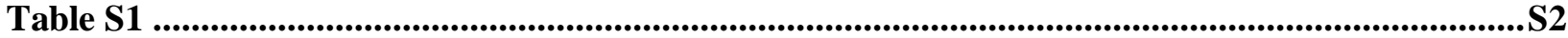

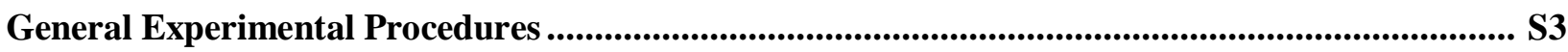

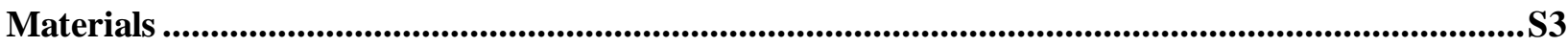

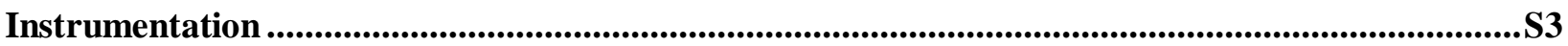

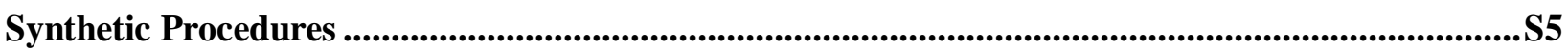

Catalog of Nuclear Magnetic Resonance Spectra, Infrared Spectra, and LC/MS Traces...............S59

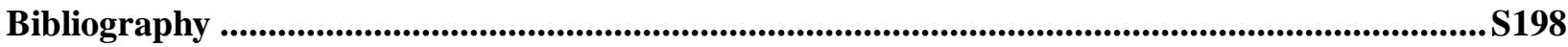




\begin{tabular}{|c|c|c|c|c|c|}
\hline \multicolumn{6}{|c|}{ Table S1. Optimization of the hydropyridylation. ${ }^{a}$} \\
\hline $1 \mathrm{a}$ & $\begin{array}{lll}\mathrm{CH}_{3} & \mathrm{C} \\
& \mathrm{l} \\
& \mathrm{OCH}\end{array}$ & \multicolumn{2}{|c|}{$\begin{array}{c}\mathrm{Co}(\mathrm{acac})_{2}(100 \mathrm{~mol} \%) \\
\mathrm{TBHP}(100 \mathrm{~mol} \%) \\
\text { lutidine derivative }(500 \mathrm{~mol} \%) \\
\stackrel{\mathrm{Et}_{3} \mathrm{SiH}(500 \mathrm{~mol} \%)}{\longrightarrow} \\
\mathrm{CH}_{2} \mathrm{Cl}_{2}(0.2 \mathrm{M}), \mathrm{Ar}, 24{ }^{\circ} \mathrm{C}\end{array}$} & (3a & $\begin{array}{r}\mathrm{PMPCO}_{2} \overbrace{\mathrm{C}}^{\mathrm{Y}} \\
4 \\
4\end{array}$ \\
\hline entry & variation $\mathrm{f}$ & & conv 1a & yield $\mathbf{3 a}{ }^{b}$ & yield 4 \\
\hline $1^{c}$ & & & $>95 \%$ & $(81 \%)$ & $10 \%$ \\
\hline 2 & THF instea & $\mathrm{Cl}_{2}$ & $77 \%$ & $<1 \%$ & $30 \%$ \\
\hline 3 & $\mathrm{CH}_{3} \mathrm{CN}$ inste & $\mathrm{H}_{2} \mathrm{Cl}_{2}$ & $>95 \%$ & $49 \%$ & $<1 \%$ \\
\hline 4 & toluene inste & $\mathrm{I}_{2} \mathrm{Cl}_{2}$ & $>95 \%$ & $<1 \%$ & $37 \%$ \\
\hline 5 & DMF instea & ${ }_{2} \mathrm{Cl}_{2}$ & $70 \%$ & $51 \%$ & $<1 \%$ \\
\hline 6 & $\mathrm{CH}_{3} \mathrm{OH}$ inste & $\mathrm{H}_{2} \mathrm{Cl}_{2}$ & $47 \%$ & $40 \%$ & $<1 \%$ \\
\hline 7 & DCE instea & & $>95 \%$ & $49 \%$ & $13 \%$ \\
\hline 8 & & & $>95 \%$ & $25 \%$ & $<1 \%$ \\
\hline 9 & & & $>95 \%$ & $57 \%$ & $18 \%$ \\
\hline 10 & $\mathrm{Co}(\mathrm{acac})_{2}$ & & $>95 \%$ & $52 \%$ & $6 \%$ \\
\hline 11 & $\mathrm{Et}_{3} \mathrm{SiH}(2$ & & $>95 \%$ & $51 \%$ & $5 \%$ \\
\hline 12 & $\mathbf{2 a}(250$ & & $>95 \%$ & $37 \%$ & $<1 \%$ \\
\hline
\end{tabular}

${ }^{a}$ General reaction conditions: 1a $(100 \mu \mathrm{mol}), \mathrm{Co}(\mathrm{acac})_{2}(100 \mathrm{~mol} \%), \mathrm{TBHP}(100 \mathrm{~mol} \%)$, lutidine derivative $(500 \mathrm{~mol} \%), \mathrm{Et} 3 \mathrm{SiH}$ $(500 \mathrm{~mol} \%), \mathrm{CH}_{2} \mathrm{Cl}_{2}(0.2 \mathrm{M}), 24{ }^{\circ} \mathrm{C}, 16 \mathrm{~h}$. Conversions and yields were determined by ${ }^{1} \mathrm{H}$ NMR spectroscopy using mesitylene as an internal standard. ${ }^{b}$ Yields in parentheses are isolated yields after purification by flash-column chromatography. ${ }^{c}$ Reaction employed $250 \mu \mathrm{mol}$ of $\mathbf{1 a}$. 
General Experimental Procedures. All reactions were performed in single-neck, flame-dried, roundbottomed flasks fitted with rubber septa under a positive pressure of argon, unless otherwise noted. Airand moisture-sensitive liquids were transferred via syringe or stainless steel cannula, or were handled in a nitrogen-filled drybox (working oxygen level $<5 \mathrm{ppm}$ ). Organic solutions were concentrated by rotary evaporation at $30-33{ }^{\circ} \mathrm{C}$. Intermediates were purified using a Biotage Isolera system, employing

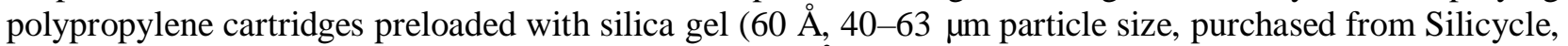
Quebec City, Canada) or neutral aluminium oxide (60 A, 50-200 $\mu \mathrm{m}$ particle size, purchased from Acros Organics, New Jersey, USA). Alternatively, intermediates were purified using a Teledyne ISCO system, employing RediSep Rf High Performance Gold cartridges (RediSep Rf Gold Silica, 20-40 um spherical, purchased from Teledyne ISCO, Dallas, Texas). Samples were eluted using a flow rate of $12-50 \mathrm{~mL} / \mathrm{min}$, with detection by UV $(254 \mathrm{~nm})$. Analytical thin-layered chromatography (TLC) was performed using glass plates pre-coated with silica gel $(0.25 \mathrm{~mm}, 60 \AA$ A pore size $)$ impregnated with a fluorescent indicator $(254$ $\mathrm{nm}$ ). TLC plates were visualized by exposure to ultraviolet light (UV) and/or submersion in aqueous ceric ammonium molybdate solution (CAM) or aqueous potassium permanganate solution $\left(\mathrm{KMnO}_{4}\right)$, followed by brief heating on a hot plate $\left(120^{\circ} \mathrm{C}, 10-15 \mathrm{~s}\right)$.

Materials. Commercial solvents and reagents were used as received with the following exceptions. Acetonitrile and toluene were purified according to the method of Pangborn et al. ${ }^{1}$ Dichloromethane was purified according to the method of Pangborn et al, ${ }^{1}$ degassed by three freeze-pump-thaw cycles, and stored under an atmosphere of argon over $4 \AA$ molecular sieves before use. 1,2-Dichloroethane, acetone, chloroform, and pyridine were distilled from calcium hydride under an atmosphere of nitrogen immediately before use. Cyclohexene, trans-hex-3-ene, 1-methylcyclohexene, 2,3-dimethyl-2-butene, and methylenecyclobutane were dried over calcium hydride overnight, degassed by three freeze-pump-thaw cycles, and vacuum transferred immediately before use. Methyl triflate was distilled under reduced pressure immediately before use. Commercial anhydrous $N, N$-dimethylformamide (Sigma-Aldrich Corporation, St. Louis, MO) was degassed by three freeze-pump-thaw cycles and stored over activated $4 \AA$ MS under an atmosphere of nitrogen before use. Tetrahydrofuran was distilled from sodiumbenzophenone under an atmosphere of nitrogen immediately before use. Triethylamine and $\mathrm{N}, \mathrm{N}$ diisopropylethylamine was distilled from calcium hydride under an atmosphere of nitrogen immediately before use. Methanol was distilled from magnesium under an atmosphere of nitrogen immediately before use. Triethylsilane was degassed by three freeze-pump-thaw cycles and stored under an atmosphere of argon before use. Cobalt bis(acetylacetonate) was dried by heating overnight in vacuo $\left(70{ }^{\circ} \mathrm{C}, 200 \mathrm{mTorr}\right)$, and stored under an atmosphere of argon before use. E-(4-iodo-3-methylbut-3-en-1-yl)benzene, ${ }^{2}{ }^{4-}$ azidobenzyl alcohol, ${ }^{3}$ 4-methyl-4-pentenoic acid, ${ }^{4}$ and $\left(\eta^{6}\right.$-benzene) manganese tricarbonyl hexafluorophosphate ${ }^{5}$ were prepared according to published procedures. The concentration of $n$ butyllithium in hexanes was determined by titration against a standard solution of diphenylacetic acid (average of three determinations). ${ }^{6}$

Instrumentation. Proton nuclear magnetic resonance spectra $\left({ }^{1} \mathrm{H}\right.$ NMR) were recorded at 400, 500, or 600 $\mathrm{MHz}$ at $24{ }^{\circ} \mathrm{C}$, unless otherwise noted. Chemical shifts are expressed in parts per million (ppm, $\delta$ scale) downfield from tetramethylsilane and are referenced to residual protium in the NMR solvent $\left(\mathrm{CHCl}_{3}, \delta\right.$ 7.26; $\left.\mathrm{CHD}_{2} \mathrm{SOCD}_{3}, \delta 2.50\right)$. Data are represented as follows: chemical shift, multiplicity $(\mathrm{s}=$ singlet, $\mathrm{d}=$ doublet, $\mathrm{t}=$ triplet, $\mathrm{q}=$ quartet, $\mathrm{m}=$ multiplet and/or multiple resonances, $\mathrm{br}=$ broad), integration, coupling constant in Hertz, and assignment. Proton-decoupled carbon nuclear magnetic resonance spectra $\left({ }^{13} \mathrm{C}\right.$ NMR) were recorded at 100,125 , or $150 \mathrm{MHz}$ at $24{ }^{\circ} \mathrm{C}$, unless otherwise noted. Chemical shifts are expressed in parts per million (ppm, $\delta$ scale) downfield from tetramethylsilane and are referenced to the carbon resonances of the solvent $\left(\mathrm{CDCl}_{3}, \delta 77.0 ;\left(\mathrm{CD}_{3}\right)_{2} \mathrm{SO}, \delta\right.$ 39.5). Distortionless enhancement by polarization transfer spectra [DEPT (135)] were recorded at 100,125 , or $150 \mathrm{MHz}$ at $24{ }^{\circ} \mathrm{C}$, unless otherwise noted. ${ }^{13} \mathrm{C}$ NMR and DEPT (135) data are combined and represented as follows: chemical shift, carbon type [obtained from DEPT (135) experiments]. Proton-decoupled fluorine nuclear magnetic resonance spectra $\left({ }^{19} \mathrm{~F}\right.$ NMR) were recorded at $375 \mathrm{MHz}$ at $24{ }^{\circ} \mathrm{C}$, unless otherwise noted. Chemical shifts 
are expressed in parts per million (ppm, $\delta$ scale) downfield from fluorotrichloromethane. Attenuated total reflectance Fourier transform infrared spectra (ATR-FTIR) were obtained using a Thermo Electron Corporation Nicolet 6700 FTIR spectrometer referenced to a polystyrene standard. Data are represented as follows: frequency of absorption $\left(\mathrm{cm}^{-1}\right)$, intensity of absorption $(\mathrm{s}=$ strong, $\mathrm{m}=$ medium, $\mathrm{w}=$ weak, $\mathrm{br}=$ broad). Analytical ultra high-performance liquid chromatography/mass spectrometry (UPLC/MS) was performed on a Waters UPLC/MS instrument equipped with a reverse-phase $\mathrm{C}_{18}$ column (1.7 $\mu \mathrm{m}$ particle size, $2.1 \times 50 \mathrm{~mm}$ ), dual atmospheric pressure chemical ionization (API)/electrospray (ESI) mass spectrometry detector, and photodiode array detector. Samples were eluted with a linear gradient of $20 \%$ acetonitrile-water containing $0.1 \%$ formic acid $\rightarrow 100 \%$ acetonitrile containing $0.1 \%$ formic acid over 3 min, followed by $100 \%$ acetonitrile containing $0.1 \%$ formic acid for $1 \mathrm{~min}$, at a flow rate of $800 \mu \mathrm{L} / \mathrm{min}$. High-resolution mass spectrometry (HRMS) were obtained on a Waters UPLC/HRMS instrument equipped with a dual API/ESI high-resolution mass spectrometry detector and photodiode array detector. Unless otherwise noted, samples were eluted over a reverse-phase C18 column $(1.7 \mu \mathrm{m}$ particle size, $2.1 \times 50 \mathrm{~mm})$ with a linear gradient of $5 \%$ acetonitrilewater containing $0.1 \%$ formic acid $\rightarrow 95 \%$ acetonitrile-water containing $0.1 \%$ formic acid over $1.6 \mathrm{~min}$, followed by $100 \%$ acetonitrile containing $0.1 \%$ formic acid for $1 \mathrm{~min}$, at a flow rate of $600 \mu \mathrm{L} / \mathrm{min}$. 


\section{Synthetic Procedures.}

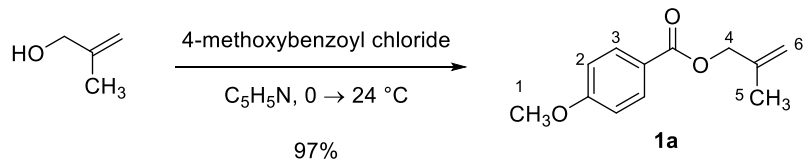

Preparation of 2-methylallyl 4-methoxybenzoate (1a):

4-Methoxybenzoyl chloride ( $1.50 \mathrm{~g}, 8.80 \mathrm{mmol}, 1.10$ equiv) was added dropwise via syringe to a solution of 2-methyl-2-propen-1-ol (576 mg, $8.00 \mathrm{mmol}, 1$ equiv) in pyridine $(32 \mathrm{~mL})$ at $0{ }^{\circ} \mathrm{C}$. The reaction mixture was stirred for $30 \mathrm{~min}$ at $0{ }^{\circ} \mathrm{C}$, and then the ice bath was removed. The reaction mixture was stirred for $24 \mathrm{~h}$ at $24{ }^{\circ} \mathrm{C}$. The product mixture was transferred to a separatory funnel that had been charged with ethyl acetate $(50 \mathrm{~mL})$. The diluted product mixture was washed with saturated aqueous sodium bicarbonate solution $(50 \mathrm{~mL})$. The aqueous layer was isolated and the isolated aqueous layer was extracted with ethyl acetate $(3 \times 50 \mathrm{~mL})$. The organic layers were combined and the combined organic layers were dried over sodium sulfate. The dried solution was filtered and the filtrate was concentrated. The residue obtained was purified by automated flash-column chromatography (eluting with 5\% ethyl acetate-hexanes initially, grading to $10 \%$ ethyl acetate-hexanes, linear gradient) to afford 2-methylallyl 4methoxybenzoate (1a) as a colorless oil (1.60 g, 97\%).

$\mathrm{R}_{f}=0.55\left(20 \%\right.$ ethyl acetate-hexanes; UV, $\left.\mathrm{KMnO}_{4}\right) .{ }^{1} \mathrm{H} \mathrm{NMR}\left(600 \mathrm{MHz}, \mathrm{CDCl}_{3}\right) \delta 8.02(\mathrm{~d}, 2 \mathrm{H}, \mathrm{J}=8.4$ $\left.\mathrm{Hz}, \mathrm{H}_{3}\right), 6.92\left(\mathrm{~d}, 2 \mathrm{H}, \mathrm{J}=8.4 \mathrm{~Hz}, \mathrm{H}_{2}\right), 5.05\left(\mathrm{~s}, 1 \mathrm{H}, \mathrm{H}_{6}\right), 4.96\left(\mathrm{~s}, 1 \mathrm{H}, \mathrm{H}_{6}\right), 4.71\left(\mathrm{~s}, 2 \mathrm{H}, \mathrm{H}_{4}\right), 3.87\left(\mathrm{~s}, 3 \mathrm{H}, \mathrm{H}_{1}\right)$, $1.82\left(\mathrm{~s}, 3 \mathrm{H}, \mathrm{H}_{5}\right) .{ }^{13} \mathrm{C}$ NMR $\left(150 \mathrm{MHz}, \mathrm{CDCl}_{3}\right) \delta 166.0(\mathrm{C}), 163.4(\mathrm{C}), 140.2(\mathrm{C}), 131.6(\mathrm{CH}), 122.6(\mathrm{C})$, $113.6(\mathrm{CH}), 112.7\left(\mathrm{CH}_{2}\right), 67.8\left(\mathrm{CH}_{2}\right), 55.4\left(\mathrm{CH}_{3}\right), 19.6\left(\mathrm{CH}_{3}\right)$.

${ }^{1} \mathrm{H}$ and ${ }^{13} \mathrm{C}$ NMR data for 2-methylallyl 4-methoxybenzoate (1a) prepared in this way were in agreement with those previously described. ${ }^{7}$ 


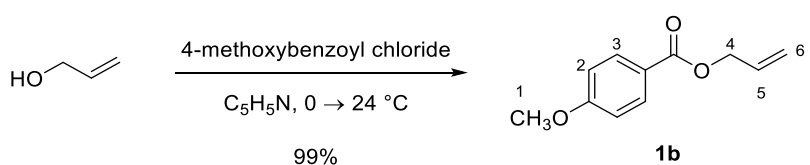

Preparation of allyl 4-methoxybenzoate $(\mathbf{1 b})$ :

4-Methoxybenzoyl chloride ( $1.50 \mathrm{~g}, 8.80 \mathrm{mmol}, 1.10$ equiv) was added dropwise via syringe to a solution of allyl alcohol $\left(464 \mathrm{mg}, 8.00 \mathrm{mmol}, 1\right.$ equiv) in pyridine $(32 \mathrm{~mL})$ at $0{ }^{\circ} \mathrm{C}$. The reaction mixture was stirred for $30 \mathrm{~min}$ at $0{ }^{\circ} \mathrm{C}$, and then the ice bath was removed. The reaction mixture was stirred for 24 $\mathrm{h}$ at $24{ }^{\circ} \mathrm{C}$. The product mixture was transferred to a separatory funnel that had been charged with ethyl acetate $(50 \mathrm{~mL})$. The diluted product mixture was washed with saturated aqueous sodium bicarbonate solution $(50 \mathrm{~mL})$. The aqueous layer was isolated and the isolated aqueous layer was extracted with ethyl acetate $(3 \times 50 \mathrm{~mL})$. The organic layers were combined and the combined organic layers were dried over sodium sulfate. The dried solution was filtered and the filtrate was concentrated. The residue obtained was purified by automated flash-column chromatography (eluting with 5\% ethyl acetate-hexanes initially, grading to $10 \%$ ethyl acetate-hexanes, linear gradient) to afford allyl 4-methoxybenzoate (1b) as a colorless oil (1.54 g, 99\%).

$\mathrm{R}_{f}=0.55$ (20\% ethyl acetate-hexanes; UV, $\left.\mathrm{KMnO}_{4}\right) .{ }^{1} \mathrm{H} \mathrm{NMR}\left(600 \mathrm{MHz}, \mathrm{CDCl}_{3}\right) \delta 8.02(\mathrm{~d}, 2 \mathrm{H}, \mathrm{J}=8.4$ $\left.\mathrm{Hz}, \mathrm{H}_{3}\right), 6.92\left(\mathrm{~d}, 2 \mathrm{H}, \mathrm{J}=8.4 \mathrm{~Hz}, \mathrm{H}_{2}\right), 6.03$ (ddt, J = 16.8, 10.2, $\left.4.2 \mathrm{~Hz}, 1 \mathrm{H}, \mathrm{H}_{5}\right), 5.40(\mathrm{~d}, \mathrm{~J}=16.8 \mathrm{~Hz}, 1 \mathrm{H}$, $\left.\mathrm{H}_{6}\right), 5.27\left(\mathrm{~d}, \mathrm{~J}=10.2 \mathrm{~Hz}, 1 \mathrm{H}, \mathrm{H}_{6}\right), 4.80\left(\mathrm{~d}, \mathrm{~J}=4.2 \mathrm{~Hz}, 2 \mathrm{H}, \mathrm{H}_{4}\right), 3.86\left(\mathrm{~s}, 3 \mathrm{H}, \mathrm{H}_{1}\right) .{ }^{13} \mathrm{C} \mathrm{NMR}(150 \mathrm{MHz}$, $\left.\mathrm{CDCl}_{3}\right) \delta 166.0(\mathrm{C}), 163.4(\mathrm{C}), 132.5(\mathrm{CH}), 131.6(\mathrm{CH}), 122.5(\mathrm{C}), 117.9\left(\mathrm{CH}_{2}\right), 113.6(\mathrm{CH}), 65.2\left(\mathrm{CH}_{2}\right)$, $55.4\left(\mathrm{CH}_{3}\right)$.

${ }^{1} \mathrm{H}$ and ${ }^{13} \mathrm{C}$ NMR data for allyl 4-methoxybenzoate (1b) prepared in this way were in agreement with those previously described. ${ }^{8}$ 


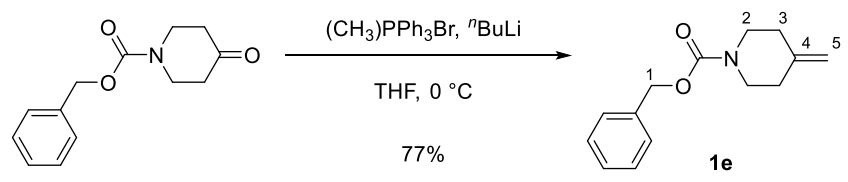

Preparation of benzyl 4-methylenepiperidine-1-carboxylate (1e):

A $250-\mathrm{mL}$ round-bottomed flask that had been fused to a Teflon-coated valve was charged with methyltriphenylphosphonium bromide $(4.29 \mathrm{~g}, 12.0 \mathrm{mmol}, 1.20$ equiv). The reaction vessel was evacuated and refilled using a balloon of argon. This process was repeated twice. Tetrahydrofuran $(60 \mathrm{~mL})$ was added to the reaction vessel via syringe and the resulting mixture was cooled to $0{ }^{\circ} \mathrm{C}$. A solution of $n$ butyllithium in hexanes $(2.42 \mathrm{M}, 4.96 \mathrm{~mL}, 12.0 \mathrm{mmol}, 1.20$ equiv) was added dropwise via syringe to the cold mixture. The reaction mixture was stirred for $1 \mathrm{~h}$ at $0{ }^{\circ} \mathrm{C}$. A $25-\mathrm{mL}$ round-bottomed flask was charged with benzyl 4-oxopiperidine-1-carboxylate $(2.33 \mathrm{~g}, 10.0 \mathrm{mmol}, 1$ equiv). The vessel containing the starting material was evacuated and refilled using a balloon of argon. This process was repeated twice. Tetrahydrofuran $(10 \mathrm{~mL})$ was added to the vessel containing the starting material and the resulting solution was transferred via cannula to the ylide solution. The reaction mixture was stirred at $0{ }^{\circ} \mathrm{C}$ for $1 \mathrm{~h}$ and then was allowed to warm over $30 \mathrm{~min}$ to $24{ }^{\circ} \mathrm{C}$. The warmed product mixture was filtered through a pad of silica gel and the pad was rinsed with ethyl acetate $(50 \mathrm{~mL})$. The filtrates were combined and the combined filtrates were concentrated. The residue obtained was purified by automated flash-column chromatography (eluting with $5 \%$ ethyl acetate-hexanes initially, grading to $10 \%$ ethyl acetate-hexanes, linear gradient) to afford benzyl 4-methylenepiperidine-1-carboxylate (1e) as a colorless oil (1.78 g, 77\%).

$\mathrm{R}_{f}=0.27$ (20\% ethyl acetate-hexanes; UV, $\left.\mathrm{KMnO}_{4}\right) .{ }^{1} \mathrm{H}$ NMR $\left(400 \mathrm{MHz}, \mathrm{CDCl}_{3}\right) \delta 7.36-7.30(\mathrm{~m}, 5 \mathrm{H}$, $\mathrm{ArH}), 5.14\left(\mathrm{~s}, 2 \mathrm{H}, \mathrm{H}_{5}\right), 4.75\left(\mathrm{~s}, 2 \mathrm{H}, \mathrm{H}_{1}\right), 3.50\left(\mathrm{br} \mathrm{s}, 4 \mathrm{H}, \mathrm{H}_{2}\right), 2.19$ (br s, 4H, $\left.\mathrm{H}_{3}\right) .{ }^{13} \mathrm{C} \mathrm{NMR}(150 \mathrm{MHz}$, $\left.\mathrm{CDCl}_{3}\right) \delta 155.1(\mathrm{C}), 144.8(\mathrm{C}), 136.8(\mathrm{C}), 128.4(\mathrm{CH}), 127.9(\mathrm{CH}), 127.8(\mathrm{CH}), 109.4\left(\mathrm{CH}_{2}\right), 67.1\left(\mathrm{CH}_{2}\right)$, $45.5\left(\mathrm{CH}_{2}\right), 34.5\left(\mathrm{CH}_{2}\right)$.

${ }^{1} \mathrm{H}$ and ${ }^{13} \mathrm{C}$ NMR data for benzyl 4-methylenepiperidine-1-carboxylate (1e) prepared in this way were in agreement with those previously described. ${ }^{9}$ 


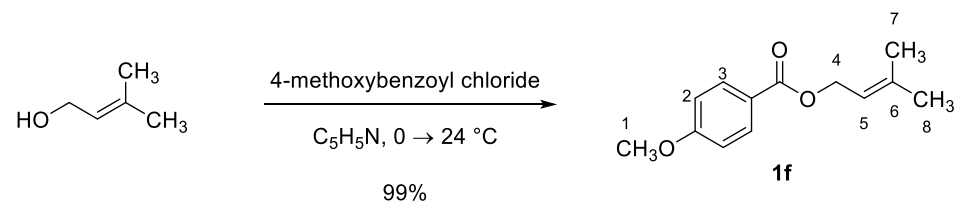

Preparation of 3-methylbut-2-en-1-yl 4-methoxybenzoate (1f):

4-Methoxybenzoyl chloride (563 mg, $3.30 \mathrm{mmol}, 1.10$ equiv) was added dropwise via syringe to a solution of 3-methylbut-2-en-1-ol (258 mg, $3.00 \mathrm{mmol}, 1$ equiv) in pyridine $(12 \mathrm{~mL})$ at $0{ }^{\circ} \mathrm{C}$. The reaction mixture was stirred for $30 \mathrm{~min}$ at $0{ }^{\circ} \mathrm{C}$, and then the ice bath was removed. The reaction mixture was stirred for $24 \mathrm{~h}$ at $24{ }^{\circ} \mathrm{C}$. The product mixture was transferred to a separatory funnel that had been charged with ethyl acetate $(20 \mathrm{~mL})$. The diluted product mixture was washed with saturated aqueous sodium bicarbonate solution $(20 \mathrm{~mL})$. The aqueous layer was isolated and the isolated aqueous layer was extracted with ethyl acetate $(3 \times 20 \mathrm{~mL})$. The organic layers were combined and the combined organic layers were dried over sodium sulfate. The dried solution was filtered and the filtrate was concentrated. The residue obtained was purified by automated flash-column chromatography (eluting with 5\% ethyl acetate-hexanes initially, grading to $10 \%$ ethyl acetate-hexanes, linear gradient) to afford 3-methylbut-2-en-1-yl 4methoxybenzoate (1f) as a colorless oil (661 $\mathrm{mg}, 99 \%)$.

$\mathrm{R}_{f}=0.55$ (20\% ethyl acetate-hexanes; UV, $\left.\mathrm{KMnO}_{4}\right) .{ }^{1} \mathrm{H}$ NMR $\left(500 \mathrm{MHz}, \mathrm{CD}_{2} \mathrm{Cl}_{2}\right) \delta 7.98(\mathrm{~d}, 2 \mathrm{H}, \mathrm{J}=8.5$ $\left.\mathrm{Hz}, \mathrm{H}_{3}\right), 6.94\left(\mathrm{~d}, 2 \mathrm{H}, \mathrm{J}=9.0 \mathrm{~Hz}, \mathrm{H}_{2}\right), 5.47\left(\mathrm{t}, \mathrm{J}=7.0 \mathrm{~Hz}, 1 \mathrm{H}, \mathrm{H}_{5}\right), 4.78\left(\mathrm{~d}, \mathrm{~J}=7.5 \mathrm{~Hz}, 2 \mathrm{H}, \mathrm{H}_{4}\right), 3.86(\mathrm{~s}, 3 \mathrm{H}$, $\left.\mathrm{H}_{1}\right), 1.80\left(\mathrm{~s}, 3 \mathrm{H}, \mathrm{H}_{7}\right), 1.78\left(\mathrm{~s}, 3 \mathrm{H}, \mathrm{H}_{8}\right) .{ }^{13} \mathrm{C} \mathrm{NMR}\left(125 \mathrm{MHz}, \mathrm{CD}_{2} \mathrm{Cl}_{2}\right) \delta 166.6(\mathrm{C}), 163.9(\mathrm{C}), 139.4(\mathrm{C})$, $131.9(\mathrm{CH}), 123.6(\mathrm{C}), 119.5(\mathrm{CH}), 114.1(\mathrm{CH}), 62.0\left(\mathrm{CH}_{2}\right), 56.0\left(\mathrm{CH}_{3}\right), 26.0\left(\mathrm{CH}_{3}\right), 18.4\left(\mathrm{CH}_{3}\right)$.

${ }^{1} \mathrm{H}$ and ${ }^{13} \mathrm{C}$ NMR data for 3-methylbut-2-en-1-yl 4-methoxybenzoate (1f) prepared in this way were in agreement with those previously described. ${ }^{10}$ 


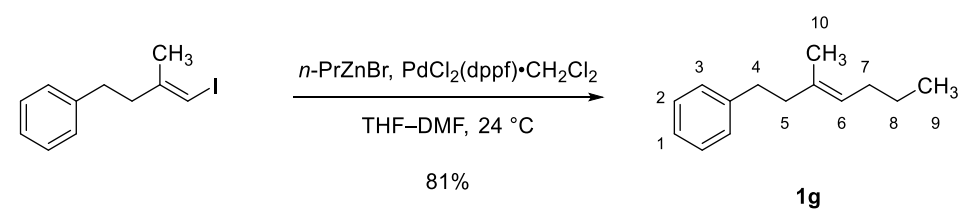

Preparation of (E)-(3-methylhept-2-en-1-yl)benzene (1g):

A 50-mL round-bottomed flask that had been fused to a Teflon-coated valve was charged with $(E)$ (4-iodo-3-methylbut-3-en-1-yl)benzene $\quad(272 \quad \mathrm{mg}, \quad 1.00 \quad \mathrm{mmol}, \quad 1$ equiv) and 1,1'bis(diphenylphosphino)ferrocene-palladium(II)dichloride dichloromethane complex (204 mg, $250 \mu \mathrm{mol}$, 0.25 equiv). The reaction vessel was evacuated and refilled using a balloon of argon. This process was repeated twice. $N, N$-Dimethylformamide $(20 \mathrm{~mL})$ was added to the reaction vessel. The reaction vessel was protected from light with aluminum foil. A solution of $n$-propylzinc bromide in tetrahydrofuran $(0.5$ $\mathrm{M}, 5.00 \mathrm{~mL}, 2.50 \mathrm{mmol}, 2.50$ equiv) was added to the reaction mixture via syringe. The reaction mixture was stirred for $18 \mathrm{~h}$ at $24{ }^{\circ} \mathrm{C}$. The product mixture was transferred to a separatory funnel that had been charged with ethyl acetate $(20 \mathrm{~mL})$ and ice-cold water $(10 \mathrm{~mL})$. The aqueous layer was isolated and the isolated aqueous layer was extracted with ethyl acetate $(3 \times 20 \mathrm{~mL})$. The organic layers were combined and the combined organic layers were dried over sodium sulfate. The dried solution was filtered and the filtrate was concentrated. The residue obtained was purified by automated flash-column chromatography (eluting with hexanes, isocratic) to afford (E)-(3-methylhept-2-en-1-yl)benzene (1g) as a volatile colorless oil (152 mg, 81\%).

$\mathrm{R}_{f}=0.88$ (hexanes; UV, CAM). ${ }^{1} \mathrm{H}$ NMR $\left(400 \mathrm{MHz}, \mathrm{CDCl}_{3}\right) \delta$ 7.29-7.25 (m, $\left.2 \mathrm{H}, \mathrm{H}_{2}\right), 7.18-7.15(\mathrm{~m}, 3 \mathrm{H}$, $\left.1 \times \mathrm{H}_{1}, 2 \times \mathrm{H}_{3}\right), 5.16-5.11\left(\mathrm{~m}, 1 \mathrm{H}, \mathrm{H}_{6}\right), 2.70\left(\mathrm{t}, \mathrm{J}=8.4 \mathrm{~Hz}, 2 \mathrm{H}, \mathrm{H}_{4}\right), 2.27\left(\mathrm{t}, \mathrm{J}=8.0 \mathrm{~Hz}, \mathrm{H}_{5}\right), 1.95(\mathrm{q}, \mathrm{J}=$ $\left.7.3 \mathrm{~Hz}, 2 \mathrm{H}, \mathrm{H}_{7}\right), 1.65\left(\mathrm{~s}, 3 \mathrm{H}, \mathrm{H}_{10}\right), 1.37-1.28\left(\mathrm{~m}, 2 \mathrm{H}, \mathrm{H}_{8}\right), 0.86\left(\mathrm{t}, \mathrm{J}=9.4 \mathrm{~Hz}, 3 \mathrm{H}, \mathrm{H}_{9}\right) .{ }^{13} \mathrm{C}$ NMR $(150 \mathrm{MHz}$, $\left.\mathrm{CDCl}_{3}\right) \delta 142.5(\mathrm{C}), 134.4(\mathrm{C}), 128.4(\mathrm{CH}), 128.2(\mathrm{CH}), 125.6(\mathrm{CH}), 125.1(\mathrm{CH}), 41.7\left(\mathrm{CH}_{2}\right), 34.8\left(\mathrm{CH}_{2}\right)$, $30.0\left(\mathrm{CH}_{2}\right), 22.9\left(\mathrm{CH}_{2}\right), 16.1\left(\mathrm{CH}_{3}\right), 13.8\left(\mathrm{CH}_{3}\right)$. IR (ATR-FTIR), $\mathrm{cm}^{-1}: 2957(\mathrm{~m}), 1454(\mathrm{w}), 887(\mathrm{w}), 743$ (w), 696 (s). HRMS-ESI (m/z): [M + Na] $]^{+}$calcd for $\mathrm{C}_{14} \mathrm{H}_{20} \mathrm{Na}, 211.1463$; found, 211.1464. 


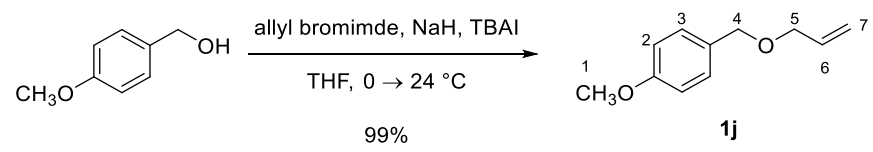

Preparation of 1-((allyloxy)methyl)-4-methoxybenzene (1j):

A $250-\mathrm{mL}$ round-bottomed flask that had been fused to a Teflon-coated valve was charged with sodium hydride (300 mg, $7.50 \mathrm{mmol}, 1.50$ equiv). The reaction vessel was evacuated and refilled using a balloon of argon. This process was repeated twice. Tetrahydrofuran $(24 \mathrm{~mL})$ was added to the reaction vessel via syringe and the resulting mixture was cooled to $0{ }^{\circ} \mathrm{C}$. A $250-\mathrm{mL}$ round-bottomed flask was charged with 4-methoxybenzyl alcohol $(691 \mathrm{mg}, 5.00 \mathrm{mmol}, 1$ equiv). The vessel containing the starting material was evacuated and refilled using a balloon of argon. This process was repeated twice. Tetrahydrofuran $(100 \mathrm{~mL})$ was added to the vessel containing the starting material and the resulting solution was transferred via cannula to the sodium hydride suspension. The reaction mixture was stirred at $0{ }^{\circ} \mathrm{C}$ for $45 \mathrm{~min}$. Tetrabutylammonium iodide $(92.3 \mathrm{mg}, 250 \mu \mathrm{mol}, 0.05$ equiv) and allyl bromide (786 $\mathrm{mg}$, $6.50 \mathrm{mmol}, 1.30$ equiv) were then added in sequence. The reaction mixture was allowed to warm over 30 min to $24{ }^{\circ} \mathrm{C}$. The warmed reaction mixture was stirred for $12 \mathrm{~h}$ at $24{ }^{\circ} \mathrm{C}$. The product mixture was filtered through a pad of silica gel and the pad was rinsed with ethyl acetate $(50 \mathrm{~mL})$. The filtrates were collected and combined and the combined filtrates were concentrated. The residue obtained was purified by automated flash-column chromatography (eluting with 5\% ether-hexanes initially, grading to $10 \%$ ether-hexanes, linear gradient) to afford 1-((allyloxy)methyl)-4-methoxybenzene (1j) as a light yellow oil (890 mg, 99\%).

$\mathrm{R}_{f}=0.39\left(20 \%\right.$ ether-hexanes; UV, $\left.\mathrm{KMnO}_{4}\right) .{ }^{1} \mathrm{H} \mathrm{NMR}\left(600 \mathrm{MHz}, \mathrm{CDCl}_{3}\right) \delta 7.27\left(\mathrm{~d}, 2 \mathrm{H}, \mathrm{J}=7.8 \mathrm{~Hz}, \mathrm{H}_{3}\right)$, $6.88\left(\mathrm{~d}, 2 \mathrm{H}, \mathrm{J}=7.2 \mathrm{~Hz}, \mathrm{H}_{2}\right), 5.94\left(\mathrm{ddt}, \mathrm{J}=16.8,10.2,5.4 \mathrm{~Hz}, 1 \mathrm{H}, \mathrm{H}_{6}\right), 5.29\left(\mathrm{~d}, \mathrm{~J}=16.8 \mathrm{~Hz}, 1 \mathrm{H}, \mathrm{H}_{7}\right), 5.19$ $\left(\mathrm{d}, \mathrm{J}=10.2 \mathrm{~Hz}, 1 \mathrm{H}, \mathrm{H}_{7}\right), 4.45\left(\mathrm{~s}, 2 \mathrm{H}, \mathrm{H}_{4}\right), 4.00\left(\mathrm{~d}, \mathrm{~J}=5.4 \mathrm{~Hz}, 2 \mathrm{H}, \mathrm{H}_{5}\right), 3.80\left(\mathrm{~s}, 3 \mathrm{H}, \mathrm{H}_{1}\right) .{ }^{13} \mathrm{C} \mathrm{NMR}(150$ $\left.\mathrm{MHz}, \mathrm{CDCl}_{3}\right) \delta 159.2(\mathrm{C}), 134.8(\mathrm{CH}), 130.3(\mathrm{C}), 129.3(\mathrm{CH}), 117.0\left(\mathrm{CH}_{2}\right), 113.7(\mathrm{CH}), 71.8\left(\mathrm{CH}_{2}\right), 70.8$ $\left(\mathrm{CH}_{2}\right), 55.2\left(\mathrm{CH}_{3}\right)$.

${ }^{1} \mathrm{H}$ and ${ }^{13} \mathrm{C}$ NMR data for 1-((allyloxy)methyl)-4-methoxybenzene (1j) prepared in this way were in agreement with those previously described. ${ }^{11}$ 

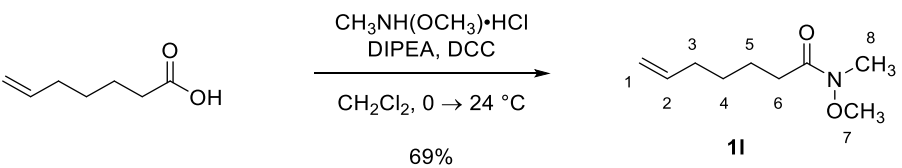

Preparation of $N$-methoxy- $N$-methylhept-6-enamide (11):

A 50-mL round-bottomed flask fitted with a rubber septum was charged with 6-heptenoic acid (385 $\mathrm{mg}, 3.00 \mathrm{mmol}, 1$ equiv) and $\mathrm{N}, O$-dimethylhydroxylamine hydrochloride ( $322 \mathrm{mg}, 3.30 \mathrm{mmol}, 1.10 \mathrm{equiv})$. The reaction vessel was evacuated and refilled using a balloon of argon. This process was repeated twice. Dichloromethane $(15 \mathrm{~mL})$ was added to the reaction vessel via syringe and the resulting mixture was cooled to $0{ }^{\circ} \mathrm{C}$. $\quad N, N$-Diisopropylethylamine $\left(818 \mu \mathrm{L}, 6.00 \mathrm{mmol}, 2.00\right.$ equiv) and $N, N^{\prime}$ dicyclohexylcarbodiimide (681 $\mathrm{mg}, 3.30 \mathrm{mmol}, 1.10$ equiv) were then added in sequence. The reaction mixture was stirred at $0{ }^{\circ} \mathrm{C}$ for $45 \mathrm{~min}$ and the ice bath was removed. The reaction mixture was stirred for $6 \mathrm{~h}$ at $24{ }^{\circ} \mathrm{C}$. The product mixture was transferred to a separatory funnel that had been charged with ethyl acetate $(20 \mathrm{~mL})$. The diluted product mixture was washed with saturated aqueous sodium bicarbonate solution $(20 \mathrm{~mL})$. The aqueous layer was isolated and the isolated aqueous layer was extracted with ethyl acetate $(3 \times 20 \mathrm{~mL})$. The organic layers were combined and the combined organic layers were dried over sodium sulfate. The dried solution was filtered and the filtrate was concentrated. The residue obtained was purified by automated flash-column chromatography (eluting with 5\% ethyl acetate-hexanes initially, grading to $50 \%$ ethyl acetate-hexanes, linear gradient) to afford $N$-methoxy- $N$-methylhept-6-enamide (11) as a colorless oil (356 mg, 69\%).

$\mathrm{R}_{f}=0.53$ (50\% ether-hexanes; $\left.\mathrm{KMnO}_{4}\right) .{ }^{1} \mathrm{H}$ NMR (400 MHz, $\left.\mathrm{CDCl}_{3}\right) \delta 5.83-5.76\left(\mathrm{~m}, 1 \mathrm{H}, \mathrm{H}_{2}\right), 5.01-4.91$ $\left(\mathrm{m}, 2 \mathrm{H}, \mathrm{H}_{1}\right), 3.66\left(\mathrm{~s}, 3 \mathrm{H}, \mathrm{H}_{7}\right), 3.16\left(\mathrm{~s}, 3 \mathrm{H}, \mathrm{H}_{8}\right), 2.41\left(\mathrm{t}, \mathrm{J}=7.8 \mathrm{~Hz}, 2 \mathrm{H}, \mathrm{H}_{6}\right), 2.09-2.04\left(\mathrm{~m}, 2 \mathrm{H}, \mathrm{H}_{3}\right), 1.66-$ $1.60\left(\mathrm{~m}, 2 \mathrm{H}, \mathrm{H}_{5}\right), 1.46-1.40\left(\mathrm{~m}, 2 \mathrm{H}, \mathrm{H}_{4}\right) .{ }^{13} \mathrm{C} \mathrm{NMR}\left(125 \mathrm{MHz}, \mathrm{CDCl}_{3}\right) \delta 174.0(\mathrm{C}), 138.6(\mathrm{CH}), 114.5$ $\left(\mathrm{CH}_{2}\right), 61.2\left(\mathrm{CH}_{3}\right), 33.5\left(\mathrm{CH}_{2}\right), 32.1\left(\mathrm{CH}_{3}\right), 31.7\left(\mathrm{CH}_{2}\right), 28.6\left(\mathrm{CH}_{2}\right), 24.1\left(\mathrm{CH}_{2}\right)$.

${ }^{1} \mathrm{H}$ and ${ }^{13} \mathrm{C}$ NMR data for $N$-methoxy- $N$-methylhept-6-enamide (11) prepared in this way were in agreement with those previously described. ${ }^{12}$ 


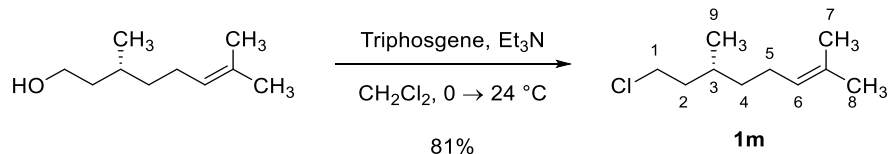

Preparation of $(R)$-citronellyl chloride $(1 \mathrm{~m})$ :

A $100-\mathrm{mL}$ round-bottomed flask fitted with a rubber septum was charged with $(R)$-citronellol (936 $\mathrm{mg}, 6.00 \mathrm{mmol}, 1$ equiv). The reaction vessel was evacuated and refilled using a balloon of argon. This process was repeated twice. Dichloromethane $(45 \mathrm{~mL})$ was added to the reaction vessel via syringe and the resulting mixture was cooled to $0{ }^{\circ} \mathrm{C}$. Triethylamine $(2.09 \mathrm{~mL}, 15.0 \mathrm{mmol}, 2.50$ equiv) and triphosgene (890 mg, $3.00 \mathrm{mmol}, 0.500$ equiv) were then added in sequence. The reaction mixture was stirred at $0{ }^{\circ} \mathrm{C}$ for $45 \mathrm{~min}$ and the ice bath was removed. The reaction mixture was stirred for $2 \mathrm{~h}$ at $24{ }^{\circ} \mathrm{C}$. The product mixture was transferred to a separatory funnel that had been charged with ethyl acetate $(20 \mathrm{~mL})$. The diluted product mixture was washed with saturated aqueous sodium bicarbonate solution $(20 \mathrm{~mL})$. The aqueous layer was isolated and the isolated aqueous layer was extracted with ethyl acetate $(3 \times 20 \mathrm{~mL})$. The organic layers were combined and the combined organic layers were dried over sodium sulfate. The dried solution was filtered and the filtrate was concentrated. The residue obtained was purified by automated flash-column chromatography (eluting with hexanes) to afford $(R)$-citronelly chloride $(\mathbf{1 m})$ as a colorless oil (849 mg, 81\%).

$\mathrm{R}_{f}=0.67$ (hexanes; $\left.\mathrm{KMnO}_{4}\right) .{ }^{1} \mathrm{H}$ NMR $\left(400 \mathrm{MHz}, \mathrm{CDCl}_{3}\right) \delta 5.09\left(\mathrm{t}, \mathrm{J}=7.0 \mathrm{~Hz}, 1 \mathrm{H}, \mathrm{H}_{6}\right), 3.61-3.49(\mathrm{~m}, 2 \mathrm{H}$, $\left.\mathrm{H}_{1}\right), 2.06-1.91\left(\mathrm{~m}, 2 \mathrm{H}, \mathrm{H}_{5}\right), 1.84-1.76\left(\mathrm{~m}, 1 \mathrm{H}, 1 \times \mathrm{H}_{4}\right), 1.68-1.52\left(\mathrm{~m}, 8 \mathrm{H}, 1 \times \mathrm{H}_{4}, 1 \times \mathrm{H}_{3}, 3 \times \mathrm{H}_{7}, 3 \times \mathrm{H}_{8}\right)$, $1.39-1.30\left(\mathrm{~m}, 1 \mathrm{H}, \mathrm{H}_{2}\right), 1.22-1.13\left(\mathrm{~m}, 1 \mathrm{H}, \mathrm{H}_{2}\right), 0.90\left(\mathrm{~d}, \mathrm{~J}=6.8 \mathrm{~Hz}, 3 \mathrm{H}, \mathrm{H}_{9}\right) .{ }^{13} \mathrm{C} \mathrm{NMR}\left(100 \mathrm{MHz}, \mathrm{CDCl}_{3}\right) \delta$ $131.4(\mathrm{C}), 124.4(\mathrm{CH}), 43.2\left(\mathrm{CH}_{2}\right), 39.7\left(\mathrm{CH}_{2}\right), 36.7\left(\mathrm{CH}_{2}\right), 30.1(\mathrm{CH}), 25.7\left(\mathrm{CH}_{3}\right), 25.3\left(\mathrm{CH}_{2}\right), 18.9\left(\mathrm{CH}_{3}\right)$, $17.6\left(\mathrm{CH}_{3}\right)$.

${ }^{1} \mathrm{H}$ and ${ }^{13} \mathrm{C}$ NMR data for $(R)$-citronelly chloride (1m) prepared in this way were in agreement with those previously described. ${ }^{13}$ 


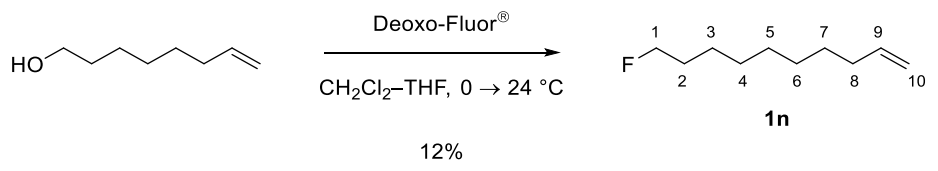

Preparation of 10-fluorodec-1-en (1n):

A 20-mL teflon vial fitted with a rubber septum was charged with 9-decen-1-ol (1.42 g, $8.00 \mathrm{mmol}$, 1 equiv). The reaction vessel was evacuated and refilled using a balloon of argon. This process was repeated twice. Dichloromethane $(2.5 \mathrm{~mL})$ and tetrahydrofuran $(2.5 \mathrm{~mL})$ were added to the reaction vessel via syringe and the resulting mixture was cooled to $0{ }^{\circ} \mathrm{C}$. Deoxo-Fluor ${ }^{\circledR}(2.95 \mathrm{~mL}, 16.0 \mathrm{mmol}, 2.00$ equiv) was added into the reaction vessel via syringe. The reaction mixture was stirred at $0{ }^{\circ} \mathrm{C}$ for $45 \mathrm{~min}$ and the ice bath was removed. The reaction mixture was stirred for $2 \mathrm{~h}$ at $24{ }^{\circ} \mathrm{C}$. The product mixture was transferred to a separatory funnel that had been charged with ethyl acetate $(20 \mathrm{~mL})$. The diluted product mixture was washed with saturated aqueous sodium bicarbonate solution $(20 \mathrm{~mL})$. The aqueous layer was isolated and the isolated aqueous layer was extracted with ethyl acetate $(3 \times 20 \mathrm{~mL})$. The organic layers were combined and the combined organic layers were dried over sodium sulfate. The dried solution was filtered and the filtrate was concentrated. The residue obtained was purified by automated flash-column chromatography (eluting with hexanes) to afford 10-fluorodec-1-ene (1n) as a colorless oil (156 mg, 12\%).

$\mathrm{R}_{f}=0.46$ (hexanes; $\mathrm{KMnO}_{4}$ ). ${ }^{1} \mathrm{H}$ NMR $\left(400 \mathrm{MHz}, \mathrm{CDCl}_{3}\right) \delta 5.86-5.75\left(\mathrm{~m}, 1 \mathrm{H}, \mathrm{H}_{9}\right), 5.01-4.91(\mathrm{~m}, 2 \mathrm{H}$, $\left.\mathrm{H}_{10}\right), 4.43\left(\mathrm{dt}, \mathrm{J}(\mathrm{H}, \mathrm{F})=47.4, \mathrm{~J}(\mathrm{H}, \mathrm{H})=6.2 \mathrm{~Hz}, 2 \mathrm{H}, \mathrm{H}_{1}\right), 2.10-1.99\left(\mathrm{~m}, 2 \mathrm{H}, \mathrm{H}_{8}\right), 1.74-1.55\left(\mathrm{~m}, 2 \mathrm{H}, \mathrm{H}_{2}\right)$, 1.45-1.24 (m, 10H, $\left.2 \times \mathrm{H}_{3}, 2 \times \mathrm{H}_{4}, 2 \times \mathrm{H}_{5}, 2 \times \mathrm{H}_{6}, 2 \times \mathrm{H}_{7}\right) .{ }^{19} \mathrm{~F} \mathrm{NMR}\left(375 \mathrm{MHz}, \mathrm{CDCl}_{3}\right) \delta-218.1$.

${ }^{1} \mathrm{H}$ and ${ }^{19} \mathrm{~F}$ NMR data for 10 -fluorodec-1-ene (1n) prepared in this way were in agreement with those previously described. ${ }^{14}$ 


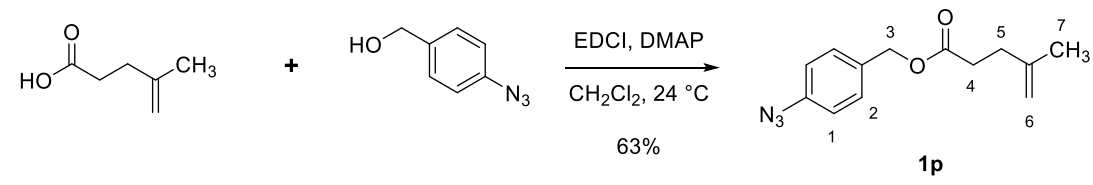

Preparation of 4-azidobenzyl 4-methylpent-4-enoate (1p):

A 50-mL round-bottomed flask fitted with a rubber septum was charged with 4-azidobenzyl alcohol (448 mg, $3.00 \mathrm{mmol}, 1$ equiv) and 4-methylpent-4-enoic acid (936 mg, $4.50 \mathrm{mmol}, 1.50$ equiv). The reaction vessel was evacuated and refilled using a balloon of argon. This process was repeated twice. Dichloromethane $(15 \mathrm{~mL})$ was added to the reaction vessel via syringe. $N$-(3-Dimethylaminopropyl)- $N$ 'ethylcarbodiimide hydrochloride $(863 \mathrm{mg}, 4.50 \mathrm{mmol}, 1.50$ equiv) and 4-dimethylaminopyridine ( $36.7 \mathrm{mg}$, 0.300 mmol, 0.100 equiv) were then added in sequence. The reaction mixture was stirred for $2 \mathrm{~h}$ at $24^{\circ} \mathrm{C}$. The product mixture was transferred to a separatory funnel that had been charged with ethyl acetate (20 $\mathrm{mL})$. The diluted product mixture was washed with saturated aqueous ammonium chloride solution (20 $\mathrm{mL})$. The aqueous layer was isolated and the isolated aqueous layer was extracted with ethyl acetate $(3 \times$ $20 \mathrm{~mL}$ ). The organic layers were combined and the combined organic layers were dried over sodium sulfate. The dried solution was filtered and the filtrate was concentrated. The residue obtained was purified by flash-column chromatography (eluting with hexanes initially, grading to $50 \%$ ethyl acetatehexanes, linear gradient) to afford 4-azidobenzyl 4-methylpent-4-enoate (1p) as a light yellow oil (465 mg, $63 \%)$.

$\mathrm{R}_{f}=0.88$ (hexanes; UV, CAM). ${ }^{1} \mathrm{H}$ NMR $\left(500 \mathrm{MHz}, \mathrm{CDCl}_{3}\right) \delta 7.34\left(\mathrm{~d}, \mathrm{~J}=8.0 \mathrm{~Hz}, 2 \mathrm{H}, \mathrm{H}_{1}\right), 7.01(\mathrm{~d}, \mathrm{~J}=$ $\left.8.0 \mathrm{~Hz}, 2 \mathrm{H}, \mathrm{H}_{2}\right), 5.08\left(\mathrm{~s}, 2 \mathrm{H}, \mathrm{H}_{3}\right), 4.74\left(\mathrm{~s}, 1 \mathrm{H}, 1 \times \mathrm{H}_{6}\right), 4.67\left(\mathrm{~s}, 1 \mathrm{H}, 1 \times \mathrm{H}_{6}\right), 2.50\left(\mathrm{t}, \mathrm{J}=7.5 \mathrm{~Hz}, 2 \mathrm{H}, \mathrm{H}_{4}\right)$, $2.34\left(\mathrm{t}, \mathrm{J}=7.5 \mathrm{~Hz}, 2 \mathrm{H}, \mathrm{H}_{5}\right), 1.73\left(\mathrm{~s}, 3 \mathrm{H}, \mathrm{H}_{7}\right) .{ }^{13} \mathrm{C} \mathrm{NMR}\left(150 \mathrm{MHz}, \mathrm{CDCl}_{3}\right) \delta 173.0(\mathrm{C}), 143.9(\mathrm{C}), 140.0$ (C), $132.8(\mathrm{C}), 129.9(\mathrm{CH}), 119.1(\mathrm{CH}), 110.4\left(\mathrm{CH}_{2}\right), 65.6\left(\mathrm{CH}_{2}\right), 32.6\left(\mathrm{CH}_{2}\right), 32.5\left(\mathrm{CH}_{2}\right), 22.5\left(\mathrm{CH}_{3}\right)$. IR (ATR-FTIR), $\mathrm{cm}^{-1}: 2939$ (w), 2416 (w), 1108 (s), 1733 (s), 1597 (s), 1446 (m), 1282 (m), 1147 (s), 1128 (s), $813(\mathrm{~m})$. HRMS-ESI (m/z): [M + Na $]^{+}$calcd for $\mathrm{C}_{13} \mathrm{H}_{15} \mathrm{NaN}_{3} \mathrm{O}_{4}, 268.1062$; found, 268.1073. 


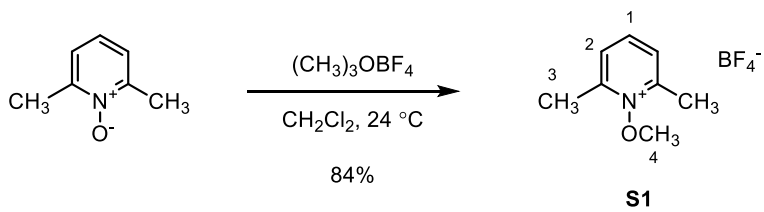

Preparation of N-methoxy 2,6-lutidinium tetrafluoroborate (S1):

A $25-\mathrm{mL}$ round-bottomed flask fitted with a rubber septum was charged with 2,6-lutidine $N$-oxide (616 mg, $5.00 \mathrm{mmol}, 1$ equiv). The reaction vessel was evacuated and refilled using a balloon of argon. This process was repeated twice. Dichloromethane $(10 \mathrm{~mL})$ was added to the reaction vessel via syringe. Trimethyloxonium tetrafluoroborate $(738 \mathrm{mg}, 5.00 \mathrm{mmol}, 1.00$ equiv) was added to the reaction vessel in one portion. The reaction mixture was stirred for $4 \mathrm{~h}$ at $24{ }^{\circ} \mathrm{C}$. The product mixture was concentrated to dryness and the residue obtained was purified by recrystallization from anhydrous acetone under an atmosphere of argon to afford $\mathrm{N}$-methoxy 2,6-lutidinium tetrafluoroborate (S1) as colorless needles (944 $\mathrm{mg}, 84 \%)$.

${ }^{1} \mathrm{H}$ NMR $\left(400 \mathrm{MHz},\left(\mathrm{CD}_{3}\right)_{2} \mathrm{SO}\right) \delta 8.34\left(\mathrm{t}, \mathrm{J}=7.8 \mathrm{~Hz}, 1 \mathrm{H}, \mathrm{H}_{1}\right), 7.94\left(\mathrm{~d}, \mathrm{~J}=7.4 \mathrm{~Hz}, 2 \mathrm{H}, \mathrm{H}_{2}\right), 4.28(\mathrm{~s}, 3 \mathrm{H}$, $\left.\mathrm{H}_{4}\right), 2.82\left(\mathrm{~s}, 6 \mathrm{H} \mathrm{H}_{3}\right) .{ }^{13} \mathrm{C}$ NMR $\left(150 \mathrm{MHz},\left(\mathrm{CD}_{3}\right)_{2} \mathrm{SO}\right) \delta 153.8(\mathrm{C}), 144.3(\mathrm{CH}), 128.4(\mathrm{CH}), 67.4\left(\mathrm{CH}_{3}\right)$, 17.4 $\left(\mathrm{CH}_{3}\right) .{ }^{19} \mathrm{~F}$ NMR (375 MHz, $\left.\left(\mathrm{CD}_{3}\right)_{2} \mathrm{SO}\right) \delta-148.4$. IR (ATR-FTIR), $\mathrm{cm}^{-1}: 1621(\mathrm{~m}) .1501(\mathrm{~m}), 1093$ (m), 1030 (s), 944 (s). HRMS-ESI (m/z): $\left[\mathrm{M}-\mathrm{BF}_{4}\right]^{+}$calcd for $\mathrm{C}_{8} \mathrm{H}_{12} \mathrm{NO}, 138.0913$; found, 138.0913 . 


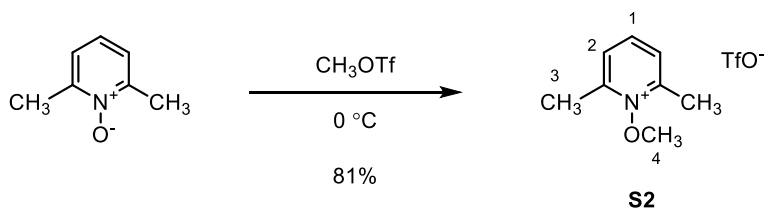

Preparation of N-methoxy 2,6-lutidinium triflate (S2):

A 25-mL round-bottomed flask fitted with a rubber septum was charged with 2,6-lutidine $N$-oxide $(1.23 \mathrm{~g}, 10.0 \mathrm{mmol}, 1$ equiv). The reaction vessel was evacuated and refilled using a balloon of argon. This process was repeated twice. The reaction vessel was then cooled to $0{ }^{\circ} \mathrm{C}$. Methyl triflate $(870 \mu \mathrm{L}$, $10.0 \mathrm{mmol}, 1.00$ equiv) was added to the reaction vessel dropwise via syringe over $30 \mathrm{~min}$. The reaction mixture was stirred for $4 \mathrm{~h}$ at $0{ }^{\circ} \mathrm{C}$. The product mixture was concentrated to dryness and the residue obtained was purified by recrystallization from anhydrous acetone under an atmosphere of argon to afford $N$-methoxy 2,6-lutidinium triflate (S2) as colorless needles (2.32 g, 81\%).

${ }^{1} \mathrm{H}$ NMR $\left(400 \mathrm{MHz},\left(\mathrm{CD}_{3}\right)_{2} \mathrm{SO}\right) \delta 8.35\left(\mathrm{t}, \mathrm{J}=7.8 \mathrm{~Hz}, 1 \mathrm{H}, \mathrm{H}_{1}\right), 7.95\left(\mathrm{~d}, \mathrm{~J}=7.4 \mathrm{~Hz}, 2 \mathrm{H}, \mathrm{H}_{2}\right), 4.29\left(\mathrm{~s}, 3 \mathrm{H}, \mathrm{H}_{4}\right)$, $2.82\left(\mathrm{~s}, 6 \mathrm{H}, \mathrm{H}_{3}\right) .{ }^{13} \mathrm{C}$ NMR $\left(100 \mathrm{MHz},\left(\mathrm{CD}_{3}\right)_{2} \mathrm{SO}\right) \delta 153.8(\mathrm{C}), 144.3(\mathrm{CH}), 128.5(\mathrm{CH}), 125.1(\mathrm{q}, \mathrm{J}=227$ $\mathrm{Hz}, \mathrm{C}), 67.4\left(\mathrm{CH}_{3}\right), 17.4\left(\mathrm{CH}_{3}\right) .{ }^{19} \mathrm{~F}$ NMR $\left(375 \mathrm{MHz}, \mathrm{CDCl}_{3}\right) \delta-77.8$. IR (ATR-FTIR), $\mathrm{cm}^{-1}: 3070(\mathrm{w})$, 1619 (w), 1497 (w), 1254 (s), $1148(\mathrm{~s}), 1028$ (s), 949 (m). HRMS-ESI (m/z): [M - $\left.\mathrm{CF}_{3} \mathrm{SO}_{3}^{-}\right]^{+}$calcd for $\mathrm{C}_{8} \mathrm{H}_{12} \mathrm{NO}, 138.0913$; found, 138.0904 . 

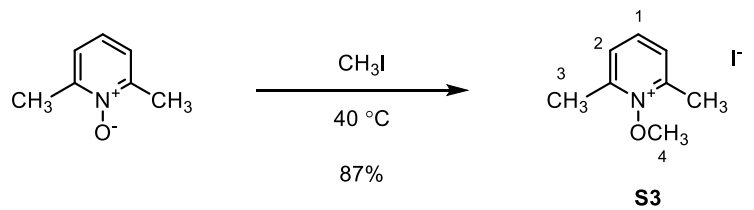

Preparation of $\mathrm{N}$-methoxy 2,6-lutidinium iodide (S3):

A $25-\mathrm{mL}$ two-neck round-bottomed flask equipped with a reflux condenser was charged with 2,6lutidine $N$-oxide $(1.23 \mathrm{~g}, 10.0 \mathrm{mmol}, 1$ equiv). The reaction vessel was evacuated and refilled using a balloon of argon. This process was repeated twice. The reaction vessel was then cooled to $0{ }^{\circ} \mathrm{C}$. Methyl iodide ( $622 \mu \mathrm{L}, 10.0 \mathrm{mmol}, 1.00$ equiv) was added to the reaction vessel dropwise via syringe over $5 \mathrm{~min}$. The reaction vessel was placed in an oil bath that had been preheated to $40{ }^{\circ} \mathrm{C}$. The reaction mixture was stirred for $4 \mathrm{~h}$ at $40{ }^{\circ} \mathrm{C}$. The product mixture was concentrated to dryness and the residue obtained was purified by recrystallization from a mixture of anhydrous acetone, acetonitrile, and chloroform ( 5:4:1) under an atmosphere of argon to afford $N$-methoxy 2,6-lutidinium iodide (S3) as white powder (2.32 g, $87 \%)$.

${ }^{1} \mathrm{H} \mathrm{NMR}\left(400 \mathrm{MHz},\left(\mathrm{CD}_{3}\right)_{2} \mathrm{SO}\right) \delta 8.38\left(\mathrm{t}, \mathrm{J}=7.8 \mathrm{~Hz}, 1 \mathrm{H}, \mathrm{H}_{1}\right), 7.99\left(\mathrm{~d}, \mathrm{~J}=7.4 \mathrm{~Hz}, 2 \mathrm{H}, \mathrm{H}_{2}\right), 4.29\left(\mathrm{~s}, 3 \mathrm{H}, \mathrm{H}_{4}\right)$, $2.83\left(\mathrm{~s}, 6 \mathrm{H} \mathrm{H}_{3}\right) .{ }^{13} \mathrm{C} \mathrm{NMR}\left(100 \mathrm{MHz},\left(\mathrm{CD}_{3}\right)_{2} \mathrm{SO}\right) \delta 153.7(\mathrm{C}), 144.4(\mathrm{CH}), 128.5(\mathrm{CH}), 67.6\left(\mathrm{CH}_{3}\right), 17.7$ $\left(\mathrm{CH}_{3}\right)$. IR (ATR-FTIR), $\mathrm{cm}^{-1}$ : $3031(\mathrm{w}), 1618(\mathrm{~m}), 1498(\mathrm{~m}), 942(\mathrm{~m}), 619(\mathrm{~s})$. HRMS-ESI (m/z): [M - I'] ${ }^{+}$ calcd for $\mathrm{C}_{8} \mathrm{H}_{12} \mathrm{NO}, 138.0913$; found, 138.0914. 

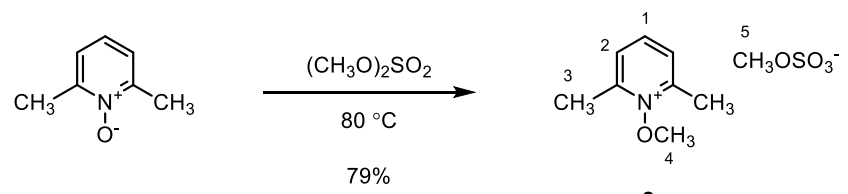

$2 \mathbf{a}$

Preparation of N-methoxy 2,6-lutidinium methylsulfate (2a):

A $25-\mathrm{mL}$ round-bottomed flask fitted with a rubber septum was charged with 2,6-lutidine $N$-oxide $(2.81 \mathrm{~g}, 22.8 \mathrm{mmol}, 1$ equiv). The reaction vessel was evacuated and refilled using a balloon of argon. This process was repeated twice. The reaction vessel was then cooled to $0{ }^{\circ} \mathrm{C}$. Dimethylsulfate $(2.16 \mathrm{~mL}$, $22.8 \mathrm{mmol}, 1.00$ equiv) was added to the reaction vessel dropwise via syringe over $5 \mathrm{~min}$. The reaction vessel was placed in an oil bath that had been preheated to $80{ }^{\circ} \mathrm{C}$. The reaction mixture was stirred and heated for $3 \mathrm{~h}$ at $80{ }^{\circ} \mathrm{C}$. The product mixture was concentrated to dryness and the residue obtained was purified by recrystallization from anhydrous acetone under an atmosphere of argon to afford $N$-methoxy 2,6-lutidinium methylsulfate (2a) as colorless needles (4.51 g, 79\%).

${ }^{1} \mathrm{H}$ NMR $\left(400 \mathrm{MHz}, \mathrm{CDCl}_{3}\right) \delta 8.25\left(\mathrm{t}, \mathrm{J}=7.8 \mathrm{~Hz}, 1 \mathrm{H}, \mathrm{H}_{1}\right), 7.85\left(\mathrm{~d}, \mathrm{~J}=7.4 \mathrm{~Hz}, 2 \mathrm{H}, \mathrm{H}_{2}\right), 4.36\left(\mathrm{~s}, 3 \mathrm{H}, \mathrm{H}_{4}\right)$, $3.51\left(\mathrm{~s}, 3 \mathrm{H}, \mathrm{H}_{5}\right), 2.88\left(\mathrm{~s}, 6 \mathrm{H} \mathrm{H}_{3}\right) .{ }^{13} \mathrm{C} \mathrm{NMR}\left(100 \mathrm{MHz}, \mathrm{CDCl}_{3}\right) \delta 153.2(\mathrm{C}), 144.3(\mathrm{CH}), 128.8(\mathrm{CH}), 67.3$ $\left(\mathrm{CH}_{3}\right), 54.1\left(\mathrm{CH}_{3}\right), 17.7\left(\mathrm{CH}_{3}\right)$. IR (ATR-FTIR), cm ${ }^{-1}: 3051(\mathrm{w}), 1615(\mathrm{~m}), 1495(\mathrm{~m}), 1214(\mathrm{~s}), 1172(\mathrm{~s})$, 1005 (s), 736 (s). HRMS-ESI (m/z): [M- $\left.\mathrm{CH}_{3} \mathrm{OSO}_{3}\right]^{+}$calcd for $\mathrm{C}_{8} \mathrm{H}_{12} \mathrm{NO}, 138.0913$; found, 138.0913. 


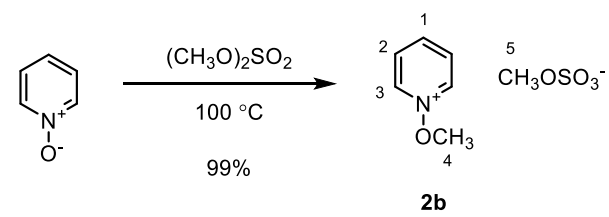

Preparation of $N$-methoxy pyridinium methylsulfate $(\mathbf{2 b})$ :

A $25-\mathrm{mL}$ round-bottomed flask fitted with a rubber septum was charged with pyridine $N$-oxide (2.17 g, $22.8 \mathrm{mmol}, 1$ equiv). The reaction vessel was evacuated and refilled using a balloon of argon. This process was repeated twice. The reaction vessel was then cooled to $0{ }^{\circ} \mathrm{C}$. Dimethylsulfate $(2.16 \mathrm{~mL}$, $22.8 \mathrm{mmol}, 1.00$ equiv) was added to the reaction vessel dropwise via syringe over $5 \mathrm{~min}$. The reaction vessel was placed in an oil bath that had been preheated to $100{ }^{\circ} \mathrm{C}$. The reaction mixture was stirred and heated for $5 \mathrm{~h}$ at $100{ }^{\circ} \mathrm{C}$. The product mixture was concentrated in vacuo $(0.1$ Torr $)$ overnight to afford $\mathrm{N}$ methoxy pyridinium methylsulfate (2b) as a colorless low-melting solid (4.99 g, 99\%).

${ }^{1} \mathrm{H}$ NMR (400 MHz, $\left.\left(\mathrm{CD}_{3}\right)_{2} \mathrm{SO}\right) \delta 9.44\left(\mathrm{~d}, \mathrm{~J}=6.8 \mathrm{~Hz}, 2 \mathrm{H}, \mathrm{H}_{3}\right), 8.61\left(\mathrm{t}, \mathrm{J}=8.0 \mathrm{~Hz}, 1 \mathrm{H}, \mathrm{H}_{1}\right), 8.23(\mathrm{t}, \mathrm{J}=7.2$ $\left.\mathrm{Hz}, 2 \mathrm{H}, \mathrm{H}_{2}\right), 4.42\left(\mathrm{~s}, 3 \mathrm{H}, \mathrm{H}_{4}\right), 3.37\left(\mathrm{~s}, 3 \mathrm{H}, \mathrm{H}_{5}\right) .{ }^{13} \mathrm{C} \mathrm{NMR}\left(100 \mathrm{MHz},\left(\mathrm{CD}_{3}\right)_{2} \mathrm{SO}\right) \delta 145.5(\mathrm{CH}), 141.3(\mathrm{CH})$, $129.8(\mathrm{CH}), 69.9\left(\mathrm{CH}_{3}\right), 53.4\left(\mathrm{CH}_{3}\right)$. IR (ATR-FTIR), $\mathrm{cm}^{-1}: 3041(\mathrm{w}), 1479(\mathrm{~m}), 1220(\mathrm{~s}), 1001(\mathrm{~s}), 730(\mathrm{~s})$, $668(\mathrm{~m}), 576(\mathrm{~s})$. HRMS-ESI (m/z): $\left[\mathrm{M}-\mathrm{CH}_{3} \mathrm{OSO}_{3}\right]^{+}$calcd for $\mathrm{C}_{6} \mathrm{H}_{8} \mathrm{NO}, 110.0600$; found, 110.0604 . 


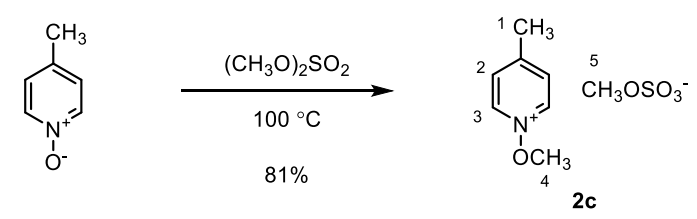

Preparation of $N$-methoxy 4-picolinium methylsulfate (2c):

A $25-\mathrm{mL}$ round-bottomed flask fitted with a rubber septum was charged with 4-picoline $N$-oxide (2.49 g, $22.8 \mathrm{mmol}, 1$ equiv). The reaction vessel was evacuated and refilled using a balloon of argon. This process was repeated twice. The reaction vessel was then cooled to $0{ }^{\circ} \mathrm{C}$. Dimethylsulfate $(2.16 \mathrm{~mL}$, $22.8 \mathrm{mmol}, 1.00$ equiv) was added to the reaction vessel dropwise via syringe over $5 \mathrm{~min}$. The reaction vessel was placed in an oil bath that had been preheated to $100{ }^{\circ} \mathrm{C}$. The reaction mixture was stirred and heated for $2 \mathrm{~h}$ at $100{ }^{\circ} \mathrm{C}$. The product mixture was concentrated to dryness and the residue obtained was purified by recrystallization from anhydrous acetone under an atmosphere of argon to afford $\mathrm{N}$-methoxy 4picolinium methylsulfate (2c) as colorless needles $(4.33 \mathrm{~g}, 81 \%)$.

${ }^{1} \mathrm{H}$ NMR $\left(400 \mathrm{MHz}, \mathrm{CDCl}_{3}\right) \delta 9.26\left(\mathrm{~d}, \mathrm{~J}=6.8 \mathrm{~Hz}, 2 \mathrm{H}, \mathrm{H}_{3}\right), 7.78\left(\mathrm{~d}, \mathrm{~J}=6.8 \mathrm{~Hz}, 2 \mathrm{H}, \mathrm{H}_{2}\right), 4.45\left(\mathrm{~s}, 3 \mathrm{H}, \mathrm{H}_{4}\right)$, $3.65\left(\mathrm{~s}, 3 \mathrm{H}, \mathrm{H}_{5}\right), 2.64\left(\mathrm{~s}, 3 \mathrm{H} \mathrm{H}_{1}\right) .{ }^{13} \mathrm{C} \mathrm{NMR}\left(100 \mathrm{MHz}, \mathrm{CDCl}_{3}\right) \delta 158.7(\mathrm{C}), 140.2(\mathrm{CH}), 130.2(\mathrm{CH}), 69.8$ $\left(\mathrm{CH}_{3}\right), 54.3\left(\mathrm{CH}_{3}\right), 22.1\left(\mathrm{CH}_{3}\right)$. IR (ATR-FTIR), $\mathrm{cm}^{-1}: 3116(\mathrm{w}), 1627(\mathrm{w}), 1243(\mathrm{~s}), 1218(\mathrm{~s}), 1005(\mathrm{~s}), 738$ (s), $578(\mathrm{~m})$. HRMS-ESI (m/z): $\left[\mathrm{M}-\mathrm{CH}_{3} \mathrm{OSO}_{3}\right]^{+}$calcd for $\mathrm{C}_{7} \mathrm{H}_{10} \mathrm{NO}, 124.0757$; found, 124.0759 . 


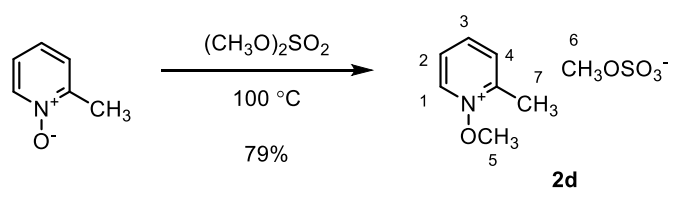

Preparation of $N$-methoxy 2-picolinium methylsulfate (2d):

A $25-\mathrm{mL}$ round-bottomed flask fitted with a rubber septum was charged with 2-picoline $\mathrm{N}$-oxide (2.49 g, $22.8 \mathrm{mmol}, 1$ equiv). The reaction vessel was evacuated and refilled using a balloon of argon. This process was repeated twice. The reaction vessel was then cooled to $0{ }^{\circ} \mathrm{C}$. Dimethylsulfate $(2.16 \mathrm{~mL}$, $22.8 \mathrm{mmol}, 1.00$ equiv) was added to the reaction vessel dropwise via syringe over $5 \mathrm{~min}$. The reaction vessel was placed in an oil bath that had been preheated to $100{ }^{\circ} \mathrm{C}$. The reaction mixture was stirred and heated for $2 \mathrm{~h}$ at $100{ }^{\circ} \mathrm{C}$. The product mixture was concentrated to dryness and the residue obtained was purified by recrystallization from anhydrous acetone under an atmosphere of argon to afford $\mathrm{N}$-methoxy 2picolinium methylsulfate (2d) as colorless needles $(4.23 \mathrm{~g}, 79 \%)$.

${ }^{1} \mathrm{H} \mathrm{NMR}\left(400 \mathrm{MHz}, \mathrm{CDCl}_{3}\right) \delta 9.39\left(\mathrm{~d}, \mathrm{~J}=8.4 \mathrm{~Hz}, 1 \mathrm{H}, \mathrm{H}_{1}\right), 8.40\left(\mathrm{t}, \mathrm{J}=8.4 \mathrm{~Hz}, 1 \mathrm{H}, \mathrm{H}_{3}\right), 8.04-8.00(\mathrm{~m}, 2 \mathrm{H}$, $\left.1 \times \mathrm{H}_{2}, 1 \times \mathrm{H}_{4}\right), 4.43\left(\mathrm{~s}, 3 \mathrm{H}, \mathrm{H}_{5}\right), 3.56\left(\mathrm{~s}, 3 \mathrm{H}, \mathrm{H}_{6}\right), 2.85\left(\mathrm{~s}, 3 \mathrm{H}, \mathrm{H}_{7}\right) .{ }^{13} \mathrm{C} \mathrm{NMR}\left(100 \mathrm{MHz}, \mathrm{CDCl}_{3}\right) \delta 152.6$ (C), $144.9(\mathrm{CH}), 141.2(\mathrm{CH}), 130.7(\mathrm{CH}), 127.9(\mathrm{CH}), 68.8\left(\mathrm{CH}_{3}\right), 54.2\left(\mathrm{CH}_{3}\right), 17.3\left(\mathrm{CH}_{3}\right)$. IR (ATR-FTIR), $\mathrm{cm}^{-1}$ : 3043 (w), 1622 (w), 1243 (s), 1213 (s), 1003 (s), 736 (s), 608 (m). HRMS-ESI (m/z): [M $\left.\mathrm{CH}_{3} \mathrm{OSO}_{3}^{-}\right]^{+}$calcd for $\mathrm{C}_{7} \mathrm{H}_{10} \mathrm{NO}, 124.0757$; found, 124.0760 . 


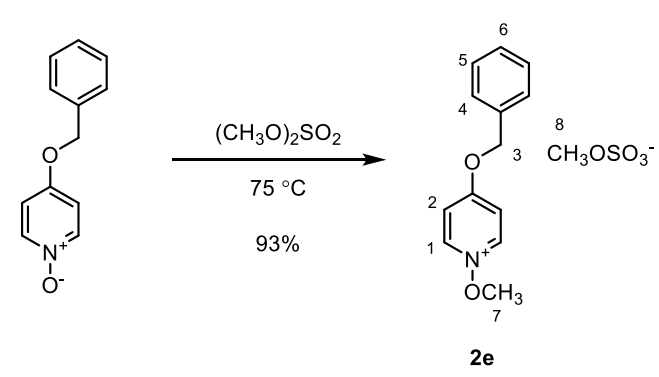

Preparation of $N$-methoxy 4-benzyloxypyridinium methylsulfate (2e):

A $25-\mathrm{mL}$ round-bottomed flask fitted with a rubber septum was charged with 4-benzyloxypyridine $\mathrm{N}$-oxide ( $2.01 \mathrm{~g}, 10.0 \mathrm{mmol}, 1$ equiv). The reaction vessel was evacuated and refilled using a balloon of argon. This process was repeated twice. The reaction vessel was then cooled to $0{ }^{\circ} \mathrm{C}$. Dimethylsulfate (1.26 mL, $10.0 \mathrm{mmol}, 1.00$ equiv) was added to the reaction vessel dropwise via syringe over $5 \mathrm{~min}$. The reaction vessel was placed in an oil bath that had been preheated to $75^{\circ} \mathrm{C}$. The reaction mixture was stirred and heated for $3 \mathrm{~h}$ at $75^{\circ} \mathrm{C}$. The product mixture was concentrated in vacuo $(0.1$ Torr $)$ overnight to afford $\mathrm{N}$-methoxy 4-benzyloxypyridinium methylsulfate (2e) as an off-white solid (3.06 g, 93\%).

${ }^{1} \mathrm{H}$ NMR $\left(600 \mathrm{MHz},\left(\mathrm{CD}_{3}\right)_{2} \mathrm{SO}\right) \delta 9.27\left(\mathrm{~d}, \mathrm{~J}=7.2 \mathrm{~Hz}, 2 \mathrm{H}, \mathrm{H}_{1}\right), 7.76\left(\mathrm{~d}, \mathrm{~J}=7.2 \mathrm{~Hz}, 2 \mathrm{H}, \mathrm{H}_{2}\right), 7.50-7.49(\mathrm{~m}$, $\left.2 \mathrm{H}, \mathrm{H}_{5}\right), 7.43-7.36\left(\mathrm{~m}, 3 \mathrm{H}, 2 \times \mathrm{H}_{4}, 1 \times \mathrm{H}_{6}\right), 5.47\left(\mathrm{~s}, 2 \mathrm{H}, \mathrm{H}_{3}\right), 4.31\left(\mathrm{~s}, 3 \mathrm{H}, \mathrm{H}_{7}\right), 3.40\left(\mathrm{~s}, 3 \mathrm{H}, \mathrm{H}_{8}\right) .{ }^{13} \mathrm{C} \mathrm{NMR}$ $\left(150 \mathrm{MHz},\left(\mathrm{CD}_{3}\right)_{2} \mathrm{SO}\right) \delta 169.5(\mathrm{C}), 143.0(\mathrm{CH}), 134.7(\mathrm{C}), 129.3(\mathrm{CH}), 129.2(\mathrm{CH}), 128.9(\mathrm{CH}), 115.0$ $(\mathrm{CH}), 73.0\left(\mathrm{CH}_{2}\right), 69.8\left(\mathrm{CH}_{3}\right), 53.4\left(\mathrm{CH}_{3}\right)$. IR (ATR-FTIR), $\mathrm{cm}^{-1}$ : $3123(\mathrm{w}), 1626(\mathrm{~m}), 1507(\mathrm{~m}), 1213(\mathrm{~s})$, 989 (s), 735 (s), $553(\mathrm{~m})$. HRMS-ESI (m/z): [M $\left.-\mathrm{CH}_{3} \mathrm{OSO}_{3}^{-}\right]^{+}$calcd for $\mathrm{C}_{13} \mathrm{H}_{14} \mathrm{NO}_{2}, 216.1019$; found, 216.1029. 


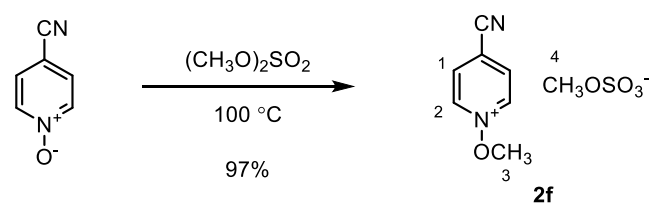

Preparation of $\mathrm{N}$-methoxy 4-cyanopyridinium methylsulfate (2f):

A $25-\mathrm{mL}$ round-bottomed flask fitted with a rubber septum was charged with 4-cyanopyridine $N$ oxide (1.20 g, $10.0 \mathrm{mmol}, 1$ equiv). The reaction vessel was evacuated and refilled using a balloon of argon. This process was repeated twice. The reaction vessel was then cooled to $0{ }^{\circ} \mathrm{C}$. Dimethylsulfate $(1.26 \mathrm{~mL}, 10.0 \mathrm{mmol}, 1.00$ equiv) was added to the reaction vessel dropwise via syringe over $5 \mathrm{~min}$. The reaction vessel was placed in an oil bath that had been preheated to $100{ }^{\circ} \mathrm{C}$. The reaction mixture was stirred and heated for $9 \mathrm{~h}$ at $100{ }^{\circ} \mathrm{C}$. The product mixture was concentrated in vacuo $(0.1$ Torr $)$ overnight to afford $N$-methoxy 4-cyanopyridinium methylsulfate (2f) as an off-white solid $(2.39 \mathrm{~g}, 97 \%)$. Further attempts to purify the product lead to decomposition.

${ }^{1} \mathrm{H}$ NMR $\left(500 \mathrm{MHz},\left(\mathrm{CD}_{3}\right)_{2} \mathrm{SO}\right) \delta 9.73\left(\mathrm{~d}, \mathrm{~J}=8.5 \mathrm{~Hz}, 2 \mathrm{H}, \mathrm{H}_{2}\right), 8.78\left(\mathrm{~d}, \mathrm{~J}=8.5 \mathrm{~Hz}, 2 \mathrm{H}, \mathrm{H}_{1}\right), 4.48\left(\mathrm{~s}, 3 \mathrm{H}, \mathrm{H}_{3}\right)$, $3.35\left(\mathrm{~s}, 3 \mathrm{H}, \mathrm{H}_{4}\right) .{ }^{13} \mathrm{C}$ NMR $\left(125 \mathrm{MHz},\left(\mathrm{CD}_{3}\right)_{2} \mathrm{SO}\right) \delta 142.5(\mathrm{CH}), 132.9(\mathrm{CH}), 126.3(\mathrm{C}), 114.9(\mathrm{C}), 70.0$ $\left(\mathrm{CH}_{3}\right), 53.4\left(\mathrm{CH}_{3}\right)$. IR (ATR-FTIR), $\mathrm{cm}^{-1}$ : 3105 (w), 1624 (w), 1217 (s), 1193 (s), 999 (s), 743 (s), 578 (s). HRMS-ESI (m/z): [M - $\left.\mathrm{CH}_{3} \mathrm{OSO}_{3}^{-}\right]^{+}$calcd for $\mathrm{C}_{7} \mathrm{H}_{7} \mathrm{~N}_{2} \mathrm{O}, 135.0553$; found, 135.0561 . 


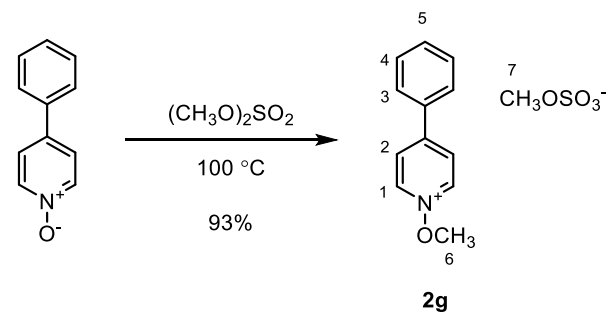

Preparation of $\mathrm{N}$-methoxy 4-phenylpyridinium methylsulfate (2g):

A $25-\mathrm{mL}$ round-bottomed flask fitted with a rubber septum was charged with 4-phenylpyridine $N$ oxide (1.71 g, $10.0 \mathrm{mmol}, 1$ equiv). The reaction vessel was evacuated and refilled using a balloon of argon. This process was repeated twice. The reaction vessel was then cooled to $0{ }^{\circ} \mathrm{C}$. Dimethylsulfate ( $1.26 \mathrm{~mL}, 10.0 \mathrm{mmol}, 1.00$ equiv) was added to the reaction vessel dropwise via syringe over $5 \mathrm{~min}$. The reaction vessel was placed in an oil bath that had been preheated to $100{ }^{\circ} \mathrm{C}$. The reaction mixture was stirred and heated for $3 \mathrm{~h}$ at $100{ }^{\circ} \mathrm{C}$. The product mixture was concentrated to dryness and the residue obtained was purified by recrystallization from anhydrous acetone under an atmosphere of argon to afford $N$-methoxy 4-phenylpyridinium methylsulfate $(\mathbf{2 g})$ as an off-white solid $(2.77 \mathrm{~g}, 93 \%)$.

${ }^{1} \mathrm{H}$ NMR $\left(500 \mathrm{MHz},\left(\mathrm{CD}_{3}\right)_{2} \mathrm{SO}\right) \delta 9.48\left(\mathrm{~d}, \mathrm{~J}=6.5 \mathrm{~Hz}, 2 \mathrm{H}, \mathrm{H}_{1}\right), 8.58\left(\mathrm{~d}, \mathrm{~J}=6.5 \mathrm{~Hz}, 2 \mathrm{H}, \mathrm{H}_{2}\right), 8.08-8.06(\mathrm{~m}$, $\left.2 \mathrm{H}, \mathrm{H}_{4}\right), 7.64-7.62\left(\mathrm{~m}, 3 \mathrm{H}, 2 \times \mathrm{H}_{3}, 1 \times \mathrm{H}_{5}\right), 4.44\left(\mathrm{~s}, 3 \mathrm{H}, \mathrm{H}_{6}\right), 3.37\left(\mathrm{~s}, 3 \mathrm{H}, \mathrm{H}_{7}\right) .{ }^{13} \mathrm{C} \mathrm{NMR}(150 \mathrm{MHz}$, $\left.\left(\mathrm{CD}_{3}\right)_{2} \mathrm{SO}\right) \delta 159.6(\mathrm{C}), 146.1(\mathrm{C}), 138.5(\mathrm{CH}), 137.4(\mathrm{CH}), 134.9(\mathrm{CH}), 133.5(\mathrm{CH}), 130.9(\mathrm{CH}), 74.7$ $\left(\mathrm{CH}_{3}\right), 58.1\left(\mathrm{CH}_{3}\right)$. IR 3057 (w), $1620(\mathrm{~m}), 1415(\mathrm{~s}), 1156(\mathrm{~s}), 1106(\mathrm{~s}), 735$ (s), $573(\mathrm{~s})$. HRMS-ESI (m/z): $\left[\mathrm{M}-\mathrm{CH}_{3} \mathrm{OSO}_{3}\right]^{+}$calcd for $\mathrm{C}_{12} \mathrm{H}_{12} \mathrm{NO}, 186.0913$; found, 186.0917 . 


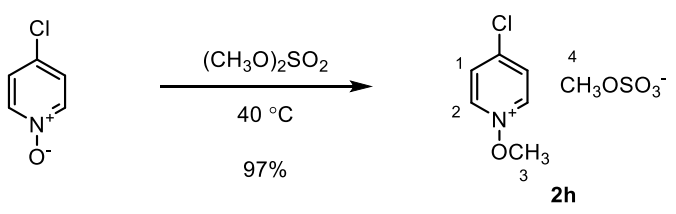

Preparation of N-methoxy 4-chloropyridinium methylsulfate $(\mathbf{2 h})$ :

A $10-\mathrm{mL}$ round-bottomed flask fitted with a rubber septum was charged with 4-chloropyridine $N$ oxide (389 mg, $3.00 \mathrm{mmol}, 1$ equiv). The reaction vessel was evacuated and refilled using a balloon of argon. This process was repeated twice. The reaction vessel was then cooled to $0{ }^{\circ} \mathrm{C}$. Dimethylsulfate ( $285 \mu \mathrm{L}, 3.00 \mathrm{mmol}, 1.00$ equiv) was added to the reaction vessel dropwise via syringe over $5 \mathrm{~min}$. The reaction vessel was placed in an oil bath that had been preheated to $40{ }^{\circ} \mathrm{C}$. The reaction mixture was stirred and heated for $2 \mathrm{~h}$ at $40{ }^{\circ} \mathrm{C}$. The product mixture was concentrated in vacuo ( 0.1 Torr) overnight to afford $\mathrm{N}$-methoxy 4-chloropyridinium methylsulfate (2h) as an off-white solid (744 $\mathrm{mg}, 97 \%)$. Further attempts to purify the product lead to decomposition.

${ }^{1} \mathrm{H}$ NMR $\left(400 \mathrm{MHz},\left(\mathrm{CD}_{3}\right)_{2} \mathrm{SO}\right) \delta 9.49\left(\mathrm{~d}, \mathrm{~J}=8.0 \mathrm{~Hz}, 2 \mathrm{H}, \mathrm{H}_{2}\right), 8.45\left(\mathrm{~d}, \mathrm{~J}=8.0 \mathrm{~Hz}, 2 \mathrm{H}, \mathrm{H}_{1}\right), 4.40\left(\mathrm{~s}, 3 \mathrm{H}, \mathrm{H}_{3}\right)$, $3.35\left(\mathrm{~s}, 3 \mathrm{H}, \mathrm{H}_{4}\right) .{ }^{13} \mathrm{C}$ NMR $\left(125 \mathrm{MHz},\left(\mathrm{CD}_{3}\right)_{2} \mathrm{SO}\right) \delta 151.7(\mathrm{C}), 142.7(\mathrm{CH}), 129.9(\mathrm{CH}), 70.2\left(\mathrm{CH}_{3}\right), 53.3$ $\left(\mathrm{CH}_{3}\right)$. IR (ATR-FTIR), $\mathrm{cm}^{-1}: 3000(\mathrm{w}), 1437$ (w), $1229(\mathrm{w}), 1023(\mathrm{~s}), 952(\mathrm{~m}), 821$ (s), 736 (s). HRMSESI (m/z): $\left[\mathrm{M}-\mathrm{CH}_{3} \mathrm{OSO}_{3}{ }^{-}\right]^{+}$calcd for $\mathrm{C}_{6} \mathrm{H}_{7}{ }^{35} \mathrm{ClNO}, 144.0211$; found, 144.0220 . 


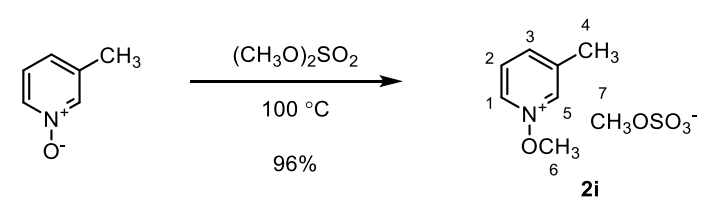

Preparation of N-methoxy 3-methylpyridinium methylsulfate (2i):

A $25-\mathrm{mL}$ round-bottomed flask fitted with a rubber septum was charged with 3-methylpyridine $\mathrm{N}$ oxide (581 mg, $5.32 \mathrm{mmol}, 1$ equiv). The reaction vessel was evacuated and refilled using a balloon of argon. This process was repeated twice. The reaction vessel was then cooled to $0{ }^{\circ} \mathrm{C}$. Dimethylsulfate (504 $\mu \mathrm{L}, 5.32 \mathrm{mmol}, 1.00$ equiv) was added to the reaction vessel dropwise via syringe over $5 \mathrm{~min}$. The reaction vessel was placed in an oil bath that had been preheated to $100{ }^{\circ} \mathrm{C}$. The reaction mixture was stirred and heated for $3 \mathrm{~h}$ at $100{ }^{\circ} \mathrm{C}$. The product mixture was concentrated in vacuo $(0.1$ Torr $)$ overnight to afford $N$-methoxy 3-methylpyridinium methylsulfate (2i) as a colorless gum (1.19 g, 96\%).

${ }^{1} \mathrm{H}$ NMR (400 MHz, $\left.\left(\mathrm{CD}_{3}\right)_{2} \mathrm{SO}\right) \delta 9.36\left(\mathrm{~s}, 1 \mathrm{H}, \mathrm{H}_{5}\right), 9.27$ (d, J = 7.6 Hz, 1H, H $), 8.45\left(\mathrm{~d}, \mathrm{~J}=8.0 \mathrm{~Hz}, 1 \mathrm{H}, \mathrm{H}_{3}\right)$, $8.12\left(\mathrm{t}, \mathrm{J}=7.8 \mathrm{~Hz}, 1 \mathrm{H}, \mathrm{H}_{2}\right), 4.40\left(\mathrm{~s}, 3 \mathrm{H}, \mathrm{H}_{6}\right), 3.36\left(\mathrm{~s}, 3 \mathrm{H}, \mathrm{H}_{7}\right), 2.51\left(\mathrm{~s}, 3 \mathrm{H}, \mathrm{H}_{4}\right) .{ }^{13} \mathrm{C} \mathrm{NMR}(100 \mathrm{MHz}$, $\left.\left(\mathrm{CD}_{3}\right)_{2} \mathrm{SO}\right) \delta 145.8(\mathrm{CH}), 141.1(\mathrm{C}), 140.7(\mathrm{CH}), 138.4(\mathrm{CH}), 128.8(\mathrm{CH}), 69.9\left(\mathrm{CH}_{3}\right), 53.3\left(\mathrm{CH}_{3}\right), 18.3$ $\left(\mathrm{CH}_{3}\right)$. IR (ATR-FTIR), $\mathrm{cm}^{-1}: 3045$ (w), 1461 (w), 1217 (s), 1003 (s), 726 (s). HRMS-ESI (m/z): [M $\left.\mathrm{CH}_{3} \mathrm{OSO}_{3}^{-}\right]^{+}$calcd for $\mathrm{C}_{7} \mathrm{H}_{10} \mathrm{NO}, 124.0757$; found, 124.0761 . 


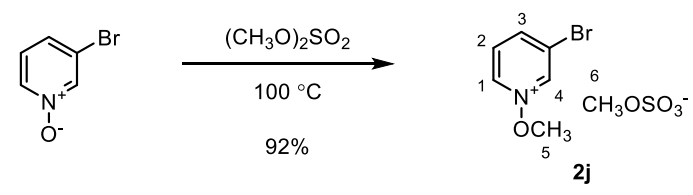

Preparation of $\mathrm{N}$-methoxy 3-methylpyridinium methylsulfate (2j):

A $25-\mathrm{mL}$ round-bottomed flask fitted with a rubber septum was charged with 3-methylpyridine $\mathrm{N}$ oxide (581 mg, $5.32 \mathrm{mmol}, 1$ equiv). The reaction vessel was evacuated and refilled using a balloon of argon. This process was repeated twice. The reaction vessel was then cooled to $0{ }^{\circ} \mathrm{C}$. Dimethylsulfate (504 $\mu \mathrm{L}, 5.32 \mathrm{mmol}, 1.00$ equiv) was added to the reaction vessel dropwise via syringe over $5 \mathrm{~min}$. The reaction vessel was placed in an oil bath that had been preheated to $100{ }^{\circ} \mathrm{C}$. The reaction mixture was stirred and heated for $3 \mathrm{~h}$ at $100{ }^{\circ} \mathrm{C}$. The product mixture was concentrated in vacuo $(0.1 \mathrm{Torr})$ overnight to afford $N$-methoxy 3-bromopyridinium methylsulfate (2j) as a colorless gum (1.10 g, 92\%).

${ }^{1} \mathrm{H} \mathrm{NMR}\left(400 \mathrm{MHz},\left(\mathrm{CD}_{3}\right)_{2} \mathrm{SO}\right) \delta 9.32\left(\mathrm{~s}, 1 \mathrm{H}, \mathrm{H}_{4}\right), 9.49\left(\mathrm{~d}, \mathrm{~J}=7.2 \mathrm{~Hz}, 1 \mathrm{H}, \mathrm{H}_{1}\right), 8.86\left(\mathrm{~d}, \mathrm{~J}=8.8 \mathrm{~Hz}, 1 \mathrm{H}, \mathrm{H}_{3}\right)$, $8.17\left(\mathrm{t}, \mathrm{J}=7.4 \mathrm{~Hz}, 1 \mathrm{H}, \mathrm{H}_{2}\right), 4.43\left(\mathrm{~s}, 3 \mathrm{H}, \mathrm{H}_{5}\right), 3.35\left(\mathrm{~s}, 3 \mathrm{H}, \mathrm{H}_{6}\right) .{ }^{13} \mathrm{C} \mathrm{NMR}\left(100 \mathrm{MHz},\left(\mathrm{CD}_{3}\right)_{2} \mathrm{SO}\right) \delta 147.8$ $(\mathrm{CH}), 142.9(\mathrm{CH}), 140.5(\mathrm{CH}), 130.0(\mathrm{CH}), 122.9(\mathrm{C}), 70.4\left(\mathrm{CH}_{3}\right), 53.3\left(\mathrm{CH}_{3}\right)$. IR (ATR-FTIR), $\mathrm{cm}^{-1}: 3033$ $(\mathrm{w}), 1477(\mathrm{~m}), 1216(\mathrm{~s}), 1000(\mathrm{~s}), 732(\mathrm{~s}), 576(\mathrm{~s})$. HRMS-ESI $(\mathrm{m} / \mathrm{z}):\left[\mathrm{M}-\mathrm{CH}_{3} \mathrm{OSO}_{3}\right]^{+}$calcd for $\mathrm{C}_{6} \mathrm{H}_{9}{ }^{79 / 81} \mathrm{BrNO}, 187.9706 / 189.9685$; found, $187.9706 / 189.9690$. 


\section{Optimization of the Hydropyridylation (Table 1, Entry 1).}

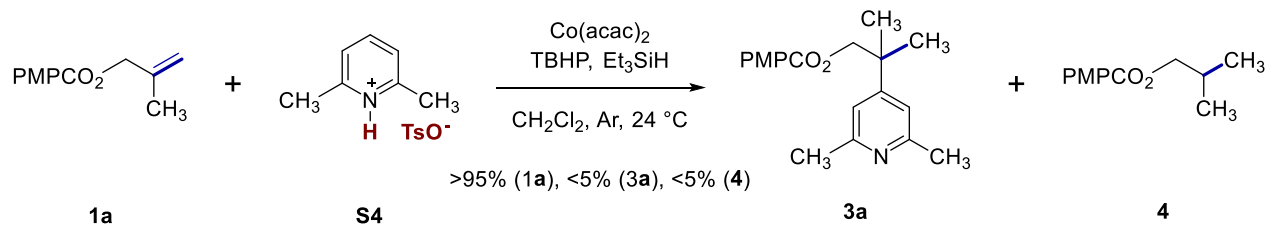

A 10-mL round-bottomed flask fitted with a rubber septum was charged sequentially with 2,6lutidine (53.5 mg, $500 \mu \mathrm{mol}, 5.00$ equiv) and $p$-toluenesulfonic acid monohydrate $(96.1 \mathrm{mg}, 505 \mu \mathrm{mol}, 5.05$ equiv). The reaction vessel was evacuated and refilled using a balloon of argon. This process was repeated twice. Dichloromethane $(5.0 \mathrm{~mL})$ was added to the reaction vessel via syringe and the reaction mixture was stirred for $12 \mathrm{~h}$ at $24{ }^{\circ} \mathrm{C}$. The solvent was removed in vacuo and the residue obtained was dried by azeotropic distillation with benzene $(5.0 \mathrm{~mL})$. This process was repeated twice. 2-Methylallyl 4methoxybenzoate (1a, $20.6 \mathrm{mg}, 100 \mu \mathrm{mol}, 1$ equiv) and cobalt bis(acetylacetonate) $(25.7 \mathrm{mg}, 100 \mu \mathrm{mol}$, 1.00 equiv) were then added in sequence. The reaction vessel was evacuated and refilled using a balloon of argon. This process was repeated twice. Dichloromethane $(500 \mu \mathrm{L})$, triethylsilane $(80.0 \mu \mathrm{L}, 500 \mu \mathrm{mol}$, 5.00 equiv), and a solution of tert-butyl hydroperoxide in nonane $(\sim 5.5 \mathrm{M}, 18.2 \mu \mathrm{L}, 100 \mu \mathrm{mol}, 1.00$ equiv) were then added in sequence via syringe. The reaction mixture was stirred for $16 \mathrm{~h}$ at $24{ }^{\circ} \mathrm{C}$. The product mixture was transferred to a separatory funnel that had been charged with ethyl acetate $(50 \mathrm{~mL})$. The diluted product mixture was washed with $3 \mathrm{M}$ aqueous ammonium hydroxide solution $(3 \times 10 \mathrm{~mL})$. The organic layer was isolated and the isolated organic layer was dried over sodium sulfate. The dried solution was filtered and the filtrate was concentrated. ${ }^{1} \mathrm{H}$ NMR analysis of the unpurified mixture using mesitylene as an internal standard indicated $>95 \%$ yield of $\mathbf{1 a},<5 \%$ yield of $\mathbf{3 a}$, and $<5 \%$ yield of $\mathbf{4}$. 


\section{Optimization of the Hydropyridylation (Table 1, Entry 2).}

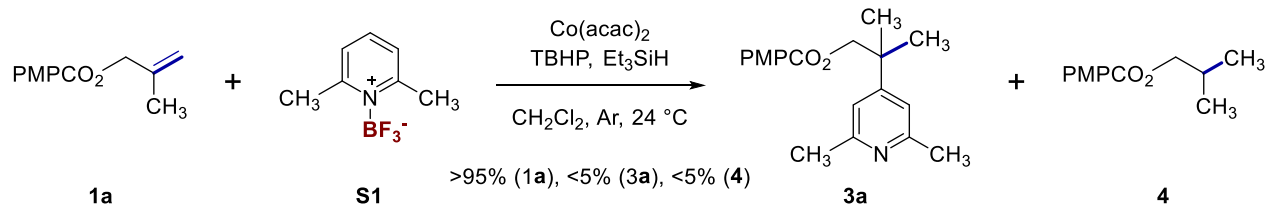

A $10-\mathrm{mL}$ round-bottomed flask fitted with a rubber septum was charged sequentially with 2,6lutidine $(53.5 \mathrm{mg}, 500 \mu \mathrm{mol}, 5.00$ equiv) and boron trifluoride diethyl etherate complex $(61.7 \mu \mathrm{L}, 500 \mu \mathrm{mol}$, 5.00 equiv). The reaction vessel was evacuated and refilled using a balloon of argon. This process was repeated twice. Dichloromethane $(5.0 \mathrm{~mL})$ was added to the reaction vessel via syringe and the reaction mixture was stirred for $12 \mathrm{~h}$ at $24{ }^{\circ} \mathrm{C}$. The solvent was removed in vacuo and the residue obtained was dried by azeotropic distillation with benzene $(5.0 \mathrm{~mL})$. This process was repeated twice. 2-Methylallyl 4methoxybenzoate (1a, $20.6 \mathrm{mg}, 100 \mu \mathrm{mol}, 1$ equiv) and cobalt bis(acetylacetonate) $(25.7 \mathrm{mg}, 100 \mu \mathrm{mol}$, 1.00 equiv) were then added in sequence. The reaction vessel was evacuated and refilled using a balloon of argon. This process was repeated twice. Dichloromethane $(500 \mu \mathrm{L})$, triethylsilane $(80.0 \mu \mathrm{L}, 500 \mu \mathrm{mol}$, 5.00 equiv), and a solution of tert-butyl hydroperoxide in nonane $(\sim 5.5 \mathrm{M}, 18.2 \mu \mathrm{L}, 100 \mu \mathrm{mol}, 1.00$ equiv) were then added in sequence via syringe. The reaction mixture was stirred for $16 \mathrm{~h}$ at $24{ }^{\circ} \mathrm{C}$. The product mixture was transferred to a separatory funnel that had been charged with ethyl acetate $(50 \mathrm{~mL})$. The diluted product mixture was washed with $3 \mathrm{M}$ aqueous ammonium hydroxide solution $(3 \times 10 \mathrm{~mL})$. The organic layer was isolated and the isolated organic layer was dried over sodium sulfate. The dried solution was filtered and the filtrate was concentrated. ${ }^{1} \mathrm{H}$ NMR analysis of the unpurified mixture using mesitylene as an internal standard indicated $>95 \%$ yield of $\mathbf{1 a},<5 \%$ yield of $\mathbf{3 a}$, and $<5 \%$ yield of $\mathbf{4}$. 


\section{Optimization of the Hydropyridylation (Table 1, Entry 3).}

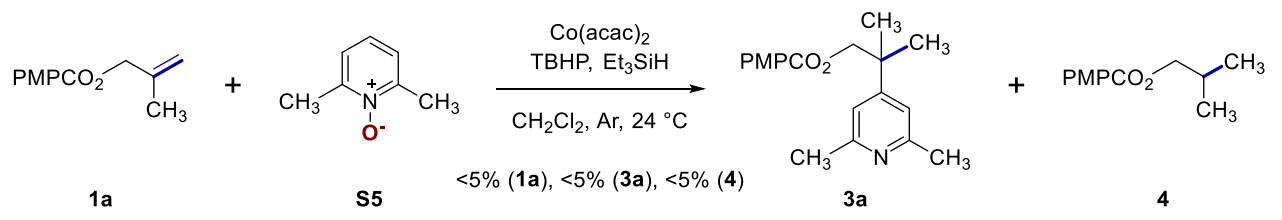

A 10-mL round-bottomed flask fitted with a rubber septum was charged sequentially with 2methylallyl 4-methoxybenzoate (1a, $20.6 \mathrm{mg}, 100 \mu \mathrm{mol}, 1$ equiv), 2,6-lutidine $N$-oxide ( $61.6 \mathrm{mg}, 500 \mu \mathrm{mol}$, 5.00 equiv), and cobalt bis(acetylacetonate) $(25.7 \mathrm{mg}, 100 \mu \mathrm{mol}, 1.00$ equiv). The reaction vessel was evacuated and refilled using a balloon of argon. This process was repeated twice. Dichloromethane (500 $\mu \mathrm{L})$, triethylsilane $(80.0 \mu \mathrm{L}, 500 \mu \mathrm{mol}, 5.00$ equiv), and a solution of tert-butyl hydroperoxide in nonane $(\sim 5.5 \mathrm{M}, 18.2 \mu \mathrm{L}, 100 \mu \mathrm{mol}, 1.00$ equiv) were then added in sequence via syringe. The reaction mixture was stirred for $16 \mathrm{~h}$ at $24{ }^{\circ} \mathrm{C}$. The product mixture was transferred to a separatory funnel that had been charged with ethyl acetate $(50 \mathrm{~mL})$. The diluted product mixture was washed with $3 \mathrm{M}$ aqueous ammonium hydroxide solution $(3 \times 10 \mathrm{~mL})$. The organic layer was isolated and the isolated organic layer was dried over sodium sulfate. The dried solution was filtered and the filtrate was concentrated. ${ }^{1} \mathrm{H}$ NMR analysis of the unpurified mixture using mesitylene as an internal standard indicated $<5 \%$ yield of $\mathbf{1 a},<5 \%$ yield of $\mathbf{3 a}$, and $<5 \%$ yield of $\mathbf{4}$. 


\section{Optimization of the Hydropyridylation (Table 1, Entry 4).}

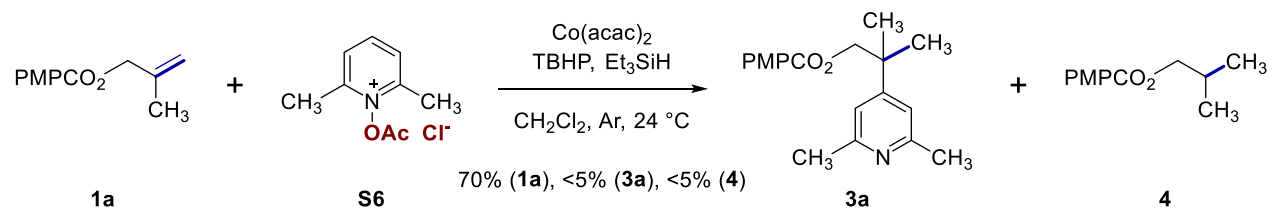

A $10-\mathrm{mL}$ round-bottomed flask fitted with a rubber septum was charged sequentially with 2,6lutidine $N$-oxide $(61.6 \mathrm{mg}, 500 \mu \mathrm{mol}, 5.00$ equiv) and acetyl chloride $(35.5 \mu \mathrm{L}, 500 \mu \mathrm{mol}, 5.00$ equiv). The reaction vessel was evacuated and refilled using a balloon of argon. This process was repeated twice. Dichloromethane $(5.0 \mathrm{~mL})$ was added to the reaction vessel via syringe and the reaction mixture was stirred for $12 \mathrm{~h}$ at $24{ }^{\circ} \mathrm{C}$. The solvent was removed in vacuo and the residue obtained was dried by azeotropic distillation with benzene $(5.0 \mathrm{~mL})$. This process was repeated twice. 2-Methylallyl 4-methoxybenzoate (1a, $20.6 \mathrm{mg}, 100 \mu \mathrm{mol}, 1$ equiv) and cobalt bis(acetylacetonate) $(25.7 \mathrm{mg}, 100 \mu \mathrm{mol}, 1.00$ equiv) were then added in sequence. The reaction vessel was evacuated and refilled using a balloon of argon. This process was repeated twice. Dichloromethane $(500 \mu \mathrm{L})$, triethylsilane $(80.0 \mu \mathrm{L}, 500 \mu \mathrm{mol}, 5.00$ equiv), and a solution of tert-butyl hydroperoxide in nonane $(\sim 5.5 \mathrm{M}, 18.2 \mu \mathrm{L}, 100 \mu \mathrm{mol}, 1.00$ equiv) were then added in sequence via syringe. The reaction mixture was stirred for $16 \mathrm{~h}$ at $24{ }^{\circ} \mathrm{C}$. The product mixture was transferred to a separatory funnel that had been charged with ethyl acetate $(50 \mathrm{~mL})$. The diluted product mixture was washed with $3 \mathrm{M}$ aqueous ammonium hydroxide solution $(3 \times 10 \mathrm{~mL})$. The organic layer was isolated and the isolated organic layer was dried over sodium sulfate. The dried solution was filtered and the filtrate was concentrated. ${ }^{1} \mathrm{H}$ NMR analysis of the unpurified mixture using mesitylene as an internal standard indicated $70 \%$ yield of $\mathbf{1 a},<5 \%$ yield of $\mathbf{3 a}$, and $<5 \%$ yield of $\mathbf{4}$. 


\section{Optimization of the Hydropyridylation (Table 1, Entry 5).}

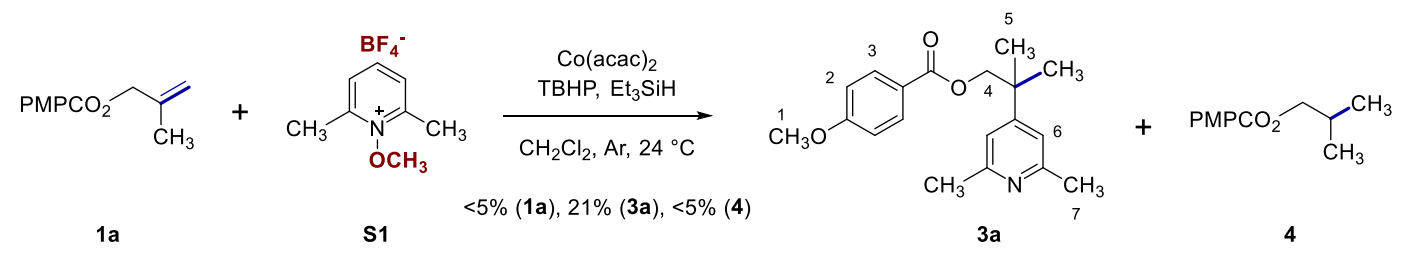

A 10-mL round-bottomed flask fitted with a rubber septum was charged sequentially with 2methylallyl 4-methoxybenzoate (1a, $20.6 \mathrm{mg}, 100 \mu \mathrm{mol}, 1$ equiv), $N$-methoxy 2,6-lutidinium tetrafluoroborate (S1, $113 \mathrm{mg}, 500 \mu \mathrm{mol}, 5.00$ equiv), and cobalt bis(acetylacetonate) $(25.7 \mathrm{mg}, 100 \mu \mathrm{mol}$, 1.00 equiv). The reaction vessel was evacuated and refilled using a balloon of argon. This process was repeated twice. Dichloromethane $(500 \mu \mathrm{L})$, triethylsilane $(80.0 \mu \mathrm{L}, 500 \mu \mathrm{mol}, 5.00$ equiv), and a solution of tert-butyl hydroperoxide in nonane $(\sim 5.5 \mathrm{M}, 18.2 \mu \mathrm{L}, 100 \mu \mathrm{mol}, 1.00$ equiv) were then added in sequence via syringe. The reaction vessel was protected from light with aluminum foil. The reaction mixture was stirred for $16 \mathrm{~h}$ at $24^{\circ} \mathrm{C}$. The product mixture was transferred to a separatory funnel that had been charged with ethyl acetate $(50 \mathrm{~mL})$. The diluted product mixture was washed with $3 \mathrm{M}$ aqueous ammonium hydroxide solution $(3 \times 10 \mathrm{~mL})$. The organic layer was isolated and the isolated organic layer was dried over sodium sulfate. The dried solution was filtered and the filtrate was concentrated. ${ }^{1} \mathrm{H}$ NMR analysis of the unpurified mixture using mesityelen as an internal standard indicated $<5 \%$ yield of 1a, $23 \%$ yield of 3a, and $<5 \%$ yield of $\mathbf{4}$. The NMR sample was concentrated to dryness and the residue obtained was purified by flash-column chromatography (eluting with $15 \%$ acetone- $10 \%$ dichloromethane- $0.5 \%$ triethylamine-hexanes). The mixture obtained was further purified by flash-column chromatography (eluting with $7.5 \%$ ether-10\% dichloromethane-5\% triethylamine-hexanes) to afford 2-(2,6dimethylpyridin-4-yl)-2-methylpropyl 4-methoxybenzoate (3a) as a colorless oil (3.9 $\mathrm{mg}, 21 \%)$.

2-(2,6-Dimethylpyridin-4-yl)-2-methylpropyl 4-methoxybenzoate (3a): $\mathrm{R}_{f}=0.34$ (15\% acetone-10\% dichloromethane- $0.5 \%$ triethylamine-hexanes; UV) ${ }^{1} \mathrm{H}$ NMR $\left(500 \mathrm{MHz}, \mathrm{CDCl}_{3}\right) \delta 7.88(\mathrm{~d}, \mathrm{~J}=9.0 \mathrm{~Hz}, 2 \mathrm{H}$, $\left.\mathrm{H}_{2}\right), 6.99$ (s, 2H, $\left.\mathrm{H}_{6}\right), 6.88\left(\mathrm{~d}, \mathrm{~J}=8.5 \mathrm{~Hz}, 2 \mathrm{H}, \mathrm{H}_{3}\right), 4.31\left(\mathrm{~s}, 2 \mathrm{H}, \mathrm{H}_{4}\right), 3.84\left(\mathrm{~s}, 3 \mathrm{H}, \mathrm{H}_{1}\right), 2.51\left(\mathrm{~s}, 6 \mathrm{H}, \mathrm{H}_{7}\right), 1.39$ $\left(\mathrm{s}, 6 \mathrm{H}, \mathrm{H}_{5}\right) .{ }^{13} \mathrm{C}$ NMR $\left(125 \mathrm{MHz}, \mathrm{CDCl}_{3}\right) \delta 166.0(\mathrm{C}), 136.4(\mathrm{C}), 157.6(\mathrm{C}), 156.0(\mathrm{C}), 131.5(\mathrm{CH}), 122.4$ (C), $117.8(\mathrm{CH}), 113.6(\mathrm{CH}), 72.2\left(\mathrm{CH}_{2}\right), 55.4\left(\mathrm{CH}_{3}\right), 38.3(\mathrm{C}), 25.4\left(\mathrm{CH}_{3}\right), 24.5\left(\mathrm{CH}_{3}\right)$. IR (ATR-FTIR), $\mathrm{cm}^{-1}: 2867(\mathrm{w}), 1712(\mathrm{~m}), 1606(\mathrm{~m}), 1256(\mathrm{~s}), 1167(\mathrm{~m}), 1102(\mathrm{~m})$. HRMS-ESI (m/z): $[\mathrm{M}+\mathrm{H}]^{+}$calcd for $\mathrm{C}_{19} \mathrm{H}_{24} \mathrm{NO}_{3}, 314.1751$; found, 314.1771 . 


\section{Optimization of the Hydropyridylation (Table 1, Entry 6).}

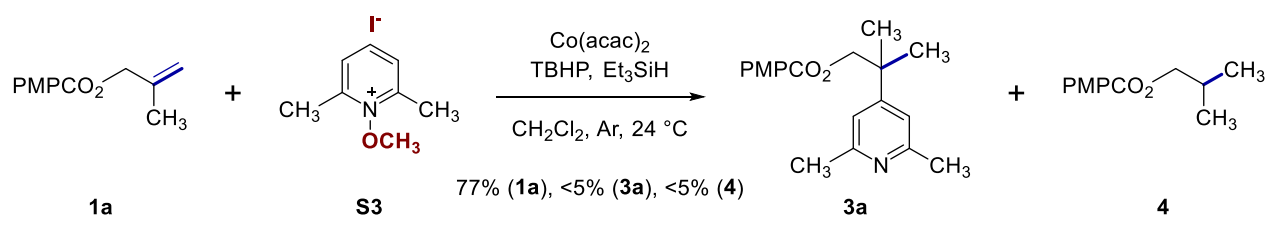

A 10-mL round-bottomed flask fitted with a rubber septum was charged sequentially with 2methylallyl 4-methoxybenzoate (1a, $20.6 \mathrm{mg}, 100 \mu \mathrm{mol}, 1$ equiv), $N$-methoxy 2,6-lutidinium iodide (S3, $132 \mathrm{mg}, 500 \mu \mathrm{mol}, 5.00$ equiv), and cobalt bis(acetylacetonate) $(25.7 \mathrm{mg}, 100 \mu \mathrm{mol}, 1.00 \mathrm{equiv})$. The reaction vessel was evacuated and refilled using a balloon of argon. This process was repeated twice. Dichloromethane $(500 \mu \mathrm{L})$, triethylsilane $(80.0 \mu \mathrm{L}, 500 \mu \mathrm{mol}, 5.00$ equiv), and a solution of tert-butyl hydroperoxide in nonane $(\sim 5.5 \mathrm{M}, 18.2 \mu \mathrm{L}, 100 \mu \mathrm{mol}, 1.00$ equiv) were then added in sequence via syringe. The reaction vessel was protected from light with aluminum foil. The reaction mixture was stirred for $16 \mathrm{~h}$ at $24{ }^{\circ} \mathrm{C}$. The product mixture was transferred to a separatory funnel that had been charged with ethyl acetate $(50 \mathrm{~mL})$. The diluted product mixture was washed with $3 \mathrm{M}$ aqueous ammonium hydroxide solution $(3 \times 10 \mathrm{~mL})$. The organic layer was isolated and the isolated organic layer was dried over sodium sulfate. The dried solution was filtered and the filtrate was concentrated. ${ }^{1} \mathrm{H}$ NMR analysis of the unpurified mixture using mesitylene as an internal standard indicated $77 \%$ yield of 1a, $<5 \%$ yield of 3a, and $<5 \%$ yield of 4 . 


\section{Optimization of the Hydropyridylation (Table 1, Entry 7).}

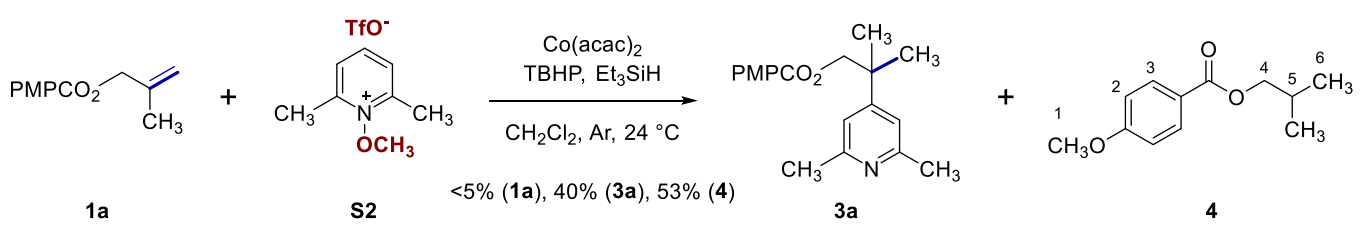

A $10-\mathrm{mL}$ round-bottomed flask fitted with a rubber septum was charged sequentially with 2methylallyl 4-methoxybenzoate (1a, $20.6 \mathrm{mg}, 100 \mu \mathrm{mol}, 1$ equiv), $N$-methoxy 2,6-lutidinium triflate (S2, $144 \mathrm{mg}, 500 \mu \mathrm{mol}, 5.00$ equiv), and cobalt bis(acetylacetonate) $(25.7 \mathrm{mg}, 100 \mu \mathrm{mol}, 1.00$ equiv). The reaction vessel was evacuated and refilled using a balloon of argon. This process was repeated twice. Dichloromethane $(500 \mu \mathrm{L})$, triethylsilane $(80.0 \mu \mathrm{L}, 500 \mu \mathrm{mol}, 5.00$ equiv), and a solution of tert-butyl hydroperoxide in nonane $(\sim 5.5 \mathrm{M}, 18.2 \mu \mathrm{L}, 100 \mu \mathrm{mol}, 1.00$ equiv) were then added in sequence via syringe. The reaction vessel was protected from light with aluminum foil. The reaction mixture was stirred for $16 \mathrm{~h}$ at $24{ }^{\circ} \mathrm{C}$. The product mixture was transferred to a separatory funnel that had been charged with ethyl acetate $(50 \mathrm{~mL})$. The diluted product mixture was washed with $3 \mathrm{M}$ aqueous ammonium hydroxide solution $(3 \times 10 \mathrm{~mL})$. The organic layer was isolated and the isolated organic layer was dried over sodium sulfate. The dried solution was filtered and the filtrate was concentrated. ${ }^{1} \mathrm{H}$ NMR analysis of the unpurified mixture using mesitylene as an internal standard indicated $<5 \%$ yield of 1a, $40 \%$ yield of 3a, and $53 \%$ yield of $\mathbf{4}$. The NMR sample was concentrated to dryness. The residue obtained was purified by preparative thin-layer chromatography (eluting with $15 \%$ ether-hexanes) to afford an analytically pure sample of 4 (colorless oil, $10.2 \mathrm{mg}, 49 \%$ ).

Isobutyl 4-methoxybenzoate (4): ${ }^{1} \mathrm{H}$ NMR (400 MHz, $\left.\mathrm{CDCl}_{3}\right) \delta 8.01\left(\mathrm{~d}, 2 \mathrm{H}, \mathrm{J}=8.8 \mathrm{~Hz}, \mathrm{H}_{3}\right), 6.92(\mathrm{~d}, 2 \mathrm{H}, \mathrm{J}$ $\left.=8.8 \mathrm{~Hz}, \mathrm{H}_{2}\right), 4.07\left(\mathrm{~d}, \mathrm{~J}=6.8 \mathrm{~Hz}, 2 \mathrm{H}, \mathrm{H}_{4}\right), 3.86\left(\mathrm{~s} 3 \mathrm{H}, \mathrm{H}_{1}\right), 2.12-2.02\left(\mathrm{~m}, 1 \mathrm{H}, \mathrm{H}_{5}\right), 1.02(\mathrm{~d}, \mathrm{~J}=6.8 \mathrm{~Hz}, 6 \mathrm{H}$, $\left.\mathrm{H}_{6}\right) .{ }^{13} \mathrm{C} \mathrm{NMR}\left(100 \mathrm{MHz}, \mathrm{CDCl}_{3}\right) \delta 166.4(\mathrm{C}), 163.2(\mathrm{C}), 131.5(\mathrm{CH}), 123.0(\mathrm{C}), 113.5(\mathrm{CH}), 70.7\left(\mathrm{CH}_{2}\right)$, $55.4\left(\mathrm{CH}_{3}\right), 27.9(\mathrm{CH}), 19.2\left(\mathrm{CH}_{3}\right)$.

${ }^{1} \mathrm{H}$ and ${ }^{13} \mathrm{C}$ NMR data for isobutyl 4-methoxybenzoate (4) prepared in this way were in agreement with those previously described. ${ }^{15}$ 


\section{Optimization of the Hydropyridylation (Table 1, Entry 8; Table 2, entry 4).}

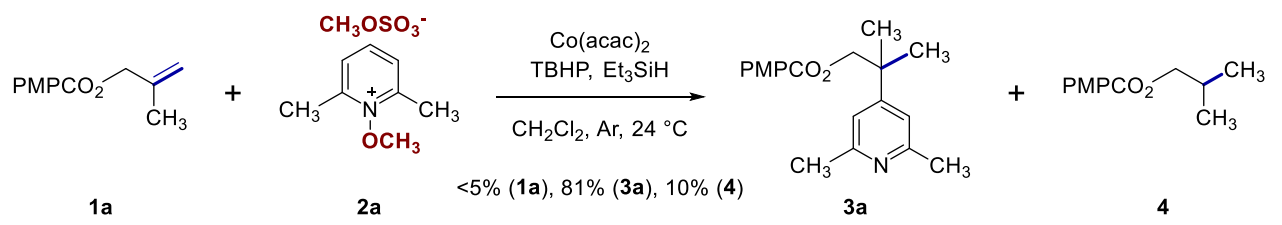

A $10-\mathrm{mL}$ round-bottomed flask fitted with a rubber septum was charged sequentially with 2methylallyl 4-methoxybenzoate (1a, $51.6 \mathrm{mg}, 250 \mu \mathrm{mol}, 1$ equiv), $N$-methoxy 2,6-lutidinium methylsulfate (2a, $312 \mathrm{mg}, 1.25 \mathrm{mmol}, 5.00$ equiv), and cobalt bis(acetylacetonate) (64.3 $\mathrm{mg}, 250 \mu \mathrm{mol}, 1.00$ equiv). The reaction vessel was evacuated and refilled using a balloon of argon. This process was repeated twice. Dichloromethane $(1.25 \mathrm{~mL})$, triethylsilane $(200 \mu \mathrm{L}, 1.25 \mathrm{mmol}, 5.00$ equiv), and a solution of tert-butyl hydroperoxide in nonane $(\sim 5.5 \mathrm{M}, 45.5 \mu \mathrm{L}, 250 \mu \mathrm{mol}, 1.00$ equiv) were then added in sequence via syringe. The reaction vessel was protected from light with aluminum foil. The reaction mixture was stirred for $16 \mathrm{~h}$ at $24{ }^{\circ} \mathrm{C}$. The product mixture was transferred to a separatory funnel that had been charged with ethyl acetate $(100 \mathrm{~mL})$. The diluted product mixture was washed with $3 \mathrm{M}$ aqueous ammonium hydroxide solution $(3 \times 25 \mathrm{~mL})$. The organic layer was isolated and the isolated organic layer was dried over sodium sulfate. The dried solution was filtered and the filtrate was concentrated. ${ }^{1} \mathrm{H}$ NMR analysis of the unpurified mixture using mesitylene as an internal standard indicated $<5 \%$ yield of 1a, $83 \%$ yield of 3a, and $10 \%$ yield of 4 . The NMR sample was concentrated to dryness and the residue obtained was purified by flash-column chromatography (eluting with $15 \%$ acetone- $10 \%$ dichloromethane- $0.5 \%$ triethylaminehexanes). The mixture obtained was further purified by flash-column chromatography (eluting with $7.5 \%$ ether-10\% dichloromethane-5\% triethylamine-hexanes) to afford 2-(2,6-dimethylpyridin-4-yl)-2methylpropyl 4-methoxybenzoate (3a) as a colorless oil $(63.2 \mathrm{mg}, 81 \%)$. 


\section{2-(2,6-Dimethylpyridin-4-yl)propyl 4-methoxybenzoate (3b; Table 2, entry 1)}

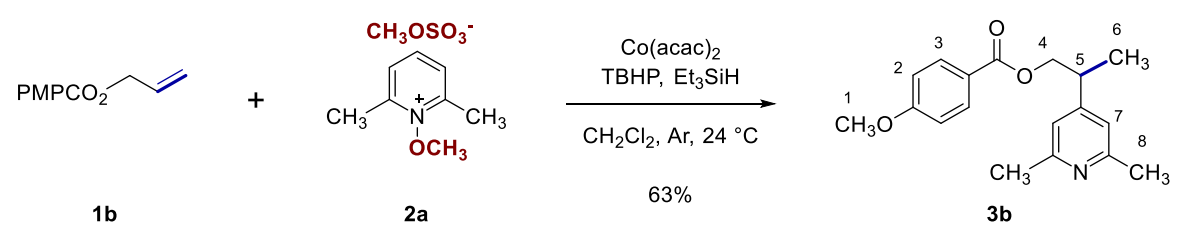

A $10-\mathrm{mL}$ round-bottomed flask fitted with a rubber septum was charged sequentially with allyl 4methoxybenzoate (1b, $48.1 \mathrm{mg}, 250 \mu \mathrm{mol}, 1$ equiv), $N$-methoxy 2,6-lutidinium methylsulfate (2a, $312 \mathrm{mg}$, $1.25 \mathrm{mmol}, 5.00$ equiv), and cobalt bis(acetylacetonate) $(64.3 \mathrm{mg}, 250 \mu \mathrm{mol}, 1.00$ equiv). The reaction vessel was evacuated and refilled using a balloon of argon. This process was repeated twice. Dichloromethane $(1.25 \mathrm{~mL})$, triethylsilane $(200 \mu \mathrm{L}, 1.25 \mathrm{mmol}, 5.00$ equiv), and a solution of tert-butyl hydroperoxide in nonane $(\sim 5.5 \mathrm{M}, 45.5 \mu \mathrm{L}, 250 \mu \mathrm{mol}, 1.00$ equiv) were then added in sequence via syringe. The reaction vessel was protected from light with aluminum foil. The reaction mixture was stirred for $16 \mathrm{~h}$ at $24{ }^{\circ} \mathrm{C}$. The product mixture was transferred to a separatory funnel that had been charged with ethyl acetate $(100 \mathrm{~mL})$. The diluted product mixture was washed with $3 \mathrm{M}$ aqueous ammonium hydroxide solution $(3 \times 25 \mathrm{~mL})$. The organic layer was isolated and the isolated organic layer was dried over sodium sulfate. The dried solution was filtered and the filtrate was concentrated. The residue obtained was purified by flash-column chromatography (eluting with $15 \%$ acetone-10\% dichloromethane- $0.5 \%$ triethylamine-hexanes). The mixture obtained was further purified by flash-column chromatography (eluting with $7.5 \%$ ether-10\% dichloromethane-5\% triethylamine-hexanes) to afford 2-(2,6dimethylpyridin-4-yl)propyl 4-methoxybenzoate (3b) as a colorless oil (47.3 mg, 63\%).

2-(2,6-Dimethylpyridin-4-yl)propyl 4-methoxybenzoate $\quad(\mathbf{3 b}): \mathrm{R}_{f}=0.31 \quad(15 \%$ acetone-10\% dichloromethane- $0.5 \%$ triethylamine-hexanes; UV). ${ }^{1} \mathrm{H} \mathrm{NMR}\left(400 \mathrm{MHz}, \mathrm{CDCl}_{3}\right) \delta 7.89(\mathrm{~d}, \mathrm{~J}=8.8 \mathrm{~Hz}, 2 \mathrm{H}$, $\left.\mathrm{H}_{2}\right), 6.88-6.86\left(\mathrm{~m}, 4 \mathrm{H}, 2 \times \mathrm{H}_{7}, 2 \times \mathrm{H}_{3}\right), 4.34\left(\mathrm{~d}, \mathrm{~J}=7.2 \mathrm{~Hz}, 2 \mathrm{H}, \mathrm{H}_{4}\right), 3.82\left(\mathrm{~s}, 3 \mathrm{H}, \mathrm{H}_{1}\right), 3.14-3.09(\mathrm{~m}, 1 \mathrm{H}$, $\left.\mathrm{H}_{5}\right), 2.49\left(\mathrm{~s}, 6 \mathrm{H}, \mathrm{H}_{8}\right), 1.33\left(\mathrm{~d}, \mathrm{~J}=6.8 \mathrm{~Hz}, 3 \mathrm{H}, \mathrm{H}_{6}\right) .{ }^{13} \mathrm{C} \mathrm{NMR}\left(100 \mathrm{MHz}, \mathrm{CDCl}_{3}\right) \delta 166.0(\mathrm{C}), 163.4(\mathrm{C})$, $157.8(\mathrm{C}), 152.7(\mathrm{C}), 131.5(\mathrm{CH}), 122.4(\mathrm{C}), 119.3(\mathrm{CH}), 113.6(\mathrm{CH}), 68.5\left(\mathrm{CH}_{2}\right), 55.4\left(\mathrm{CH}_{3}\right), 38.5(\mathrm{CH})$, $24.4\left(\mathrm{CH}_{3}\right), 17.4\left(\mathrm{CH}_{3}\right)$. IR (ATR-FTIR), $\mathrm{cm}^{-1}: 2868(\mathrm{w}), 1709(\mathrm{~m}), 1604(\mathrm{~m}), 1251(\mathrm{~s}), 1165$ (s), $1099(\mathrm{~s})$, $1026(\mathrm{~m}), 769(\mathrm{~m})$. HRMS-ESI (m/z): $[\mathrm{M}+\mathrm{H}]^{+}$calcd for $\mathrm{C}_{18} \mathrm{H}_{22} \mathrm{NO}_{3}, 300.1600$; found, 300.1600. 


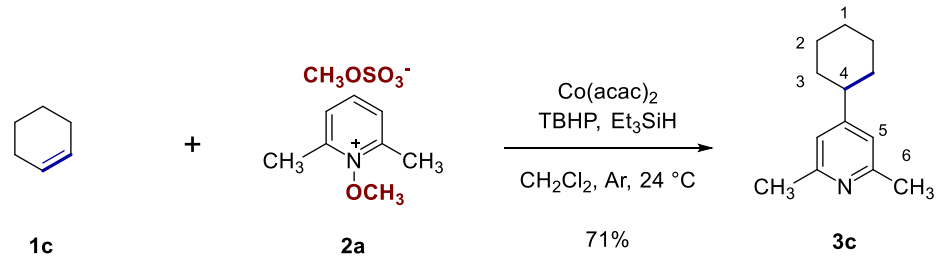

A $10-\mathrm{mL}$ round-bottomed flask fitted with a rubber septum was charged sequentially with $\mathrm{N}$ methoxy 2,6-lutidinium methylsulfate (2a, $312 \mathrm{mg}, 1.25 \mathrm{mmol}, 5.00$ equiv) and cobalt bis(acetylacetonate) (64.3 mg, $250 \mu \mathrm{mol}, 1.00$ equiv). The reaction vessel was evacuated and refilled using a balloon of argon. This process was repeated twice. Dichloromethane $(1.25 \mathrm{~mL})$, cyclohexene $(1 \mathrm{c}, 25.3 \mu \mathrm{L}, 250 \mu \mathrm{mol}, 1$ equiv), triethylsilane ( $200 \mu \mathrm{L}, 1.25 \mathrm{mmol}, 5.00$ equiv), and a solution of tert-butyl hydroperoxide in nonane $(\sim 5.5 \mathrm{M}, 45.5 \mu \mathrm{L}, 250 \mu \mathrm{mol}, 1.00$ equiv) were then added in sequence via syringe. The reaction vessel was protected from light with aluminum foil. The reaction mixture was stirred for $16 \mathrm{~h}$ at $24{ }^{\circ} \mathrm{C}$. The product mixture was transferred to a separatory funnel that had been charged with ethyl acetate $(100 \mathrm{~mL})$. The diluted product mixture was washed with $3 \mathrm{M}$ aqueous ammonium hydroxide solution $(3 \times 25 \mathrm{~mL})$. The organic layer was isolated and the isolated organic layer was dried over sodium sulfate. The dried solution was filtered and the filtrate was concentrated. The residue obtained was purified by flash-column chromatography (eluting with 5\% triethylamine-hexanes). The mixture obtained was further purified by automated flash-column chromatography (eluting with dichloromethane initially, grading to $10 \%$ methanol-dichloromethane, linear gradient) to afford 4-cyclohexyl-2,6-dimethylpyridine (3c) as a colorless oil (33.7 mg, 71\%).

4-Cyclohexyl-2,6-dimethylpyridine (3c): $\mathrm{R}_{f}=0.26$ (5\% triethylamine-hexanes; UV, CAM). ${ }^{1} \mathrm{H}$ NMR (400 $\left.\mathrm{MHz}, \mathrm{CDCl}_{3}\right) \delta 6.78\left(\mathrm{~s}, 2 \mathrm{H}, \mathrm{H}_{5}\right), 2.47\left(\mathrm{~s}, 6 \mathrm{H}, \mathrm{H}_{6}\right), 2.39$ (br s, 1H, $\left.\mathrm{H}_{4}\right), 1.83-1.81\left(\mathrm{~m}, 4 \mathrm{H}, 2 \times \mathrm{H}_{2}, 2 \times \mathrm{H}_{3}\right)$, 1.76-1.72 (m, $\left.1 \mathrm{H}, 1 \times \mathrm{H}_{1}\right), 1.39-1.37\left(\mathrm{~m}, 4 \mathrm{H}, 2 \times \mathrm{H}_{2}, 2 \times \mathrm{H}_{3}\right), 1.25\left(\right.$ br s, $\left.1 \mathrm{H}, 1 \times \mathrm{H}_{1}\right) .{ }^{13} \mathrm{C} \mathrm{NMR}(100$ $\left.\mathrm{MHz}, \mathrm{CDCl}_{3}\right) \delta 157.4(\mathrm{C}), 157.2(\mathrm{C}), 118.9(\mathrm{CH}), 43.8(\mathrm{CH}), 33.5\left(\mathrm{CH}_{2}\right), 26.6\left(\mathrm{CH}_{2}\right), 26.0\left(\mathrm{CH}_{2}\right), 24.4$ $\left(\mathrm{CH}_{3}\right)$.

${ }^{1} \mathrm{H}$ and ${ }^{13} \mathrm{C}$ NMR data for 4-cyclohexyl-2,6-dimethylpyridine (3c) prepared in this way were in agreement with those previously described. ${ }^{16}$ 
4-(3-Hexyl)-2,6-dimethylpyridine (3d; Table 2, entry 3)

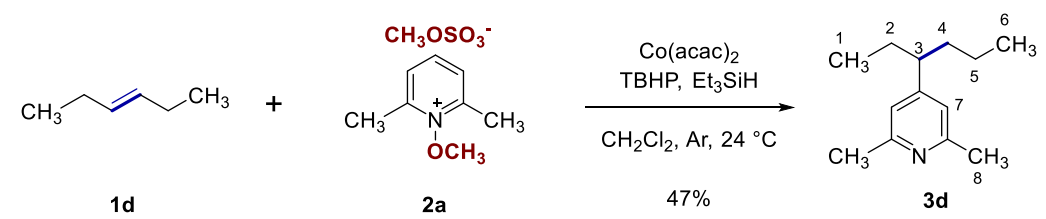

A 10-mL round-bottomed flask fitted with a rubber septum was charged sequentially with $\mathrm{N}$ methoxy 2,6-lutidinium methylsulfate (2a, $312 \mathrm{mg}, 1.25 \mathrm{mmol}, 5.00$ equiv) and cobalt bis(acetylacetonate) (64.3 mg, $250 \mu \mathrm{mol}, 1.00$ equiv). The reaction vessel was evacuated and refilled using a balloon of argon. This process was repeated twice. Dichloromethane $(1.25 \mathrm{~mL})$, trans-3-hexene $(\mathbf{1 d}, 31.8 \mu \mathrm{L}, 250 \mu \mathrm{mol}, 1$ equiv), triethylsilane ( $200 \mu \mathrm{L}, 1.25 \mathrm{mmol}, 5.00$ equiv), and a solution of tert-butyl hydroperoxide in nonane $(\sim 5.5 \mathrm{M}, 45.5 \mu \mathrm{L}, 250 \mu \mathrm{mol}, 1.00$ equiv) were added in sequence via syringe. The reaction vessel was protected from light with aluminum foil. The reaction mixture was stirred for $16 \mathrm{~h}$ at $24{ }^{\circ} \mathrm{C}$. The product mixture was transferred to a separatory funnel that had been charged with ethyl acetate $(100 \mathrm{~mL})$. The diluted product mixture was washed with $3 \mathrm{M}$ aqueous ammonium hydroxide solution $(3 \times 25 \mathrm{~mL})$. The organic layer was isolated and the isolated organic layer was dried over sodium sulfate. The dried solution was filtered and the filtrate was concentrated. The residue obtained was purified by flash-column chromatography (eluting with 5\% triethylamine-hexanes). The mixture obtained was further purified by automated flash-column chromatography (eluting with dichloromethane initially, grading to $10 \%$ methanol-dichloromethane, linear gradient) to afford 4-(3-hexyl)-2,6-dimethylpyridine (3d) as a colorless oil (22.7 mg, 47\%).

4-(3-Hexyl)-2,6-dimethylpyridine (3d): $\mathrm{R}_{f}=0.27$ (5\% triethylamine-hexanes; UV, CAM). ${ }^{1} \mathrm{H}$ NMR (400 $\left.\mathrm{MHz}, \mathrm{CDCl}_{3}\right) \delta 6.71\left(\mathrm{~s}, 2 \mathrm{H}, \mathrm{H}_{7}\right), 2.47\left(\mathrm{~s}, 6 \mathrm{H}, \mathrm{H}_{8}\right), 2.34-2.27\left(\mathrm{~m}, 1 \mathrm{H}, \mathrm{H}_{3}\right), 1.62-1.46\left(\mathrm{~m}, 4 \mathrm{H}, 2 \times \mathrm{H}_{2}, 2 \times\right.$ $\left.\mathrm{H}_{4}\right), 1.16-1.08\left(\mathrm{~m}, 2 \mathrm{H}, \mathrm{H}_{5}\right), 0.82\left(\mathrm{t}, \mathrm{J}=7.2 \mathrm{~Hz}, 3 \mathrm{H}, \mathrm{H}_{6}\right), 0.73\left(\mathrm{t}, \mathrm{J}=7.2 \mathrm{~Hz}, 3 \mathrm{H}, \mathrm{H}_{1}\right) .{ }^{13} \mathrm{C} \mathrm{NMR}(125 \mathrm{MHz}$, $\left.\mathrm{CDCl}_{3}\right) \delta 157.3(\mathrm{C}), 155.7(\mathrm{C}), 119.8(\mathrm{CH}), 47.1(\mathrm{CH}), 38.1\left(\mathrm{CH}_{2}\right), 29.0\left(\mathrm{CH}_{2}\right), 24.4\left(\mathrm{CH}_{3}\right), 20.6\left(\mathrm{CH}_{2}\right)$, $14.1\left(\mathrm{CH}_{3}\right), 12.0\left(\mathrm{CH}_{3}\right)$. IR (ATR-FTIR), cm ${ }^{-1}: 2958(\mathrm{~s}), 2929(\mathrm{~s}), 2873(\mathrm{~m}), 1605(\mathrm{~m}), 1567(\mathrm{~s}), 1457(\mathrm{~m})$, $862(\mathrm{~m}), 735(\mathrm{~m})$. HRMS-ESI (m/z): $[\mathrm{M}+\mathrm{H}]^{+}$calcd for $\mathrm{C}_{13} \mathrm{H}_{22} \mathrm{~N}, 192.1752$; found, 192.1756. 


\section{Benzyl 4-(2,6-dimethylpyridin-4-yl)-4-methylpiperidine-1-carboxylate (3e; Table 2, entry 5)}

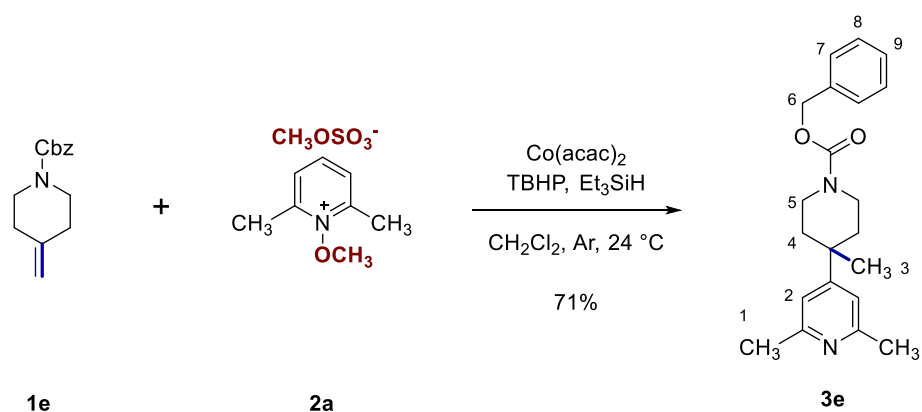

A $10-\mathrm{mL}$ round-bottomed flask fitted with a rubber septum was charged sequentially with benzyl 4-methylenepiperidine-1-carboxylate (1e, $48.1 \mathrm{mg}, 250 \mu \mathrm{mol}, 1$ equiv), $N$-methoxy 2,6-lutidinium methylsulfate (2a, $312 \mathrm{mg}, 1.25 \mathrm{mmol}, 5.00$ equiv), and cobalt bis(acetylacetonate) $(64.3 \mathrm{mg}, 250 \mu \mathrm{mol}$, 1.00 equiv). The reaction vessel was evacuated and refilled using a balloon of argon. This process was repeated twice. Dichloromethane $(1.25 \mathrm{~mL})$, triethylsilane $(200 \mu \mathrm{L}, 1.25 \mathrm{mmol}, 5.00$ equiv), and a solution of tert-butyl hydroperoxide in nonane $(\sim 5.5 \mathrm{M}, 45.5 \mu \mathrm{L}, 250 \mu \mathrm{mol}, 1.00$ equiv) were then added in sequence via syringe. The reaction vessel was protected from light with aluminum foil. The reaction mixture was stirred for $16 \mathrm{~h}$ at $24{ }^{\circ} \mathrm{C}$. The product mixture was transferred to a separatory funnel that had been charged with ethyl acetate $(100 \mathrm{~mL})$. The diluted product mixture was washed with $3 \mathrm{M}$ aqueous ammonium hydroxide solution $(3 \times 25 \mathrm{~mL})$. The organic layer was isolated and the isolated organic layer was dried over sodium sulfate. The dried solution was filtered and the filtrate was concentrated. The residue obtained was purified by flash-column chromatography (eluting with $15 \%$ acetone-10\% dichloromethane- $0.5 \%$ triethylamine-hexanes). The mixture obtained was further purified by flash-column chromatography (eluting with $10 \%$ ether-10\% dichloromethane-5\% triethylamine-hexanes) to afford benzyl 4-(2,6-dimethylpyridin-4-yl)-4-methylpiperidine-1-carboxylate (3e) as a colorless oil (67.0 mg, $71 \%)$.

Benzyl 4-(2,6-dimethylpyridin-4-yl)-4-methylpiperidine-1-carboxylate (3e): $\mathrm{R}_{f}=0.22$ (10\% ether-10\% dichloromethane-5\% triethylamine-hexanes; UV, CAM). ${ }^{1} \mathrm{H}$ NMR $\left(400 \mathrm{MHz}, \mathrm{CDCl}_{3}\right) \delta 7.37-7.27(\mathrm{~m}, 5 \mathrm{H}$, $\left.2 \times \mathrm{H}_{7}, 2 \times \mathrm{H}_{8}, 1 \times \mathrm{H}_{9}\right), 6.87\left(\mathrm{~s}, 2 \mathrm{H}, \mathrm{H}_{2}\right), 5.11\left(\mathrm{~s}, 2 \mathrm{H}, \mathrm{H}_{6}\right), 3.59-3.53\left(\mathrm{~m}, 2 \mathrm{H}, 2 \times \mathrm{H}_{4}\right), 3.44-3.39(\mathrm{~m}, 2 \mathrm{H}, 2$ $\left.\times \mathrm{H}_{4}\right), 2.50\left(\mathrm{~s}, 6 \mathrm{H}, \mathrm{H}_{1}\right), 2.03\left(\right.$ br s, $\left.2 \mathrm{H}, 2 \times \mathrm{H}_{5}\right), 1.65\left(\right.$ br s, $\left.2 \mathrm{H}, 2 \times \mathrm{H}_{5}\right), 1.22\left(\mathrm{~s}, 3 \mathrm{H}, \mathrm{H}_{3}\right) .{ }^{13} \mathrm{C} \mathrm{NMR}(100$ $\left.\mathrm{MHz}, \mathrm{CDCl}_{3}\right) \delta 157.9(\mathrm{C}), 157.5(\mathrm{C}), 155.3(\mathrm{C}), 136.8(\mathrm{C}), 128.4(\mathrm{CH}), 127.9(\mathrm{CH}), 127.8(\mathrm{CH}), 117.5$ $(\mathrm{CH}), 67.0\left(\mathrm{CH}_{2}\right), 40.6\left(\mathrm{CH}_{2}\right), 36.3\left(\mathrm{CH}_{2}\right), 36.1(\mathrm{C}), 28.3\left(\mathrm{CH}_{3}\right), 24.7\left(\mathrm{CH}_{3}\right)$. IR (ATR-FTIR), $\mathrm{cm}^{-1}: 2953$ (w), $1694(\mathrm{~s}), 1428(\mathrm{~m}), 1279$ (w), 1238 (s), $1186(\mathrm{~m}), 753(\mathrm{~m})$. HRMS-ESI (m/z): [M + H] $]^{+}$calcd for $\mathrm{C}_{21} \mathrm{H}_{27} \mathrm{~N}_{2} \mathrm{O}_{2}$, 339.2073; found, 339.2079. 


\section{3-(2,6-Dimethylpyridin-4-yl)-3-methylbutyl 4-methoxybenzoate (3f; Table 2, entry 6)}

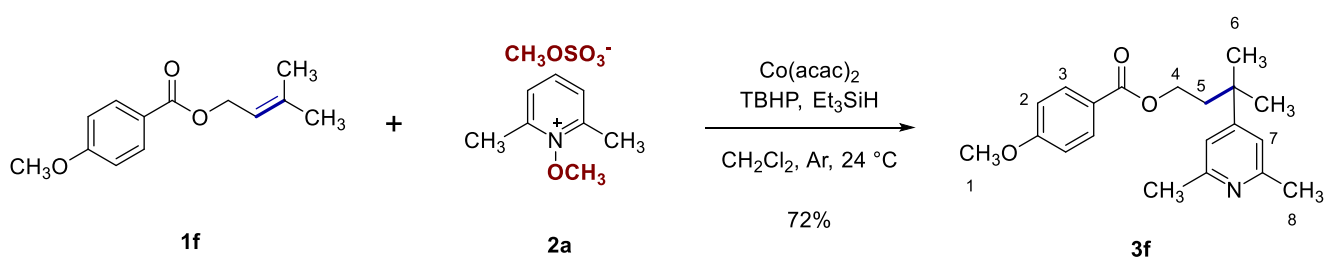

A $10-\mathrm{mL}$ round-bottomed flask fitted with a rubber septum was charged sequentially with 3methylbut-2-en-1-yl 4-methoxybenzoate (1f, $55.1 \mathrm{mg}, 250 \mu \mathrm{mol}, 1$ equiv), $N$-methoxy 2,6-lutidinium methylsulfate (2a, $312 \mathrm{mg}, 1.25 \mathrm{mmol}, 5.00$ equiv), and cobalt bis(acetylacetonate) $(64.3 \mathrm{mg}, 250 \mu \mathrm{mol}$, 1.00 equiv). The reaction vessel was evacuated and refilled using a balloon of argon. This process was repeated twice. Dichloromethane $(1.25 \mathrm{~mL})$, triethylsilane $(200 \mu \mathrm{L}, 1.25 \mathrm{mmol}, 5.00$ equiv), and a solution of tert-butyl hydroperoxide in nonane $(\sim 5.5 \mathrm{M}, 45.5 \mu \mathrm{L}, 250 \mu \mathrm{mol}, 1.00$ equiv) were then added in sequence via syringe. The reaction vessel was protected from light with aluminum foil. The reaction mixture was stirred for $16 \mathrm{~h}$ at $24{ }^{\circ} \mathrm{C}$. The product mixture was transferred to a separatory funnel that had been charged with ethyl acetate $(100 \mathrm{~mL})$. The diluted product mixture was washed with $3 \mathrm{M}$ aqueous ammonium hydroxide solution $(3 \times 25 \mathrm{~mL})$. The organic layer was isolated and the isolated organic layer was dried over sodium sulfate. The dried solution was filtered and the filtrate was concentrated. The residue obtained was purified by flash-column chromatography (eluting with $15 \%$ acetone-10\% dichloromethane- $0.5 \%$ triethylamine-hexanes). The mixture obtained was further purified by flash-column chromatography (eluting with $7.5 \%$ ether-10\% dichloromethane- $5 \%$ triethylamine-hexanes) to afford 3(2,6-dimethylpyridin-4-yl)-3-methylbutyl 4-methoxybenzoate (3f) as a colorless oil (59.2 $\mathrm{mg}, 72 \%)$.

3-(2,6-Dimethylpyridin-4-yl)-3-methylbutyl 4-methoxybenzoate $\quad(\mathbf{3 f}): \quad \mathrm{R}_{f}=0.14 \quad(7.5 \%$ ether-10\% dichloromethane-5\% triethylamine-hexanes; UV). ${ }^{1} \mathrm{H}$ NMR $\left(400 \mathrm{MHz}, \mathrm{CDCl}_{3}\right) \delta 7.73(\mathrm{~d}, \mathrm{~J}=8.4 \mathrm{~Hz}, 2 \mathrm{H}$, $\left.\mathrm{H}_{2}\right), 6.90\left(\mathrm{~s}, 2 \mathrm{H}, \mathrm{H}_{7}\right), 6.82\left(\mathrm{~d}, \mathrm{~J}=8.4 \mathrm{~Hz}, 2 \mathrm{H}, \mathrm{H}_{3}\right), 4.12\left(\mathrm{t}, \mathrm{J}=7.0 \mathrm{~Hz}, 2 \mathrm{H}, \mathrm{H}_{4}\right), 3.79\left(\mathrm{~s}, 3 \mathrm{H}, \mathrm{H}_{1}\right), 2.44(\mathrm{~s}, 6 \mathrm{H}$, $\left.\mathrm{H}_{8}\right), 2.07\left(\mathrm{t}, \mathrm{J}=6.8 \mathrm{~Hz}, 2 \mathrm{H}, \mathrm{H}_{5}\right), 1.32\left(\mathrm{~s}, 6 \mathrm{H}, \mathrm{H}_{6}\right) .{ }^{13} \mathrm{C} \mathrm{NMR}\left(100 \mathrm{MHz}, \mathrm{CDCl}_{3}\right) \delta 166.1(\mathrm{C}), 163.3(\mathrm{C})$, $158.2(\mathrm{C}), 157.5(\mathrm{C}), 131.3(\mathrm{CH}), 122.5(\mathrm{C}), 117.6(\mathrm{CH}), 113.4(\mathrm{CH}), 61.9\left(\mathrm{CH}_{2}\right), 55.3\left(\mathrm{CH}_{3}\right), 41.7\left(\mathrm{CH}_{2}\right)$, $36.4(\mathrm{C}), 28.5\left(\mathrm{CH}_{3}\right), 24.6\left(\mathrm{CH}_{3}\right)$. IR (ATR-FTIR), $\mathrm{cm}^{-1}$ : $2964(\mathrm{w}), 1707(\mathrm{~m}), 1604(\mathrm{~m}), 1273(\mathrm{~m}), 1252(\mathrm{~s})$, 1166 (s), 1101 (s), 1027 (m), 769 (m), 612 (m). HRMS-ESI (m/z): $[\mathrm{M}+\mathrm{H}]^{+}$calcd for $\mathrm{C}_{20} \mathrm{H}_{26} \mathrm{NO}_{3}$, 328.1913; found, 328.1932 . 


\section{2,6-Dimethyl-4-(3-methyl-1-phenylheptan-3-yl)pyridine (3g; Table 2, entry 7)}

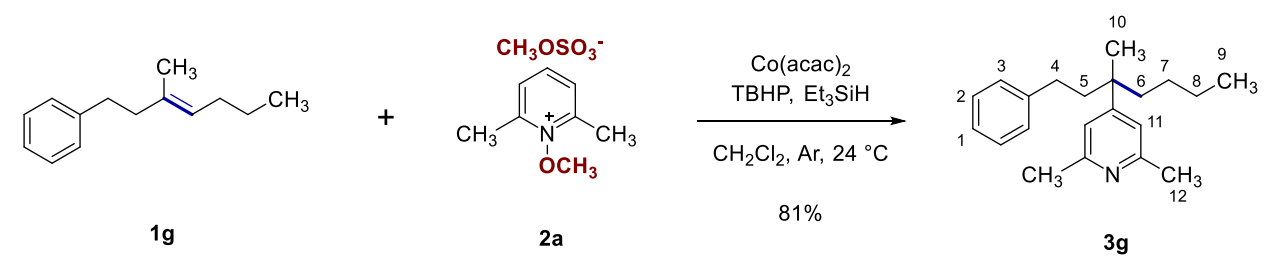

A $10-\mathrm{mL}$ round-bottomed flask fitted with a rubber septum was charged sequentially with $(E)-(3-$ methylhept-3-en-1-yl)benzene (1g, $47.1 \mathrm{mg}, 250 \mu \mathrm{mol}, 1$ equiv), $N$-methoxy 2,6-lutidinium methylsulfate (2a, $312 \mathrm{mg}, 1.25 \mathrm{mmol}, 5.00$ equiv), and cobalt bis(acetylacetonate) $(64.3 \mathrm{mg}, 250 \mu \mathrm{mol}, 1.00$ equiv). The reaction vessel was evacuated and refilled using a balloon of argon. This process was repeated twice. Dichloromethane $(1.25 \mathrm{~mL})$, triethylsilane $(200 \mu \mathrm{L}, 1.25 \mathrm{mmol}, 5.00$ equiv), and a solution of tert-butyl hydroperoxide in nonane $(\sim 5.5 \mathrm{M}, 45.5 \mu \mathrm{L}, 250 \mu \mathrm{mol}, 1.00$ equiv) were then added in sequence via syringe. The reaction vessel was protected from light with aluminum foil. The reaction mixture was stirred for $16 \mathrm{~h}$ at $24{ }^{\circ} \mathrm{C}$. The product mixture was transferred to a separatory funnel that had been charged with ethyl acetate $(100 \mathrm{~mL})$. The diluted product mixture was washed with $3 \mathrm{M}$ aqueous ammonium hydroxide solution $(3 \times 25 \mathrm{~mL})$. The organic layer was isolated and the isolated organic layer was dried over sodium sulfate. The dried solution was filtered and the filtrate was concentrated. The residue obtained was purified by flash-column chromatography (eluting with $5 \%$ triethylamine-hexanes). The mixture obtained was further purified by automated flash-column chromatography (eluting with dichloromethane initially, grading to $10 \%$ methanol-dichloromethane, linear gradient) to afford 2,6-dimethyl-4-(3-methyl-1phenylheptan-3-yl)pyridine (3g) as a colorless oil (60.0 $\mathrm{mg}, 81 \%)$.

2,6-Dimethyl-4-(3-methyl-1-phenylheptan-3-yl)pyridine (3g): $\mathrm{R}_{f}=0.24$ (5\% triethylamine-hexanes; $\mathrm{UV}$, CAM). ${ }^{1} \mathrm{H}$ NMR $\left(400 \mathrm{MHz}, \mathrm{CDCl}_{3}\right) \delta$ 7.27-7.23 (m, 2H, $\left.\mathrm{H}_{2}\right), 7.17-7.14\left(\mathrm{~m}, 1 \mathrm{H}, \mathrm{H}_{1}\right), 7.09-7.07(\mathrm{~m}, 2 \mathrm{H}$, $\left.\mathrm{H}_{3}\right), 6.90\left(\mathrm{~s}, 2 \mathrm{H}, \mathrm{H}_{11}\right), 2.53\left(\mathrm{~s}, 6 \mathrm{H}, \mathrm{H}_{12}\right), 2.43\left(\mathrm{td}, \mathrm{J}=13.0,5.2 \mathrm{~Hz}, 1 \mathrm{H}, 1 \times \mathrm{H}_{4}\right), 2.22(\mathrm{td}, \mathrm{J}=13.0,5.2 \mathrm{~Hz}$, $\left.1 \mathrm{H}, 1 \times \mathrm{H}_{4}\right), 1.95\left(\mathrm{td}, \mathrm{J}=13.0,5.2 \mathrm{~Hz}, 1 \mathrm{H}, 1 \times \mathrm{H}_{5}\right), 1.83\left(\mathrm{td}, \mathrm{J}=13.0,5.2 \mathrm{~Hz}, 1 \mathrm{H}, 1 \times \mathrm{H}_{5}\right), 1.68(\mathrm{td}, \mathrm{J}=$ 13.0, $\left.5.2 \mathrm{~Hz}, 1 \mathrm{H}, 1 \times \mathrm{H}_{6}\right), 1.55\left(\mathrm{td}, \mathrm{J}=13.0,5.2 \mathrm{~Hz}, 1 \mathrm{H}, 1 \times \mathrm{H}_{6}\right), 1.33\left(\mathrm{~s}, 3 \mathrm{H}, \mathrm{H}_{10}\right), 1.28-1.18\left(\mathrm{~m}, 2 \mathrm{H}, \mathrm{H}_{8}\right)$, $1.16-1.10\left(\mathrm{~m}, 1 \mathrm{H}, 1 \times \mathrm{H}_{7}\right), 0.99-0.92\left(\mathrm{~m}, 1 \mathrm{H}, 1 \times \mathrm{H}_{7}\right), 0.84\left(\mathrm{t}, \mathrm{J}=7.2 \mathrm{~Hz}, 3 \mathrm{H}, \mathrm{H}_{9}\right) .{ }^{13} \mathrm{C} \mathrm{NMR}(100 \mathrm{MHz}$, $\left.\mathrm{CDCl}_{3}\right) \delta 157.7(\mathrm{C}), 157.4(\mathrm{C}), 142.7(\mathrm{C}), 128.3(\mathrm{CH}), 128.2(\mathrm{CH}), 125.7(\mathrm{CH}), 118.3(\mathrm{CH}), 44.6\left(\mathrm{CH}_{2}\right)$, $42.4\left(\mathrm{CH}_{2}\right), 40.9(\mathrm{C}), 30.7\left(\mathrm{CH}_{2}\right), 26.3\left(\mathrm{CH}_{2}\right), 24.7\left(\mathrm{CH}_{3}\right), 23.3\left(\mathrm{CH}_{3}\right), 23.3\left(\mathrm{CH}_{2}\right), 14.0\left(\mathrm{CH}_{3}\right)$. IR (ATRFTIR), $\mathrm{cm}^{-1}: 2953(\mathrm{~m}), 2875(\mathrm{~m}), 1607(\mathrm{w}), 1458(\mathrm{w}), 1016$ (m), 843 (s), 723 (s), 698 (s). HRMS-ESI $(\mathrm{m} / \mathrm{z}):[\mathrm{M}+\mathrm{H}]^{+}$calcd for $\mathrm{C}_{21} \mathrm{H}_{30} \mathrm{~N}, 296.2378$; found, 296.2370 . 


\section{2,6-Dimethyl-4-(1-methylcyclohexyl)pyridine (3h; Table 2, entry 8)}

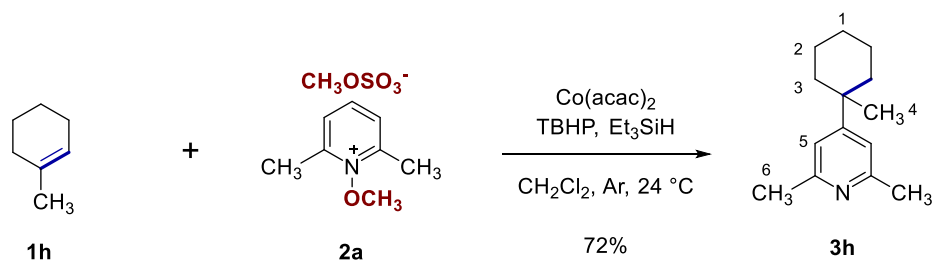

A 10-mL round-bottomed flask fitted with a rubber septum was charged sequentially with $\mathrm{N}$ methoxy 2,6-lutidinium methylsulfate (2a, $312 \mathrm{mg}, 1.25 \mathrm{mmol}, 5.00$ equiv) and cobalt bis(acetylacetonate) (64.3 mg, $250 \mu \mathrm{mol}, 1.00$ equiv). The reaction vessel was evacuated and refilled using a balloon of argon. This process was repeated twice. Dichloromethane $(1.25 \mathrm{~mL}), 1$-methylcyclohexene $(\mathbf{1 h}, 29.7 \mu \mathrm{L}, 250$ $\mu \mathrm{mol}, 1$ equiv), triethylsilane ( $200 \mu \mathrm{L}, 1.25 \mathrm{mmol}, 5.00$ equiv), and a solution of tert-butyl hydroperoxide in nonane $(\sim 5.5 \mathrm{M}, 45.5 \mu \mathrm{L}, 250 \mu \mathrm{mol}, 1.00$ equiv) were then added in sequence via syringe. The reaction vessel was protected from light with aluminum foil. The reaction mixture was stirred for $16 \mathrm{~h}$ at $24{ }^{\circ} \mathrm{C}$. The product mixture was transferred to a separatory funnel that had been charged with ethyl acetate (100 $\mathrm{mL})$. The diluted product mixture was washed with $3 \mathrm{M}$ aqueous ammonium hydroxide solution $(3 \times 25$ $\mathrm{mL}$ ). The organic layer was isolated and the isolated organic layer was dried over sodium sulfate. The dried solution was filtered and the filtrate was concentrated. The residue obtained was purified by flashcolumn chromatography (eluting with $5 \%$ triethylamine-hexanes). The mixture obtained was further purified by automated flash-column chromatography (eluting with dichloromethane initially, grading to $10 \%$ methanol-dichloromethane, linear gradient) to afford 2,6-dimethyl-4-(1-methylcyclohexyl)pyridine (3h) as a colorless oil (36.4 mg, $72 \%)$.

2,6-Dimethyl-4-(1-methylcyclohexyl)pyridine (3h): $\mathrm{R}_{f}=0.21$ (5\% triethylamine-hexanes; $\left.\mathrm{UV}, \mathrm{CAM}\right) .{ }^{1} \mathrm{H}$ $\operatorname{NMR}\left(400 \mathrm{MHz}, \mathrm{CDCl}_{3}\right) \delta 6.91\left(\mathrm{~s}, 2 \mathrm{H}, \mathrm{H}_{5}\right), 2.49\left(\mathrm{~s}, 6 \mathrm{H}, \mathrm{H}_{6}\right), 1.93-1.91\left(\mathrm{~m}, 2 \mathrm{H}, 2 \times \mathrm{H}_{3}\right), 1.54-1.49(\mathrm{~m}, 4 \mathrm{H}$, $\left.2 \times \mathrm{H}_{2}, 2 \times \mathrm{H}_{3}\right), 1.40$ (br s, $\left.4 \mathrm{H}, 2 \times \mathrm{H}_{1}, 2 \times \mathrm{H}_{2}\right), 1.12\left(\mathrm{~s}, 3 \mathrm{H}, \mathrm{H}_{4}\right) .{ }^{13} \mathrm{C} \mathrm{NMR}\left(100 \mathrm{MHz}, \mathrm{CDCl}_{3}\right) \delta 159.6(\mathrm{C})$, 157.4 (C), 117.8 (CH), 37.8 (C), 37.2 $\left(\mathrm{CH}_{2}\right), 29.9\left(\mathrm{CH}_{3}\right), 26.2\left(\mathrm{CH}_{2}\right), 24.6\left(\mathrm{CH}_{3}\right), 22.5\left(\mathrm{CH}_{2}\right)$. IR (ATRFTIR), $\mathrm{cm}^{-1}$ : 2932 (w), 2874 (m), 1605 (w), 1456(w), 1015 (w), 858 (s), 722 (s). HRMS-ESI (m/z): [M + $\mathrm{H}]^{+}$calcd for $\mathrm{C}_{14} \mathrm{H}_{22} \mathrm{~N}, 204.1752$; found, 204.1765. 
4-(2,3-Dimethylbutan-2-yl)-2,6-dimethylpyridine (3i; Table 2, entry 8)

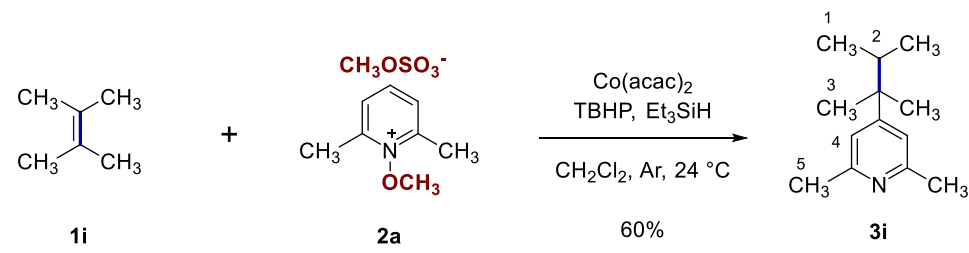

A 10-mL round-bottomed flask fitted with a rubber septum was charged sequentially with $N$ methoxy 2,6-lutidinium methylsulfate (2a, $312 \mathrm{mg}, 1.25 \mathrm{mmol}, 5.00$ equiv) and cobalt bis(acetylacetonate) (64.3 $\mathrm{mg}, 250 \mu \mathrm{mol}, 1.00$ equiv). The reaction vessel was evacuated and refilled using a balloon of argon. This process was repeated twice. Dichloromethane $(1.25 \mathrm{~mL}), 2$,3-dimethyl-2-butene $(\mathbf{1 i}, 29.7 \mu \mathrm{L}, 250$ $\mu \mathrm{mol}, 1$ equiv), triethylsilane ( $200 \mu \mathrm{L}, 1.25 \mathrm{mmol}, 5.00$ equiv), and a solution of tert-butyl hydroperoxide in nonane $(\sim 5.5 \mathrm{M}, 45.5 \mu \mathrm{L}, 250 \mu \mathrm{mol}, 1.00$ equiv) were then added in sequence via syringe. The reaction vessel was protected from light with aluminum foil. The reaction mixture was stirred for $16 \mathrm{~h}$ at $24{ }^{\circ} \mathrm{C}$. The product mixture was transferred to a separatory funnel that had been charged with ethyl acetate (100 $\mathrm{mL})$. The diluted product mixture was washed with $3 \mathrm{M}$ aqueous ammonium hydroxide solution $(3 \times 25$ $\mathrm{mL}$ ). The organic layer was isolated and the isolated organic layer was dried over sodium sulfate. The dried solution was filtered and the filtrate was concentrated. The residue obtained was purified by flashcolumn chromatography (eluting with 5\% triethylamine-hexanes). The mixture obtained was further purified by automated flash-column chromatography (eluting with dichloromethane initially, grading to $10 \%$ methanol-dichloromethane, linear gradient) to afford 4-(2,3-dimethylbutan-2-yl)-2,6dimethylpyridine (3i) as a colorless oil $(28.6 \mathrm{mg}, 60 \%)$.

4-(2,3-Dimethylbutan-2-yl)-2,6-dimethylpyridine (3i): $\mathrm{R}_{f}=0.21$ (5\% triethylamine-hexanes; UV, CAM). ${ }^{1} \mathrm{H}$ NMR $\left(400 \mathrm{MHz}, \mathrm{CDCl}_{3}\right) \delta 6.87\left(\mathrm{~s}, 2 \mathrm{H}, \mathrm{H}_{4}\right), 2.49\left(\mathrm{~s}, 6 \mathrm{H}, \mathrm{H}_{5}\right), 1.91-1.84\left(\mathrm{~m}, 1 \mathrm{H}, \mathrm{H}_{2}\right), 1.17\left(\mathrm{~s}, 6 \mathrm{H}, \mathrm{H}_{3}\right)$, $0.74\left(\mathrm{~d}, \mathrm{~J}=8.0 \mathrm{~Hz}, 6 \mathrm{H}, \mathrm{H}_{1}\right) .{ }^{13} \mathrm{C} \mathrm{NMR}\left(100 \mathrm{MHz}, \mathrm{CDCl}_{3}\right) \delta 160.0(\mathrm{C}), 157.0(\mathrm{C}), 118.1(\mathrm{CH}), 40.4(\mathrm{C})$, $37.6(\mathrm{CH}), 24.6\left(\mathrm{CH}_{3}\right), 24.0\left(\mathrm{CH}_{3}\right), 17.8\left(\mathrm{CH}_{3}\right)$. IR (ATR-FTIR), $\mathrm{cm}^{-1}: 2955(\mathrm{~m}), 1609(\mathrm{w}), 1459(\mathrm{w})$, $1016(\mathrm{~m}), 847(\mathrm{~s}), 723(\mathrm{~s}), 677(\mathrm{~m})$. HRMS-ESI $(\mathrm{m} / \mathrm{z})$ : $[\mathrm{M}+\mathrm{H}]^{+}$calcd for $\mathrm{C}_{13} \mathrm{H}_{22} \mathrm{~N}, 192.1756$; found, 192.1756. 


\section{2-Methyl-2-(pyridin-4-yl)propyl 4-methoxybenzoate (3j; Table 3)}

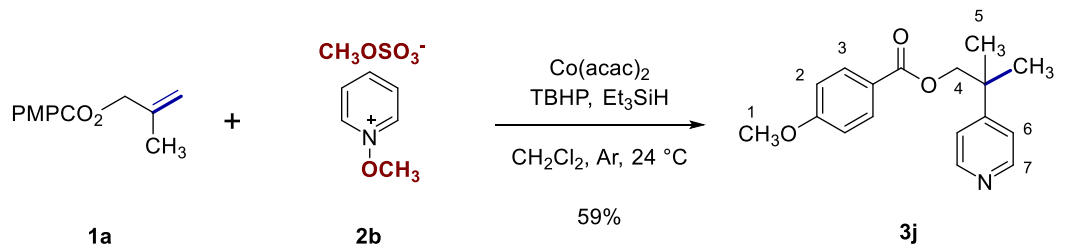

A 10-mL round-bottomed flask fitted with a rubber septum was charged sequentially with 2methylallyl 4-methoxybenzoate (1a, $51.6 \mathrm{mg}, 250 \mu \mathrm{mol}, 1$ equiv), $N$-methoxy pyridinium methylsulfate (2b, $277 \mathrm{mg}, 1.25 \mathrm{mmol}, 5.00$ equiv), and cobalt bis(acetylacetonate) (64.3 mg, $250 \mu \mathrm{mol}, 1.00 \mathrm{equiv})$. The reaction vessel was evacuated and refilled using a balloon of argon. This process was repeated twice. Dichloromethane $(1.25 \mathrm{~mL})$, triethylsilane $(200 \mu \mathrm{L}, 1.25 \mathrm{mmol}, 5.00$ equiv), and a solution of tert-butyl hydroperoxide in nonane $(\sim 5.5 \mathrm{M}, 45.5 \mu \mathrm{L}, 250 \mu \mathrm{mol}, 1.00$ equiv) were then added in sequence via syringe. The reaction vessel was protected from light with aluminum foil. The reaction mixture was stirred for $16 \mathrm{~h}$ at $24{ }^{\circ} \mathrm{C}$. The product mixture was transferred to a separatory funnel that had been charged with ethyl acetate $(100 \mathrm{~mL})$. The diluted product mixture was washed with $3 \mathrm{M}$ aqueous ammonium hydroxide solution $(3 \times 25 \mathrm{~mL})$. The organic layer was isolated and the isolated organic layer was dried over sodium sulfate. The dried solution was filtered and the filtrate was concentrated. The residue obtained was purified by flash-column chromatography (eluting with $15 \%$ acetone-10\% dichloromethane- $0.5 \%$ triethylamine-hexanes). The mixture obtained was further purified by flash-column chromatography (eluting with $7.5 \%$ ether-10\% dichloromethane-5\% triethylamine-hexanes). The mixture obtained was further purified by automated flash-column chromatography (eluting with 5\% ether-10\% dichloromethane$3 \%$ triethylamine-hexanes) to afford 2-methyl-2-(pyridin-4-yl)propyl 4-methoxybenzoate (3j) as a colorless oil (41.8 mg, 59\%).

The molar absorptivities of 4-tert-butylpyridine and isobutyl $p$-methoxybenzoate in methanol at $273 \mathrm{nM}$ were determined to be 45.9 and 25316, respectively. The ratio of isomers by LC/MS analysis at $273 \mathrm{nM}$ was therefore approximated as 4.7:1. This ratio is supported by the scale-up experiment shown in Figure 1, where both isomers were isolated separately (see below).

2-Methyl-2-(pyridin-4-yl)propyl 4-methoxybenzoate (3j): $\mathrm{R}_{f}=0.55$ (10\% methanol-dichloromethane; UV). ${ }^{1} \mathrm{H} \mathrm{NMR}\left(400 \mathrm{MHz}, \mathrm{CDCl}_{3}\right) \delta 8.36\left(\mathrm{br} \mathrm{s}, 2 \mathrm{H}, \mathrm{H}_{7}\right), 7.85\left(\mathrm{~d}, \mathrm{~J}=8.8 \mathrm{~Hz}, 2 \mathrm{H}, \mathrm{H}_{2}\right), 7.33\left(\mathrm{~d}, \mathrm{~J}=5.2 \mathrm{~Hz}, 2 \mathrm{H}, \mathrm{H}_{6}\right)$, $6.87\left(\mathrm{~d}, \mathrm{~J}=8.8 \mathrm{~Hz}, 2 \mathrm{H}, \mathrm{H}_{3}\right), 4.35\left(\mathrm{~s}, 2 \mathrm{H}, \mathrm{H}_{4}\right), 3.83\left(\mathrm{~s}, 3 \mathrm{H}, \mathrm{H}_{1}\right), 1.43\left(\mathrm{~s}, 6 \mathrm{H}, \mathrm{H}_{5}\right) .{ }^{13} \mathrm{C} \mathrm{NMR}(100 \mathrm{MHz}$, $\left.\mathrm{CDCl}_{3}\right) \delta 166.0(\mathrm{C}), 163.4(\mathrm{C}), 155.4(\mathrm{C}), 149.9(\mathrm{CH}), 131.5(\mathrm{CH}), 122.2(\mathrm{C}), 121.3(\mathrm{CH}), 113.6(\mathrm{CH})$, $72.1\left(\mathrm{CH}_{2}\right), 55.4\left(\mathrm{CH}_{3}\right), 38.5(\mathrm{C}), 25.4\left(\mathrm{CH}_{3}\right)$. IR (ATR-FTIR), $\mathrm{cm}^{-1}: 2970(\mathrm{w}), 1709(\mathrm{~m}), 1605(\mathrm{~m}), 1271$ $(\mathrm{m}), 1254(\mathrm{~s}), 1166(\mathrm{~m}), 1101(\mathrm{~m}), 769(\mathrm{~m})$. HRMS-ESI $(\mathrm{m} / \mathrm{z})$ : $[\mathrm{M}+\mathrm{H}]^{+}$calcd for $\mathrm{C}_{17} \mathrm{H}_{20} \mathrm{NO}_{3}, 286.1443$; found, 286.1434. 


\section{2-(1-((4-Methoxybenzyl)oxy)propan-2-yl)-4-methylpyridine (3k; Table 3)}

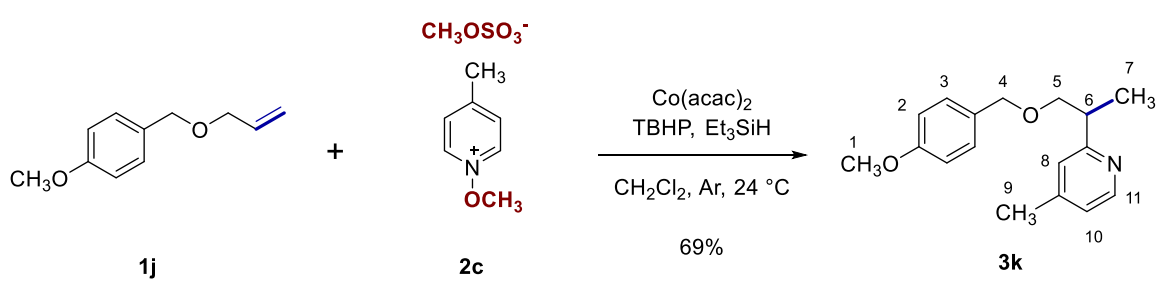

A $10-\mathrm{mL}$ round-bottomed flask fitted with a rubber septum was charged sequentially with allyl $p$ methoxybenzyl ether $(\mathbf{1 j}, 44.6 \mathrm{mg}, 250 \mu \mathrm{mol}, 1$ equiv), $N$-methoxy 4-picolinium methylsulfate (2c, $294 \mathrm{mg}$, $1.25 \mathrm{mmol}, 5.00$ equiv), and cobalt bis(acetylacetonate) $(64.3 \mathrm{mg}, 250 \mu \mathrm{mol}, 1.00$ equiv). The reaction vessel was evacuated and refilled using a balloon of argon. This process was repeated twice. Dichloromethane $(1.25 \mathrm{~mL})$, triethylsilane $(200 \mu \mathrm{L}, 1.25 \mathrm{mmol}, 5.00$ equiv), and a solution of tert-butyl hydroperoxide in nonane $(\sim 5.5 \mathrm{M}, 45.5 \mu \mathrm{L}, 250 \mu \mathrm{mol}, 1.00$ equiv) were then added in sequence via syringe. The reaction vessel was protected from light with aluminum foil. The reaction mixture was stirred for $16 \mathrm{~h}$ at $24{ }^{\circ} \mathrm{C}$. The product mixture was transferred to a separatory funnel that had been charged with ethyl acetate $(100 \mathrm{~mL})$. The diluted product mixture was washed with $3 \mathrm{M}$ aqueous ammonium hydroxide solution $(3 \times 25 \mathrm{~mL})$. The organic layer was isolated and the isolated organic layer was dried over sodium sulfate. The dried solution was filtered and the filtrate was concentrated. The residue obtained was purified by flash-column chromatography (eluting with $15 \%$ acetone-10\% dichloromethane- $0.5 \%$ triethylamine-hexanes). The mixture obtained was further purified by flash-column chromatography (eluting with $5 \%$ ether-10\% dichloromethane- $2.5 \%$ triethylamine-hexanes). The mixture obtained was further purified by automated flash-column chromatography (eluting with $2.5 \%$ ether-10\% dichloromethane- $0.5 \%$ triethylamine-hexanes) to afford 2-(1-((4-methoxybenzyl)oxy)propan-2-yl)-4methylpyridine (3k) as a colorless oil (47.1 $\mathrm{mg}, 69 \%)$.

2-(1-((4-Methoxybenzyl)oxy)propan-2-yl)-4-methylpyridine $\quad(3 \mathbf{k}): \quad \mathrm{R}_{f}=0.25 \quad(5 \%$ ether-10\% dichloromethane-2.5\% triethylamine-hexanes; UV, CAM). ${ }^{1} \mathrm{H} \mathrm{NMR}\left(400 \mathrm{MHz}, \mathrm{CDCl}_{3}\right) \delta 8.39(\mathrm{br} \mathrm{s}, 1 \mathrm{H}$, $\left.\mathrm{H}_{11}\right), 7.17\left(\mathrm{~d}, \mathrm{~J}=8.4 \mathrm{~Hz}, 2 \mathrm{H}, \mathrm{H}_{3}\right), 6.98\left(\mathrm{br} \mathrm{s}, 1 \mathrm{H}, \mathrm{H}_{8}\right), 6.93\left(\mathrm{~d}, \mathrm{~J}=4.4 \mathrm{~Hz}, 1 \mathrm{H}, \mathrm{H}_{10}\right), 6.83(\mathrm{~d}, \mathrm{~J}=8.4 \mathrm{Jz}, 2 \mathrm{H}$, $\left.\mathrm{H}_{2}\right), 4.42\left(\mathrm{~s}, 2 \mathrm{H}, \mathrm{H}_{4}\right), 3.76\left(\mathrm{~s}, 3 \mathrm{H}, \mathrm{H}_{1}\right), 3.73\left(\mathrm{t}, \mathrm{J}=4.0 \mathrm{~Hz}, 1 \mathrm{H}, 1 \times \mathrm{H}_{5}\right), 3.58\left(\mathrm{t}, \mathrm{J}=4.0 \mathrm{~Hz}, 1 \mathrm{H}, 1 \times \mathrm{H}_{5}\right)$, 3.20-3.14 (m, 1H, $\left.\mathrm{H}_{6}\right), 2.31\left(\mathrm{~s}, 3 \mathrm{H}, \mathrm{H}_{9}\right), 1.29\left(\mathrm{~d}, \mathrm{~J}=6.8 \mathrm{~Hz}, 3 \mathrm{H}, \mathrm{H}_{7}\right) .{ }^{13} \mathrm{C} \mathrm{NMR}\left(100 \mathrm{MHz}, \mathrm{CDCl}_{3}\right) \delta 163.5$ $(\mathrm{C}), 159.0(\mathrm{C}), 148.9(\mathrm{CH}), 14.7(\mathrm{C}), 130.6(\mathrm{C}), 129.1(\mathrm{CH}), 123.3(\mathrm{CH}), 122.4(\mathrm{CH}), 113.6(\mathrm{CH}), 74.6$ $\left(\mathrm{CH}_{2}\right), 72.6\left(\mathrm{CH}_{2}\right), 55.2\left(\mathrm{CH}_{3}\right), 42.0(\mathrm{CH}), 21.1\left(\mathrm{CH}_{3}\right), 17.4\left(\mathrm{CH}_{3}\right)$. IR (ATR-FTIR), $\mathrm{cm}^{-1}: 2931(\mathrm{w}), 1605$ (m), $1513(\mathrm{~s}), 1457(\mathrm{~m}), 1246(\mathrm{~s}), 1070(\mathrm{~m}), 1035(\mathrm{~m}), 821(\mathrm{~m})$. HRMS-ESI (m/z): $[\mathrm{M}+\mathrm{H}]^{+}$calcd for $\mathrm{C}_{17} \mathrm{H}_{22} \mathrm{NO}_{2}$, 272.1651; found, 272.1641 . 


\section{2-Methyl-4-(1-methylcyclobutyl)pyridine (3l; Table 3)}

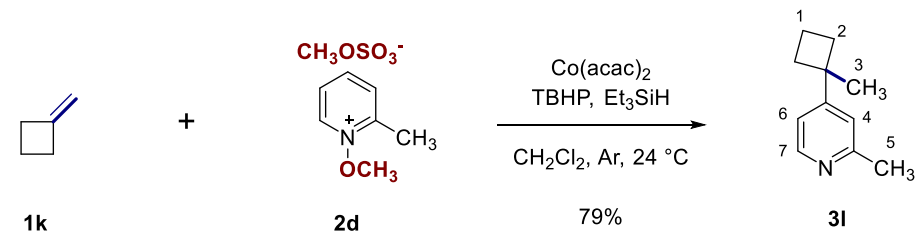

A 10-mL round-bottomed flask fitted with a rubber septum was charged sequentially with $N$ methoxy 2-picolinium methylsulfate (2d, $294 \mathrm{mg}, 1.25 \mathrm{mmol}, 5.00$ equiv) and cobalt bis(acetylacetonate) (64.3 mg, $250 \mu \mathrm{mol}, 1.00$ equiv). The reaction vessel was evacuated and refilled using a balloon of argon. This process was repeated twice. Dichloromethane $(1.25 \mathrm{~mL})$, methylenecyclobutane $(\mathbf{1 k}, 23.1 \mu \mathrm{L}, 250$ $\mu \mathrm{mol}, 1$ equiv), triethylsilane ( $200 \mu \mathrm{L}, 1.25 \mathrm{mmol}, 5.00$ equiv), and a solution of tert-butyl hydroperoxide in nonane $(\sim 5.5 \mathrm{M}, 45.5 \mu \mathrm{L}, 250 \mu \mathrm{mol}, 1.00$ equiv) were then added in sequence via syringe. The reaction vessel was protected from light with aluminum foil. The reaction mixture was stirred for $16 \mathrm{~h}$ at $24{ }^{\circ} \mathrm{C}$. The product mixture was transferred to a separatory funnel that had been charged with ethyl acetate (100 $\mathrm{mL})$. The diluted product mixture was washed with $3 \mathrm{M}$ aqueous ammonium hydroxide solution $(3 \times 25$ $\mathrm{mL}$ ). The organic layer was isolated and the isolated organic layer was dried over sodium sulfate. The dried solution was filtered and the filtrate was concentrated. The residue obtained was purified by flashcolumn chromatography (eluting with 5\% triethylamine-hexanes). The mixture obtained was further purified by automated flash-column chromatography (eluting with dichloromethane initially, grading to $10 \%$ methanol-dichloromethane, linear gradient) to afford 2-methyl-4-(1-methylcyclobutyl)pyridine (3I) as a colorless oil (31.9 mg, 79\%).

The molar absorbtivities of 2,4-dimetyl pyridine and 2,6-dimethyl pyridine in methanol are 2512 and 4367 at 265 and $267 \mathrm{nM}$, respectively. ${ }^{17}$ These values were therefore used to approximate the ratios of C-4 and C-2 isomers in the product. The calculated ratios by LC/MS analysis are 78:1.

2-Methyl-4-(1-methylcyclobutyl)pyridine (3I): $\mathrm{R}_{f}=0.33$ (10\% triethylamine-hexanes; UV, CAM). ${ }^{1} \mathrm{H}$ $\operatorname{NMR}\left(400 \mathrm{MHz}, \mathrm{CDCl}_{3}\right) \delta 8.37\left(\mathrm{~d}, \mathrm{~J}=5.2 \mathrm{~Hz}, 1 \mathrm{H}, \mathrm{H}_{7}\right), 6.92\left(\mathrm{~s}, 1 \mathrm{H}, \mathrm{H}_{4}\right), 6.87\left(\mathrm{~d}, \mathrm{~J}=4.8 \mathrm{~Hz}, 1 \mathrm{H}, \mathrm{H}_{6}\right), 2.52$ $\left(\mathrm{s}, 3 \mathrm{H}, \mathrm{H}_{5}\right), 2.36-2.30\left(\mathrm{~m}, 2 \mathrm{H}, 2 \times \mathrm{H}_{2}\right), 2.10-2.01\left(\mathrm{~m}, 3 \mathrm{H}, 1 \times \mathrm{H}_{1}, 2 \times \mathrm{H}_{2}\right), 1.85-1.80\left(\mathrm{~m}, 1 \mathrm{H}, 1 \times \mathrm{H}_{1}\right), 1.42$ $\left(\mathrm{s}, 3 \mathrm{H}, \mathrm{H}_{3}\right) .{ }^{13} \mathrm{C}$ NMR $\left(100 \mathrm{MHz}, \mathrm{CDCl}_{3}\right) \delta 161.2(\mathrm{C}), 158.1(\mathrm{C}), 148.9(\mathrm{CH}), 120.0(\mathrm{CH}), 117.4(\mathrm{CH})$, $42.3(\mathrm{C}), 33.6\left(\mathrm{CH}_{2}\right), 29.6\left(\mathrm{CH}_{3}\right), 24.5\left(\mathrm{CH}_{3}\right), 15.6\left(\mathrm{CH}_{2}\right)$. IR (ATR-FTIR), $\mathrm{cm}^{-1}: 2954(\mathrm{~m}), 2874(\mathrm{~m})$, $1607(\mathrm{~m}), 1006(\mathrm{~m}), 835(\mathrm{~s}), 723(\mathrm{~s})$. HRMS-ESI $(\mathrm{m} / \mathrm{z}):[\mathrm{M}+\mathrm{H}]^{+}$calcd for $\mathrm{C}_{11} \mathrm{H}_{16} \mathrm{~N}, 162.1283$; found, 162.1293 . 
6-(4-(Benzyloxy)pyridin-2-yl)-N-methoxy-N-methylheptanamide (3m; Table 3)

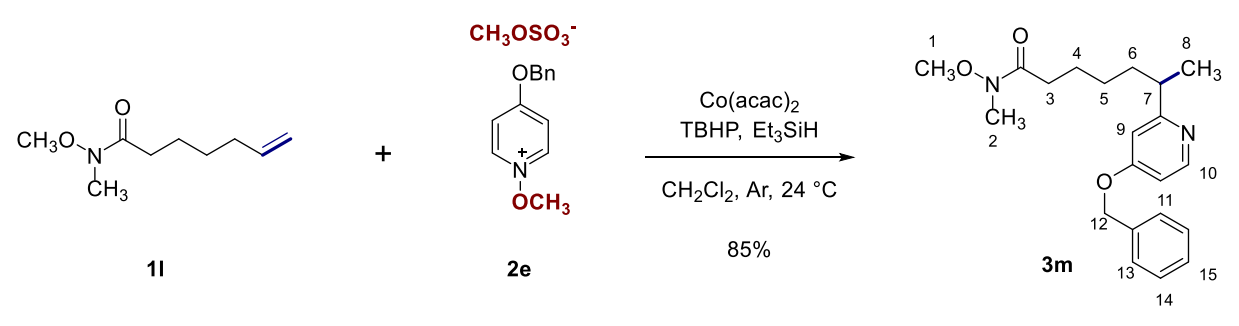

A $10-\mathrm{mL}$ round-bottomed flask fitted with a rubber septum was charged sequentially with $\mathrm{N}$ methoxy- $N$-methylhept-6-enamide (11, $42.8 \mathrm{mg}, 250 \mu \mathrm{mol}, 1$ equiv), $N$-methoxy 4-benzyloxypyridinium methylsulfate (2e, $409 \mathrm{mg}, 1.25 \mathrm{mmol}, 5.00$ equiv), and cobalt bis(acetylacetonate) $(64.3 \mathrm{mg}, 250 \mu \mathrm{mol}$, 1.00 equiv). The reaction vessel was evacuated and refilled using a balloon of argon. This process was repeated twice. Dichloromethane $(1.25 \mathrm{~mL})$, triethylsilane $(200 \mu \mathrm{L}, 1.25 \mathrm{mmol}, 5.00$ equiv), and a solution of tert-butyl hydroperoxide in nonane $(\sim 5.5 \mathrm{M}, 45.5 \mu \mathrm{L}, 250 \mu \mathrm{mol}, 1.00$ equiv) were then added in sequence via syringe. The reaction vessel was protected from light with aluminum foil. The reaction mixture was stirred for $16 \mathrm{~h}$ at $24^{\circ} \mathrm{C}$. The product mixture was transferred to a separatory funnel that had been charged with ethyl acetate $(100 \mathrm{~mL})$. The diluted product mixture was washed with $3 \mathrm{M}$ aqueous ammonium hydroxide solution $(3 \times 25 \mathrm{~mL})$. The organic layer was isolated and the isolated organic layer was dried over sodium sulfate. The dried solution was filtered and the filtrate was concentrated. The residue obtained was purified by flash-column chromatography (eluting with 15\% acetone-10\% dichloromethane- $0.5 \%$ triethylamine-hexanes, isocratic; then $10 \%$ methanol-dichloromethane). The mixture obtained was further purified by automated flash-column chromatography (eluting with dichloromethane initially, grading to $10 \%$ methanol-dichloromethane, linear gradient) to afford 6-(4(benzyloxy)pyridin-2-yl)- $N$-methoxy- $N$-methylheptanamide (3m) as a colorless oil (75.6 $\mathrm{mg}, 85 \%$ ).

6-(4-(Benzyloxy)pyridin-2-yl)- $N$-methoxy- $N$-methylheptanamide $\quad(\mathbf{3 m}): \quad \mathrm{R}_{f}=0.65 \quad(10 \%$ methanoldichloromethane; $\left.\mathrm{UV}, \mathrm{KMnO}_{4}\right) .{ }^{1} \mathrm{H} \mathrm{NMR}\left(500 \mathrm{MHz}, \mathrm{CDCl}_{3}\right) \delta 8.31\left(\mathrm{~d}, \mathrm{~J}=6.0 \mathrm{~Hz}, 1 \mathrm{H}, \mathrm{H}_{10}\right), 7.37-7.26(\mathrm{~m}$, $\left.5 \mathrm{H}, 2 \times \mathrm{H}_{13}, 2 \times \mathrm{H}_{14}, 1 \times \mathrm{H}_{15}\right), 6.67-6.64\left(\mathrm{~m}, 2 \mathrm{H}, 1 \times \mathrm{H}_{9}, 1 \times \mathrm{H}_{11}\right), 5.03\left(\mathrm{~s}, 2 \mathrm{H}, \mathrm{H}_{12}\right), 3.58\left(\mathrm{~s}, 3 \mathrm{H}, \mathrm{H}_{1}\right), 3.09$ $\left(\mathrm{s}, 3 \mathrm{H}, \mathrm{H}_{2}\right), 2.79-2.75\left(\mathrm{~m}, 1 \mathrm{H}, \mathrm{H}_{7}\right), 2.34-2.30\left(\mathrm{~m}, 2 \mathrm{H}, \mathrm{H}_{3}\right), 1.72-1.67\left(\mathrm{~m}, 1 \mathrm{H}, 1 \times \mathrm{H}_{6}\right), 1.60-1.50(\mathrm{~m}, 3 \mathrm{H}, 2$ $\left.\times \mathrm{H}_{4}, 1 \times \mathrm{H}_{6}\right), 1.30-1.16\left(\mathrm{~m}, 5 \mathrm{H}, 2 \times \mathrm{H}_{5}, 3 \times \mathrm{H}_{8}\right) .{ }^{13} \mathrm{C} \mathrm{NMR}\left(125 \mathrm{MHz}, \mathrm{CDCl}_{3}\right) \delta 174.6(\mathrm{C}), 168.2(\mathrm{C})$, $165.1(\mathrm{C}), 150.4(\mathrm{CH}), 135.8(\mathrm{C}), 128.6(\mathrm{CH}), 128.3(\mathrm{CH}), 128.5(\mathrm{CH}), 108.3(\mathrm{CH}), 107.8(\mathrm{CH}), 69.6$ $\left(\mathrm{CH}_{2}\right), 61.1\left(\mathrm{CH}_{3}\right), 42.0(\mathrm{CH}), 36.7\left(\mathrm{CH}_{2}\right), 32.1\left(\mathrm{CH}_{3}\right), 31.8\left(\mathrm{CH}_{2}\right), 27.4\left(\mathrm{CH}_{2}\right), 24.6\left(\mathrm{CH}_{2}\right), 20.7\left(\mathrm{CH}_{3}\right)$. IR (ATR-FTIR), $\mathrm{cm}^{-1}: 2935$ (w), 1657 (s), 1592 (m), 1566 (s), 1455 (m), 1301 (m), 995 (s), 697 (s). HRMSESI $(\mathrm{m} / \mathrm{z}):[\mathrm{M}+\mathrm{H}]^{+}$calcd for $\mathrm{C}_{21} \mathrm{H}_{29} \mathrm{~N}_{2} \mathrm{O}_{3}, 357.2178$; found, 357.2197 . 


\section{2-(4-(Benzyloxy)pyridin-2-yl)propyl 4-methoxybenzoate (3n; Table 3)}

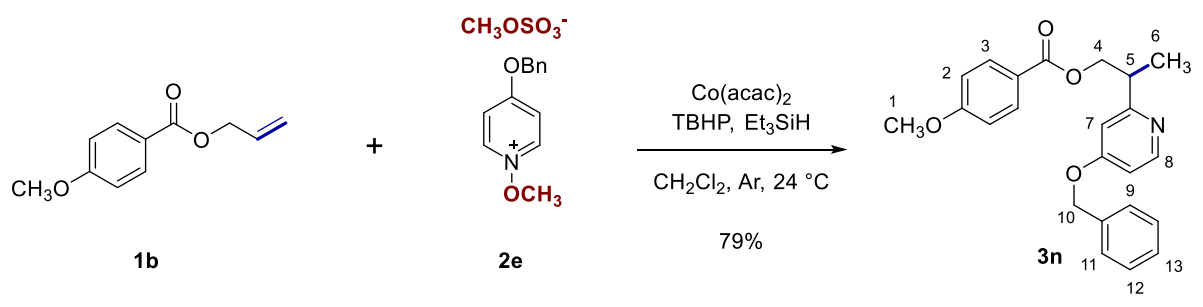

A 10-mL round-bottomed flask fitted with a rubber septum was charged sequentially with allyl 4methoxybenzoate (1b, $48.1 \mathrm{mg}, 250 \mu \mathrm{mol}, 1$ equiv), $N$-methoxy 4-benzyloxypyridinium methylsulfate (2e, $409 \mathrm{mg}, 1.25 \mathrm{mmol}, 5.00$ equiv), and cobalt bis(acetylacetonate) $(64.3 \mathrm{mg}, 250 \mu \mathrm{mol}, 1.00$ equiv). The reaction vessel was evacuated and refilled using a balloon of argon. This process was repeated twice. Dichloromethane $(1.25 \mathrm{~mL})$, triethylsilane $(200 \mu \mathrm{L}, 1.25 \mathrm{mmol}, 5.00$ equiv), and a solution of tert-butyl hydroperoxide in nonane $(\sim 5.5 \mathrm{M}, 45.5 \mu \mathrm{L}, 250 \mu \mathrm{mol}, 1.00$ equiv) were then added in sequence via syringe. The reaction vessel was protected from light with aluminum foil. The reaction mixture was stirred for $16 \mathrm{~h}$ at $24{ }^{\circ} \mathrm{C}$. The product mixture was transferred to a separatory funnel that had been charged with ethyl acetate $(100 \mathrm{~mL})$. The diluted product mixture was washed with $3 \mathrm{M}$ aqueous ammonium hydroxide solution $(3 \times 25 \mathrm{~mL})$. The organic layer was isolated and the isolated organic layer was dried over sodium sulfate. The dried solution was filtered and the filtrate was concentrated. The residue obtained was purified by flash-column chromatography (eluting with $15 \%$ acetone-10\% dichloromethane- $0.5 \%$ triethylamine-hexanes). The mixture obtained was further purified by automated flash-column chromatography (eluting with hexanes initially, grading to $20 \%$ ethyl acetate-hexanes, linear gradient) to afford 2-(4-(benzyloxy)pyridin-2-yl)propyl 4-methoxybenzoate (3n) as a colorless oil (74.5 mg, 79\%).

2-(4-(Benzyloxy)pyridin-2-yl)propyl 4-methoxybenzoate (3n): $\mathrm{R}_{f}=0.55$ (33\% ethyl acetate-hexanes; UV, CAM). ${ }^{1} \mathrm{H}$ NMR $\left(400 \mathrm{MHz}, \mathrm{CDCl}_{3}\right) \delta 8.40\left(\mathrm{br} \mathrm{s}, 1 \mathrm{H}, \mathrm{H}_{8}\right), 7.91\left(\mathrm{~d}, \mathrm{~J}=8.0 \mathrm{~Hz}, 2 \mathrm{H}, \mathrm{H}_{2}\right), 7.39-7.34(\mathrm{~m}, 5 \mathrm{H}$, $\left.2 \times \mathrm{H}_{11}, 2 \times \mathrm{H}_{12}, 1 \times \mathrm{H}_{13}\right), 6.87\left(\mathrm{~d}, \mathrm{~J}=8.4 \mathrm{~Hz}, 2 \mathrm{H}, \mathrm{H}_{3}\right), 6.82\left(\right.$ br s, $\left.1 \mathrm{H}, \mathrm{H}_{7}\right), 6.74\left(\mathrm{br} \mathrm{s}, 1 \mathrm{H}, \mathrm{H}_{9}\right), 5.06(\mathrm{~s}, 2 \mathrm{H}$, $\left.\mathrm{H}_{10}\right)$, 4.57-4.45 (m, 2H, H$), 3.83\left(\mathrm{~s}, 3 \mathrm{H}, \mathrm{H}_{1}\right), 3.37-3.27\left(\mathrm{~m}, 1 \mathrm{H}, \mathrm{H}_{5}\right), 1.39\left(\mathrm{~d}, \mathrm{~J}=6.8 \mathrm{~Hz}, 3 \mathrm{H}, \mathrm{H}_{6}\right) .{ }^{13} \mathrm{C}$ NMR (125 MHz, $\left.\mathrm{CDCl}_{3}\right) \delta 166.2(\mathrm{C}), 165.2(\mathrm{C}), 164.4(\mathrm{C}), 163.3(\mathrm{C}), 150.7(\mathrm{CH}), 135.7(\mathrm{C}), 131.6(\mathrm{CH})$, $128.7(\mathrm{CH}), 128.4(\mathrm{CH}), 127.5(\mathrm{CH}), 122.7(\mathrm{C}), 113.3(\mathrm{CH}), 109.1(\mathrm{CH}), 108.5(\mathrm{CH}), 69.7\left(\mathrm{CH}_{2}\right), 68.5$ $\left(\mathrm{CH}_{2}\right), 55.4\left(\mathrm{CH}_{3}\right) .41 .3(\mathrm{CH}), 17.1\left(\mathrm{CH}_{3}\right)$. IR (ATR-FTIR), $\mathrm{cm}^{-1}: 1707(\mathrm{~m}), 1591(\mathrm{~m}), 1567(\mathrm{~m}), 1273(\mathrm{~s})$, $1253(\mathrm{~s}), 1166(\mathrm{~m}), 1008(\mathrm{~s}), 695(\mathrm{~m})$. HRMS-ESI (m/z): $[\mathrm{M}+\mathrm{H}]^{+}$calcd for $\mathrm{C}_{23} \mathrm{H}_{24} \mathrm{NO}_{4}, 378.1705$; found, 378.1680 


\section{(R)-2-(8-Chloro-2,6-dimethyloctan-2-yl)isonicotinonitrile (3o; Table 3)}

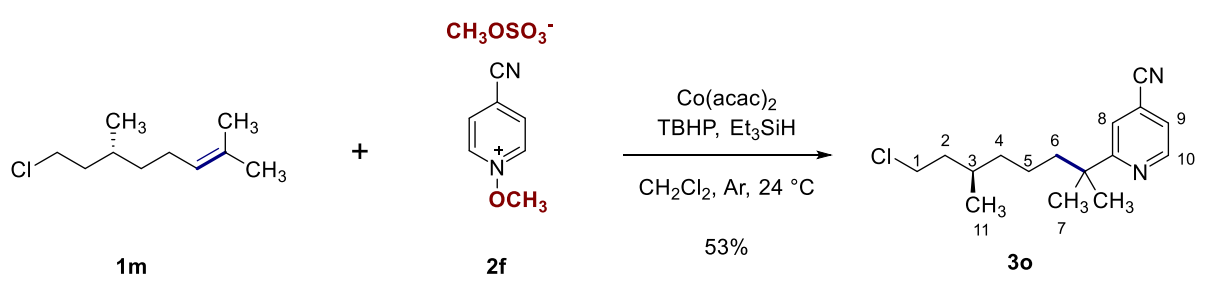

A $10-\mathrm{mL}$ round-bottomed flask fitted with a rubber septum was charged sequentially with $(R)$ citronellyl chloride $(\mathbf{1 m}, 43.7 \mathrm{mg}, 250 \mu \mathrm{mol}, 1$ equiv), $N$-methoxy 4-cyanopyridinium methylsulfate (2ff, $308 \mathrm{mg}, 1.25 \mathrm{mmol}, 5.00$ equiv), and cobalt bis(acetylacetonate) (64.3 mg, $250 \mu \mathrm{mol}, 1.00$ equiv). The reaction vessel was evacuated and refilled using a balloon of argon. This process was repeated twice. Dichloromethane $(1.25 \mathrm{~mL})$, triethylsilane $(200 \mu \mathrm{L}, 1.25 \mathrm{mmol}, 5.00$ equiv), and a solution of tert-butyl hydroperoxide in nonane $(\sim 5.5 \mathrm{M}, 45.5 \mu \mathrm{L}, 250 \mu \mathrm{mol}, 1.00$ equiv) were then added in sequence via syringe. The reaction vessel was protected from light with aluminum foil. The reaction mixture was stirred for $16 \mathrm{~h}$ at $24{ }^{\circ} \mathrm{C}$. The product mixture was transferred to a separatory funnel that had been charged with ethyl acetate $(100 \mathrm{~mL})$. The diluted product mixture was washed with $3 \mathrm{M}$ aqueous ammonium hydroxide solution $(3 \times 25 \mathrm{~mL})$. The organic layer was isolated and the isolated organic layer was dried over sodium sulfate. The dried solution was filtered and the filtrate was concentrated. The residue obtained was purified by flash-column chromatography (eluting with 5\% triethylamine-hexanes). The mixture obtained was further purified by automated flash-column chromatography (eluting with hexanes initially, grading to $33 \%$ ethyl acetate-hexanes, linear gradient) to afford $(R)$-2-(8-chloro-2,6-dimethyloctan-2yl)isonicotinonitrile (3o) as a colorless oil (37.1 mg, 53\%).

(R)-2-(8-Chloro-2,6-dimethyloctan-2-yl)isonicotinonitrile (3o): $\mathrm{R}_{f}=0.45$ (40\% ethyl acetate-hexanes; UV). ${ }^{1} \mathrm{H}$ NMR $\left(400 \mathrm{MHz}, \mathrm{CDCl}_{3}\right) \delta 8.72\left(\mathrm{~d}, \mathrm{~J}=4.8 \mathrm{~Hz}, 1 \mathrm{H}, \mathrm{H}_{10}\right), 7.49\left(\mathrm{~s}, 1 \mathrm{H}, \mathrm{H}_{9}\right), 7.30\left(\mathrm{~d}, \mathrm{~J}=4.8 \mathrm{~Hz}, 1 \mathrm{H}, \mathrm{H}_{8}\right)$, 3.55-3.44 (m, 2H, $\left.\mathrm{H}_{1}\right), 1.72-1.65\left(\mathrm{~m}, 3 \mathrm{H}, 2 \times \mathrm{H}_{2}, 1 \times \mathrm{H}_{3}\right), 1.60-1.45\left(\mathrm{~m}, 2 \mathrm{H}, \mathrm{H}_{5}\right), 1.33\left(\mathrm{~s}, 6 \mathrm{H}, \mathrm{H}_{7}\right), 1.27-$ $1.16\left(\mathrm{~m}, 1 \mathrm{H}, 1 \times \mathrm{H}_{4}\right), 1.10-1.00\left(\mathrm{~m}, 3 \mathrm{H}, 1 \times \mathrm{H}_{4}, 2 \times \mathrm{H}_{6}\right), 0.79\left(\mathrm{~d}, \mathrm{~J}=6.4 \mathrm{~Hz}, 3 \mathrm{H}, \mathrm{H}_{11}\right) .{ }^{13} \mathrm{C} \mathrm{NMR}(125$ $\left.\mathrm{MHz}, \mathrm{CDCl}_{3}\right) \delta 170.2(\mathrm{C}), 149.7(\mathrm{CH}), 121.9(\mathrm{CH}), 121.7(\mathrm{CH}), 120.3(\mathrm{C}), 117.1(\mathrm{C}), 43.2\left(\mathrm{CH}_{2}\right), 41.0(\mathrm{C})$, $39.7\left(\mathrm{CH}_{2}\right), 37.0\left(\mathrm{CH}_{2}\right), 30.1(\mathrm{CH}), 27.6\left(\mathrm{CH}_{3}\right), 27.5\left(\mathrm{CH}_{2}\right), 21.8\left(\mathrm{CH}_{2}\right), 18.9\left(\mathrm{CH}_{3}\right)$. IR (ATR-FTIR), $\mathrm{cm}^{-1}$ : 2960 (s), 2932 (s), 2872 (m), 2238 (m), 1591 (s), 1551 (s), 1470 (m), 1393 (m), 888 (m), 838 (s), 719 (s), 648 (s). HRMS-ESI $(\mathrm{m} / \mathrm{z}):[\mathrm{M}+\mathrm{H}]^{+}$calcd for $\mathrm{C}_{16} \mathrm{H}_{24} \mathrm{~N}_{2}{ }^{35 / 37} \mathrm{Cl}, 279.1628 / 281.1599$; found, 279.1623/281.1573. 


\section{2-(10-Fluorodecan-2-yl)-4-phenylpyridine (3p; Table 3)}

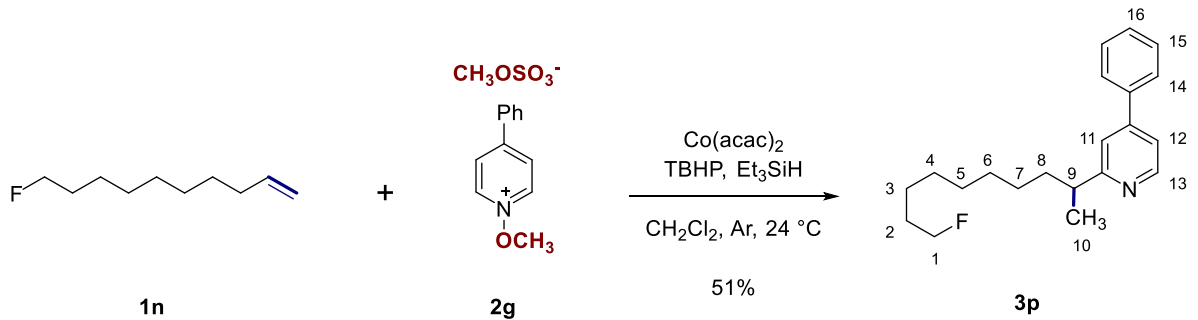

A $10-\mathrm{mL}$ round-bottomed flask fitted with a rubber septum was charged sequentially with 10 fluorodec-1-ene (1n, $39.6 \mathrm{mg}, 250 \mu \mathrm{mol}, 1$ equiv), $N$-methoxy 4-phenylpyridinium methylsulfate (2g, 372 $\mathrm{mg}, 1.25 \mathrm{mmol}, 5.00$ equiv), and cobalt bis(acetylacetonate) $(64.3 \mathrm{mg}, 250 \mu \mathrm{mol}, 1.00$ equiv). The reaction vessel was evacuated and refilled using a balloon of argon. This process was repeated twice. Dichloromethane $(1.25 \mathrm{~mL})$, triethylsilane $(200 \mu \mathrm{L}, 1.25 \mathrm{mmol}, 5.00$ equiv), and a solution of tert-butyl hydroperoxide in nonane $(\sim 5.5 \mathrm{M}, 45.5 \mu \mathrm{L}, 250 \mu \mathrm{mol}, 1.00$ equiv) were then added in sequence via syringe. The reaction vessel was protected from light with aluminum foil. The reaction mixture was stirred for $16 \mathrm{~h}$ at $24{ }^{\circ} \mathrm{C}$. The product mixture was transferred to a separatory funnel that had been charged with ethyl acetate $(100 \mathrm{~mL})$. The diluted product mixture was washed with $3 \mathrm{M}$ aqueous ammonium hydroxide solution $(3 \times 25 \mathrm{~mL})$. The organic layer was isolated and the isolated organic layer was dried over sodium sulfate. The dried solution was filtered and the filtrate was concentrated. The residue obtained was purified by flash-column chromatography (eluting with 5\% triethylamine-hexanes). The mixture obtained was further purified by automated flash-column chromatography (eluting with dichloromethane initially, grading to $10 \%$ methanol-dichloromethane, linear gradient) to afford 2-(10-fluorodecan-2-yl)-4phenylpyridine (3p) as a colorless oil $(39.9 \mathrm{mg}, 51 \%)$.

2-(10-Fluorodecan-2-yl)-4-phenylpyridine (3p): $\mathrm{R}_{f}=0.55$ (10\% methanol-dichloromethane; UV, CAM). ${ }^{1} \mathrm{H}$ NMR $\left(400 \mathrm{MHz}, \mathrm{CDCl}_{3}\right) \delta 8.58\left(\mathrm{~d}, \mathrm{~J}=5.3 \mathrm{~Hz}, 1 \mathrm{H}, \mathrm{H}_{13}\right), 7.64-7.62\left(\mathrm{~m}, 2 \mathrm{H}, \mathrm{H}_{15}\right), 7.48-7.43(\mathrm{~m}, 3 \mathrm{H}, 2 \times$ $\left.\mathrm{H}_{14}, 1 \times \mathrm{H}_{16}\right), 7.33-7.31\left(\mathrm{~m}, 2 \mathrm{H}, 1 \times \mathrm{H}_{11}, 1 \times \mathrm{H}_{12}\right), 4.41\left(\mathrm{dt}, \mathrm{J}(\mathrm{H}, \mathrm{F})=47.6 . \mathrm{J}(\mathrm{H}, \mathrm{H})=6.2 \mathrm{~Hz}, 2 \mathrm{H}, \mathrm{H}_{1}\right), 2.97-$ $2.89\left(\mathrm{~m}, 1 \mathrm{H}, \mathrm{H}_{9}\right), 1.82-1.74\left(\mathrm{~m}, 1 \mathrm{H}, 1 \times \mathrm{H}_{2}\right), 1.70-1.60\left(\mathrm{~m}, 3 \mathrm{H}, 1 \times \mathrm{H}_{2}, 2 \times \mathrm{H}_{8}\right), 1.34-1.16\left(\mathrm{~m}, 13 \mathrm{H}, 2 \times \mathrm{H}_{3}\right.$, $\left.2 \times \mathrm{H}_{4}, 2 \times \mathrm{H}_{5}, 2 \times \mathrm{H}_{6}, 2 \times \mathrm{H}_{7}, 3 \times \mathrm{H}_{10}\right) .{ }^{13} \mathrm{C} \mathrm{NMR}\left(100 \mathrm{MHz}, \mathrm{CDCl}_{3}\right) \delta 167.2(\mathrm{C}), 149.6(\mathrm{CH}), 148.7(\mathrm{C})$, $138.7(\mathrm{C}), 129.0(\mathrm{CH}), 128.8(\mathrm{CH}), 127.0(\mathrm{CH}), 119.5(\mathrm{CH}), 119.2(\mathrm{CH}), 85.0\left(\mathrm{CH}_{2}\right), 83.4\left(\mathrm{CH}_{2}\right), 42.2$ $(\mathrm{CH}), 37.2\left(\mathrm{CH}_{2}\right), 30.3\left(\mathrm{~J}=19.1 \mathrm{~Hz}, \mathrm{CH}_{2}\right), 29.4\left(\mathrm{~J}=21.1 \mathrm{~Hz}, \mathrm{CH}_{2}\right), 29.2\left(\mathrm{CH}_{2}\right), 27.6\left(\mathrm{CH}_{2}\right), 25.1(\mathrm{~J}=5.5$ $\left.\mathrm{Hz}, \mathrm{CH}_{2}\right), 20.9\left(\mathrm{CH}_{3}\right) .{ }^{19} \mathrm{~F} \mathrm{NMR}\left(375 \mathrm{MHz}, \mathrm{CDCl}_{3}\right) \delta-218.0$. IR (ATR-FTIR), $\mathrm{cm}^{-1}: 2958(\mathrm{~m}), 2927$ (s), $2854(\mathrm{~m}), 1596(\mathrm{~m}), 1547(\mathrm{~m}), 1474(\mathrm{~m}), 1001(\mathrm{w}), 762(\mathrm{~s}), 697(\mathrm{~m})$. HRMS-ESI (m/z): $[\mathrm{M}+\mathrm{H}]^{+}$calcd for $\mathrm{C}_{21} \mathrm{H}_{29} \mathrm{NF}, 314.2284$; found, 314.2271. 


\section{2-(4-Chloropyridin-2-yl)-2-methylpropyl 4-methoxybenzoate (3q; Table 3)}

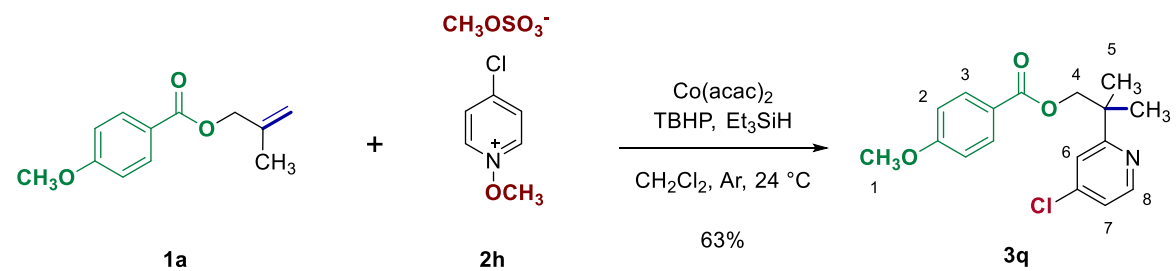

A $10-\mathrm{mL}$ round-bottomed flask fitted with a rubber septum was charged sequentially with 2 methylallyl 4-methoxybenzoate (1a, $51.6 \mathrm{mg}, 250 \mu \mathrm{mol}, 1$ equiv), $\mathrm{N}$-methoxy 4-chloropyridinium methylsulfate (2h, $320 \mathrm{mg}, 1.25 \mathrm{mmol}, 5.00$ equiv), and cobalt bis(acetylacetonate) (64.3 mg, $250 \mu \mathrm{mol}$, 1.00 equiv). The reaction vessel was evacuated and refilled using a balloon of argon. This process was repeated twice. Dichloromethane $(1.25 \mathrm{~mL})$, triethylsilane $(200 \mu \mathrm{L}, 1.25 \mathrm{mmol}, 5.00$ equiv), and a solution of tert-butyl hydroperoxide in nonane $(\sim 5.5 \mathrm{M}, 45.5 \mu \mathrm{L}, 250 \mu \mathrm{mol}, 1.00$ equiv) were then added in sequence via syringe. The reaction vessel was protected from light with aluminum foil. The reaction mixture was stirred for $16 \mathrm{~h}$ at $24{ }^{\circ} \mathrm{C}$. The product mixture was transferred to a separatory funnel that had been charged with ethyl acetate $(100 \mathrm{~mL})$. The diluted product mixture was washed with $3 \mathrm{M}$ aqueous ammonium hydroxide solution $(3 \times 25 \mathrm{~mL})$. The organic layer was isolated and the isolated organic layer was dried over sodium sulfate. The dried solution was filtered and the filtrate was concentrated. The residue obtained was purified by flash-column chromatography (eluting with 5\% ethyl acetate-10\% dichloromethane-5\% triethylamine-hexanes). The mixture obtained was further purified by automated flash-column chromatography (eluting with hexanes initially, grading to $20 \%$ ethyl acetate-hexanes, linear gradient) to afford 2-(4-chloropyridin-2-yl)-2-methylpropyl 4-methoxybenzoate (3q) as a colorless oil (50.1 mg, 63\%).

2-(4-Chloropyridin-2-yl)-2-methylpropyl 4-methoxybenzoate $(\mathbf{3 q}): \mathrm{R}_{f}=0.65$ (33\% ethyl acetate-hexanes; UV). ${ }^{1} \mathrm{H}$ NMR $\left(400 \mathrm{MHz}, \mathrm{CDCl}_{3}\right) \delta 8.47\left(\mathrm{~d}, \mathrm{~J}=5.0 \mathrm{~Hz}, 1 \mathrm{H}, \mathrm{H}_{8}\right), 7.85\left(\mathrm{~d}, \mathrm{~J}=8.5 \mathrm{~Hz}, 2 \mathrm{H}, \mathrm{H}_{2}\right), 7.39(\mathrm{~s}, 1 \mathrm{H}$, $\left.\mathrm{H}_{6}\right), 7.14\left(\mathrm{br} \mathrm{s}, 1 \mathrm{H}, \mathrm{H}_{7}\right), 6.86\left(\mathrm{~d}, \mathrm{~J}=8.5 \mathrm{~Hz}, 2 \mathrm{H}, \mathrm{H}_{3}\right), 4.48\left(\mathrm{~s}, 2 \mathrm{H}, \mathrm{H}_{4}\right), 3.82\left(\mathrm{~s}, 3 \mathrm{H}, \mathrm{H}_{1}\right), 1.46\left(\mathrm{~s}, 6 \mathrm{H}, \mathrm{H}_{5}\right)$. ${ }^{13} \mathrm{C}$ NMR $\left(125 \mathrm{MHz}, \mathrm{CDCl}_{3}\right) \delta 167.2(\mathrm{C}), 166.0(\mathrm{C}), 163.3(\mathrm{C}), 149.8(\mathrm{CH}), 144.2(\mathrm{C}), 131.5(\mathrm{CH}), 122.6$ $(\mathrm{C}), 121.6(\mathrm{CH}), 120.7(\mathrm{CH}), 113.6(\mathrm{CH}), 72.2\left(\mathrm{CH}_{2}\right), 55.4\left(\mathrm{CH}_{3}\right), 41.4(\mathrm{C}), 24.9\left(\mathrm{CH}_{3}\right)$. IR (ATR-FTIR), $\mathrm{cm}^{-1}$ : 2968 (w), 1709 (s), 1606 (m), 1573 (m), 1253 (s), 1166 (s), 1101 (m), 1030 (m), 847 (s), 769 (m). HRMS-ESI (m/z): $[\mathrm{M}+\mathrm{H}]^{+}$calcd for $\mathrm{C}_{17} \mathrm{H}_{18}{ }^{35} \mathrm{ClNO}_{3}$, 320.1053; found, 320.1066 . 


\section{(R)-2-(8-Bromo-2,6-dimethyloctan-2-yl)-4-chloropyridine (3r; Table 3)}

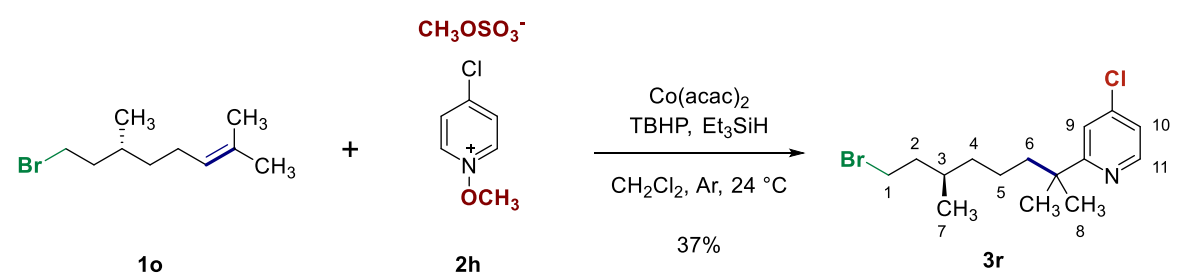

A 10-mL round-bottomed flask fitted with a rubber septum was charged sequentially with $(R)$ citronellyl bromide (1o, $54.8 \mathrm{mg}, 250 \mu \mathrm{mol}, 1$ equiv), $N$-methoxy 4-chloropyridinium methylsulfate $(\mathbf{2 h}$, $320 \mathrm{mg}, 1.25 \mathrm{mmol}, 5.00$ equiv), and cobalt bis(acetylacetonate) (64.3 mg, $250 \mu \mathrm{mol}, 1.00$ equiv). The reaction vessel was evacuated and refilled using a balloon of argon. This process was repeated twice. Dichloromethane $(1.25 \mathrm{~mL})$, triethylsilane $(200 \mu \mathrm{L}, 1.25 \mathrm{mmol}, 5.00$ equiv), and a solution of tert-butyl hydroperoxide in nonane $(\sim 5.5 \mathrm{M}, 45.5 \mu \mathrm{L}, 250 \mu \mathrm{mol}, 1.00$ equiv) were then added in sequence via syringe. The reaction vessel was protected from light with aluminum foil. The reaction mixture was stirred for $16 \mathrm{~h}$ at $24{ }^{\circ} \mathrm{C}$. The product mixture was transferred to a separatory funnel that had been charged with ethyl acetate $(100 \mathrm{~mL})$. The diluted product mixture was washed with $3 \mathrm{M}$ aqueous ammonium hydroxide solution $(3 \times 25 \mathrm{~mL})$. The organic layer was isolated and the isolated organic layer was dried over sodium sulfate. The dried solution was filtered and the filtrate was concentrated. The residue obtained was purified by flash-column chromatography (eluting with $20 \%$ ether-ethyl acetate). The mixture obtained was further purified by automated flash-column chromatography (eluting with hexanes initially, grading to $33 \%$ ether-hexanes, linear gradient) to afford (R)-2-(8-bromo-2,6-dimethyloctan-2-yl)-4-chloropyridine (3r) as a colorless oil $(30.9 \mathrm{mg}, 37 \%)$.

(R)-2-(8-Bromo-2,6-dimethyloctan-2-yl)-4-chloropyridine (3r): $\mathrm{R}_{f}=0.45$ (40\% ether-hexanes; UV, CAM). ${ }^{1} \mathrm{H}$ NMR $\left(400 \mathrm{MHz}, \mathrm{CDCl}_{3}\right) \delta 8.45\left(\mathrm{~d}, \mathrm{~J}=5.2 \mathrm{~Hz}, 1 \mathrm{H}, \mathrm{H}_{11}\right), 7.27\left(\mathrm{~d}, \mathrm{~J}=1.6 \mathrm{~Hz}, 1 \mathrm{H}, \mathrm{H}_{9}\right), 7.09(\mathrm{dd}, \mathrm{J}=5.2$, $\left.1.6 \mathrm{~Hz}, 1 \mathrm{H}, \mathrm{H}_{10}\right), 3.43-3.31\left(\mathrm{~m}, 2 \mathrm{H}, \mathrm{H}_{1}\right), 1.83-1.76\left(\mathrm{~m}, 1 \mathrm{H}, 1 \times \mathrm{H}_{4}\right), 1.69-1.63\left(\mathrm{~m}, 2 \mathrm{H}, \mathrm{H}_{2}\right), 1.61-1.53(\mathrm{~m}$, $\left.2 \mathrm{H}, 1 \times \mathrm{H}_{3}, 1 \times \mathrm{H}_{4}\right), 1.31\left(\mathrm{~s}, 3 \mathrm{H}, \mathrm{H}_{8}\right), 1.27-1.19\left(\mathrm{~m}, 1 \mathrm{H}, 1 \times \mathrm{H}_{5}\right), 1.09-1.03\left(\mathrm{~m}, 3 \mathrm{H}, 1 \times \mathrm{H}_{5}, 2 \times \mathrm{H}_{6}\right), 0.79(\mathrm{~d}$, $\left.\mathrm{J}=6.4 \mathrm{~Hz}, 2 \mathrm{H}, \mathrm{H}_{7}\right) .{ }^{13} \mathrm{C} \mathrm{NMR}\left(100 \mathrm{MHz}, \mathrm{CDCl}_{3}\right) \delta 170.3(\mathrm{C}), 149.6(\mathrm{CH}), 144.1(\mathrm{C}), 120.9(\mathrm{CH}), 120.4$ $(\mathrm{CH}), 43.3\left(\mathrm{CH}_{2}\right), 40.7(\mathrm{C}), 40.0\left(\mathrm{CH}_{2}\right), 37.0\left(\mathrm{CH}_{2}\right), 30.1\left(\mathrm{CH}_{2}\right), 31.4(\mathrm{CH}), 27.7\left(\mathrm{CH}_{3}\right), 27.7\left(\mathrm{CH}_{3}\right), 21.9$ $\left(\mathrm{CH}_{2}\right), 18.8\left(\mathrm{CH}_{3}\right)$. IR (ATR-FTIR), cm ${ }^{-1}: 2961(\mathrm{~m}), 2932(\mathrm{~m}), 1571(\mathrm{~s}), 1553(\mathrm{~s}), 1461(\mathrm{~m}), 1388(\mathrm{w})$, $1379(\mathrm{w}), 824(\mathrm{~m}), 698(\mathrm{~m})$. HRMS-ESI $(\mathrm{m} / \mathrm{z})$ : $[\mathrm{M}+\mathrm{H}]^{+}$calcd for $\mathrm{C}_{15} \mathrm{H}_{24}{ }^{79} \mathrm{Br}^{35} \mathrm{ClN}, 332.0781$; found, 332.0799 . 


\section{3-Methyl-3-(5-methylpyridin-2-yl)butyl 4-methoxybenzoate (3s; Table 3)}

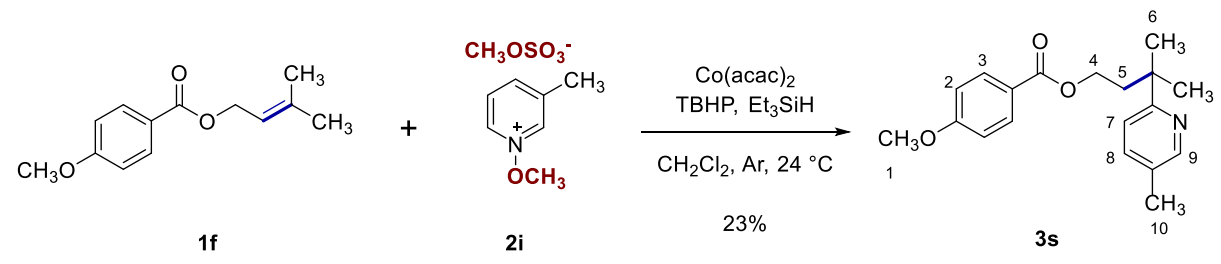

A 10-mL round-bottomed flask fitted with a rubber septum was charged sequentially with 3methylbut-2-en-1-yl 4-methoxybenzoate (1f, $55.1 \mathrm{mg}, 250 \mu \mathrm{mol}, 1$ equiv), $\mathrm{N}$-methoxy 3-methylpyridinium methylsulfate (2i, $294 \mathrm{mg}, 1.25 \mathrm{mmol}, 5.00$ equiv), and cobalt bis(acetylacetonate) $(64.3 \mathrm{mg}, 250 \mu \mathrm{mol}$, 1.00 equiv). The reaction vessel was evacuated and refilled using a balloon of argon. This process was repeated twice. Dichloromethane $(1.25 \mathrm{~mL})$, triethylsilane $(200 \mu \mathrm{L}, 1.25 \mathrm{mmol}, 5.00$ equiv), and a solution of tert-butyl hydroperoxide in nonane $(\sim 5.5 \mathrm{M}, 45.5 \mu \mathrm{L}, 250 \mu \mathrm{mol}, 1.00$ equiv) were then added in sequence via syringe. The reaction vessel was protected from light with aluminum foil. The reaction mixture was stirred for $16 \mathrm{~h}$ at $24{ }^{\circ} \mathrm{C}$. The product mixture was transferred to a separatory funnel that had been charged with ethyl acetate $(100 \mathrm{~mL})$. The diluted product mixture was washed with $3 \mathrm{M}$ aqueous ammonium hydroxide solution $(3 \times 25 \mathrm{~mL})$. The organic layer was isolated and the isolated organic layer was dried over sodium sulfate. The dried solution was filtered and the filtrate was concentrated. The residue obtained was purified by flash-column chromatography (eluting with $15 \%$ acetone-10\% dichloromethane- $0.5 \%$ triethylamine-hexanes). The mixture obtained was further purified by flashcolumn chromatography (eluting with $10 \%$ ether-10\% dichloromethane-5\% triethylamine-hexanes) to afford separately 3-methyl-3-(5-methylpyridin-2-yl)butyl 4-methoxybenzoate (3s, $17.9 \mathrm{mg}, 23 \%$, colorless oil) and 3-methylbut-2-en-1-yl 4-methoxybenzoate (1f, $28.6 \mathrm{mg}, 52 \%$, colorless oil).

3-Methyl-3-(5-methylpyridin-2-yl)butyl 4-methoxybenzoate $\quad(3 \mathrm{~s}): \quad \mathrm{R}_{f}=0.61 \quad(10 \%$ methanoldichloromethane; UV). ${ }^{1} \mathrm{H}$ NMR $\left(500 \mathrm{MHz}, \mathrm{CDCl}_{3}\right) \delta 8.37\left(\mathrm{~d}, \mathrm{~J}=2.0 \mathrm{~Hz}, 1 \mathrm{H}, \mathrm{H}_{9}\right), 7.83(\mathrm{~d}, \mathrm{~J}=8.5 \mathrm{~Hz}, 2 \mathrm{H}$, $\left.\mathrm{H}_{2}\right), 7.38\left(\mathrm{~d}, \mathrm{~J}=5.5 \mathrm{~Hz}, 1 \mathrm{H}, \mathrm{H}_{8}\right), 7.21\left(\mathrm{~d}, \mathrm{~J}=5.5 \mathrm{~Hz}, 1 \mathrm{H}, \mathrm{H}_{7}\right), 6.85\left(\mathrm{~d}, \mathrm{~J}=8.5 \mathrm{~Hz}, 2 \mathrm{H}, \mathrm{H}_{3}\right), 4.17(\mathrm{t}, \mathrm{J}=7.0$ $\left.\mathrm{Hz}, 2 \mathrm{H}, \mathrm{H}_{4}\right), 3.84\left(\mathrm{~s}, 3 \mathrm{H}, \mathrm{H}_{1}\right), 2.25-2.22\left(\mathrm{~m}, 5 \mathrm{H}, 2 \times \mathrm{H}_{5}, 3 \times \mathrm{H}_{10}\right), 1.42\left(\mathrm{~s}, 6 \mathrm{H}, \mathrm{H}_{6}\right) .{ }^{13} \mathrm{C} \mathrm{NMR}(125 \mathrm{MHz}$, $\left.\mathrm{CDCl}_{3}\right) \delta 166.3(\mathrm{C}), 164.2(\mathrm{C}), 163.1(\mathrm{C}), 149.2(\mathrm{CH}), 136.8(\mathrm{CH}), 131.5(\mathrm{CH}), 130.0(\mathrm{C}), 122.8(\mathrm{C}), 119.1$ $(\mathrm{CH}), 13.4(\mathrm{CH}), 62.3\left(\mathrm{CH}_{2}\right), 55.4\left(\mathrm{CH}_{3}\right), 41.2\left(\mathrm{CH}_{2}\right), 39.0(\mathrm{C}), 28.3\left(\mathrm{CH}_{3}\right), 17.9\left(\mathrm{CH}_{3}\right)$. IR (ATR-FTIR), $\mathrm{cm}^{-1}: 2962(\mathrm{w}), 1710(\mathrm{~m}), 1275(\mathrm{~m}), 1256(\mathrm{~s}), 1168(\mathrm{~m}), 1115(\mathrm{~m}), 1103(\mathrm{~m}), 1030(\mathrm{w})$. HRMS-ESI (m/z): $[\mathrm{M}+\mathrm{H}]^{+}$calcd for $\mathrm{C}_{19} \mathrm{H}_{24} \mathrm{NO}_{3}, 314.1756$; found, 314.1739 . 


\section{3-Methyl-3-(5-bromopyridin-2-yl)butyl 4-methoxybenzoate (3t; Table 3)}

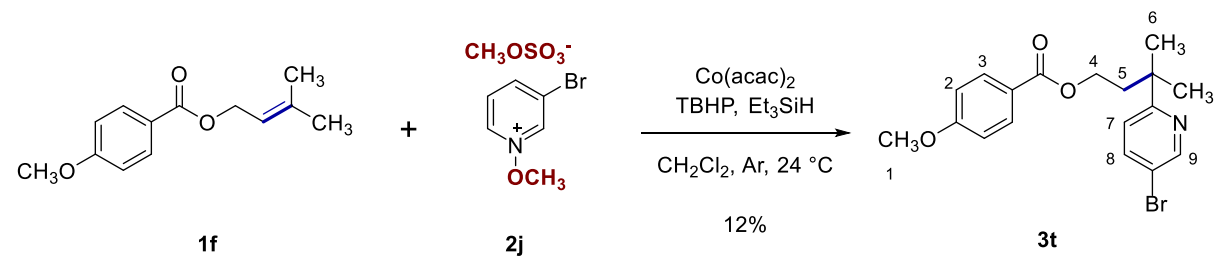

A 10-mL round-bottomed flask fitted with a rubber septum was charged sequentially with 3methylbut-2-en-1-yl 4-methoxybenzoate (1f, $55.1 \mathrm{mg}, 250 \mu \mathrm{mol}, 1$ equiv), $N$-methoxy 3-bromopyridinium methylsulfate (2j, $375 \mathrm{mg}, 1.25 \mathrm{mmol}, 5.00$ equiv), and cobalt bis(acetylacetonate) $(64.3 \mathrm{mg}, 250 \mu \mathrm{mol}$, 1.00 equiv). The reaction vessel was evacuated and refilled using a balloon of argon. This process was repeated twice. Dichloromethane $(1.25 \mathrm{~mL})$, triethylsilane $(200 \mu \mathrm{L}, 1.25 \mathrm{mmol}, 5.00$ equiv), and a solution of tert-butyl hydroperoxide in nonane $(\sim 5.5 \mathrm{M}, 45.5 \mu \mathrm{L}, 250 \mu \mathrm{mol}, 1.00$ equiv) were then added in sequence via syringe. The reaction vessel was protected from light with aluminum foil. The reaction mixture was stirred for $16 \mathrm{~h}$ at $24{ }^{\circ} \mathrm{C}$. The product mixture was transferred to a separatory funnel that had been charged with ethyl acetate $(100 \mathrm{~mL})$. The diluted product mixture was washed with $3 \mathrm{M}$ aqueous ammonium hydroxide solution $(3 \times 25 \mathrm{~mL})$. The organic layer was isolated and the isolated organic layer was dried over sodium sulfate. The dried solution was filtered and the filtrate was concentrated. The residue obtained was purified by flash-column chromatography (eluting with $15 \%$ acetone-10\% dichloromethane- $0.5 \%$ triethylamine-hexanes). The mixture obtained was further purified by flashcolumn chromatography (eluting with $10 \%$ ether-10\% dichloromethane-5\% triethylamine-hexanes) to afford separately 3-methyl-3-(5-bromopyridin-2-yl)butyl 4-methoxybenzoate (3t, $11.6 \mathrm{mg}, 12 \%$, yellow oil) and 3-methylbut-2-en-1-yl 4-methoxybenzoate (1f, $43.1 \mathrm{mg}, 78 \%$, colorless oil).

The molar absorptivities of 3-bromopyridine and isobutyl $p$-methoxybenzoate in methanol at 273 nM were determined to be 441 and 25316, respectively. Thus, the ratio of isomers was approximated by LC/MS analysis to be 5.3:1.

3-Methyl-3-(5-bromopyridin-2-yl)butyl 4-methoxybenzoate $(\mathbf{3 t}): \quad \mathrm{R}_{f}=0.54 \quad(10 \%$ methanoldichloromethane; UV). ${ }^{1} \mathrm{H}$ NMR $\left(500 \mathrm{MHz}, \mathrm{CDCl}_{3}\right) \delta 8.57\left(\mathrm{~d}, \mathrm{~J}=1.6 \mathrm{~Hz}, 1 \mathrm{H}, \mathrm{H}_{9}\right), 7.75(\mathrm{~d}, \mathrm{~J}=8.8 \mathrm{~Hz}, 2 \mathrm{H}$, $\left.\mathrm{H}_{2}\right), 7.66\left(\mathrm{dd}, \mathrm{J}=8.4,2.0 \mathrm{~Hz}, 1 \mathrm{H}, \mathrm{H}_{8}\right), 7.20\left(\mathrm{~d}, \mathrm{~J}=8.8 \mathrm{~Hz}, 1 \mathrm{H}, \mathrm{H}_{7}\right), 6.86\left(\mathrm{~d}, \mathrm{~J}=8.4 \mathrm{~Hz}, 2 \mathrm{H}, \mathrm{H}_{3}\right), 4.19(\mathrm{t}, \mathrm{J}=$ $\left.6.8 \mathrm{~Hz}, 2 \mathrm{H}, \mathrm{H}_{4}\right), 3.84\left(\mathrm{~s}, 3 \mathrm{H}, \mathrm{H}_{1}\right), 2.23\left(\mathrm{t}, \mathrm{J}=7.0 \mathrm{~Hz}, 2 \mathrm{H}, \mathrm{H}_{5}\right), 1.41\left(\mathrm{~s}, 6 \mathrm{H}, \mathrm{H}_{6}\right) .{ }^{13} \mathrm{C} \mathrm{NMR}(100 \mathrm{MHz}$, $\left.\mathrm{CDCl}_{3}\right) \delta 166.2(\mathrm{C}), 166.0(\mathrm{C}), 163.2(\mathrm{C}), 149.8(\mathrm{CH}), 138.7(\mathrm{CH}), 131.4(\mathrm{CH}), 122.6(\mathrm{C}), 121.2(\mathrm{CH})$, $117.8(\mathrm{C}), 113.5(\mathrm{CH}), 61.9\left(\mathrm{CH}_{2}\right), 55.4\left(\mathrm{CH}_{3}\right), 41.1\left(\mathrm{CH}_{2}\right), 39.3(\mathrm{C}), 28.2\left(\mathrm{CH}_{3}\right)$. IR (ATR-FTIR), $\mathrm{cm}^{-1}$ : $2964(\mathrm{w}), 1710$ (m), 1607 (m), 1461 (w), 1275 (m), 1257 (s), 1168 (m), $1115(\mathrm{~m}), 1103(\mathrm{~m})$. HRMS-ESI $(\mathrm{m} / \mathrm{z}):[\mathrm{M}+\mathrm{H}]^{+}$calcd for $\mathrm{C}_{18} \mathrm{H}_{21} \mathrm{~N}^{79 / 81} \mathrm{BrO}_{3}, 378.0705 / 380.0684$; found, 378.0737/380.0653. 


\section{Large scale hydropyridylation of 1a (Figure 1)}

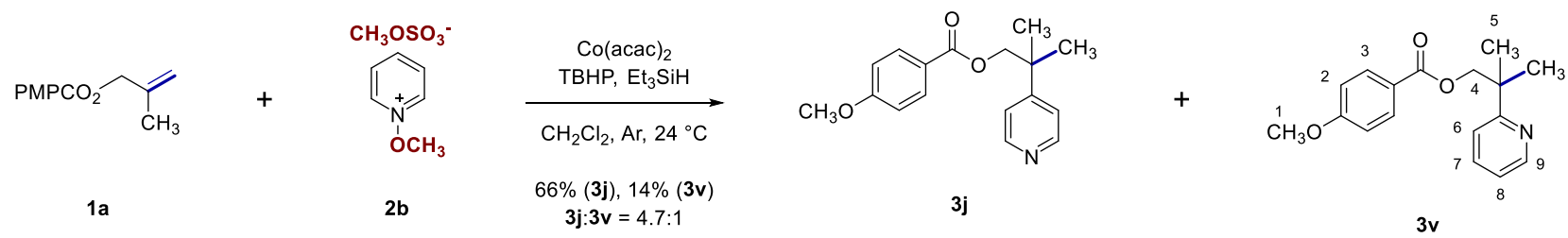

A $25-\mathrm{mL}$ round-bottomed flask fitted with a rubber septum was charged sequentially with 2methylallyl 4-methoxybenzoate (1a, $206 \mathrm{mg}, 1.00 \mathrm{mmol}, 1$ equiv), $N$-methoxy pyridinium methylsulfate (2b, $1.11 \mathrm{~g}, 5.00 \mathrm{mmol}, 5.00$ equiv), and cobalt bis(acetylacetonate) (257 mg, $1.00 \mathrm{mmol}, 1.00 \mathrm{equiv}$ ). The reaction vessel was evacuated and refilled using a balloon of argon. This process was repeated twice. Dichloromethane $(5.00 \mathrm{~mL})$, triethylsilane $(800 \mu \mathrm{L}, 5.00 \mathrm{mmol}, 5.00$ equiv), and a solution of tert-butyl hydroperoxide in nonane $(\sim 5.5 \mathrm{M}, 182 \mu \mathrm{L}, 1.00 \mathrm{mmol}, 1.00$ equiv) were then added in sequence via syringe. The reaction vessel was protected from light with aluminum foil. The reaction mixture was stirred for $16 \mathrm{~h}$ at $24{ }^{\circ} \mathrm{C}$. The product mixture was transferred to a separatory funnel that had been charged with ethyl acetate $(200 \mathrm{~mL})$. The diluted product mixture was washed with $3 \mathrm{M}$ aqueous ammonium hydroxide solution $(3 \times 50 \mathrm{~mL})$. The organic layer was isolated and the isolated organic layer was dried over sodium sulfate. The dried solution was filtered and the filtrate was concentrated. The residue obtained was purified by automated flash-column chromatography (eluting with dichloromethane initially, grading to $10 \%$ methanol-dichloromethane, linear gradient). The mixture obtained was repurified by flashcolumn chromatography (eluting with $10 \%$ ethyl acetate-10\% dichloromethane-10\% triethylaminehexanes) to afford 2-methyl-2-(pyridin-4-yl)propyl 4-methoxybenzoate (3j) as a colorless oil (189 $\mathrm{mg}$, $66 \%$ ). The mixture containing the minor regioisomer was repurified three times by automated flashcolumn chromatography (eluting with hexanes initially, grading to $33 \%$ ether-hexanes, linear gradient) to afford 2-methyl-2-(pyridin-2-yl)propyl 4-methoxybenzoate (3v) as a colorless oil (38.9 $\mathrm{mg}, 14 \%)$.

2-Methyl-2-(pyridin-2-yl)propyl 4-methoxybenzoate (3v): $\mathrm{R}_{f}=0.61$ (40\% ether-hexanes; UV) ${ }^{1} \mathrm{H}$ NMR $\left(400 \mathrm{MHz}, \mathrm{CDCl}_{3}\right) \delta 8.59\left(\mathrm{~d}, \mathrm{~J}=4.8 \mathrm{~Hz}, 1 \mathrm{H}, \mathrm{H}_{9}\right), 7.85\left(\mathrm{~d}, \mathrm{~J}=8.4 \mathrm{~Hz}, 2 \mathrm{H}, \mathrm{H}_{2}\right), 7.64\left(\mathrm{t}, \mathrm{J}=7.4 \mathrm{~Hz}, 1 \mathrm{H}, \mathrm{H}_{7}\right)$, $7.38\left(\mathrm{~d}, \mathrm{~J}=8.4 \mathrm{~Hz}, 1 \mathrm{H}, \mathrm{H}_{6}\right), 7.12\left(\mathrm{dd}, \mathrm{J}=6.4,5.2 \mathrm{~Hz}, 1 \mathrm{H}, \mathrm{H}_{8}\right), 6.86\left(\mathrm{~d}, \mathrm{~J}=8.4 \mathrm{~Hz}, 2 \mathrm{H}, \mathrm{H}_{3}\right), 4.50(\mathrm{~s}, 2 \mathrm{H}$, $\left.\mathrm{H}_{4}\right), 3.82\left(\mathrm{~s}, 3 \mathrm{H}, \mathrm{H}_{1}\right), 1.48\left(\mathrm{~s}, 6 \mathrm{H}, \mathrm{H}_{5}\right) .{ }^{13} \mathrm{C} \mathrm{NMR}\left(100 \mathrm{MHz}, \mathrm{CDCl}_{3}\right) \delta 166.1(\mathrm{C}), 165.3(\mathrm{C}), 163.2(\mathrm{C})$, $148.9(\mathrm{CH}), 136.2(\mathrm{CH}), 131.5(\mathrm{CH}), 122.7(\mathrm{C}), 121.2(\mathrm{CH}), 120.0(\mathrm{CH}), 113.5(\mathrm{CH}), 72.5\left(\mathrm{CH}_{2}\right), 55.4$ $\left(\mathrm{CH}_{3}\right), 41.2(\mathrm{C}), 25.1\left(\mathrm{CH}_{3}\right)$. IR (ATR-FTIR), $\mathrm{cm}^{-1}: 2971(\mathrm{w}), 1709$ (s), $1606(\mathrm{~s}), 1512(\mathrm{~m}), 1273(\mathrm{~m})$, 1256 (s), 1167 (s), $1102(\mathrm{w}), 1029$ (s), $770(\mathrm{~m})$. HRMS-ESI (m/z): $[\mathrm{M}+\mathrm{H}]^{+}$calcd for $\mathrm{C}_{17} \mathrm{H}_{20} \mathrm{NO}_{3}$, 286.1443; found, 286.1440 . 


\section{Large scale hydropyridylation of $1 p$ (Figure 1)}

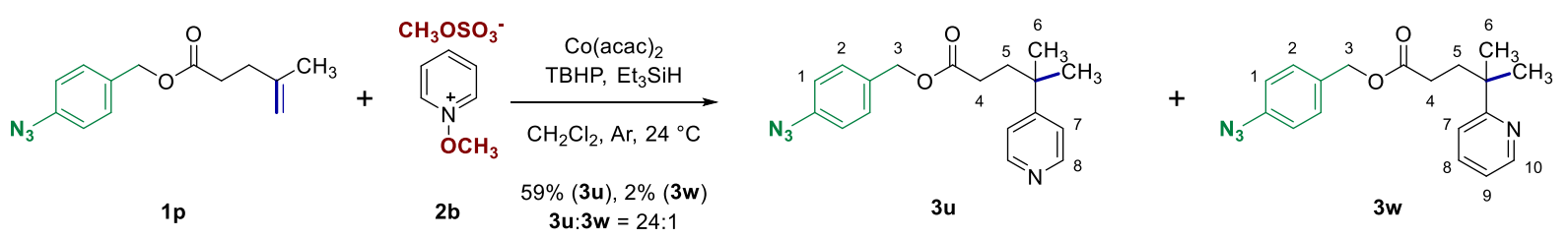

A $25-\mathrm{mL}$ round-bottomed flask fitted with a rubber septum was charged sequentially with 4azidobenzyl 4-methylpent-4-enoate (1p, $245 \mathrm{mg}, 1.00 \mathrm{mmol}, 1$ equiv), $N$-methoxy pyridinium methylsulfate (2b, $1.11 \mathrm{~g}, 5.00 \mathrm{mmol}, 5.00$ equiv), and cobalt bis(acetylacetonate) $(257 \mathrm{mg}, 1.00 \mathrm{mmol}$, 1.00 equiv). The reaction vessel was evacuated and refilled using a balloon of argon. This process was repeated twice. Dichloromethane $(5.00 \mathrm{~mL})$, triethylsilane $(800 \mu \mathrm{L}, 5.00 \mathrm{mmol}, 5.00$ equiv), and a solution of tert-butyl hydroperoxide in nonane $(\sim 5.5 \mathrm{M}, 182 \mu \mathrm{L}, 1.00 \mathrm{mmol}, 1.00$ equiv) were then added in sequence via syringe. The reaction vessel was protected from light with aluminum foil. The reaction mixture was stirred for $16 \mathrm{~h}$ at $24{ }^{\circ} \mathrm{C}$. The product mixture was transferred to a separatory funnel that had been charged with ethyl acetate $(200 \mathrm{~mL})$. The diluted product mixture was washed with $3 \mathrm{M}$ aqueous ammonium hydroxide solution $(3 \times 50 \mathrm{~mL})$. The organic layer was isolated and the isolated organic layer was dried over sodium sulfate. The dried solution was filtered and the filtrate was concentrated. The residue obtained was purified by flash-column chromatography (eluting with 10\% ethyl acetate-10\% dichloromethane-10\% triethylamine-hexanes). The mixture containing the major regioisomer was repurified by automated flash-column chromatography (eluting with $10 \%$ ethyl acetate-hexanes initially, grading to $66 \%$ ethyl acetate-hexanes, linear gradient) to afford 4-azidobenzyl 4-methyl-4-(pyridin-4yl)pentanoate (3u) as a light yellow oil (191 $\mathrm{mg}, 59 \%)$. The mixture containing the minor regioisomer was repurified twice by automated flash-column chromatography (eluting with hexanes initially, grading to $20 \%$ ether-hexanes, linear gradient) to afford 4-azidobenzyl 4-methyl-4-(pyridin-2-yl)pentanoate (3w) as a light yellow oil (8.0 mg, 2.4\%).

4-Azidobenzyl 4-methyl-4-(pyridin-4-yl)pentanoate (3u): $\mathrm{R}_{f}=0.55$ (60\% ethyl acetate-hexanes; UV) ${ }^{1} \mathrm{H}$ $\operatorname{NMR}\left(400 \mathrm{MHz}, \mathrm{CDCl}_{3}\right) \delta 8.52\left(\mathrm{br} \mathrm{s}, 2 \mathrm{H}, \mathrm{H}_{8}\right), 7.28\left(\mathrm{~d}, \mathrm{~J}=8.4 \mathrm{~Hz}, 2 \mathrm{H}, \mathrm{H}_{1}\right), 7.20\left(\mathrm{~d}, \mathrm{~J}=6.0 \mathrm{~Hz}, 2 \mathrm{H}, \mathrm{H}_{7}\right)$, $6.98\left(\mathrm{~d}, \mathrm{~J}=8.4 \mathrm{~Hz}, 2 \mathrm{H}, \mathrm{H}_{2}\right), 4.98\left(\mathrm{~s}, 2 \mathrm{H}, \mathrm{H}_{3}\right), 2.10-2.04\left(\mathrm{~m}, 2 \mathrm{H}, \mathrm{H}_{4}\right), 2.01-1.95\left(\mathrm{~m}, 2 \mathrm{H}, \mathrm{H}_{5}\right), 1.29(\mathrm{~s}, 6 \mathrm{H}$, $\left.\mathrm{H}_{6}\right) .{ }^{13} \mathrm{C}$ NMR $\left(125 \mathrm{MHz}, \mathrm{CDCl}_{3}\right) \delta 173.2(\mathrm{C}), 157.1(\mathrm{C}), 149.9(\mathrm{CH}), 140.1(\mathrm{C}), 132.5(\mathrm{C}), 130.0(\mathrm{CH})$, $121.2(\mathrm{CH}), 119.1(\mathrm{CH}), 65.7\left(\mathrm{CH}_{2}\right), 38.1\left(\mathrm{CH}_{2}\right), 37.3(\mathrm{C}), 30.0\left(\mathrm{CH}_{2}\right), 27.9\left(\mathrm{CH}_{3}\right)$. IR (ATR-FTIR), $\mathrm{cm}^{-1}$ : 2966 (w), 1109 (s), 1731 (s), 1597 (m), 1508 (s), 1410 (m), 1284 (s), 1159 (s), 1129 (m), 995 (w), 964 (w), 821 (s). HRMS-ESI (m/z): [M + H] calcd for $\mathrm{C}_{18} \mathrm{H}_{21} \mathrm{~N}_{4} \mathrm{O}_{3}, 325.1665$; found, 325.1670 .

4-Azidobenzyl 4-methyl-4-(pyridin-2-yl)pentanoate (3w): $\mathrm{R}_{f}=0.68$ (33\% ether-hexanes; UV) ${ }^{1} \mathrm{H}$ NMR $\left(400 \mathrm{MHz}, \mathrm{CDCl}_{3}\right) \delta 8.58\left(\right.$ br s, $\left.1 \mathrm{H}, \mathrm{H}_{10}\right), 7.61\left(\mathrm{t}, \mathrm{J}=6.4 \mathrm{~Hz}, 1 \mathrm{H}, \mathrm{H}_{8}\right), 7.32-7.27\left(\mathrm{~m}, 3 \mathrm{H}, 2 \times \mathrm{H}_{2}, 1 \times \mathrm{H}_{7}\right)$, 7.10-7.08 (m, 1H, $\left.\mathrm{H}_{9}\right), 7.00\left(\mathrm{~d} . \mathrm{J}=8.4 \mathrm{~Hz}, 2 \mathrm{H}, \mathrm{H}_{1}\right), 5.01\left(\mathrm{~s}, 2 \mathrm{H}, \mathrm{H}_{3}\right), 2.16-2.09\left(\mathrm{~m}, 4 \mathrm{H}, 2 \times \mathrm{H}_{4}, 2 \times \mathrm{H}_{5}\right)$, $1.36\left(\mathrm{~s}, 6 \mathrm{H}, \mathrm{H}_{6}\right) .{ }^{13} \mathrm{C} \mathrm{NMR}\left(150 \mathrm{MHz}, \mathrm{CDCl}_{3}\right) \delta 173.7(\mathrm{C}), 166.9(\mathrm{C}), 148.8(\mathrm{CH}), 139.9(\mathrm{C}), 136.2(\mathrm{CH})$, $132.7(\mathrm{C}), 129.9(\mathrm{CH}), 120.8(\mathrm{CH}), 119.9(\mathrm{CH}), 119.1(\mathrm{CH}), 65.5\left(\mathrm{CH}_{2}\right), 39.9(\mathrm{C}), 37.8\left(\mathrm{CH}_{2}\right), 30.2\left(\mathrm{CH}_{2}\right)$, $27.7\left(\mathrm{CH}_{3}\right)$. IR (ATR-FTIR), $\mathrm{cm}^{-1}: 2958(\mathrm{~m}), 2925$ (m), 2101 (s), 1735 (s), $1588(\mathrm{w}), 1509$ (m), 1285 (s), $1156(\mathrm{~s}), 1116(\mathrm{~m})$. HRMS-ESI (m/z): $[\mathrm{M}+\mathrm{H}]^{+}$calcd for $\mathrm{C}_{18} \mathrm{H}_{21} \mathrm{~N}_{4} \mathrm{O}_{3}, 325.1665$; found, 325.1650. 
4-(1-((4-methoxybenzoyl)oxy)-2-methylpropan-2-yl)cyclohexa-2,5-dien-1-yl tricarbonyl manganese(I) (6, Scheme 1)

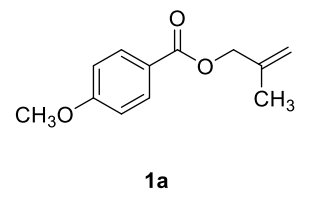

$1 \mathrm{a}$

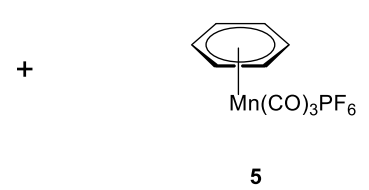

5

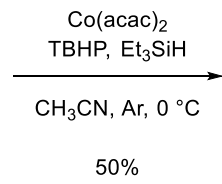

$50 \%$

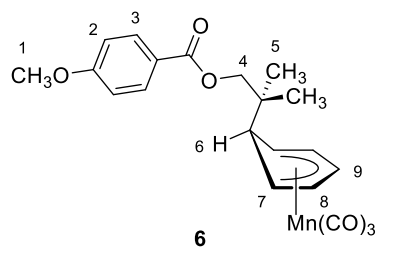

A 10-mL round-bottomed flask fitted with a rubber septum was charged sequentially with 2methylallyl 4-methoxybenzoate (1a, $51.5 \mathrm{mg}, 250 \mu \mathrm{mol}, 1$ equiv), ( $\eta^{6}$-benzene) manganese tricarbonyl hexafluorophosphate $(\mathbf{5}, 90.5 \mathrm{mg}, 250 \mu \mathrm{mol}, 1.00$ equiv), and cobalt bis(acetylacetonate) $(64.3 \mathrm{mg}, 250$ $\mu$ mol, 1.00 equiv). The reaction vessel was evacuated and refilled using a balloon of argon. This process was repeated twice. Acetonitrile $(1.25 \mathrm{~mL})$ was added to the reaction vessel via syringe and the reaction vessel was cooled to $0{ }^{\circ} \mathrm{C}$. Triethylsilane $(200 \mu \mathrm{L}, 1.25 \mathrm{mmol}, 5.00$ equiv) and a solution of tert-butyl hydroperoxide in nonane $(\sim 5.5 \mathrm{M}, 45.5 \mu \mathrm{L}, 250 \mu \mathrm{mol}, 1.00$ equiv) were added sequentially to the reaction vessel via syringe. The reaction vessel was protected from light with aluminum foil. The reaction mixture was stirred for $12 \mathrm{~h}$ at $0{ }^{\circ} \mathrm{C}$. The product mixture was concentrated to dryness and the residue obtained was purified by automated flash-column chromatography (eluting with hexanes initially, grading to $33 \%$ ethyl acetate-hexanes, linear gradient) to afford 4-(1-((4-methoxybenzoyl)oxy)-2-methylpropan-2-yl)cyclohexa2,5-dien-1-yl tricarbonyl manganese(I) (6) as a pale yellow oil (53.6 mg, 50\%).

4-(1-((4-Methoxybenzoyl)oxy)-2-methylpropan-2-yl)cyclohexa-2,5-dien-1-yl tricarbonyl manganese(I) (6): $\mathrm{R}_{f}=0.29$ (33\% ether-hexanes; UV). ${ }^{1} \mathrm{H}$ NMR $\left(400 \mathrm{MHz}, \mathrm{CDCl}_{3}\right) \delta 7.97\left(\mathrm{~d}, \mathrm{~J}=8.4 \mathrm{~Hz}, 2 \mathrm{H}, \mathrm{H}_{2}\right), 6.93(\mathrm{~d}, \mathrm{~J}$ $\left.=8.4 \mathrm{~Hz}, 2 \mathrm{H}, \mathrm{H}_{3}\right), 5.68\left(\mathrm{t}, \mathrm{J}=4.6 \mathrm{~Hz}, 1 \mathrm{H}, \mathrm{H}_{6}\right), 4.92\left(\mathrm{t}, \mathrm{J}=6.0 \mathrm{~Hz}, 2 \mathrm{H}, \mathrm{H}_{7}\right), 3.87\left(\mathrm{~s}, 3 \mathrm{H}, \mathrm{H}_{1}\right), 3.82(\mathrm{~s}, 2 \mathrm{H}$, $\left.\mathrm{H}_{4}\right), 3.21\left(\mathrm{t}, \mathrm{J}=6.0 \mathrm{~Hz}, 2 \mathrm{H}, \mathrm{H}_{8}\right), 2.80\left(\mathrm{t}, \mathrm{J}=5.4 \mathrm{~Hz}, 1 \mathrm{H}, \mathrm{H}_{9}\right), 0.69\left(\mathrm{~s}, 6 \mathrm{H}, \mathrm{H}_{5}\right) .{ }^{13} \mathrm{C} \mathrm{NMR}\left(100 \mathrm{MHz}, \mathrm{CDCl}_{3}\right)$ $\delta 222.8(\mathrm{C}), 166.2(\mathrm{C}), 163.4(\mathrm{C}), 131.5(\mathrm{CH}), 122.6(\mathrm{C}), 113.7(\mathrm{CH}), 97.8(\mathrm{CH}), 78.8(\mathrm{CH}), 69.4\left(\mathrm{CH}_{2}\right)$, $56.2\left(\mathrm{CH}_{3}\right), 55.5(\mathrm{CH}), 42.5(\mathrm{CH}), 41.4(\mathrm{C}), 20.7\left(\mathrm{CH}_{3}\right)$. IR (ATR-FTIR), $\mathrm{cm}^{-1}: 2964(\mathrm{w}), 2961(\mathrm{w}), 2008$ (s), $1907(\mathrm{~s}), 1708(\mathrm{~m}), 1606(\mathrm{~m}), 1253(\mathrm{~s}), 1166(\mathrm{~m}), 1101(\mathrm{~m}), 1029(\mathrm{~m}), 658(\mathrm{~m}), 636(\mathrm{~s}), 613(\mathrm{~s})$. HRMS-ESI (m/z): $[\mathrm{M}+\mathrm{H}]^{+}$calcd for $\mathrm{C}_{21} \mathrm{H}_{22} \mathrm{MnO}_{6}, 425.0797$; found, 425.0772 . 


\section{2-Methyl-2-phenylpropyl 4-methoxybenzoate (7, Scheme 1)}
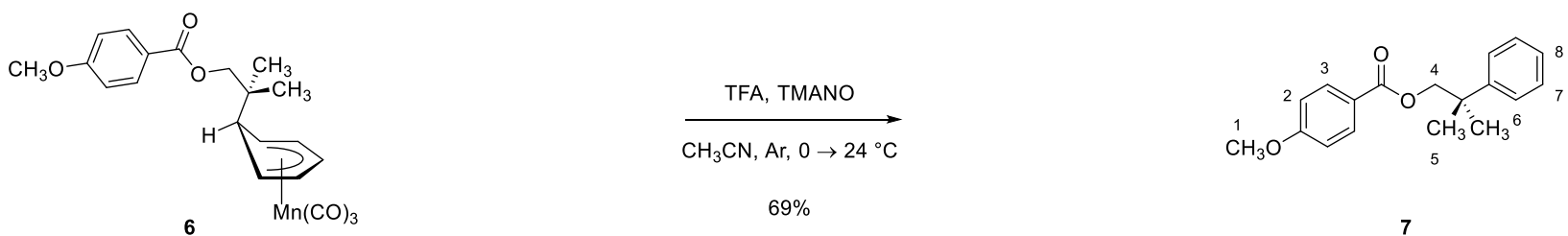

A $10-\mathrm{mL}$ round-bottomed flask fitted with a rubber septum was charged with 4-(1-((4methoxybenzoyl)oxy)-2-methylpropan-2-yl)cyclohexa-2,5-dien-1-yl tricarbonyl manganese(I) (6, $53.2 \mathrm{mg}$, $125 \mu \mathrm{mol}, 1$ equiv). The reaction vessel was evacuated and refilled using a balloon of argon. This process was repeated twice. Acetonitrile $(1.0 \mathrm{~mL})$ was added to the reaction vessel via syringe and the resulting solution was cooled to $0{ }^{\circ} \mathrm{C}$. Trimethylamine $N$-oxide $(93.9 \mathrm{mg}, 1.25 \mathrm{mmol}, 10.0$ equiv) was added to the reaction vessel in one portion and the reaction vessel was purged with a balloon of argon for $30 \mathrm{~s}$. Freshly distilled trifluoroacetic acid $(95.7 \mu \mathrm{L}, 1.25 \mathrm{mmol}, 10.0$ equiv) was added dropwise to the reaction mixture via syringe. The reaction vessel was protected from light with aluminum foil. The reaction mixture was stirred for $12 \mathrm{~h}$ at $0{ }^{\circ} \mathrm{C}$. A second portion of trimethylamine $N$-oxide ( $93.9 \mathrm{mg}, 1.25 \mathrm{mmol}, 10.0$ equiv) was then added to the reaction vessel in one portion and the reaction vessel was purged with a balloon of argon for $30 \mathrm{~s}$. A second portion of freshly distilled trifluoroacetic acid $(95.7 \mu \mathrm{L}, 1.25 \mathrm{mmol}, 10.0$ equiv) was then added dropwise to the reaction mixture via syringe. The reaction mixture was stirred for $12 \mathrm{~h}$ at $0{ }^{\circ} \mathrm{C}$ then the cooling bath was removed. The reaction mixture was allowed to warm to $24{ }^{\circ} \mathrm{C}$. The warmed reaction mixture was stirred for $12 \mathrm{~h}$ at $24{ }^{\circ} \mathrm{C}$. The product mixture was concentrated to dryness and the residue obtained was purified by automated flash-column chromatography (eluting with hexanes initially, grading to $33 \%$ ether-hexanes, linear gradient) to afford 2-methyl-2-phenylpropyl 4-methoxybenzoate (7) as an off-white solid (24.4 mg, 69\%).

2-Methyl-2-phenylpropyl 4-methoxybenzoate (7): $\mathrm{R}_{f}=0.61$ (33\% ether-hexanes; UV) ${ }^{1} \mathrm{H}$ NMR (400 MHz, $\left.\mathrm{CDCl}_{3}\right) \delta 7.95\left(\mathrm{~d}, \mathrm{~J}=6.4 \mathrm{~Hz}, 2 \mathrm{H}, \mathrm{H}_{2}\right), 7.47\left(\mathrm{~d}, 2 \mathrm{H}, \mathrm{J}=7.2 \mathrm{~Hz}, 2 \mathrm{H}, \mathrm{H}_{7}\right), 7.36\left(\mathrm{t}, \mathrm{J}=7.6 \mathrm{~Hz}, 2 \mathrm{H}, \mathrm{H}_{6}\right), 7.24(\mathrm{t}$, $\left.\mathrm{J}=7.8 \mathrm{~Hz}, 1 \mathrm{H}, \mathrm{H}_{8}\right), 6.80\left(\mathrm{~d}, \mathrm{~J}=6.4,2 \mathrm{H}, \mathrm{H}_{3}\right), 4.37\left(\mathrm{~s}, 2 \mathrm{H}, \mathrm{H}_{4}\right), 3.82\left(\mathrm{~s}, 3 \mathrm{H}, \mathrm{H}_{1}\right), 1.47\left(\mathrm{~s}, 6 \mathrm{H}, \mathrm{H}_{5}\right) .{ }^{13} \mathrm{C} \mathrm{NMR}$ $\left(100 \mathrm{MHz}, \mathrm{CDCl}_{3}\right) \delta 166.2(\mathrm{C}), 163.3(\mathrm{C}), 146.4(\mathrm{C}), 131.5(\mathrm{CH}), 128.3(\mathrm{CH}), 126.2(\mathrm{CH}), 126.0(\mathrm{CH})$, $122.7(\mathrm{C}), 113.6(\mathrm{CH}), 73.2\left(\mathrm{CH}_{2}\right), 55.4\left(\mathrm{CH}_{3}\right), 38.5(\mathrm{C}), 26.0\left(\mathrm{CH}_{3}\right)$. IR (ATR-FTIR), $\mathrm{cm}^{-1}: 2969$ (w), $1708(\mathrm{~m}), 1605(\mathrm{~m}), 1250(\mathrm{~s}), 1165(\mathrm{~s}), 1098(\mathrm{~s}), 763(\mathrm{~s}), 696(\mathrm{~s})$. HRMS-ESI (m/z): [M + H] $]^{+}$calcd for $\mathrm{C}_{18} \mathrm{H}_{21} \mathrm{O}_{3}, 285.1491$; found, 285.1498 . 
Catalog of Nuclear Magnetic Resonance Spectra, Infrared Spectra, and LC/MS Traces.

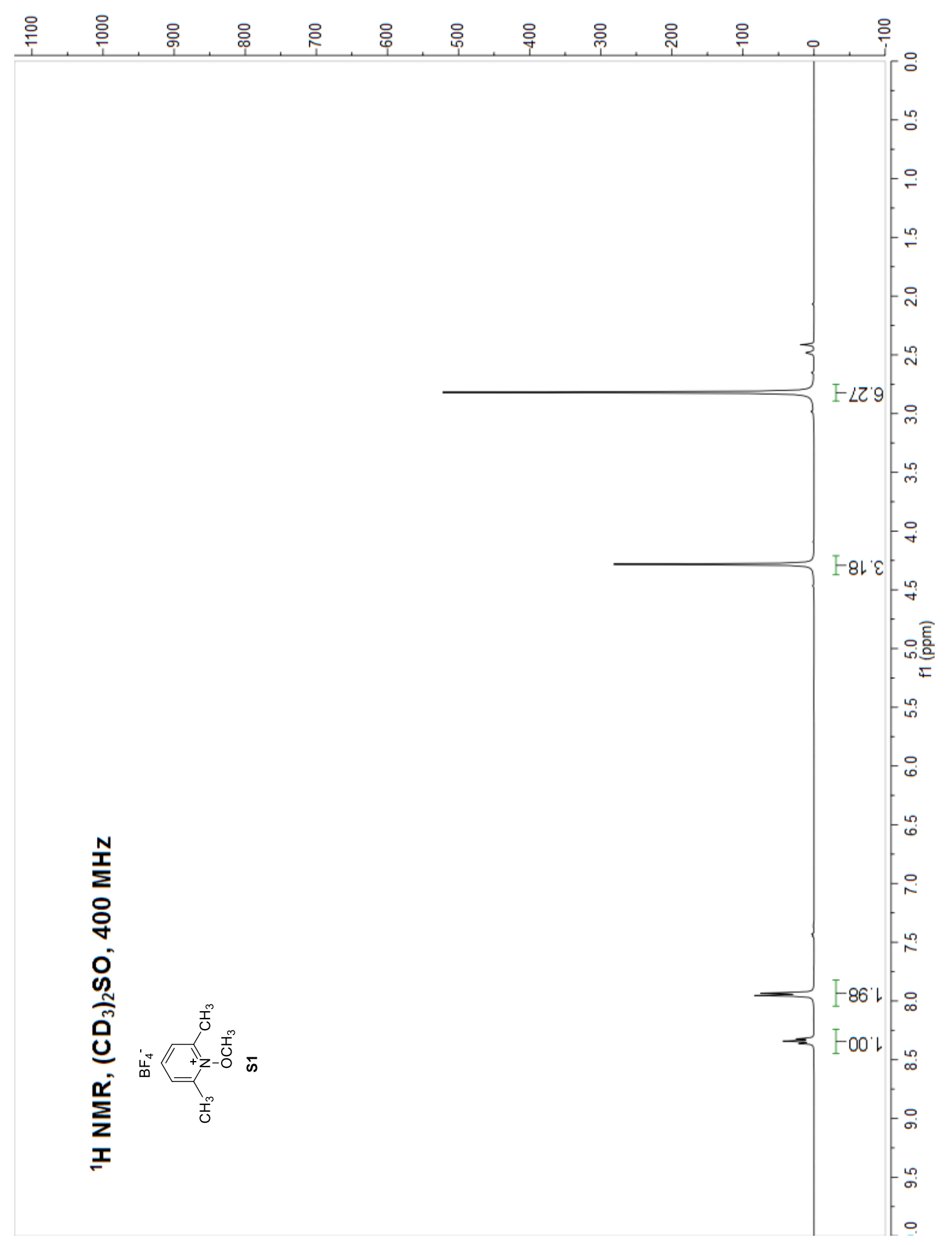




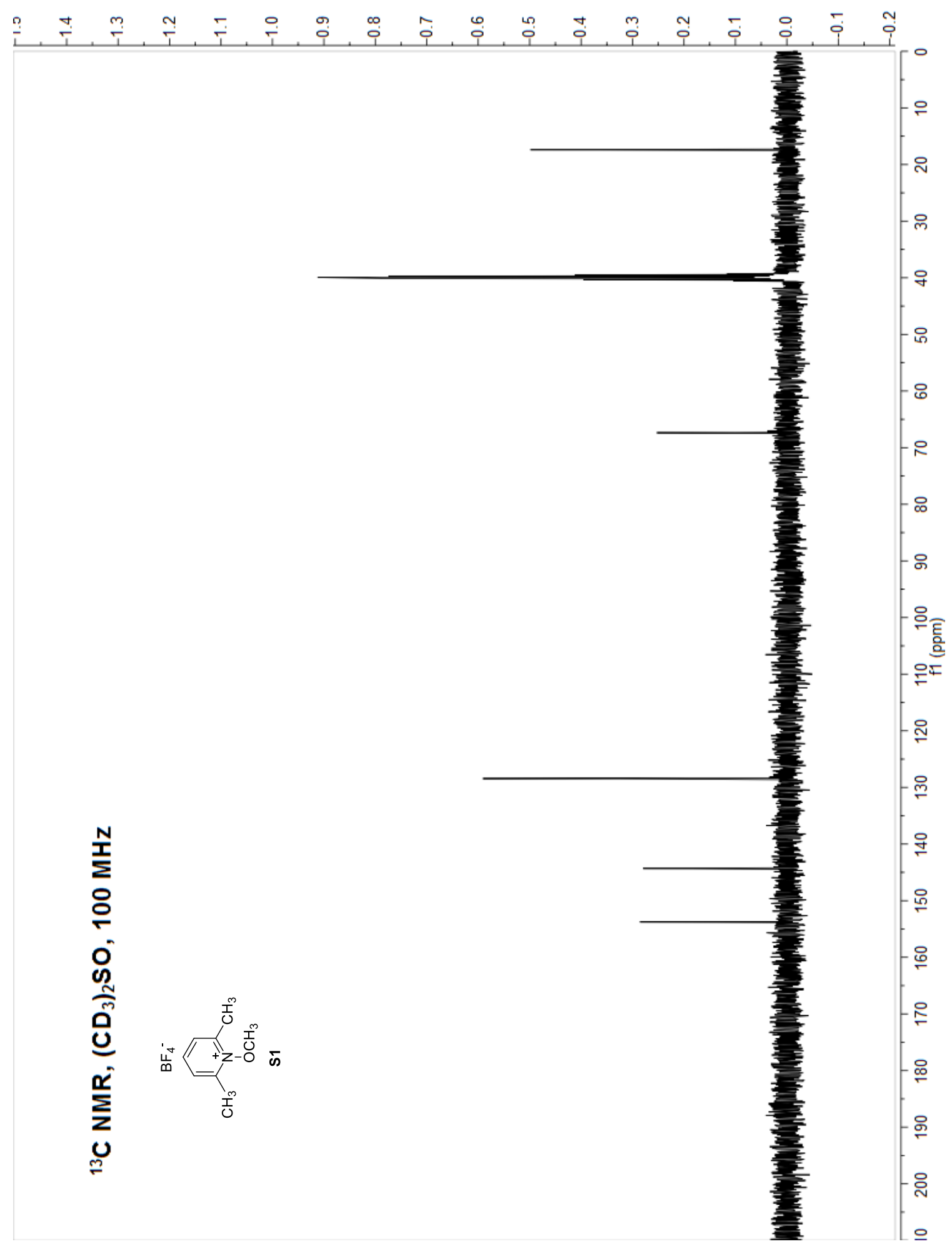




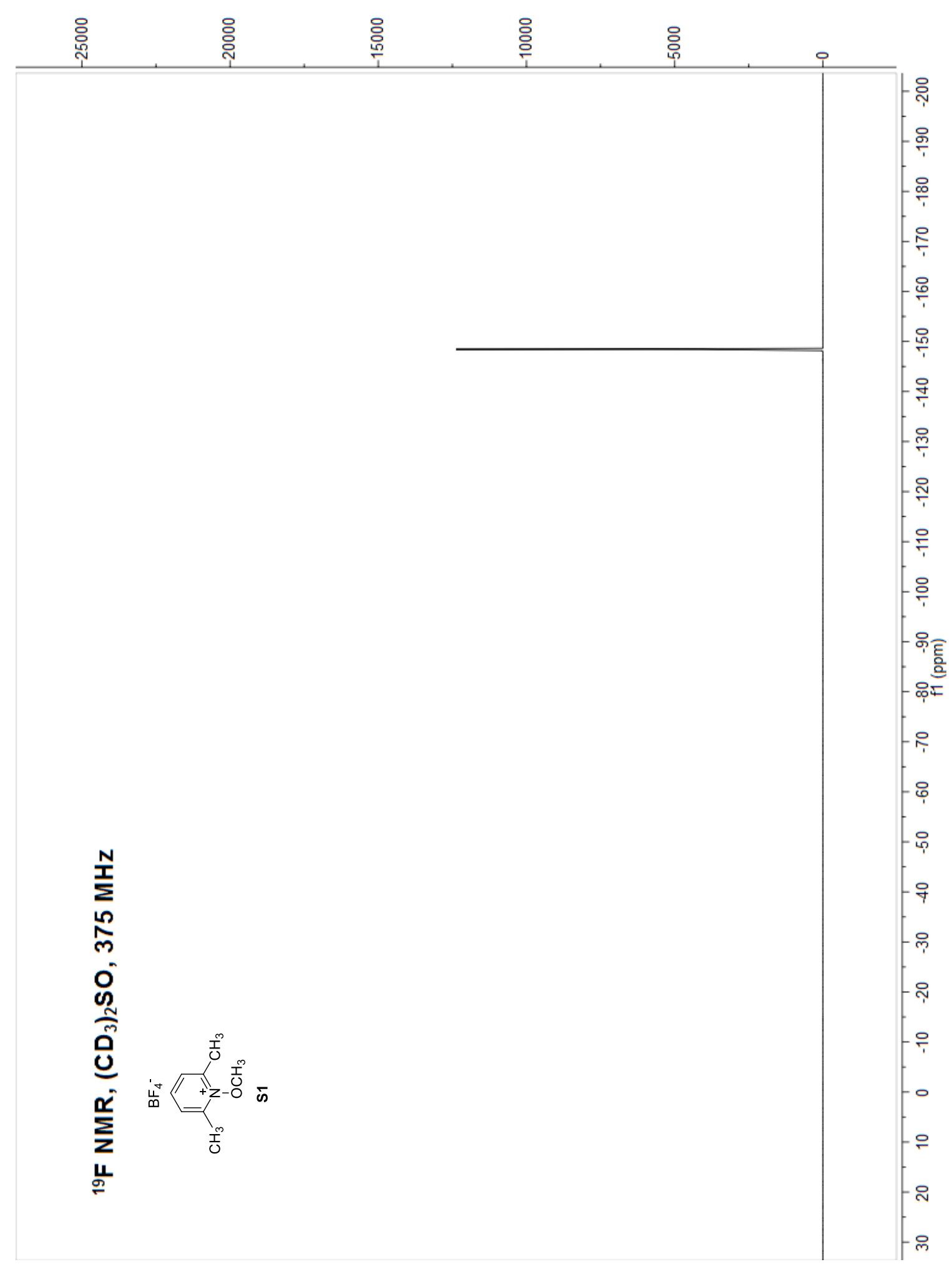




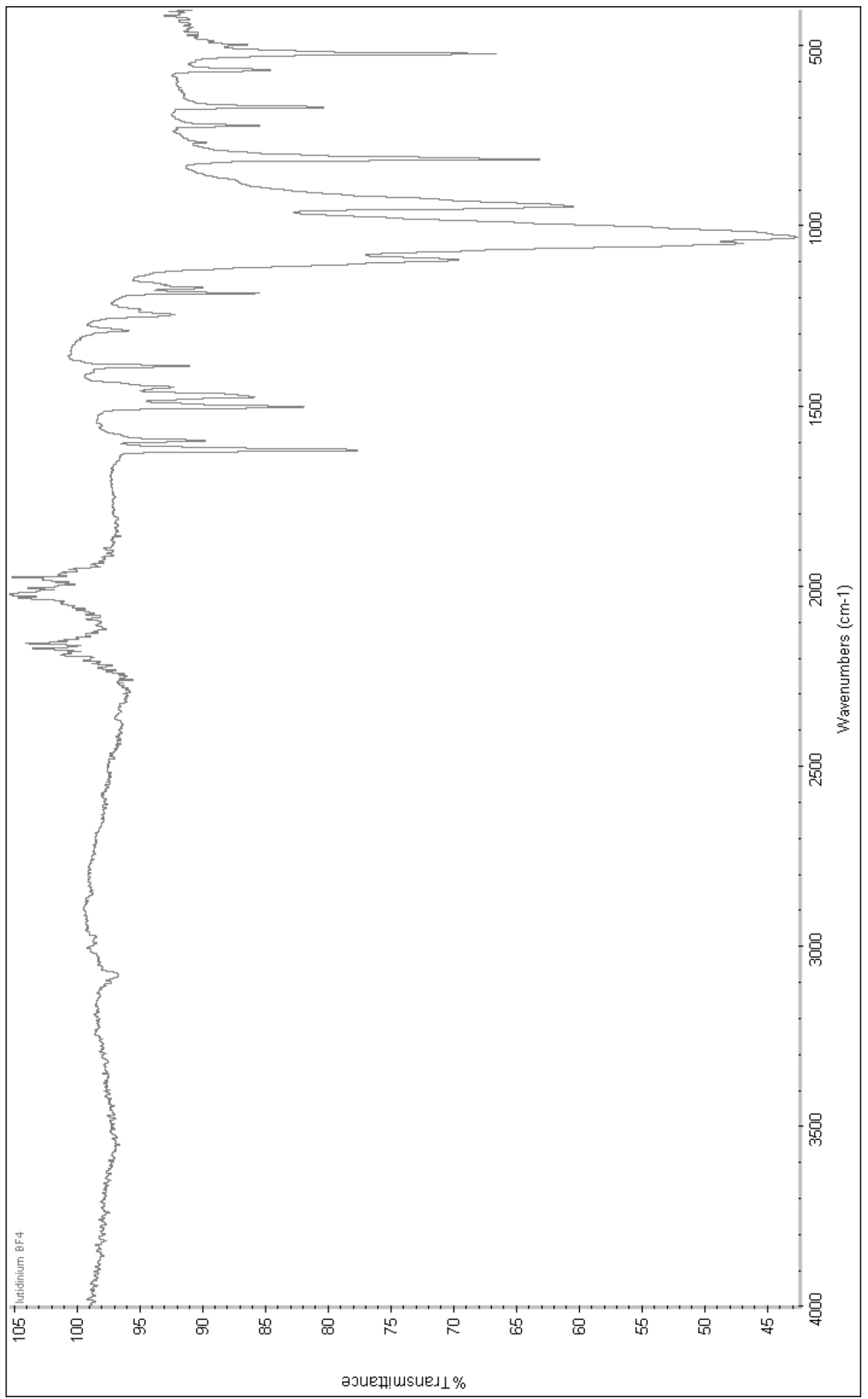

Ma and Herzon "Intermolecular hydropyridylation of unactivated alkenes" J. Am. Chem. Soc. 


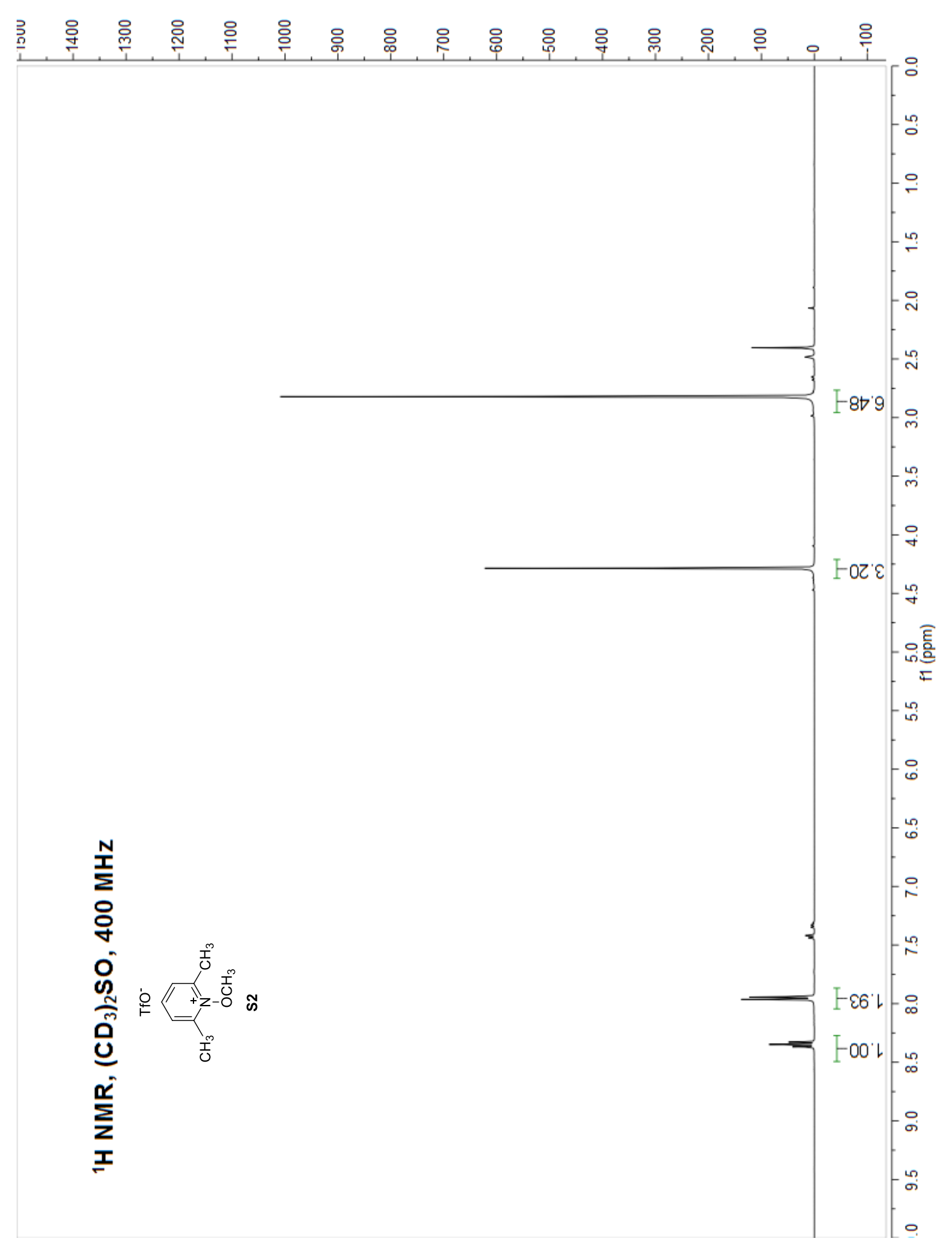




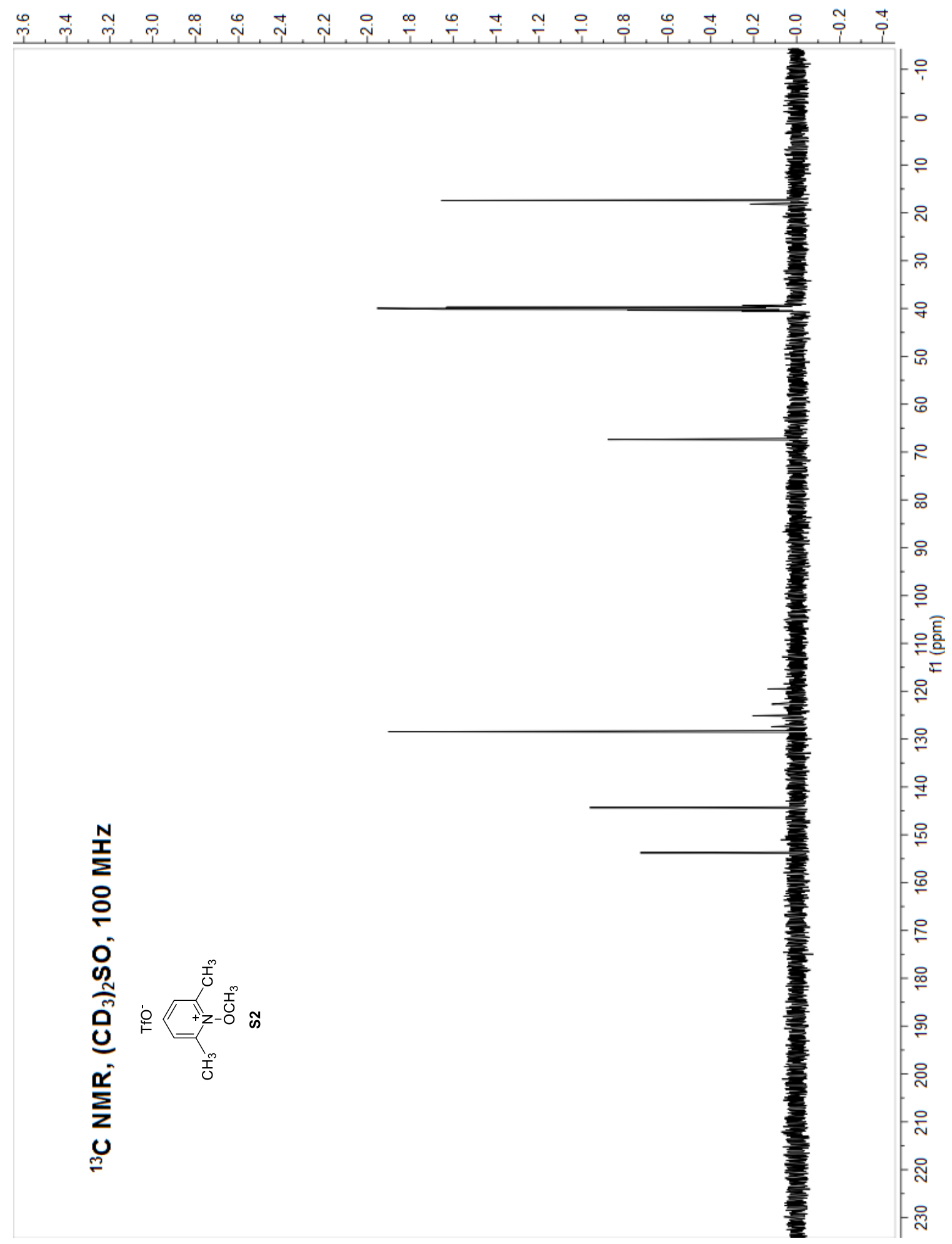




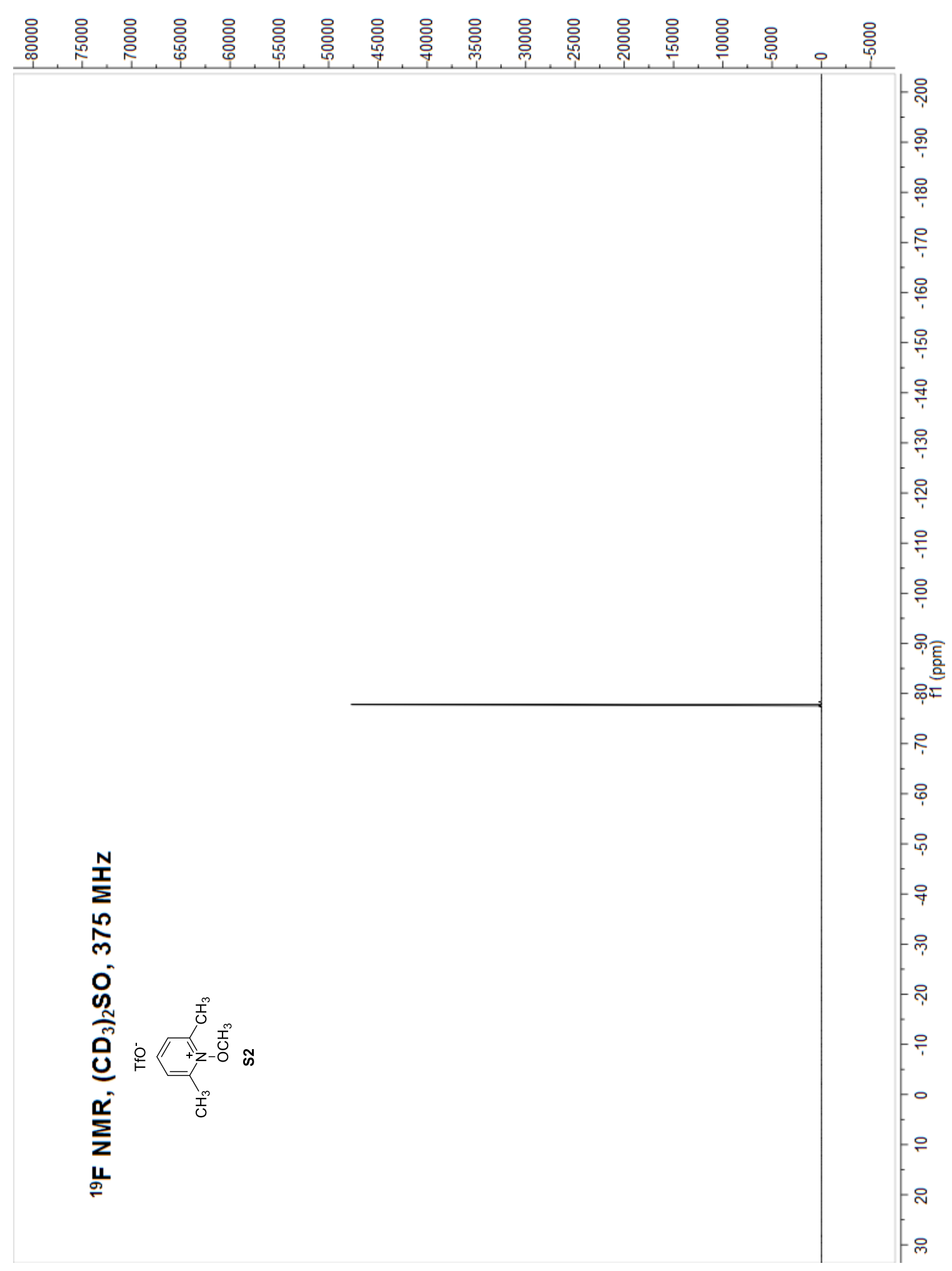




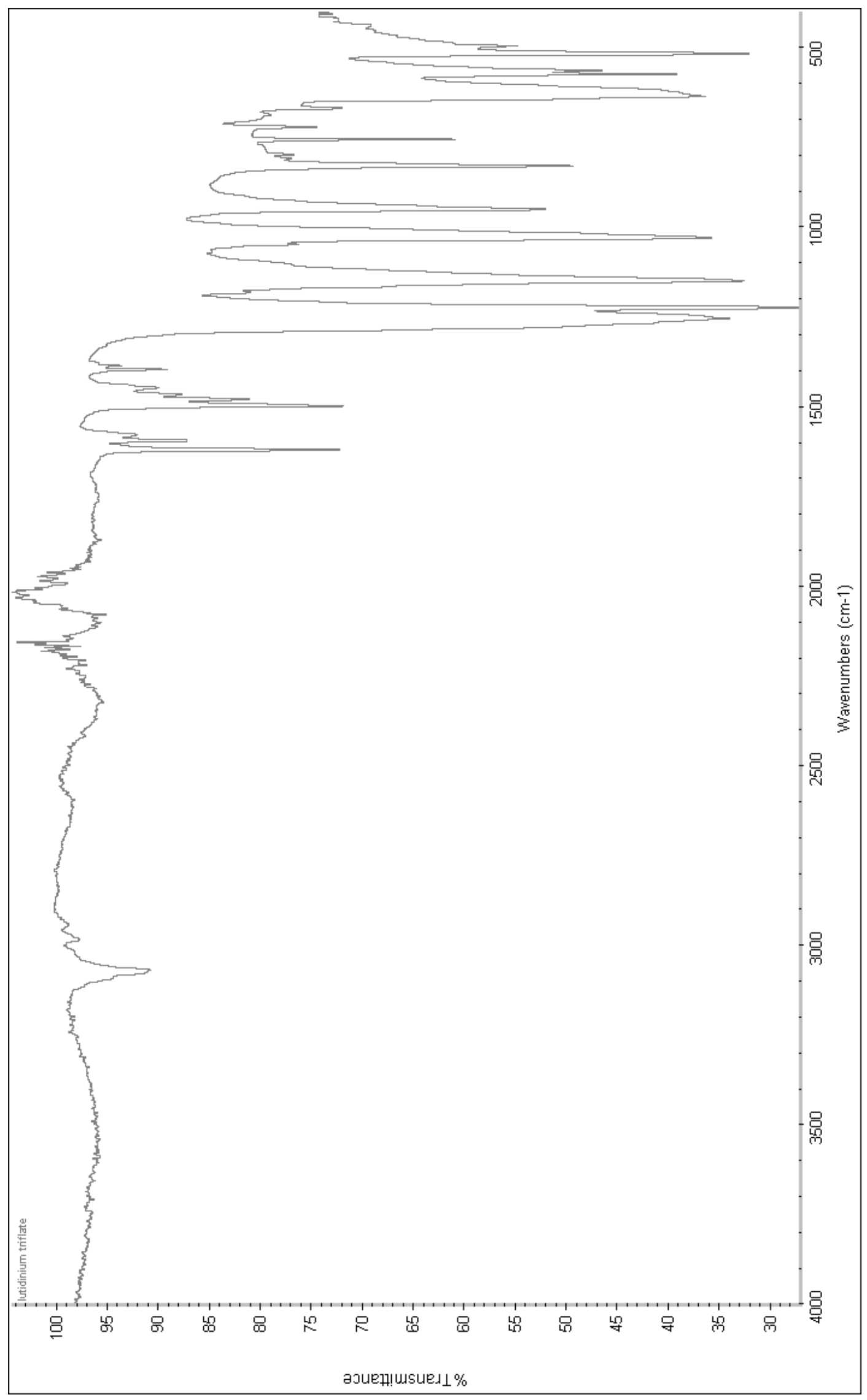




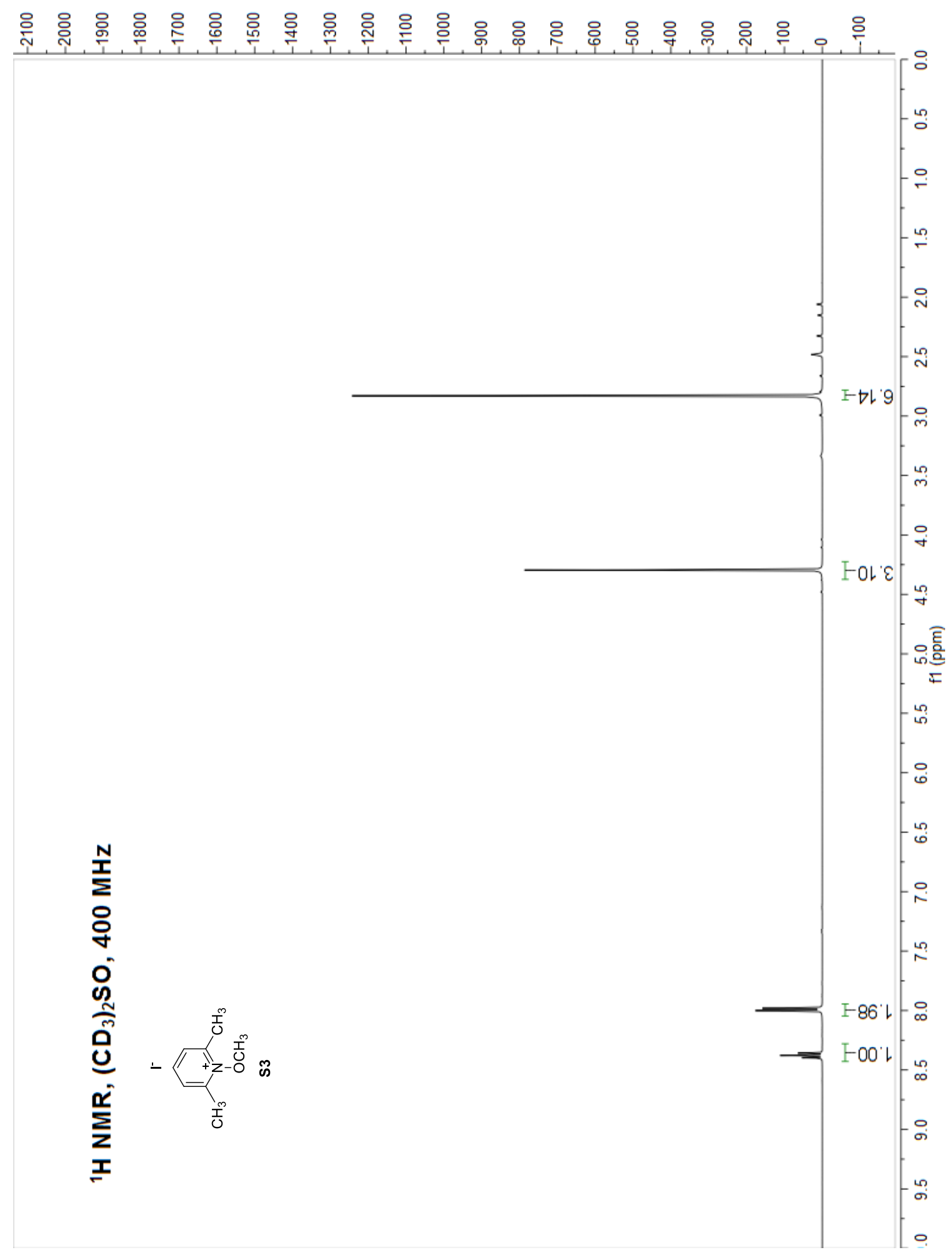




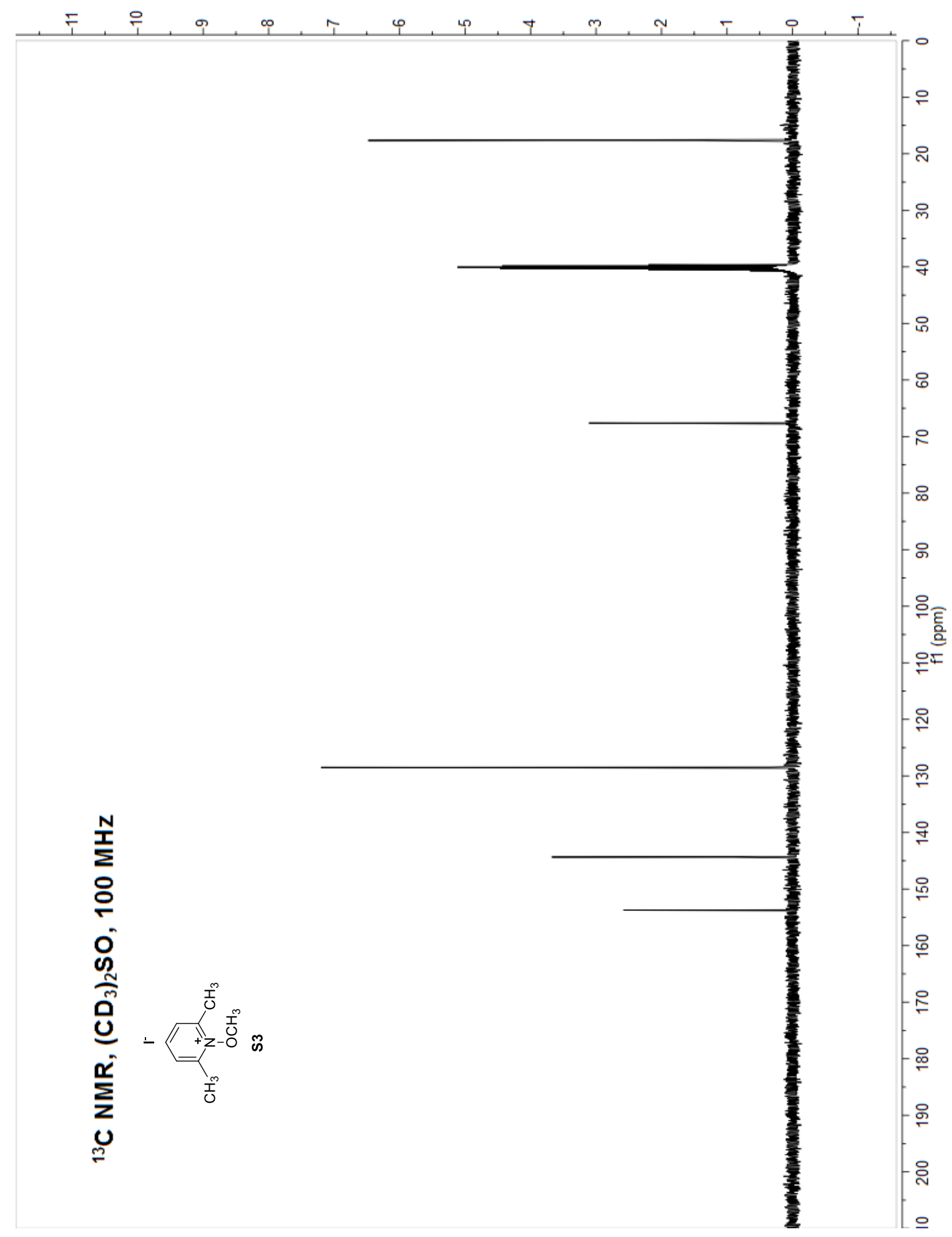




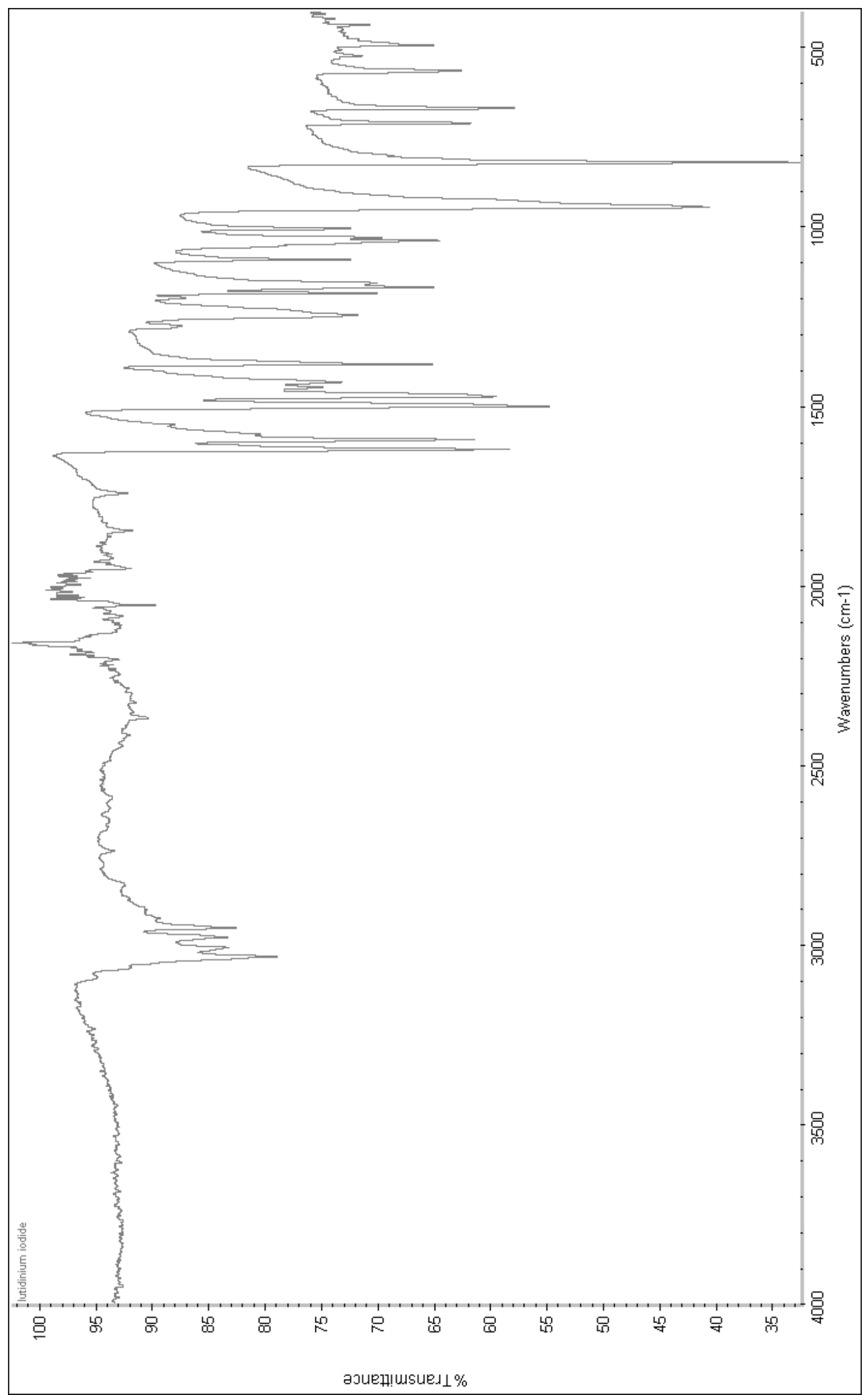

Ma and Herzon "Intermolecular hydropyridylation of unactivated alkenes" J. Am. Chem. Soc. 


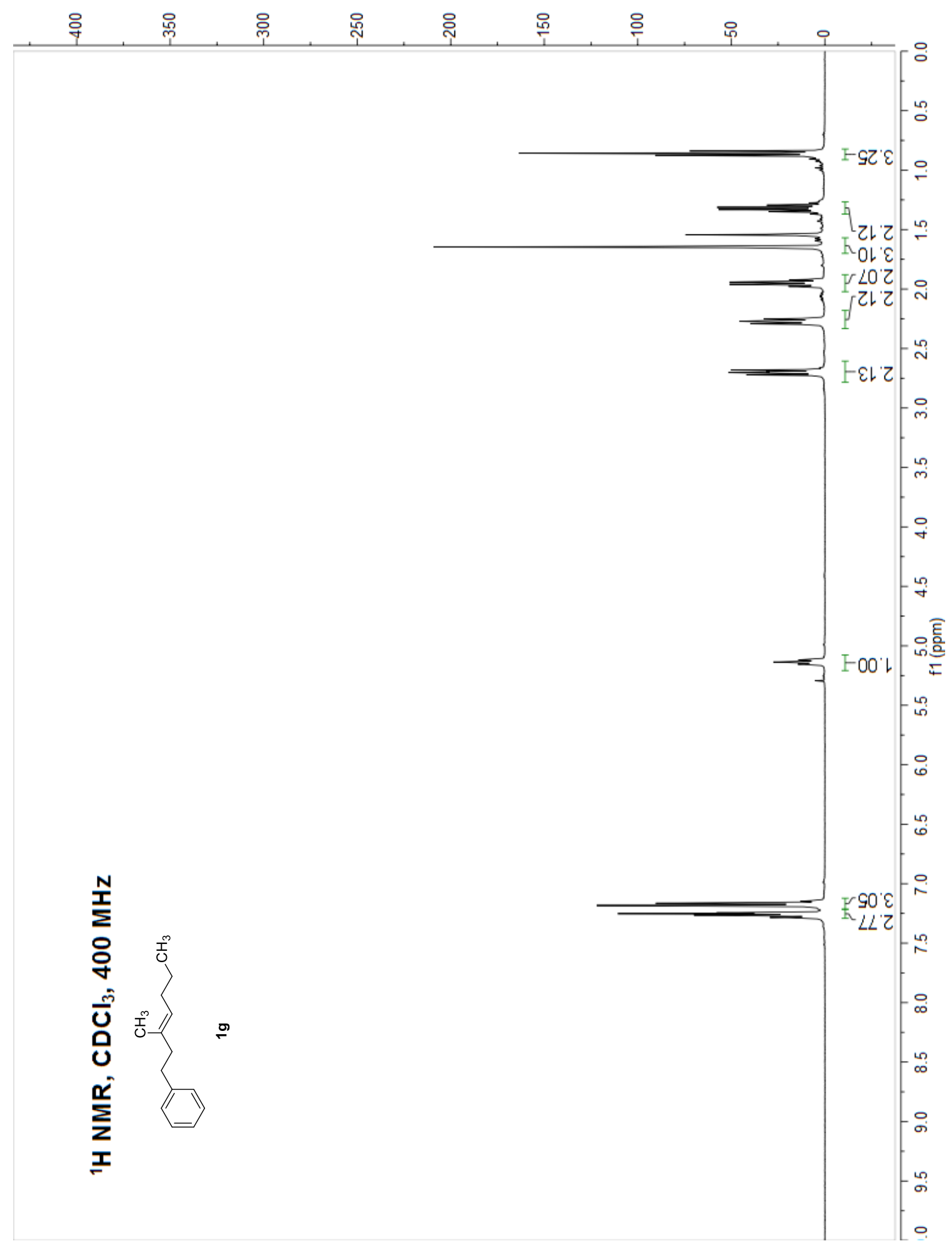




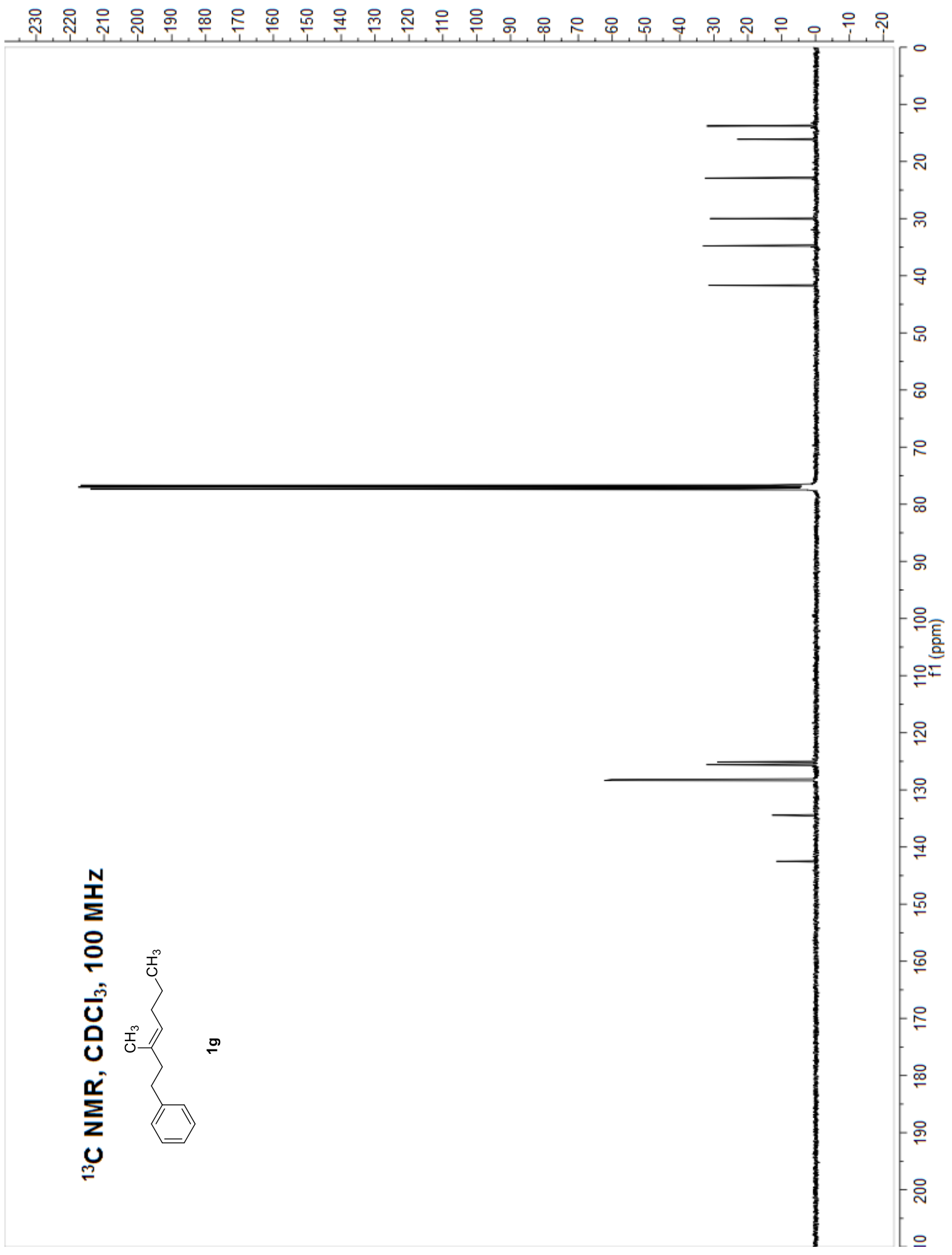




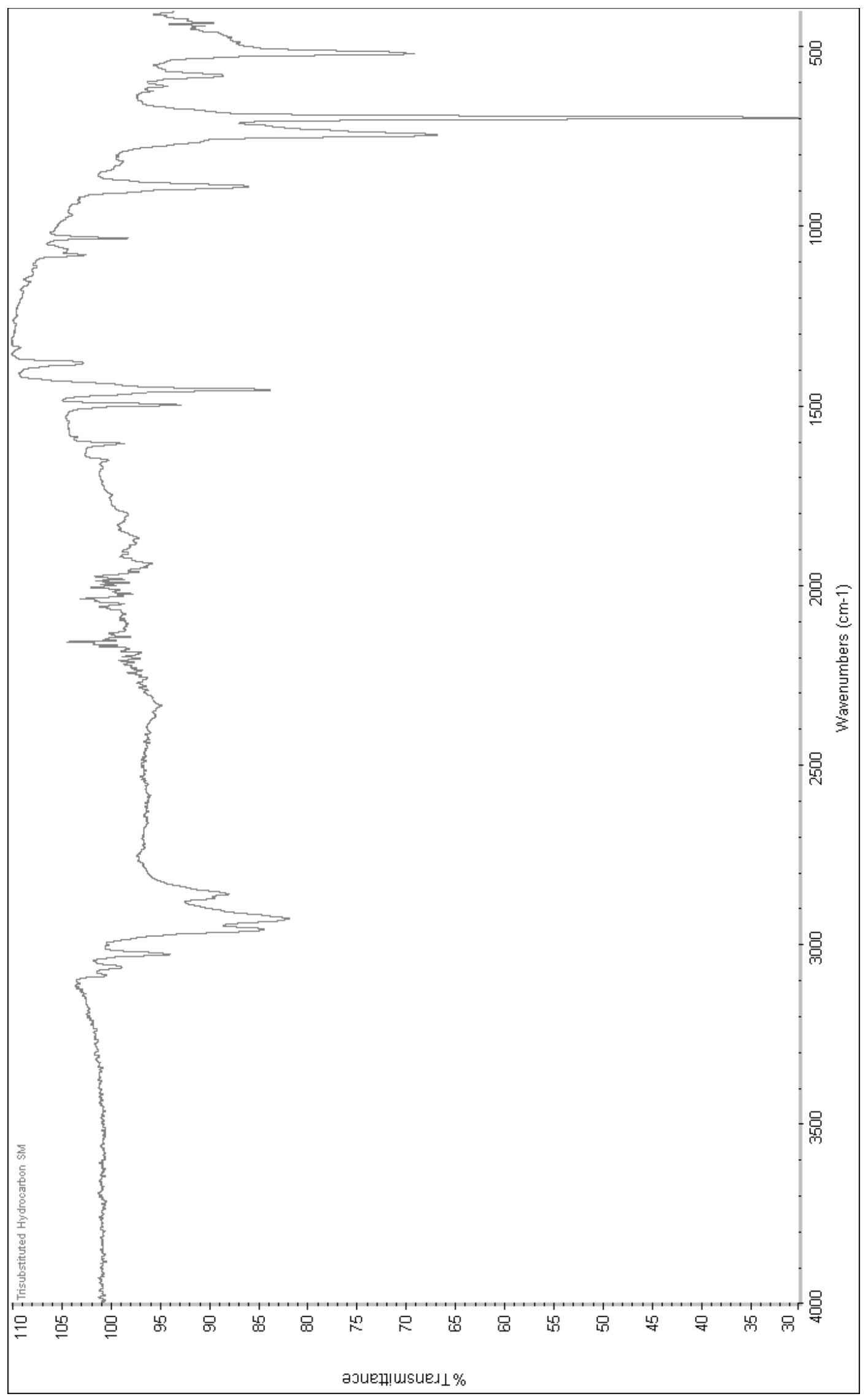




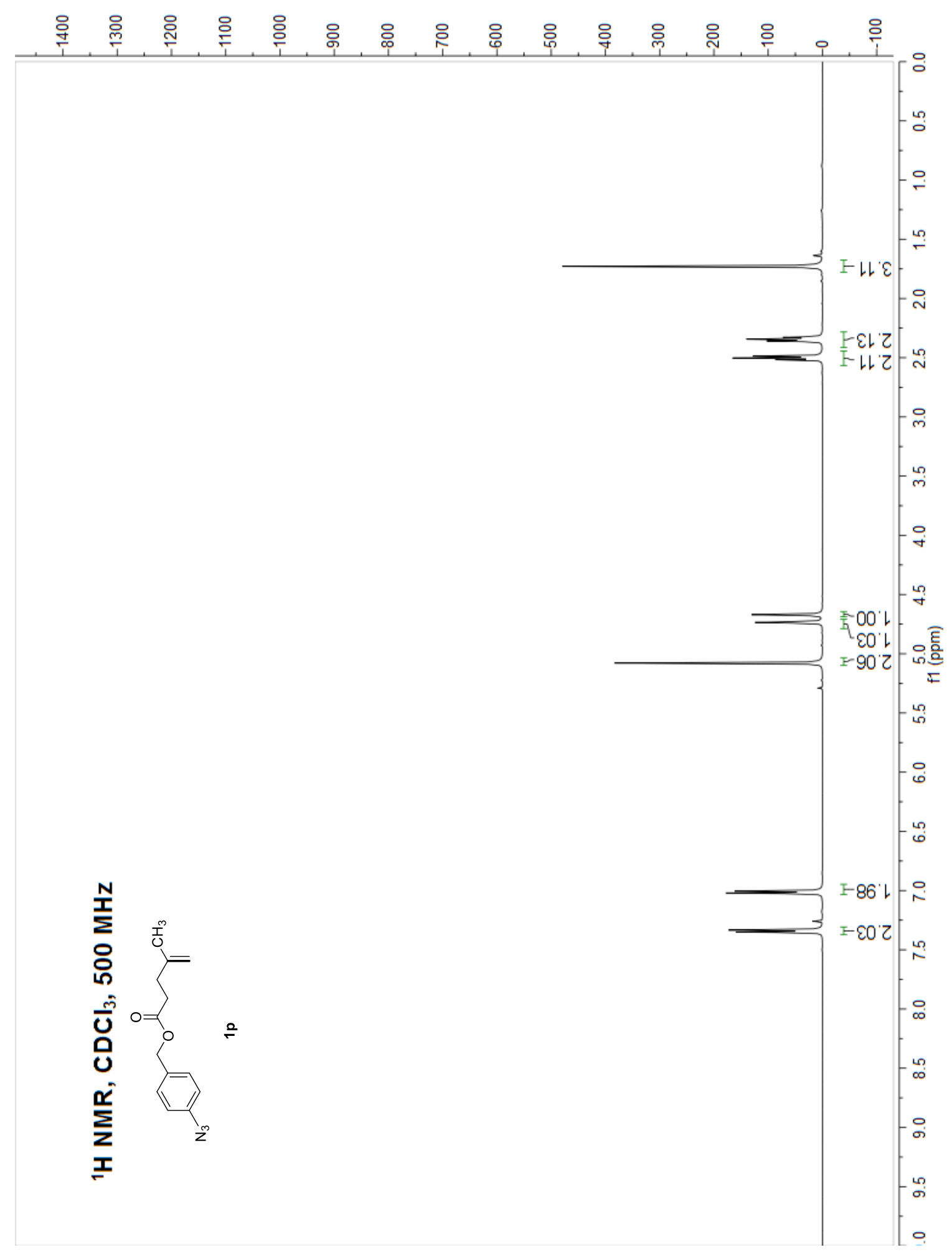




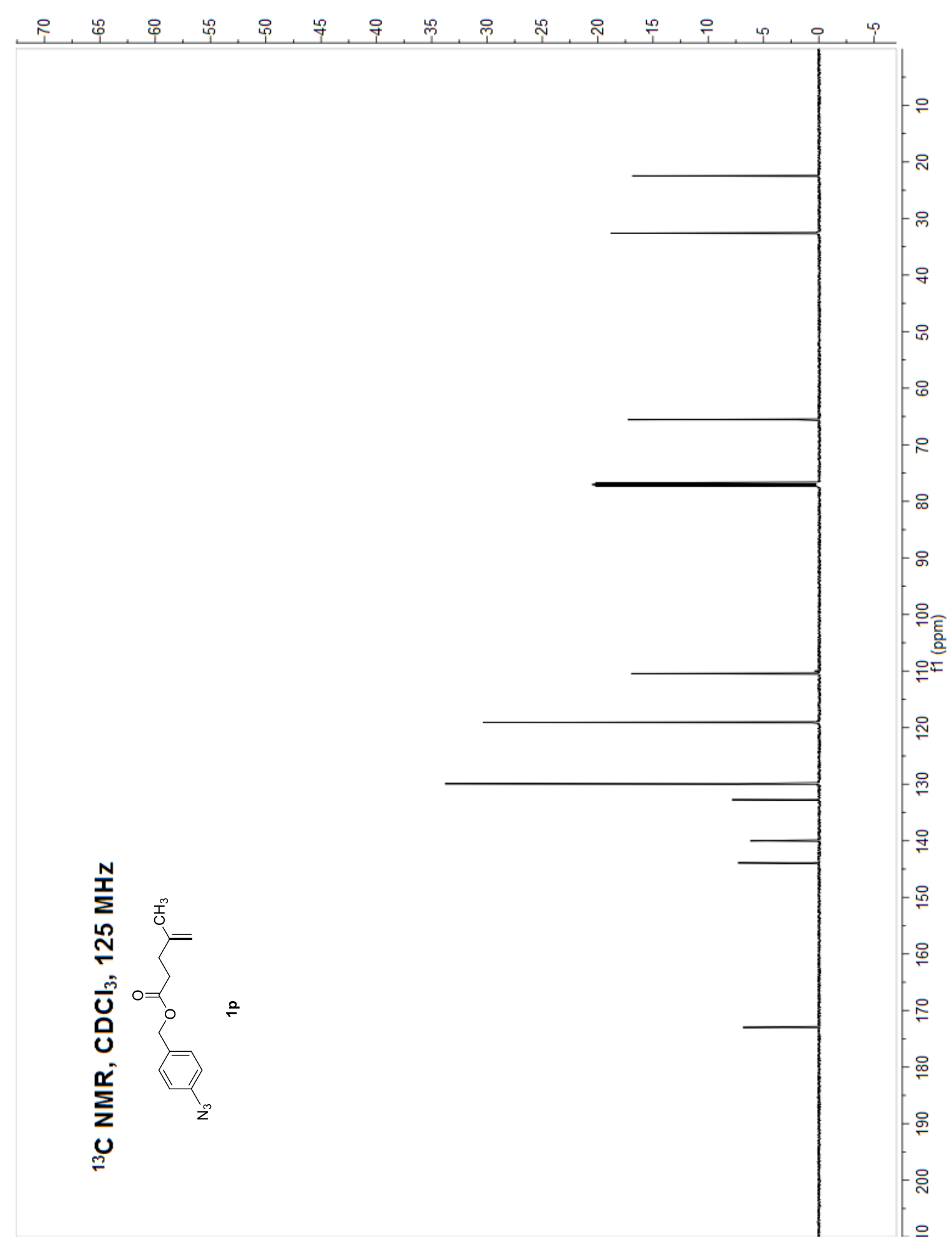




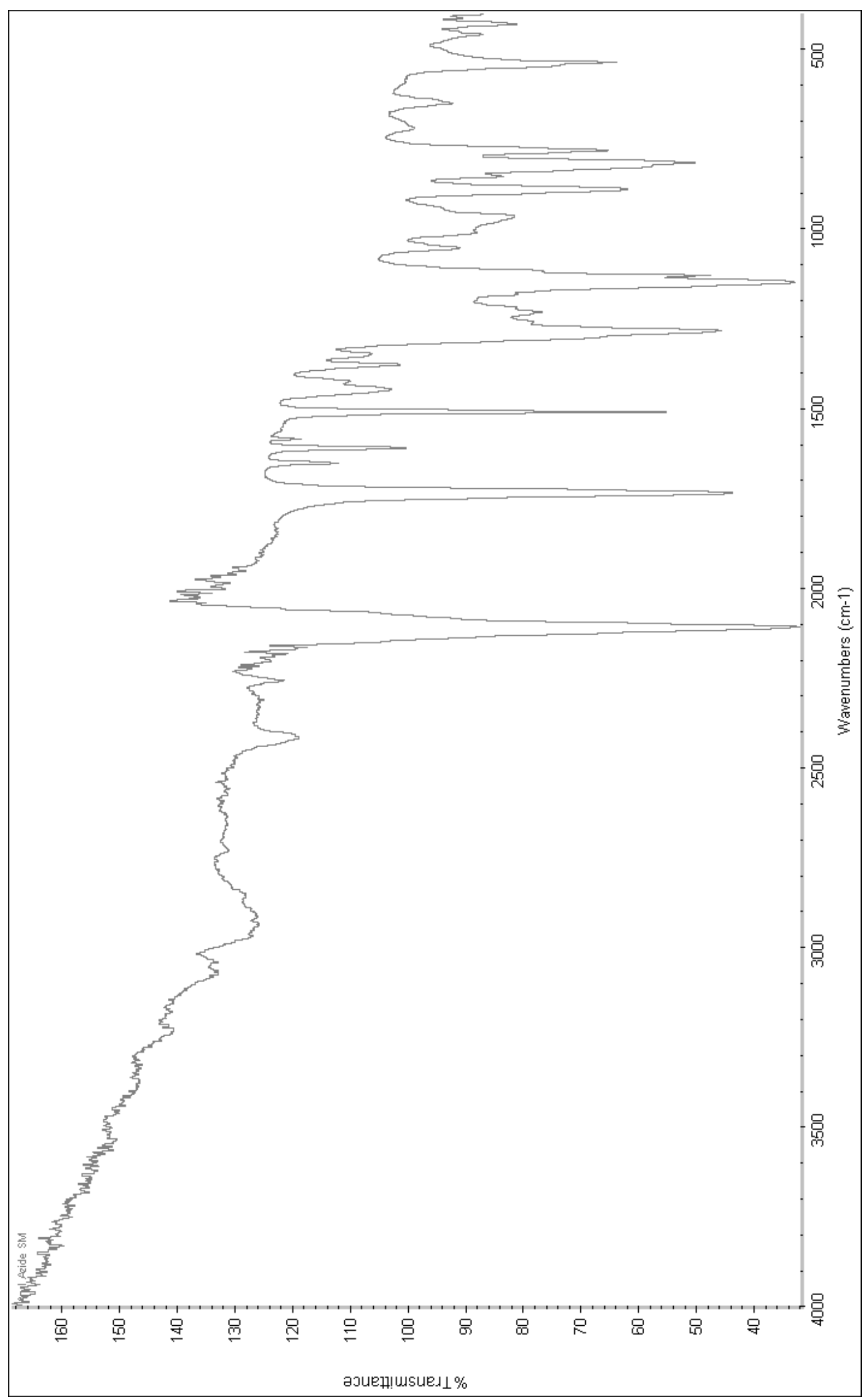

Ma and Herzon "Intermolecular hydropyridylation of unactivated alkenes" J. Am. Chem. Soc. 


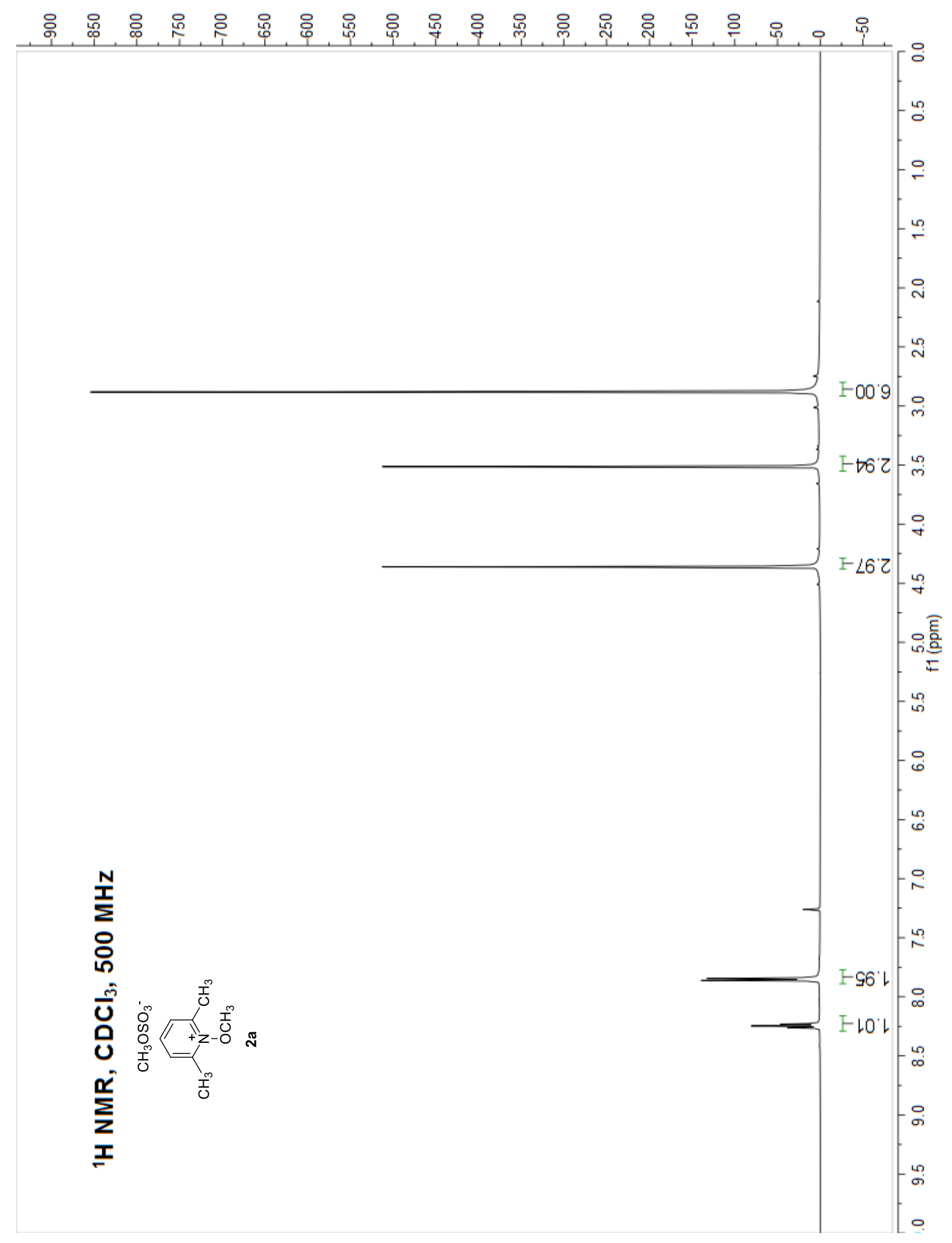




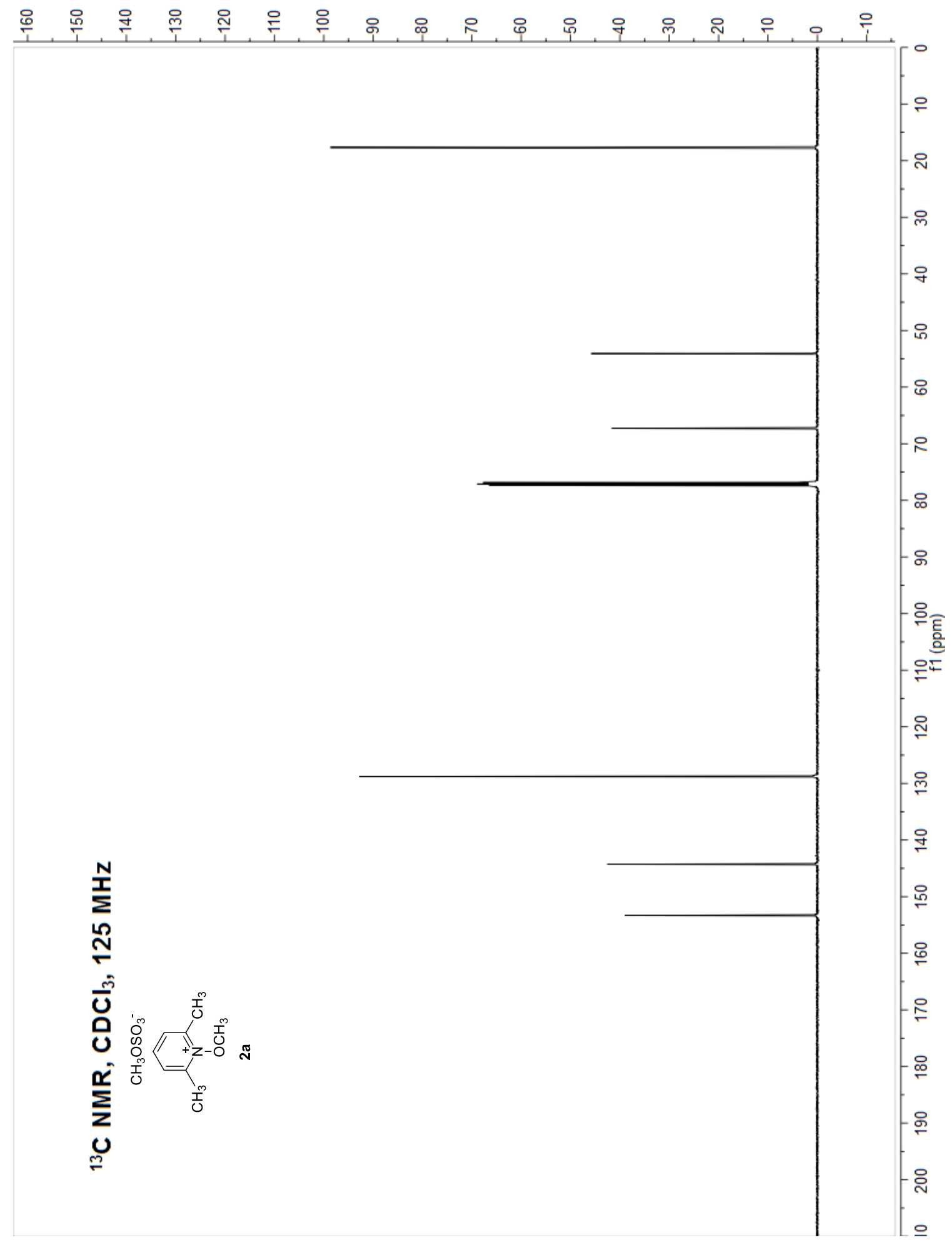




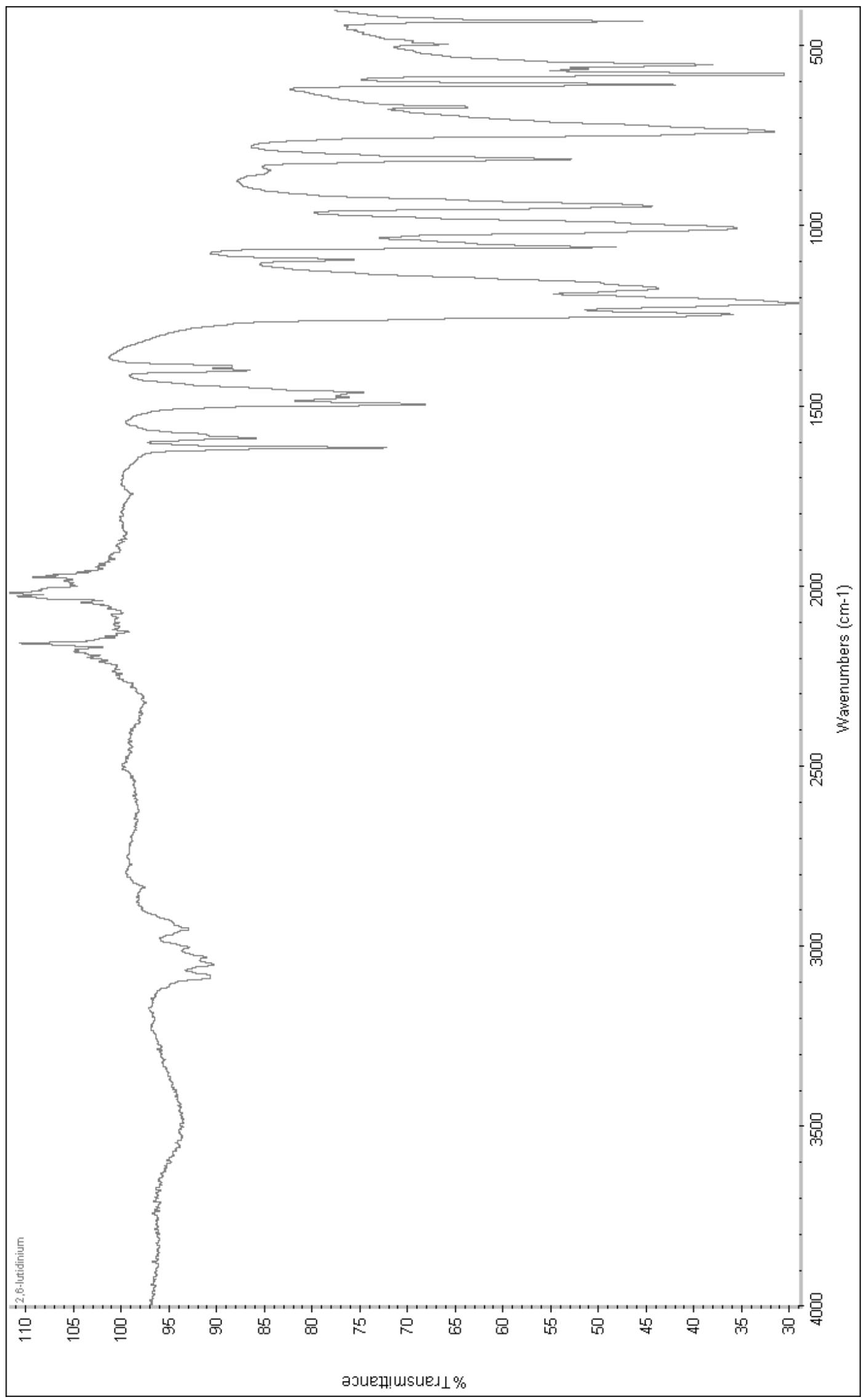

Ma and Herzon "Intermolecular hydropyridylation of unactivated alkenes" J. Am. Chem. Soc. 


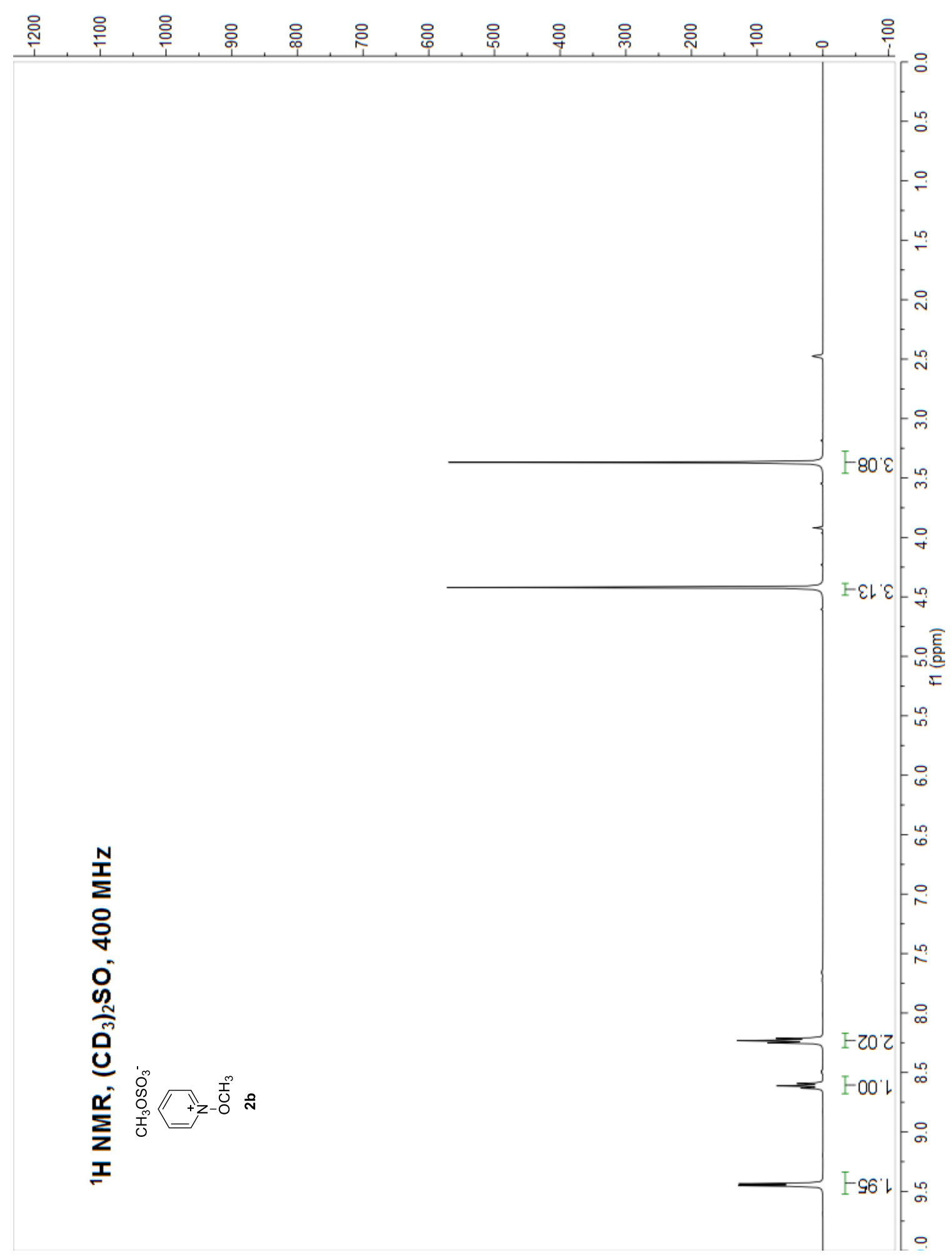




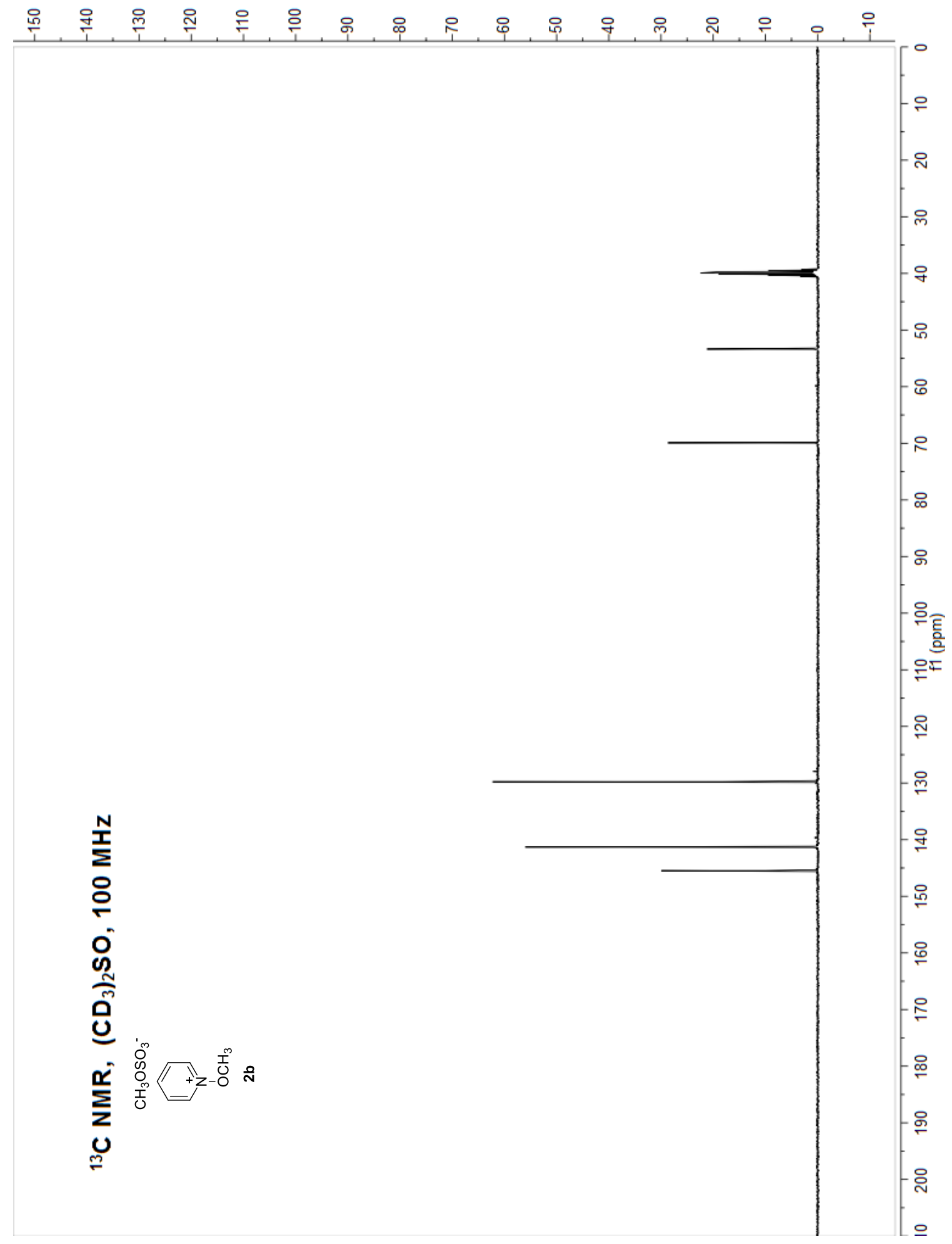




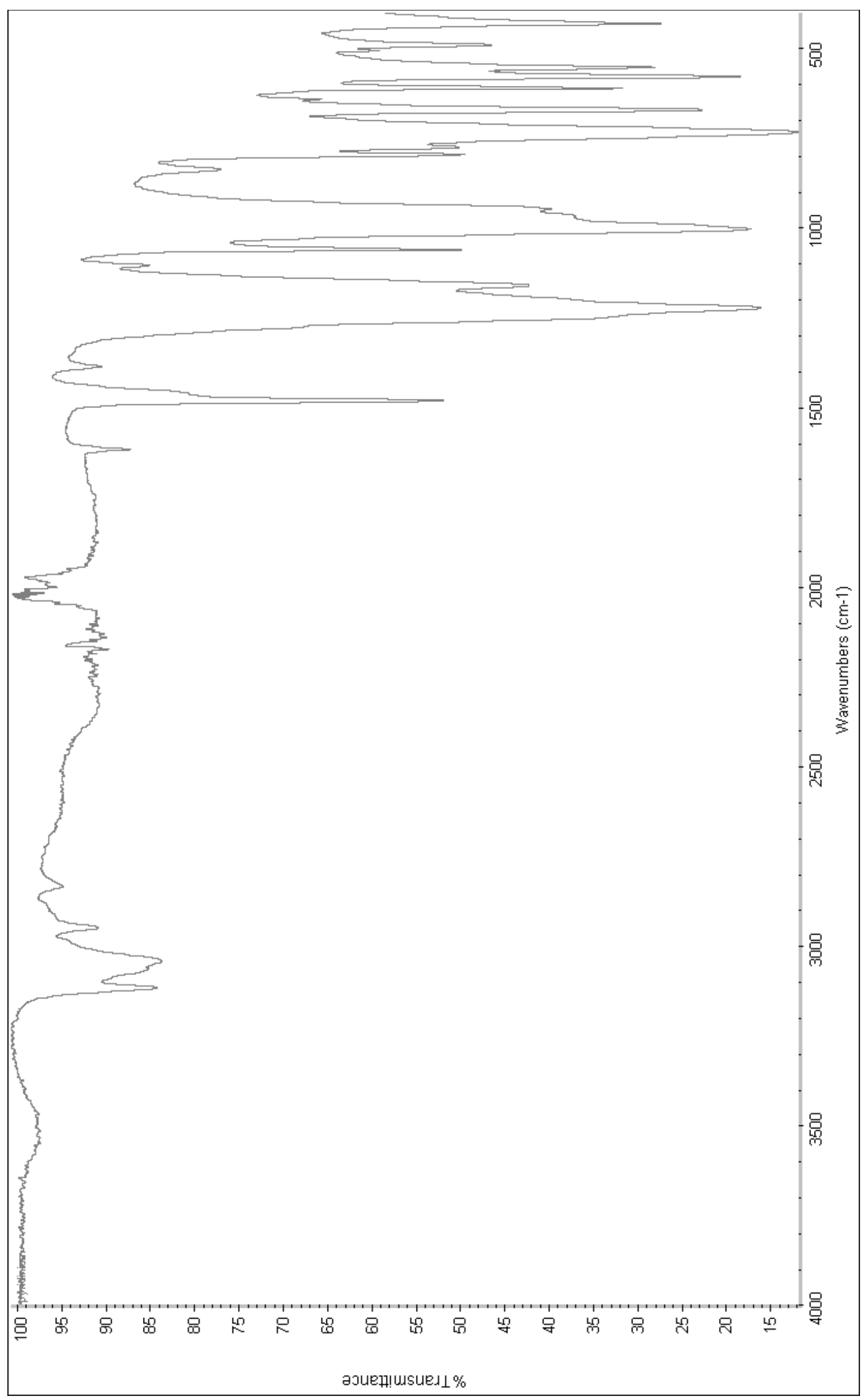




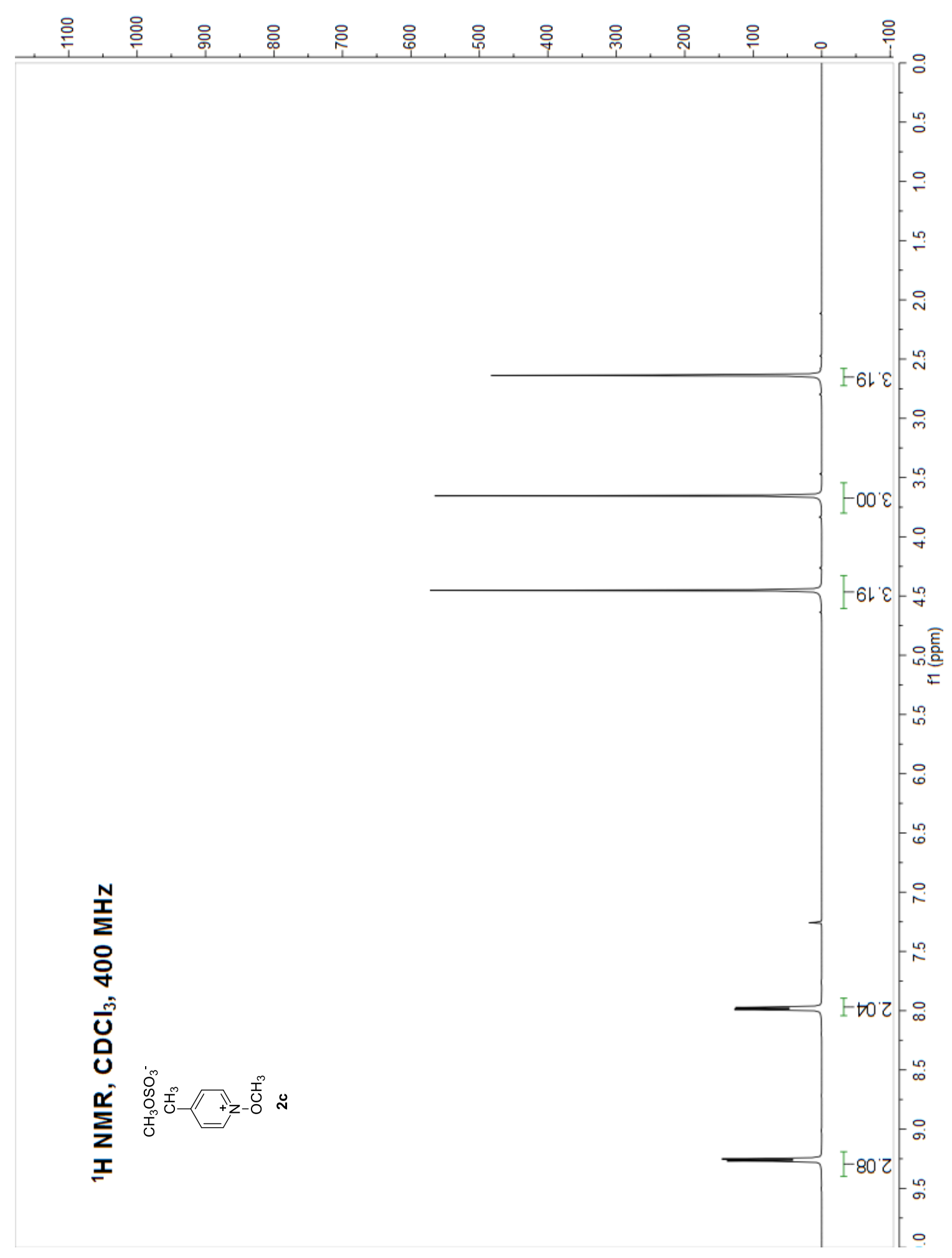




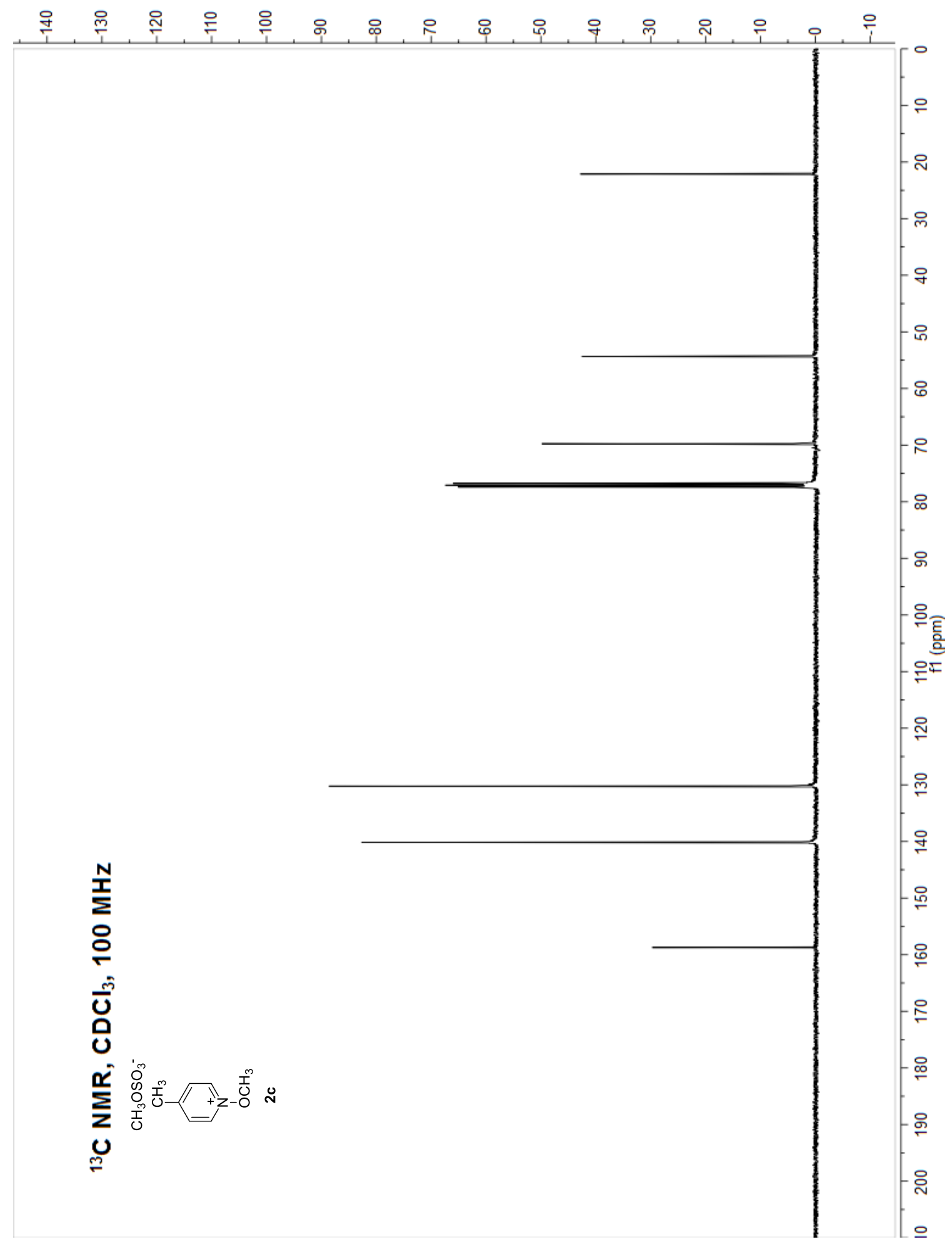




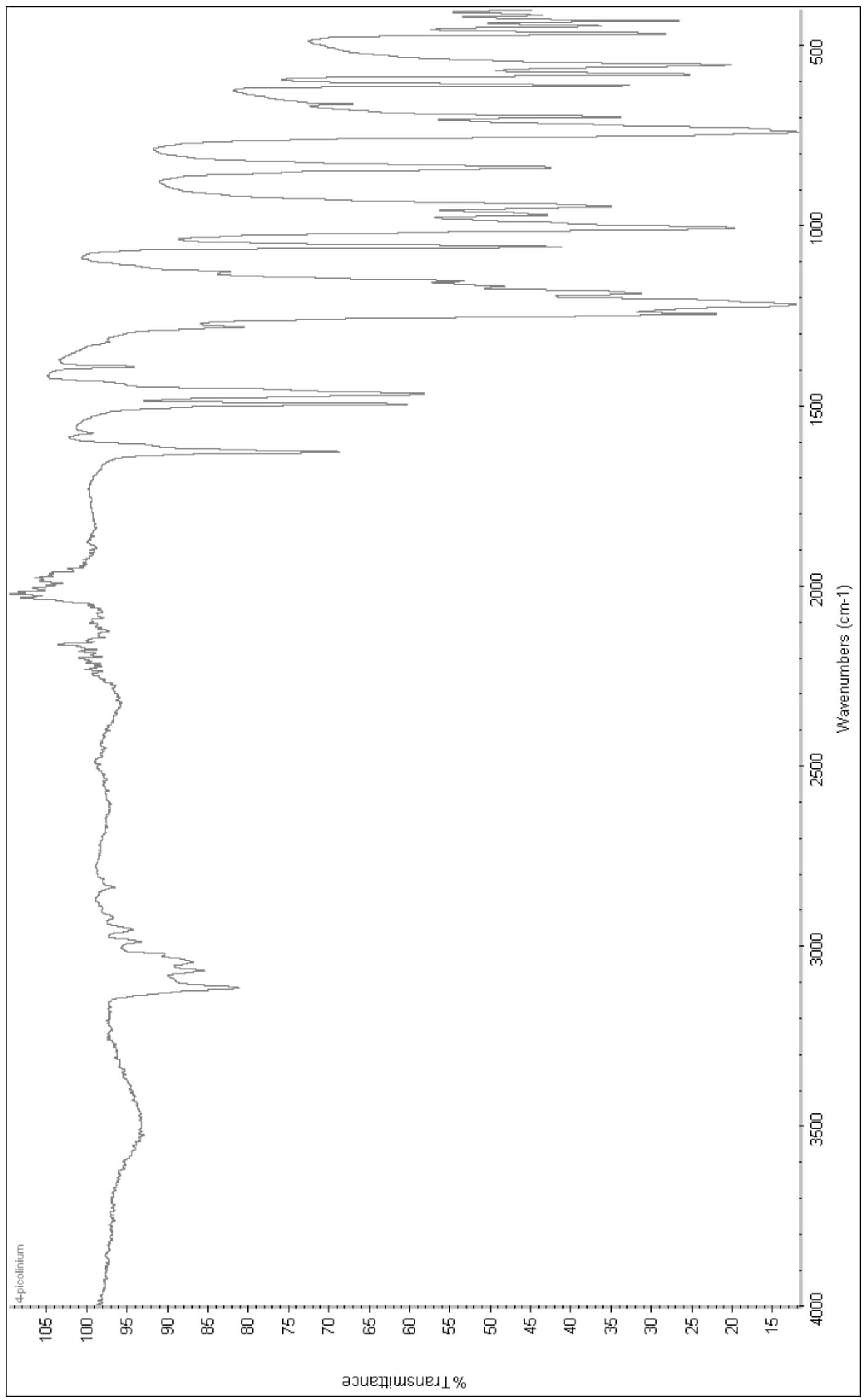

Ma and Herzon "Intermolecular hydropyridylation of unactivated alkenes" J. Am. Chem. Soc. 


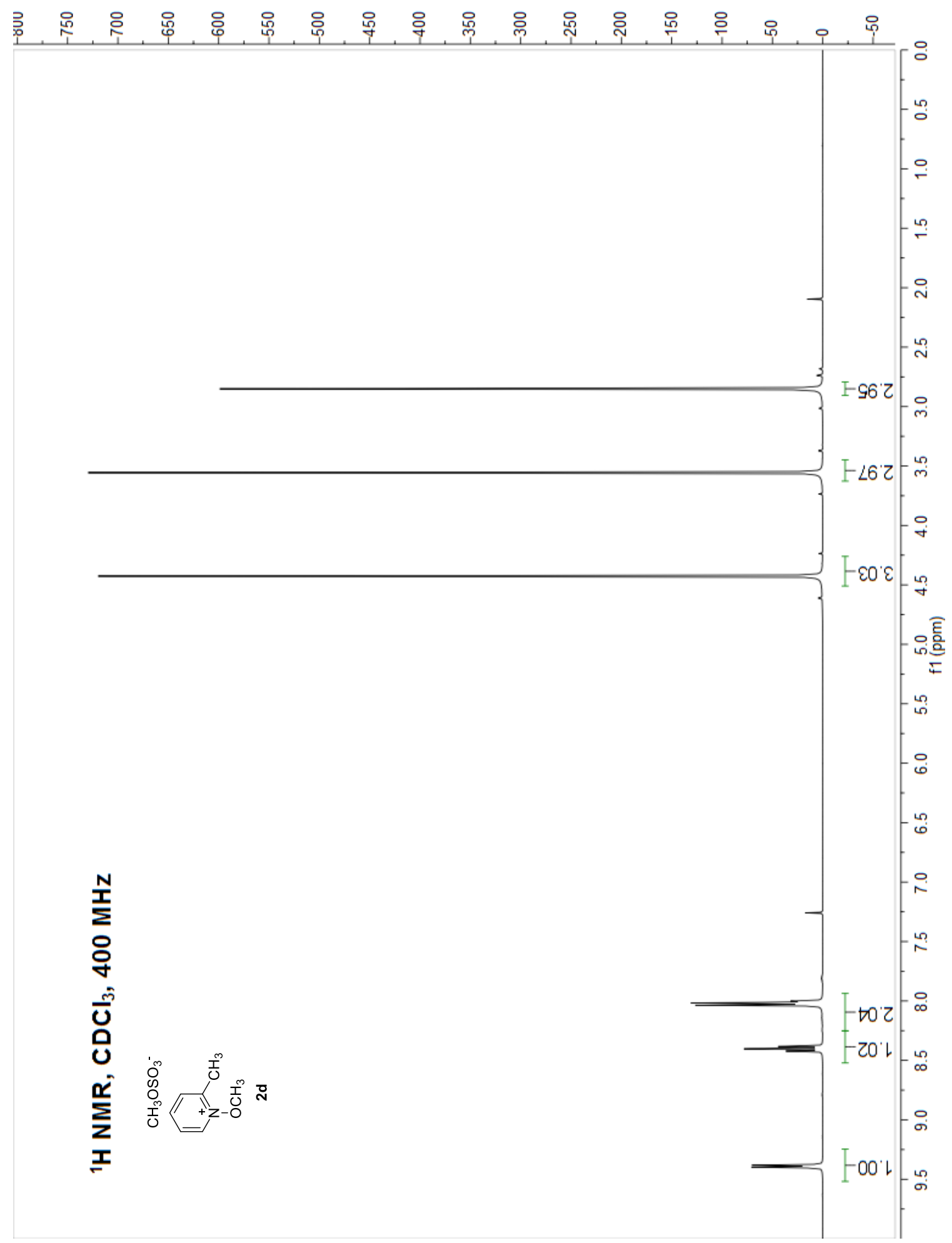




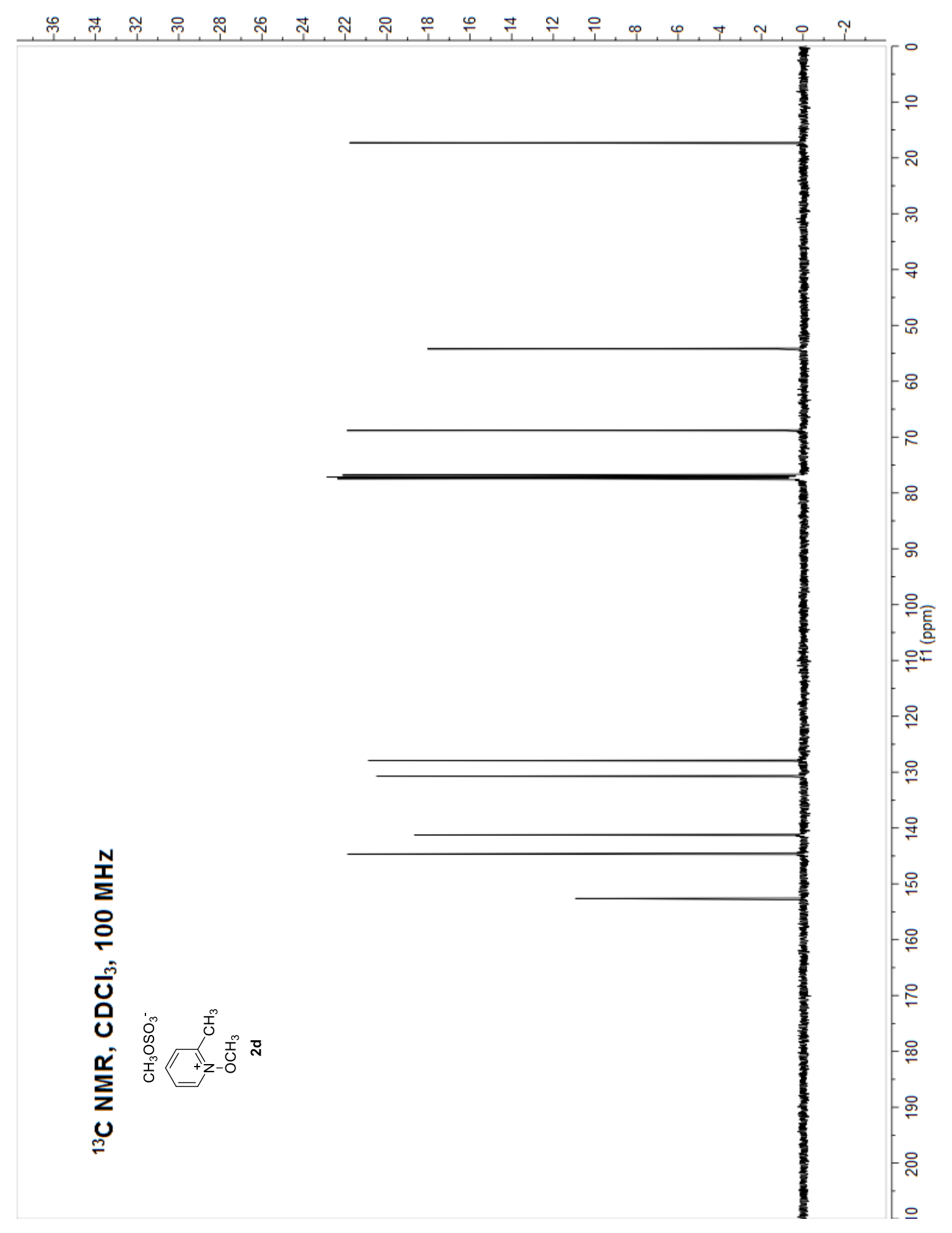




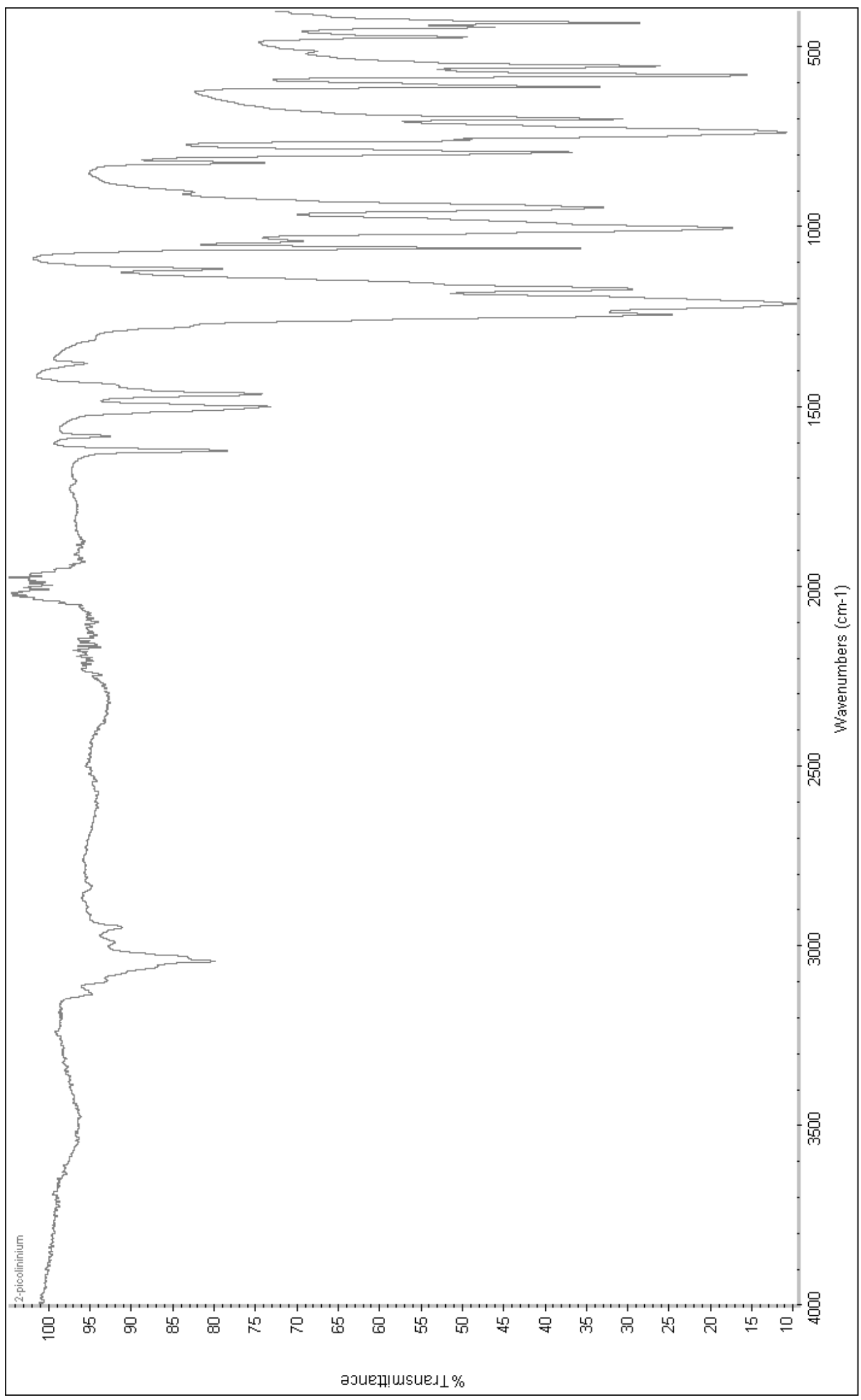

Ma and Herzon "Intermolecular hydropyridylation of unactivated alkenes" J. Am. Chem. Soc. 


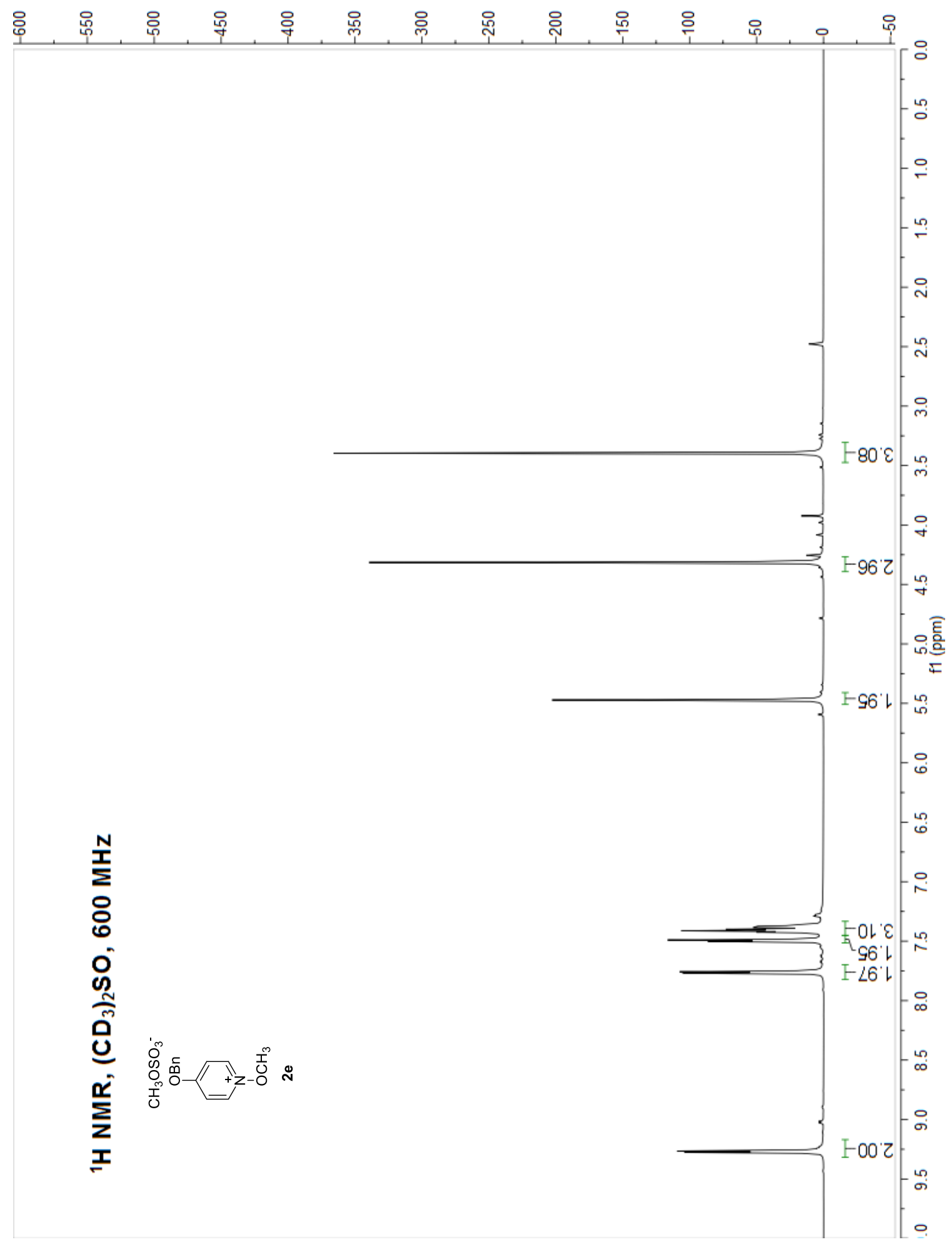




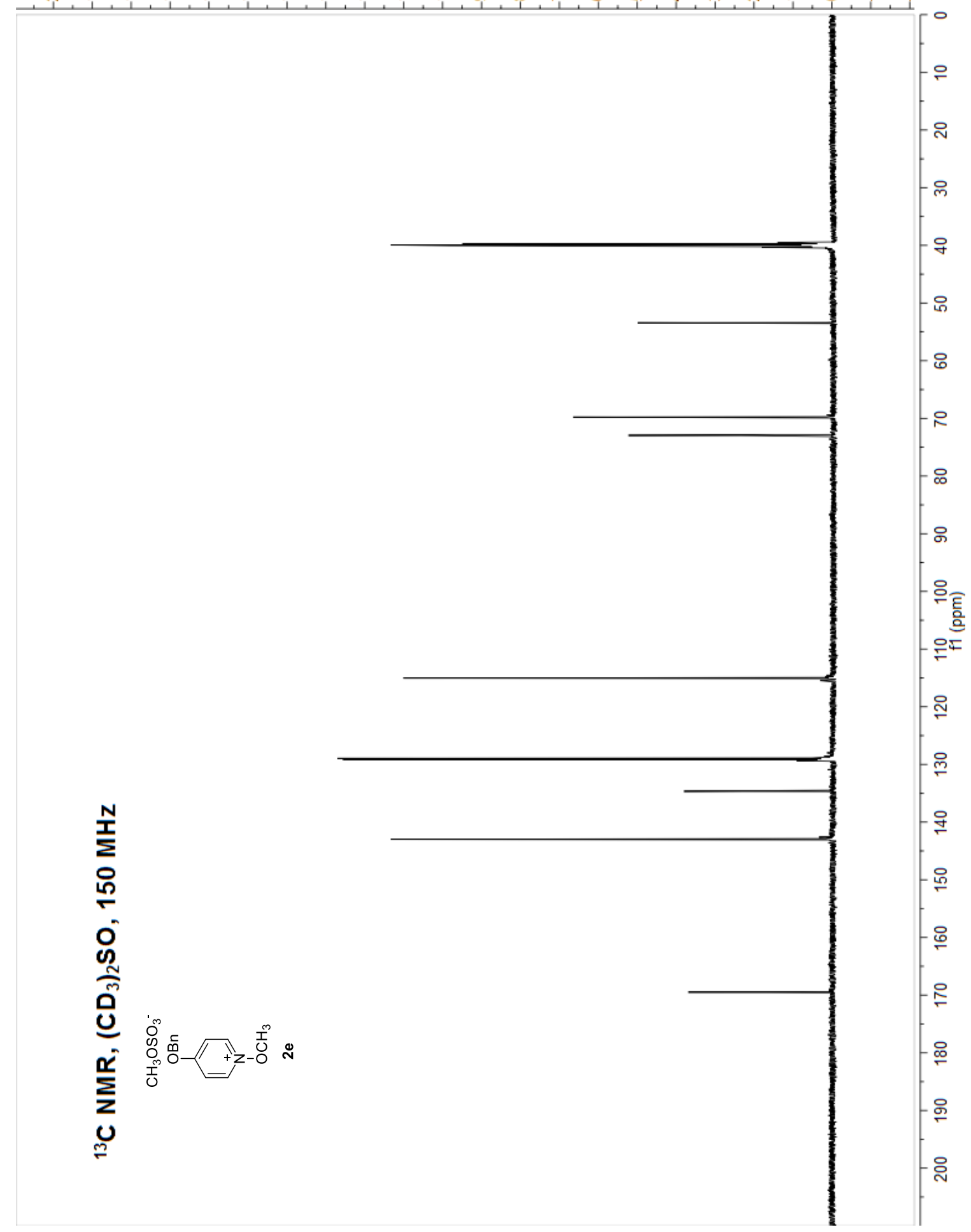




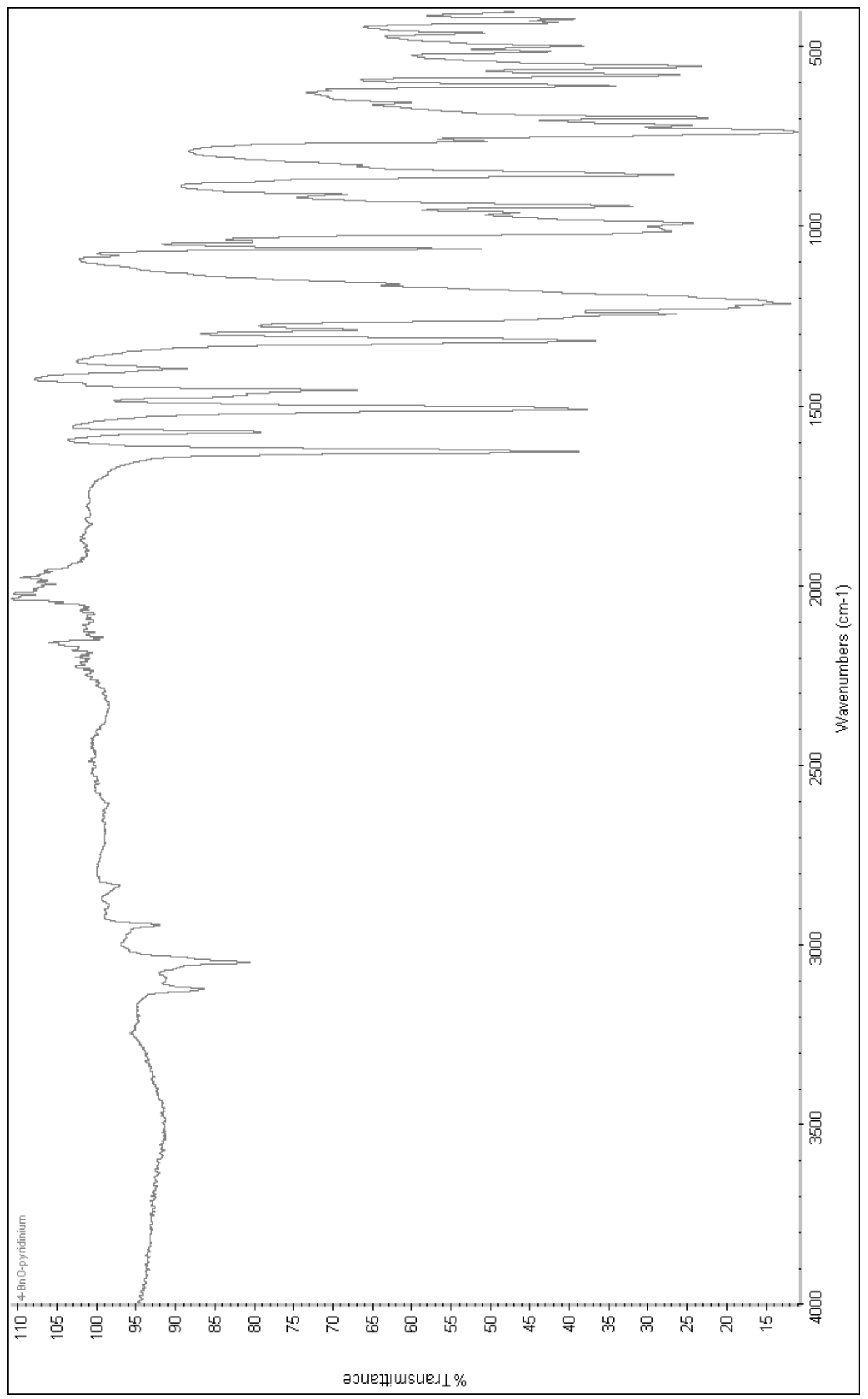

Ma and Herzon "Intermolecular hydropyridylation of unactivated alkenes" J. Am. Chem. Soc. 


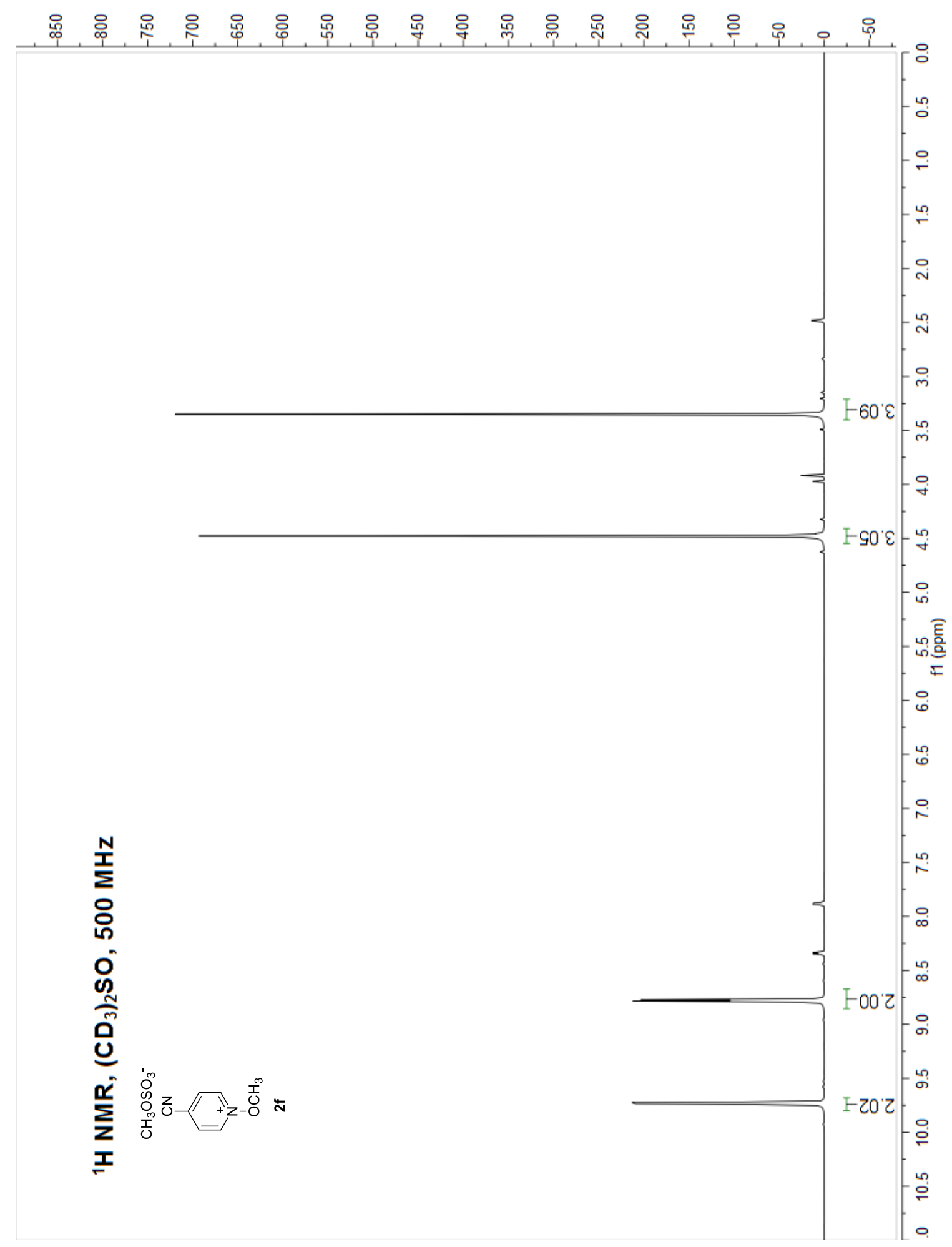




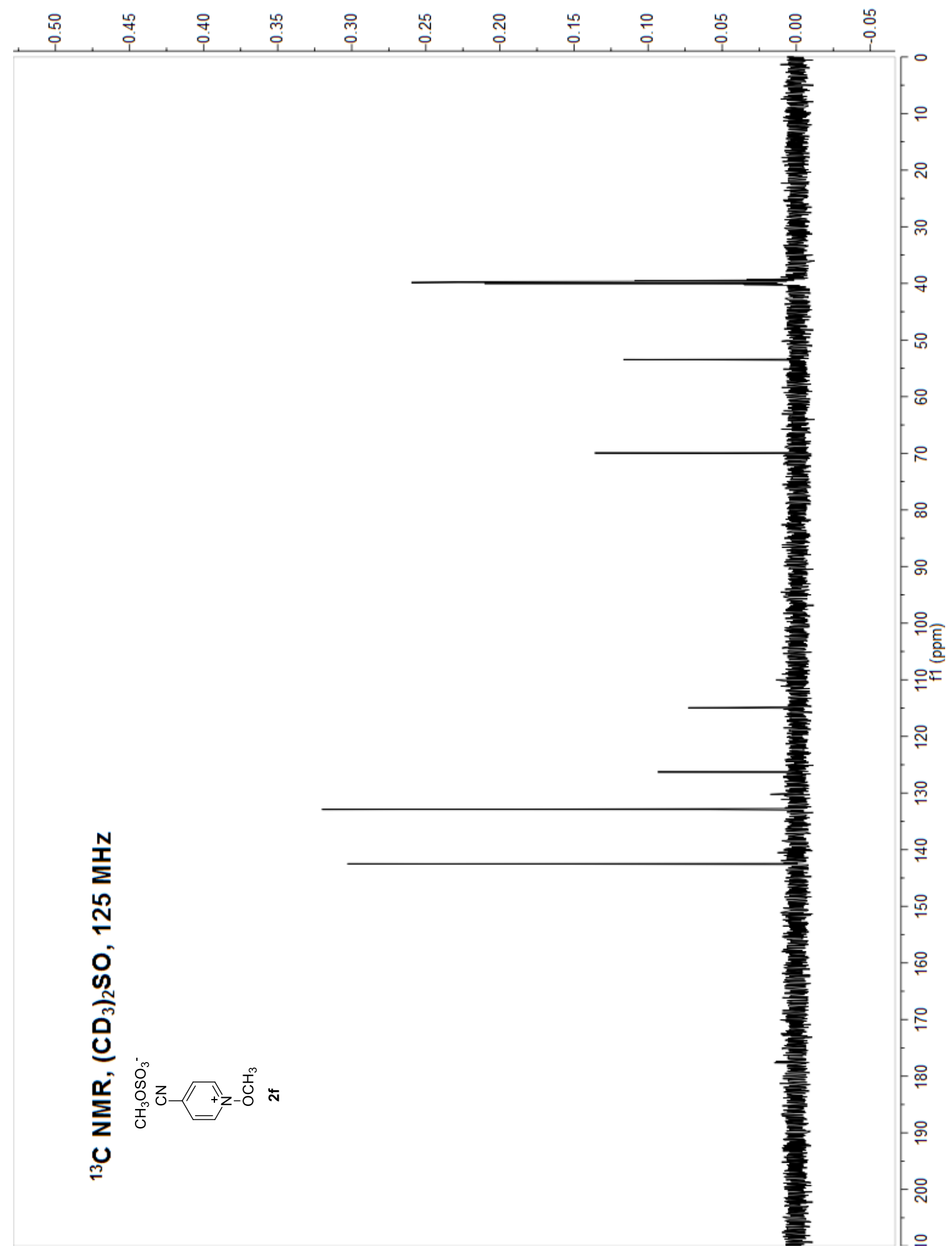




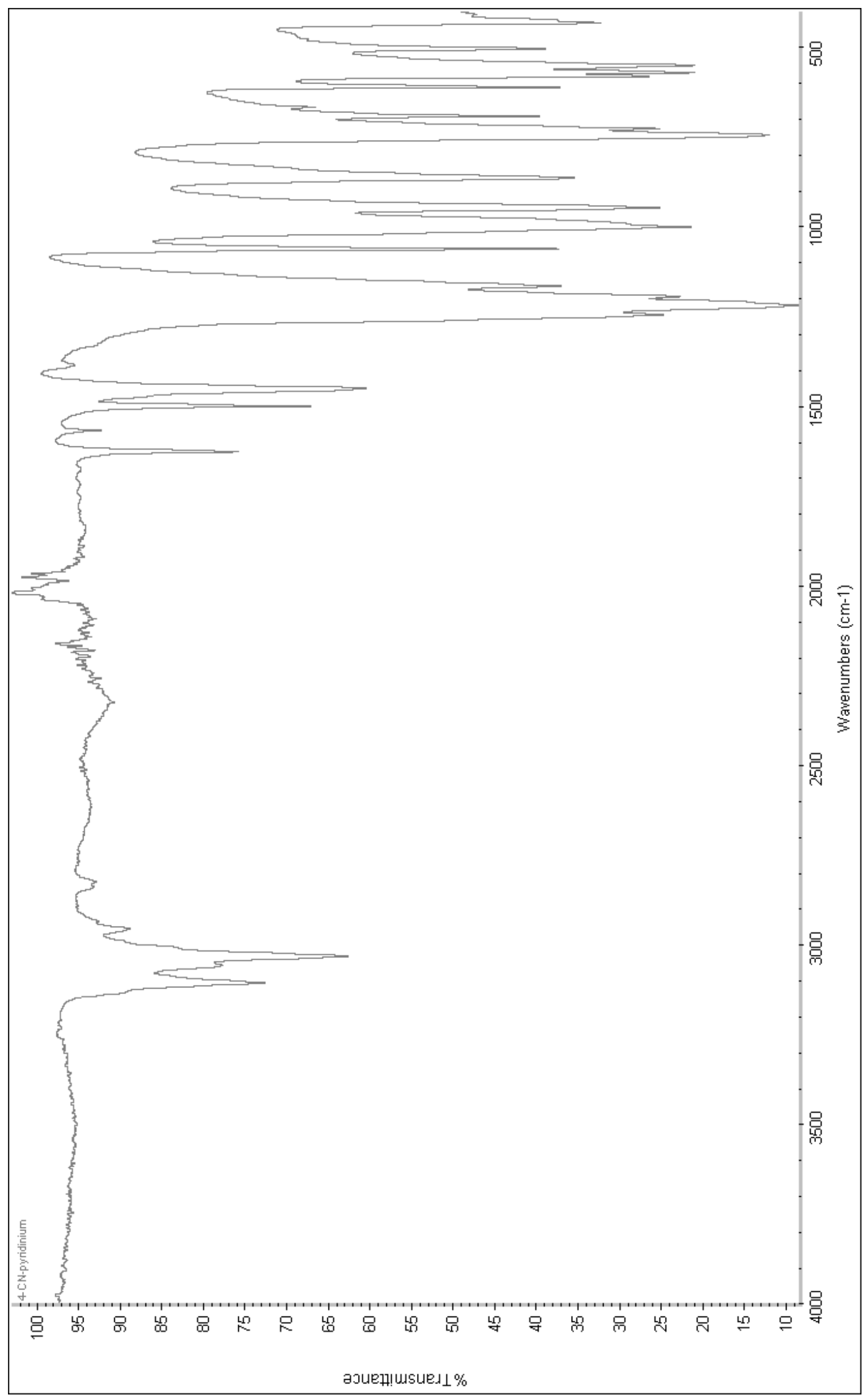

Ma and Herzon "Intermolecular hydropyridylation of unactivated alkenes" J. Am. Chem. Soc. 


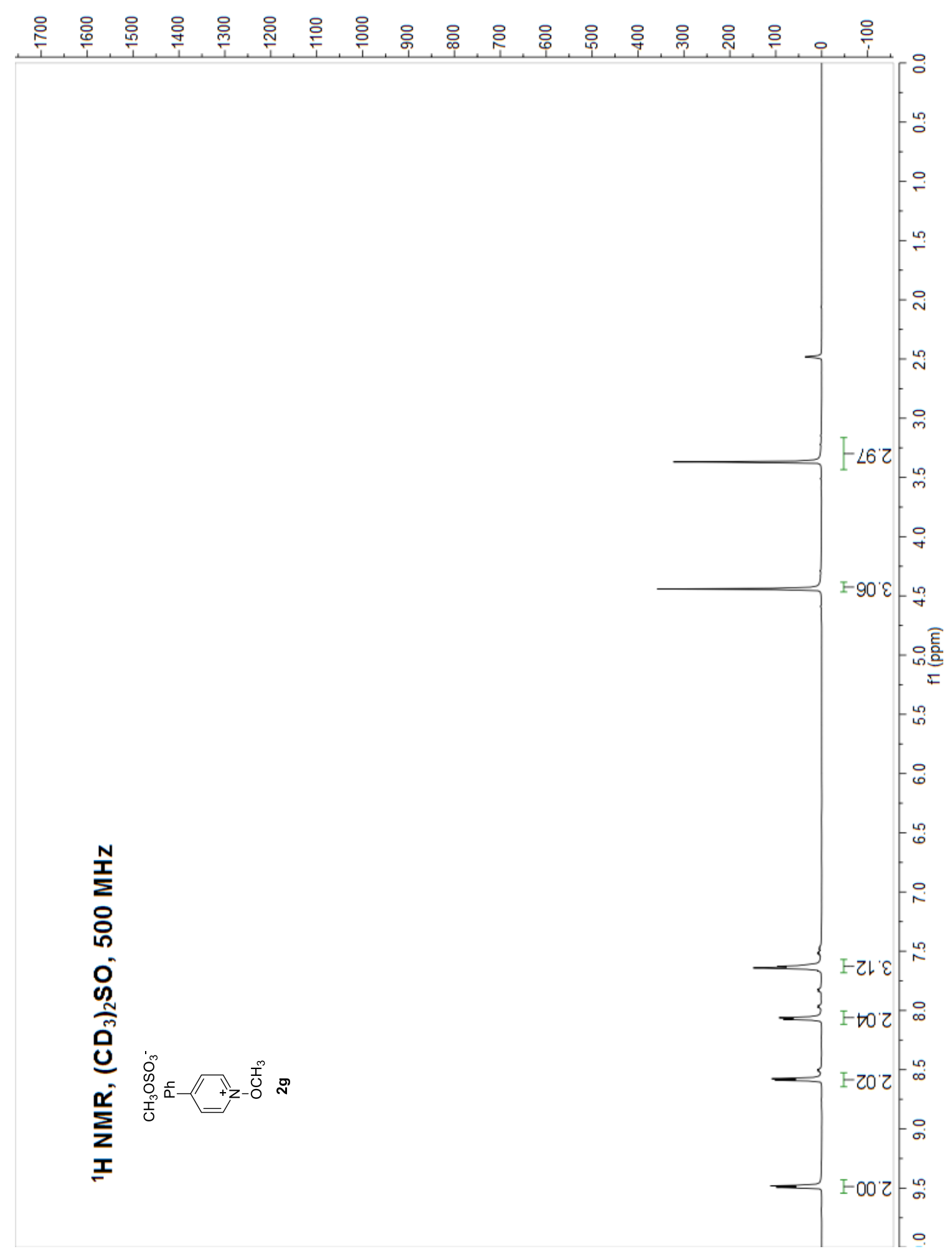




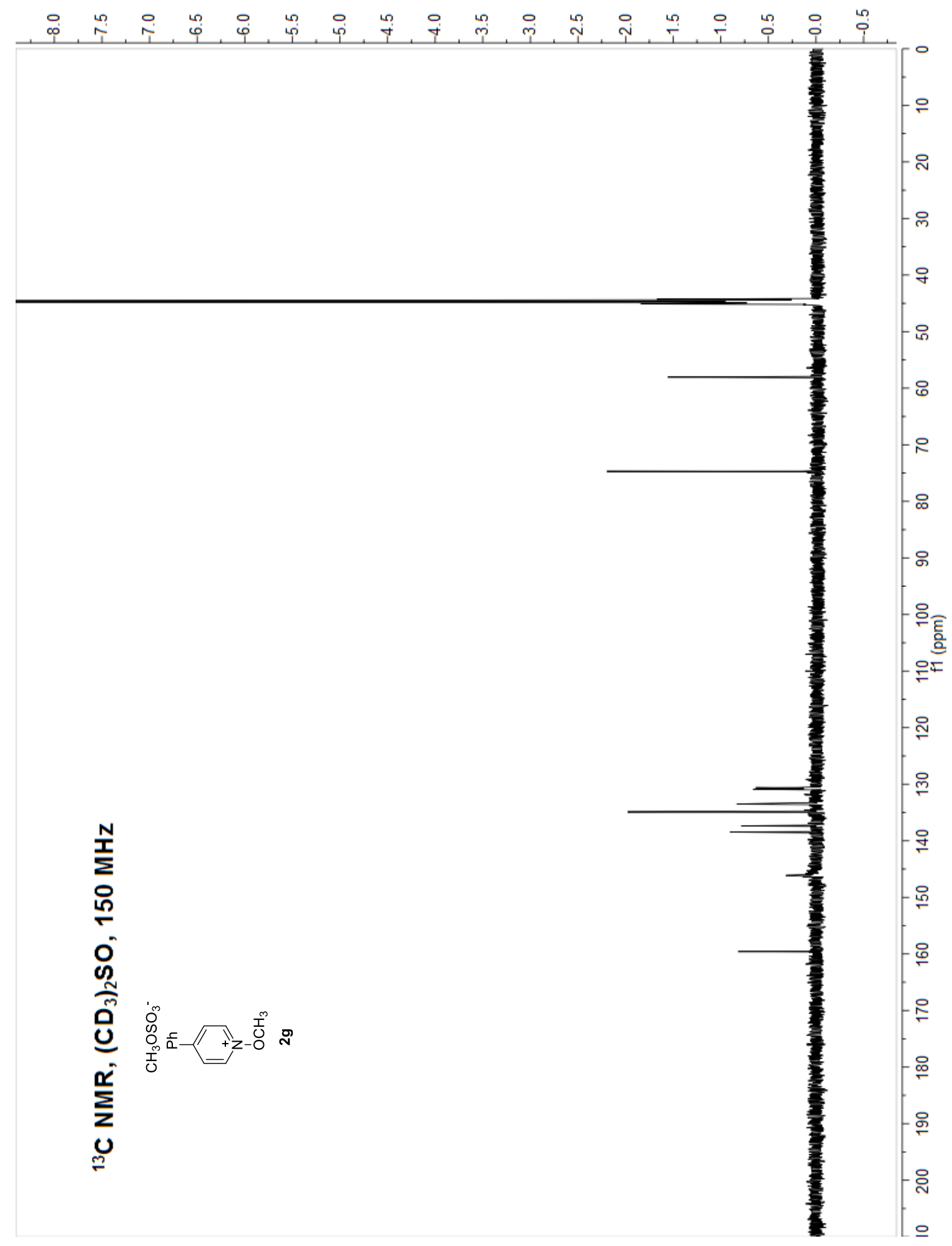




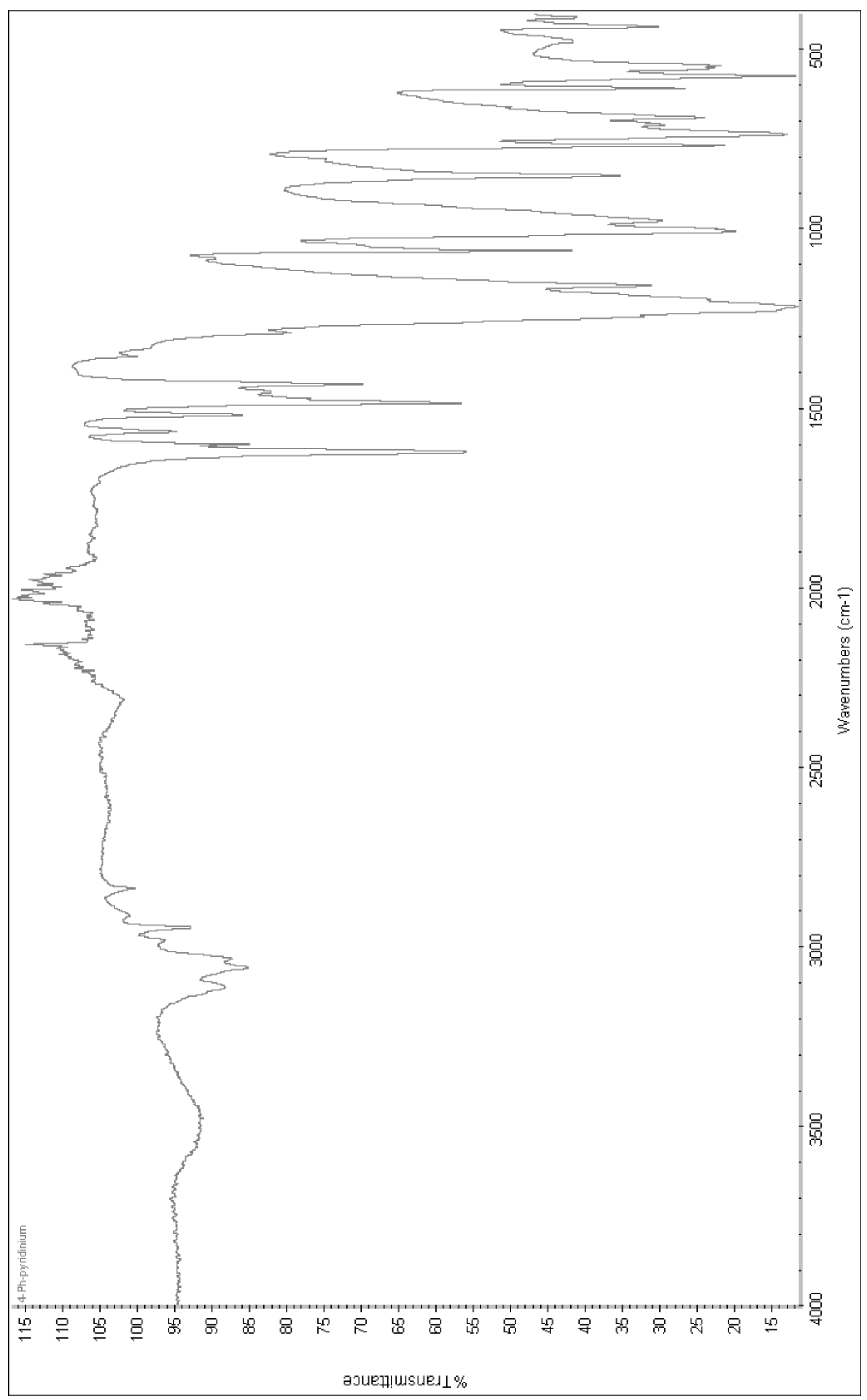

Ma and Herzon "Intermolecular hydropyridylation of unactivated alkenes" J. Am. Chem. Soc. 


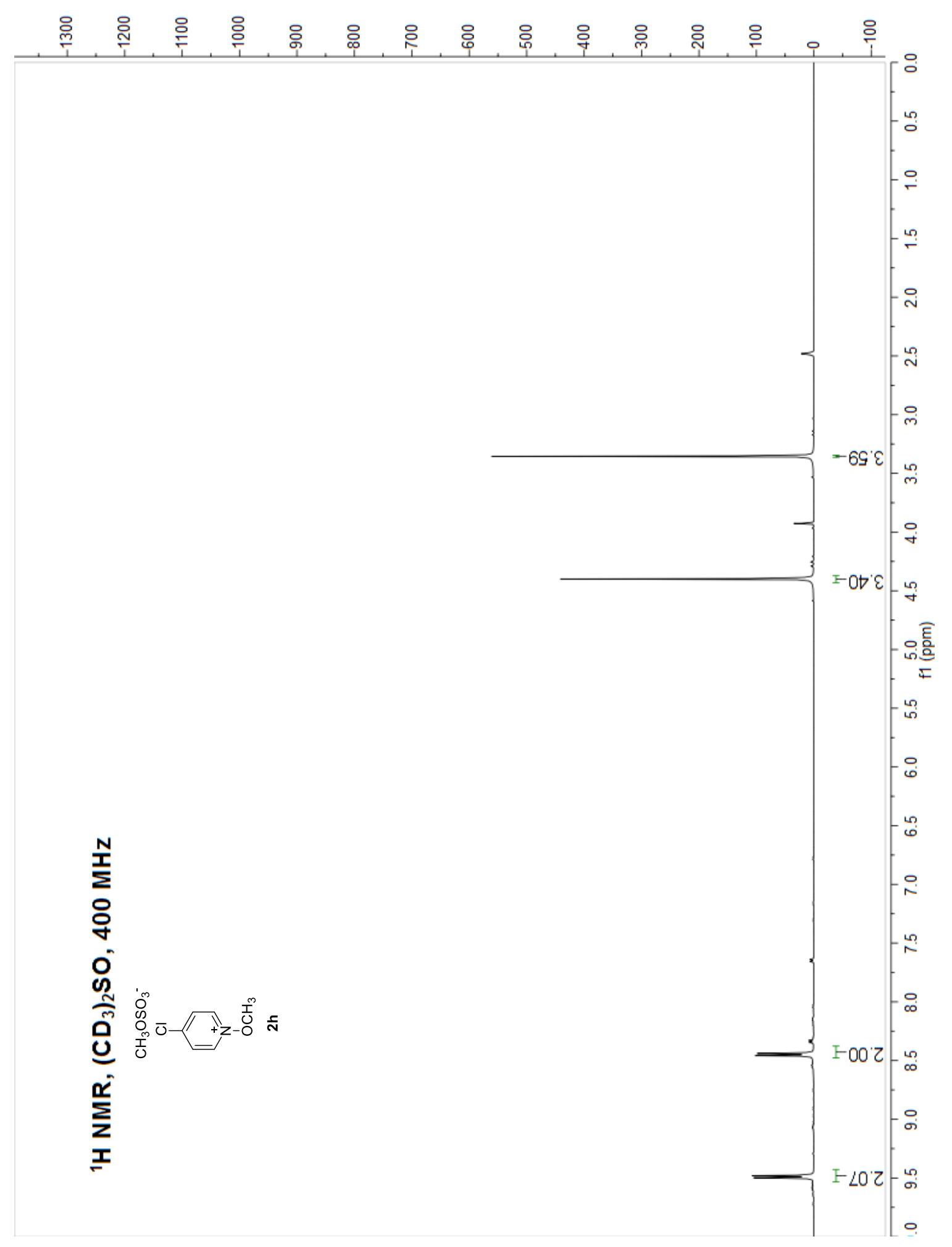




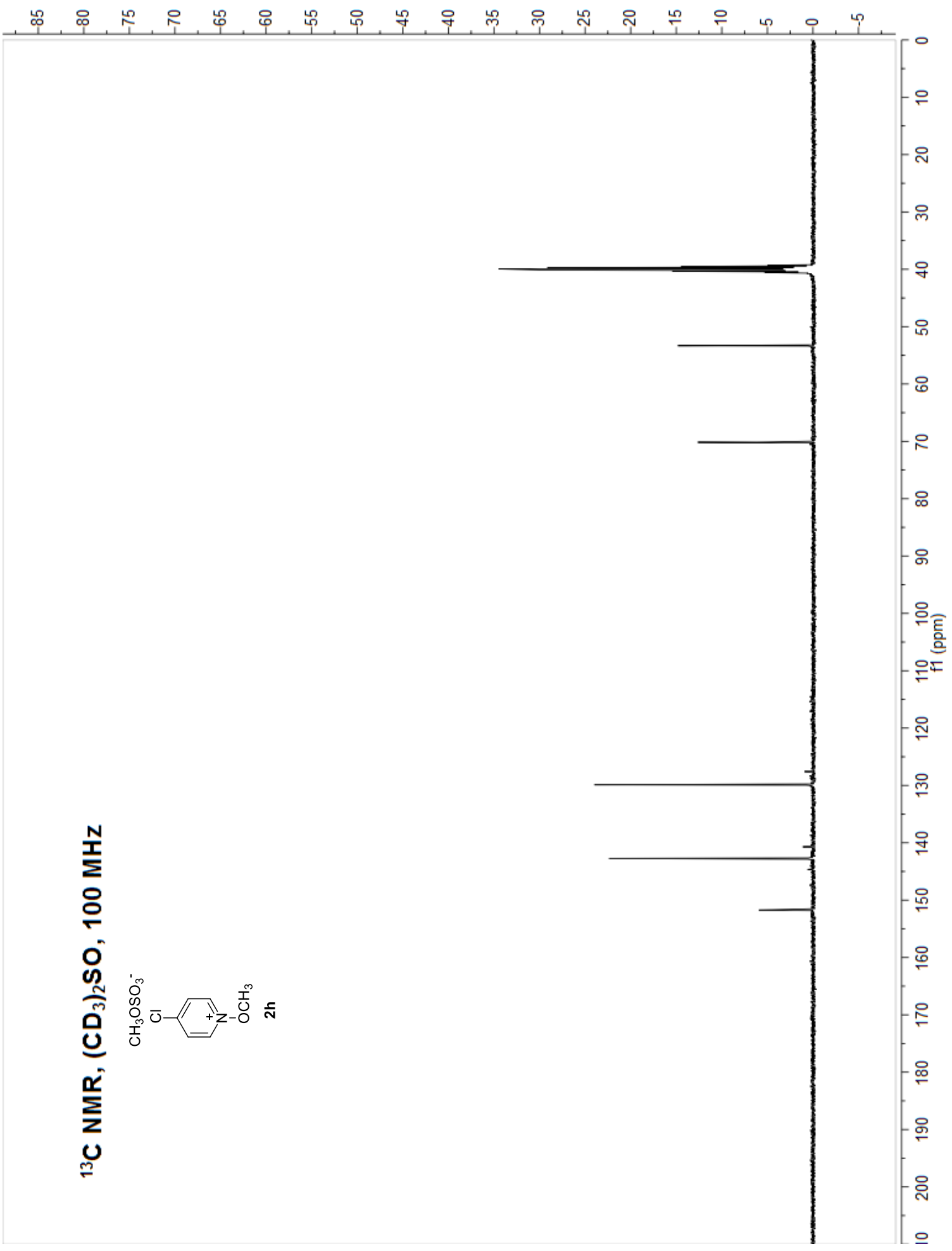




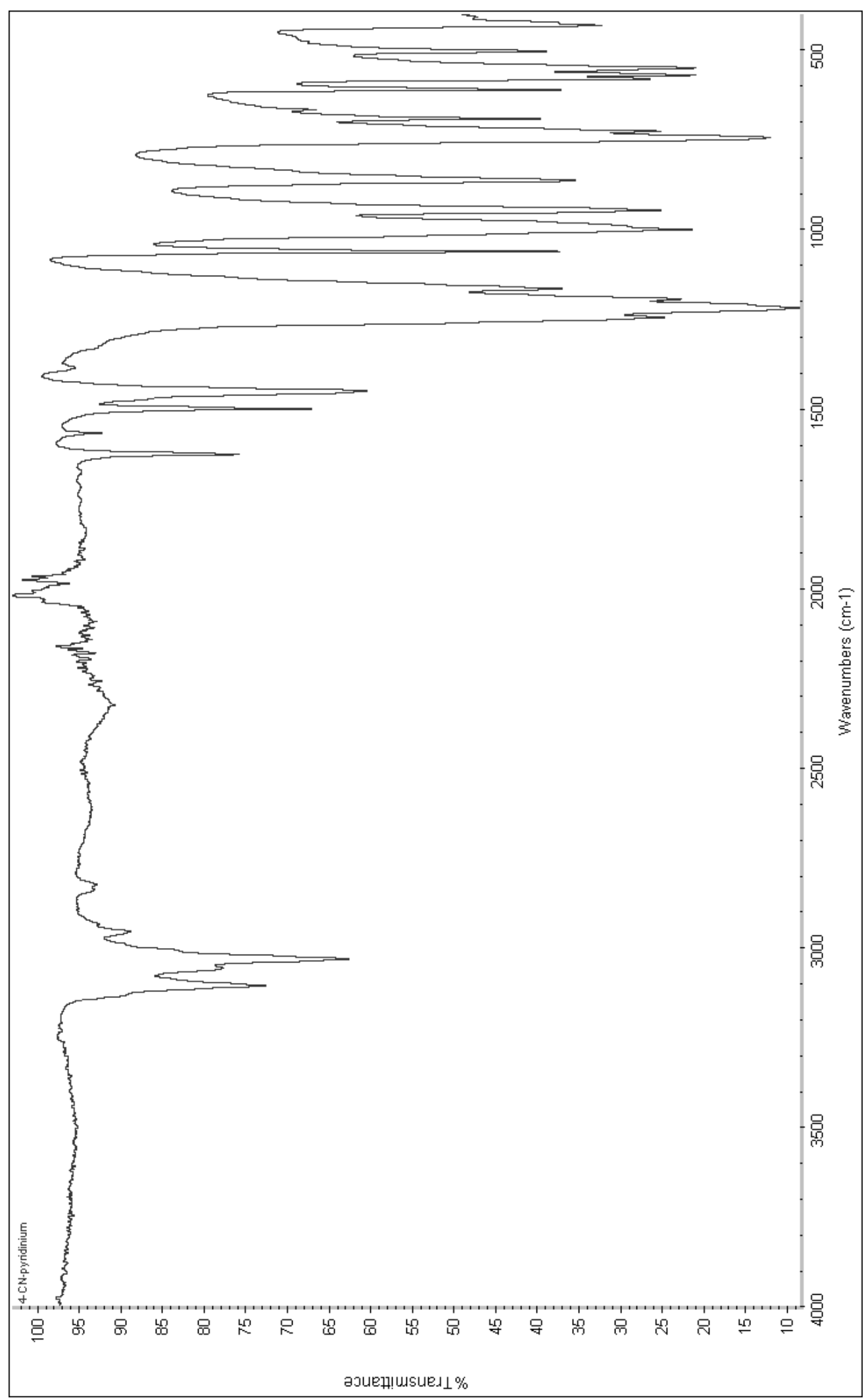




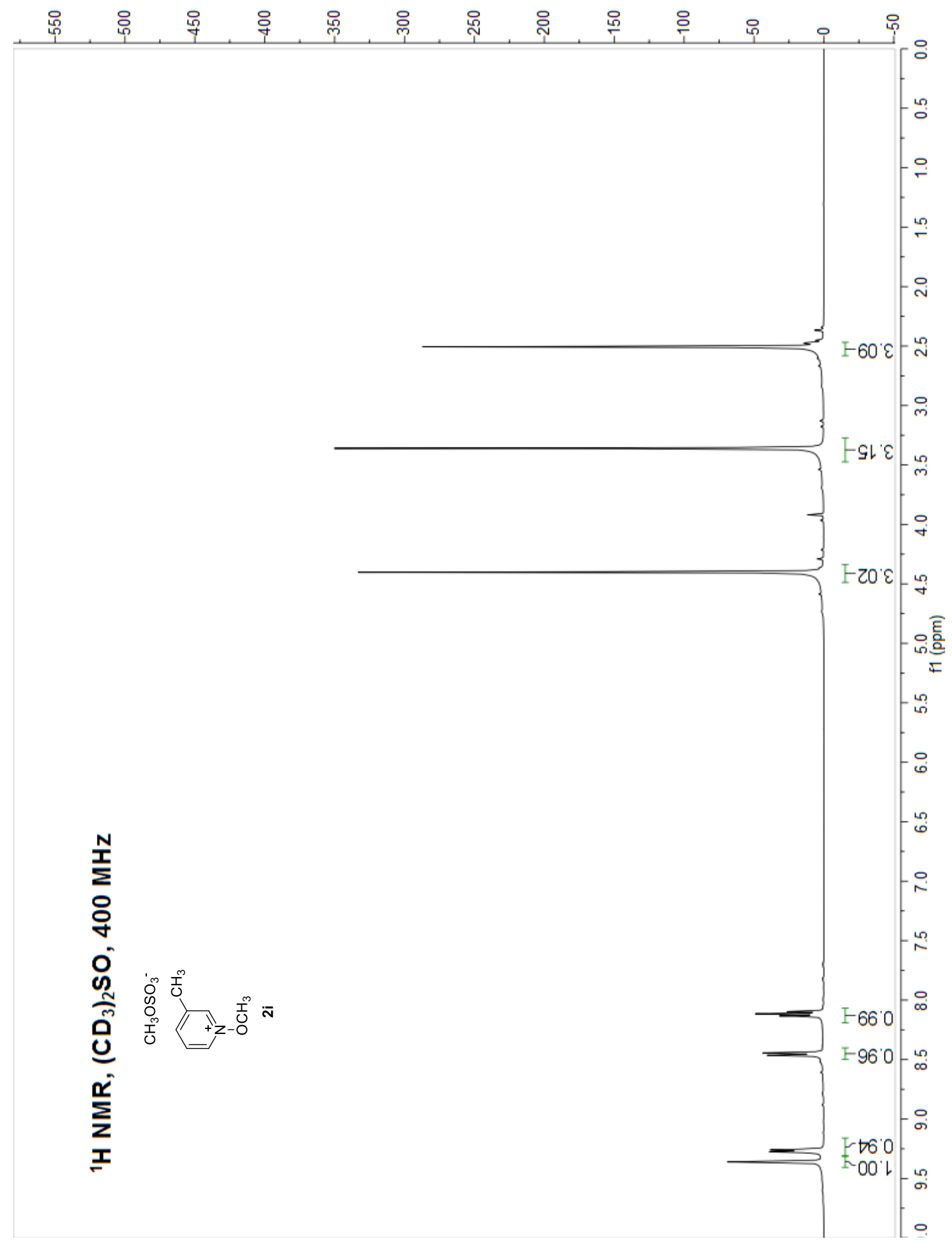




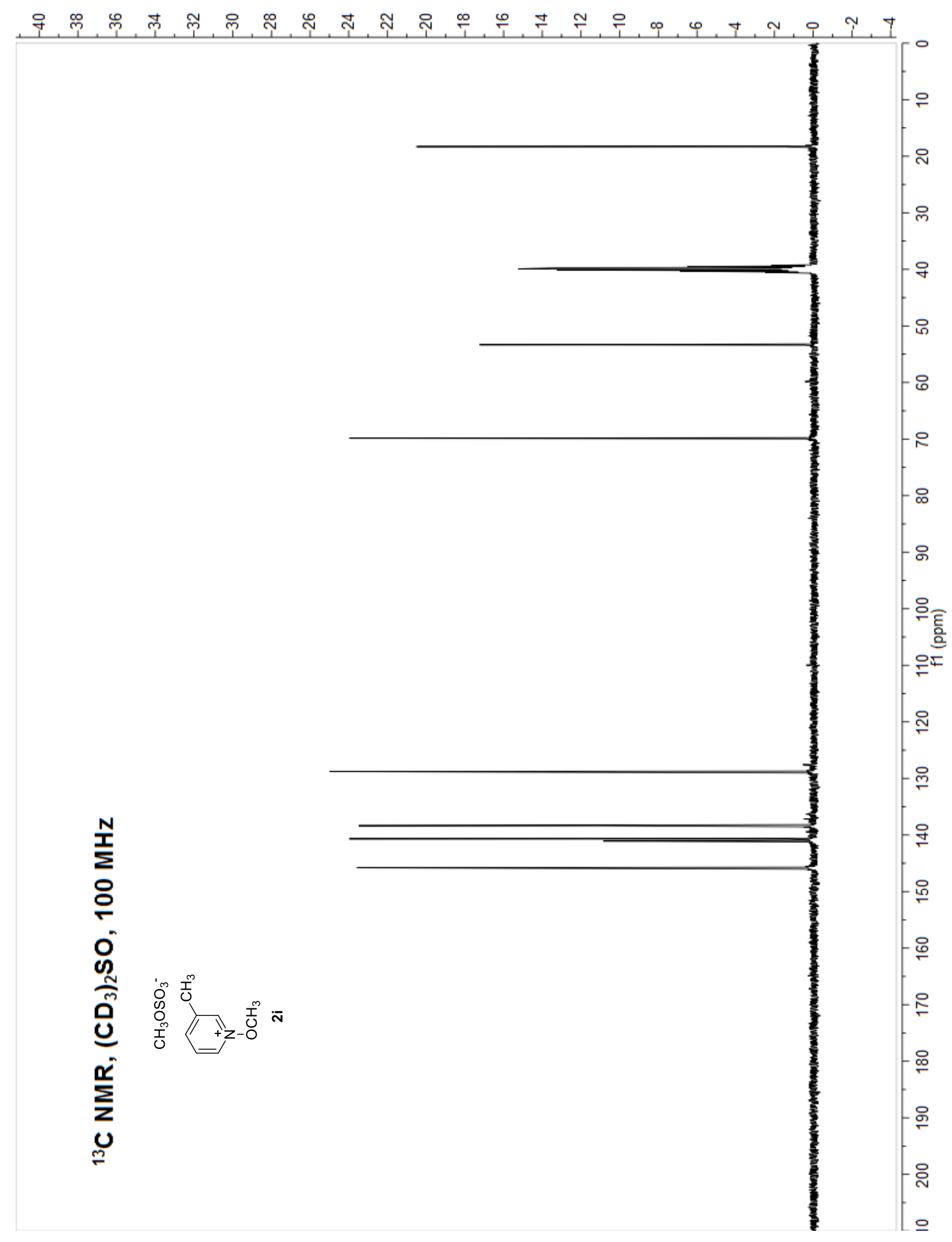

Ma and Herzon "Intermolecular hydropyridylation of unactivated alkenes" J. Am. Chem. Soc. 


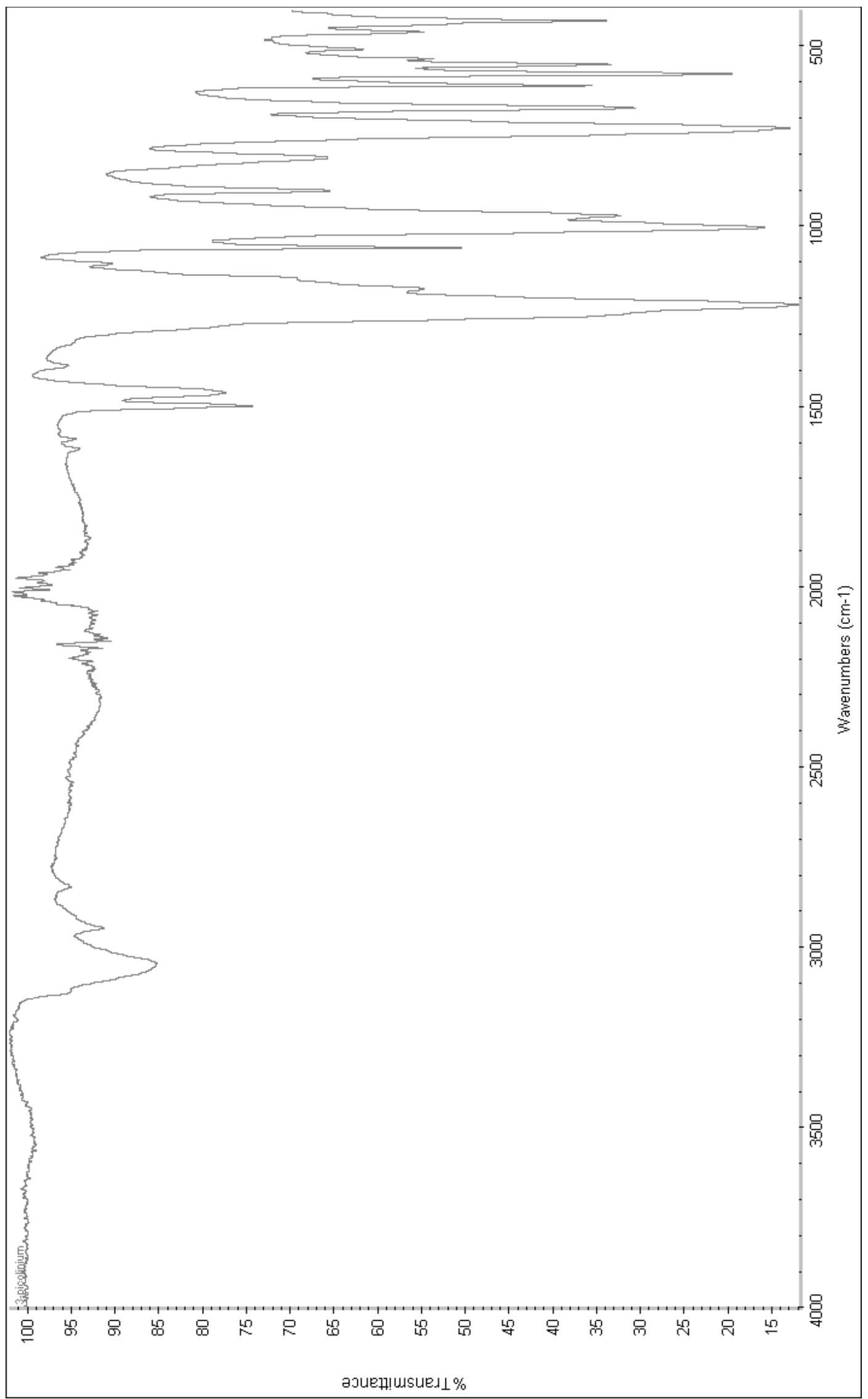

Ma and Herzon "Intermolecular hydropyridylation of unactivated alkenes" J. Am. Chem. Soc. 


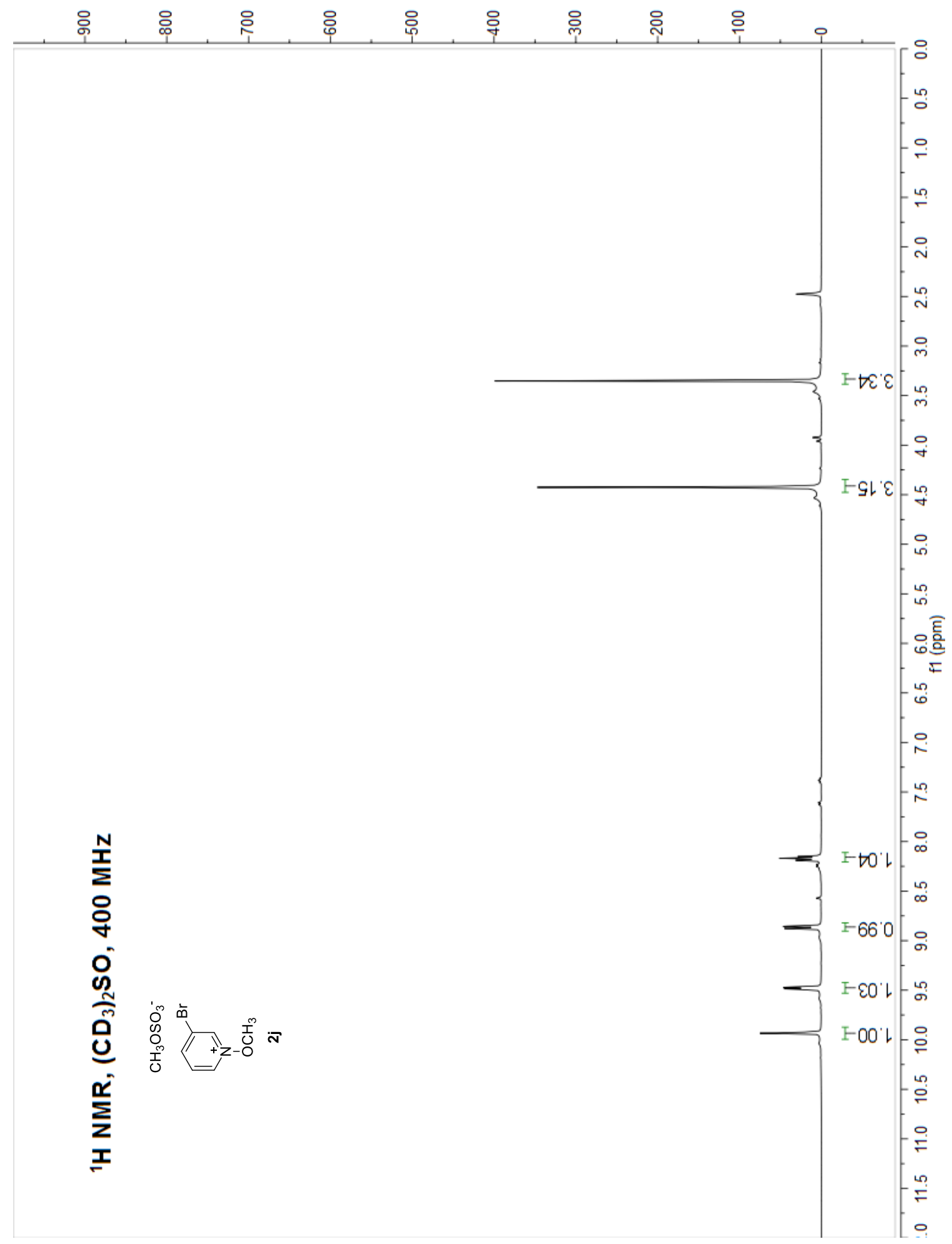




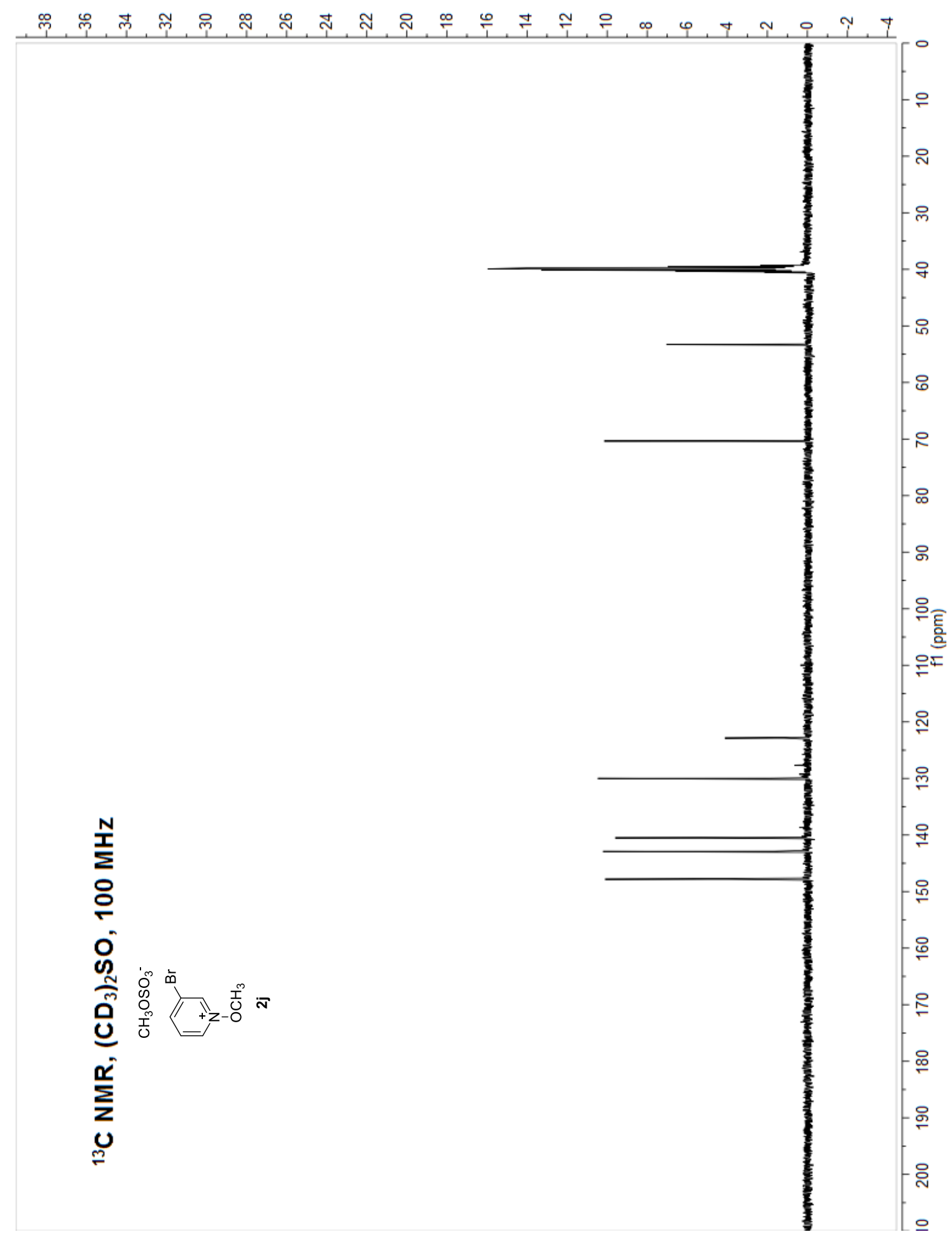




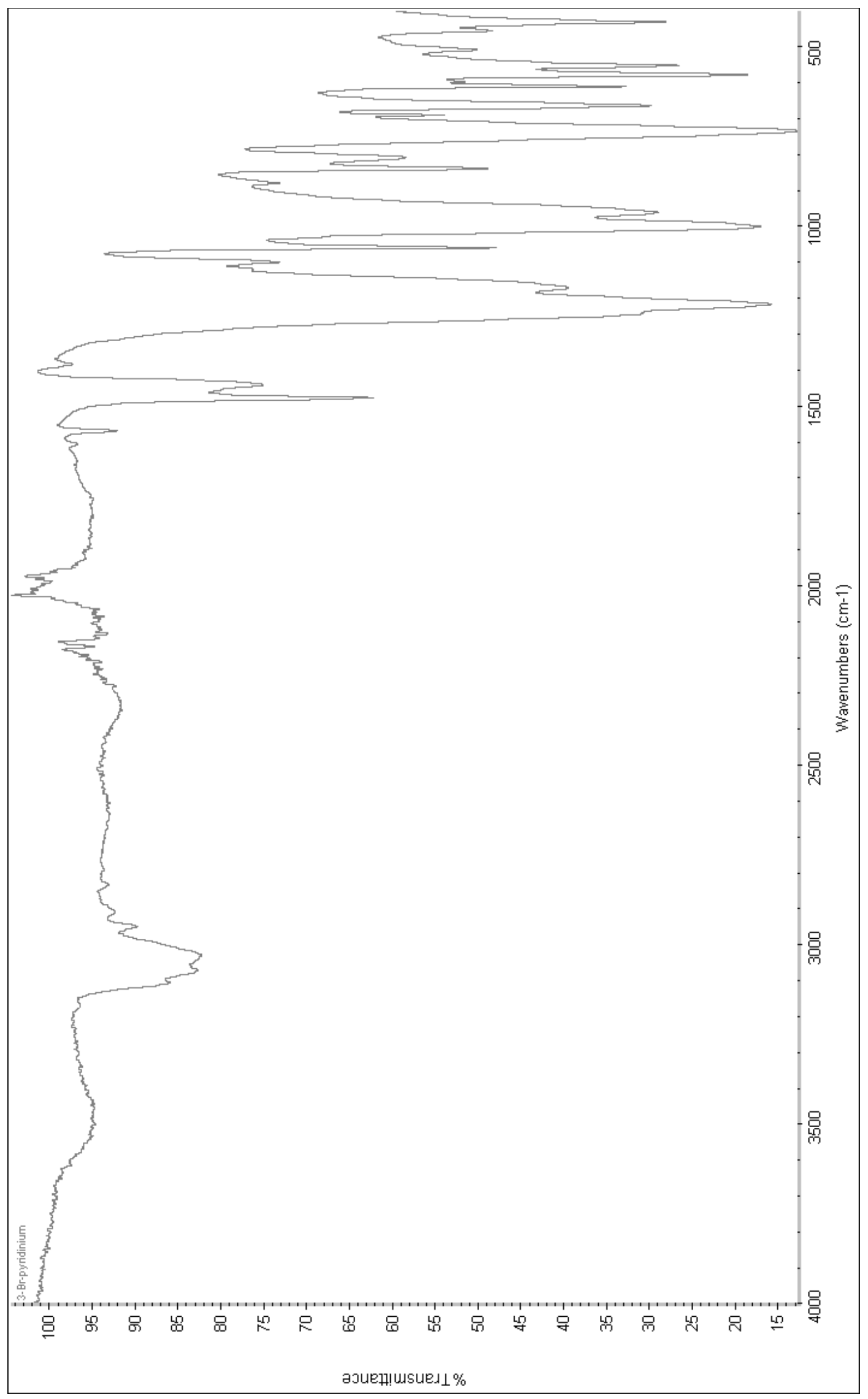

Ma and Herzon "Intermolecular hydropyridylation of unactivated alkenes" J. Am. Chem. Soc. 


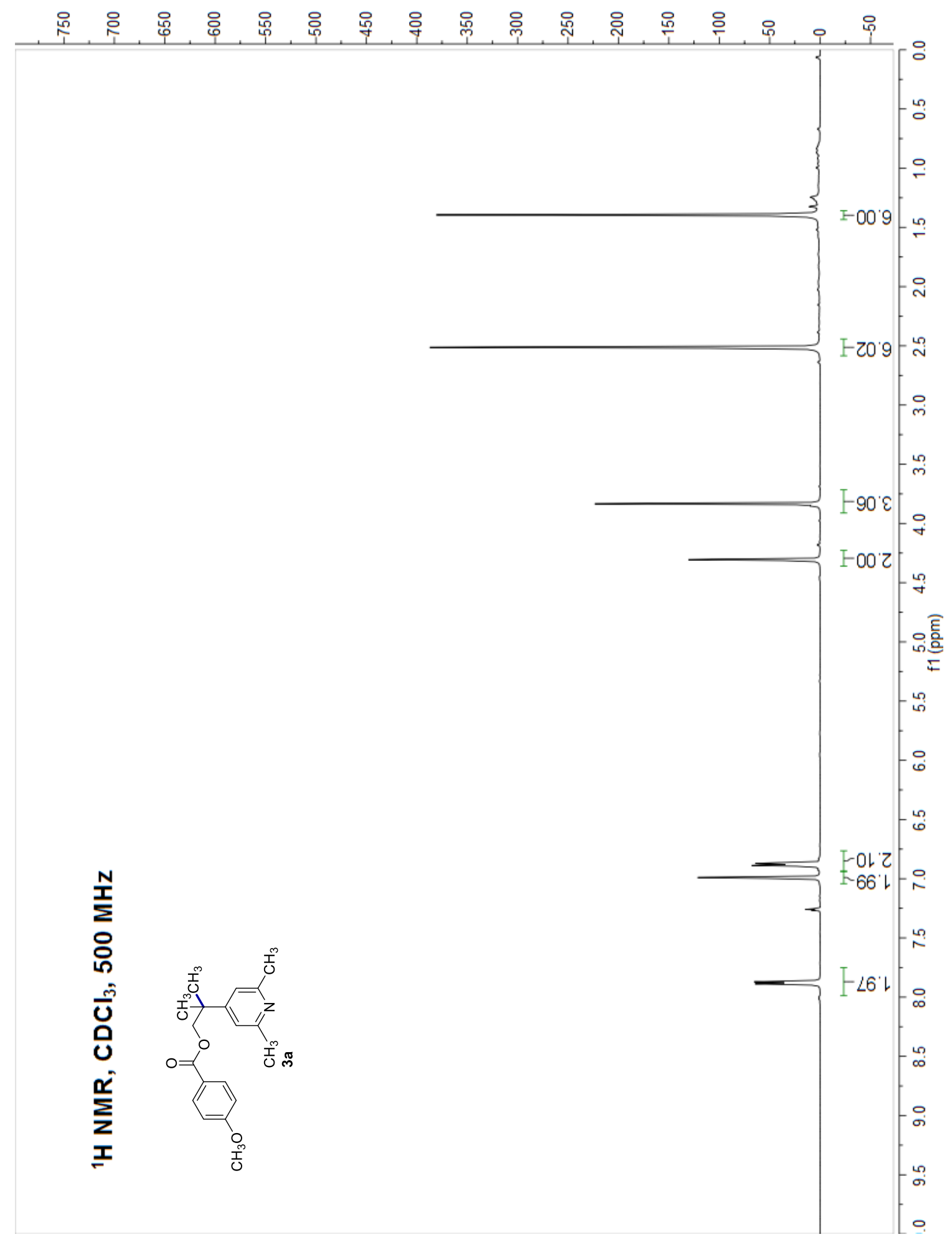




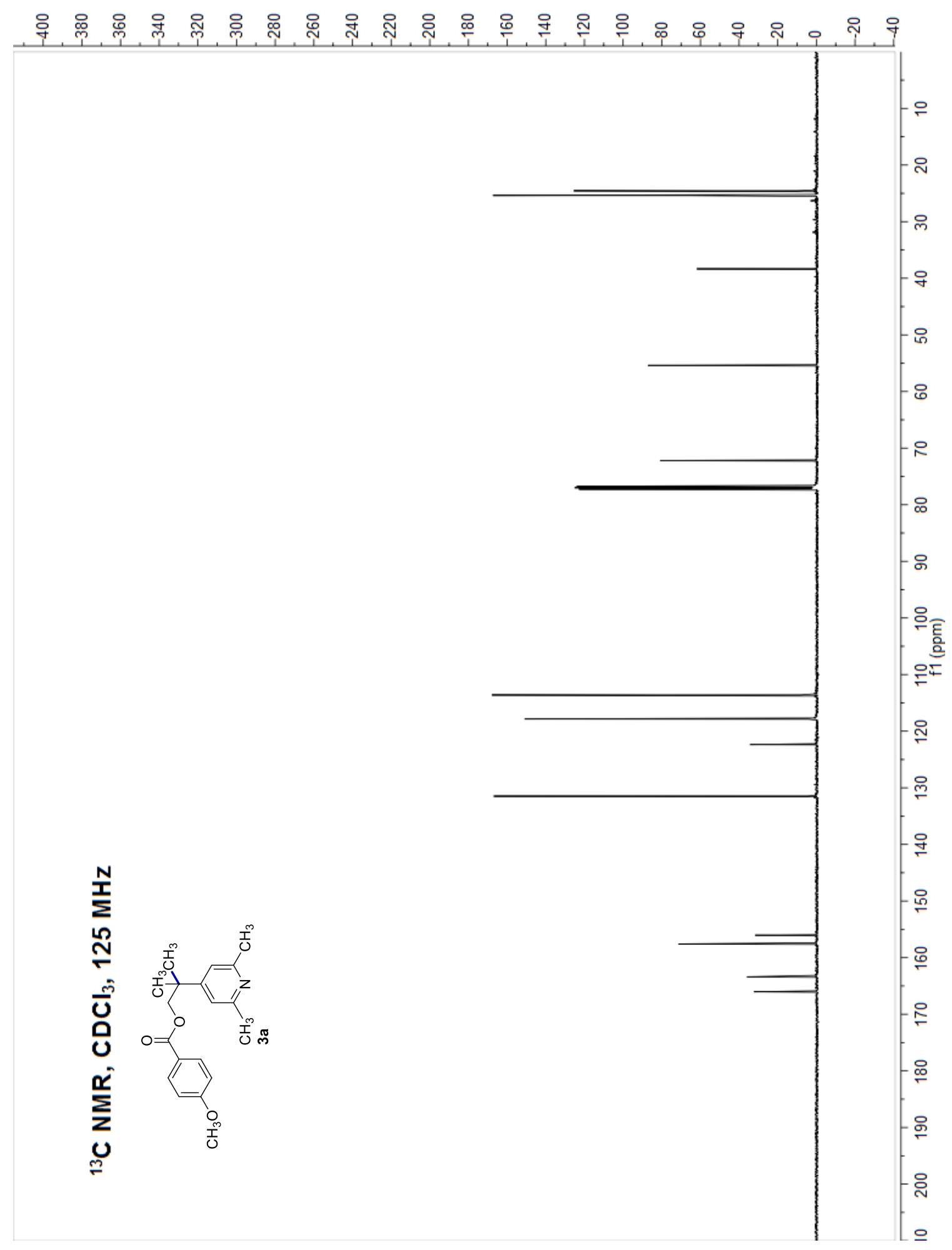




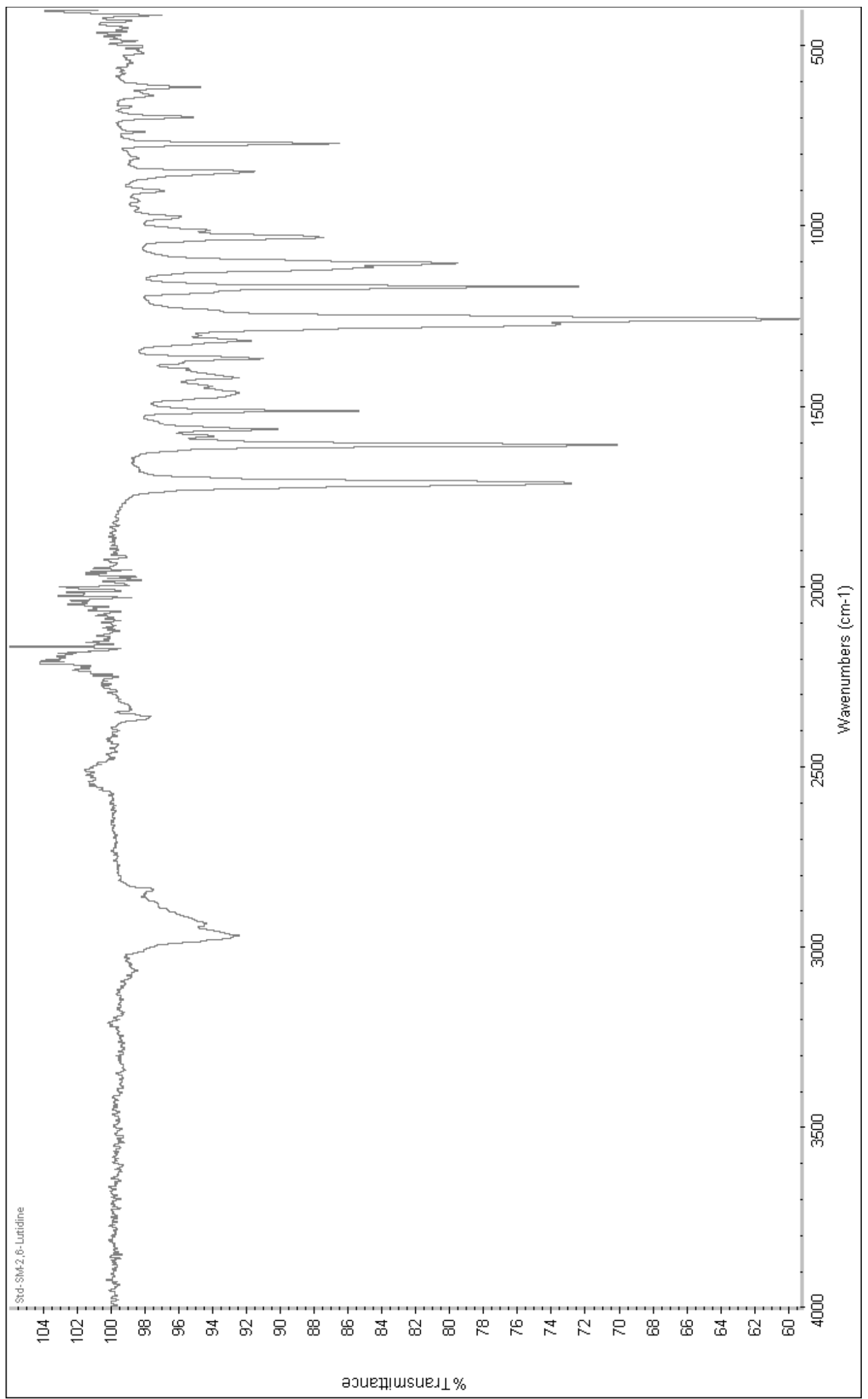

Ma and Herzon "Intermolecular hydropyridylation of unactivated alkenes" J. Am. Chem. Soc. 


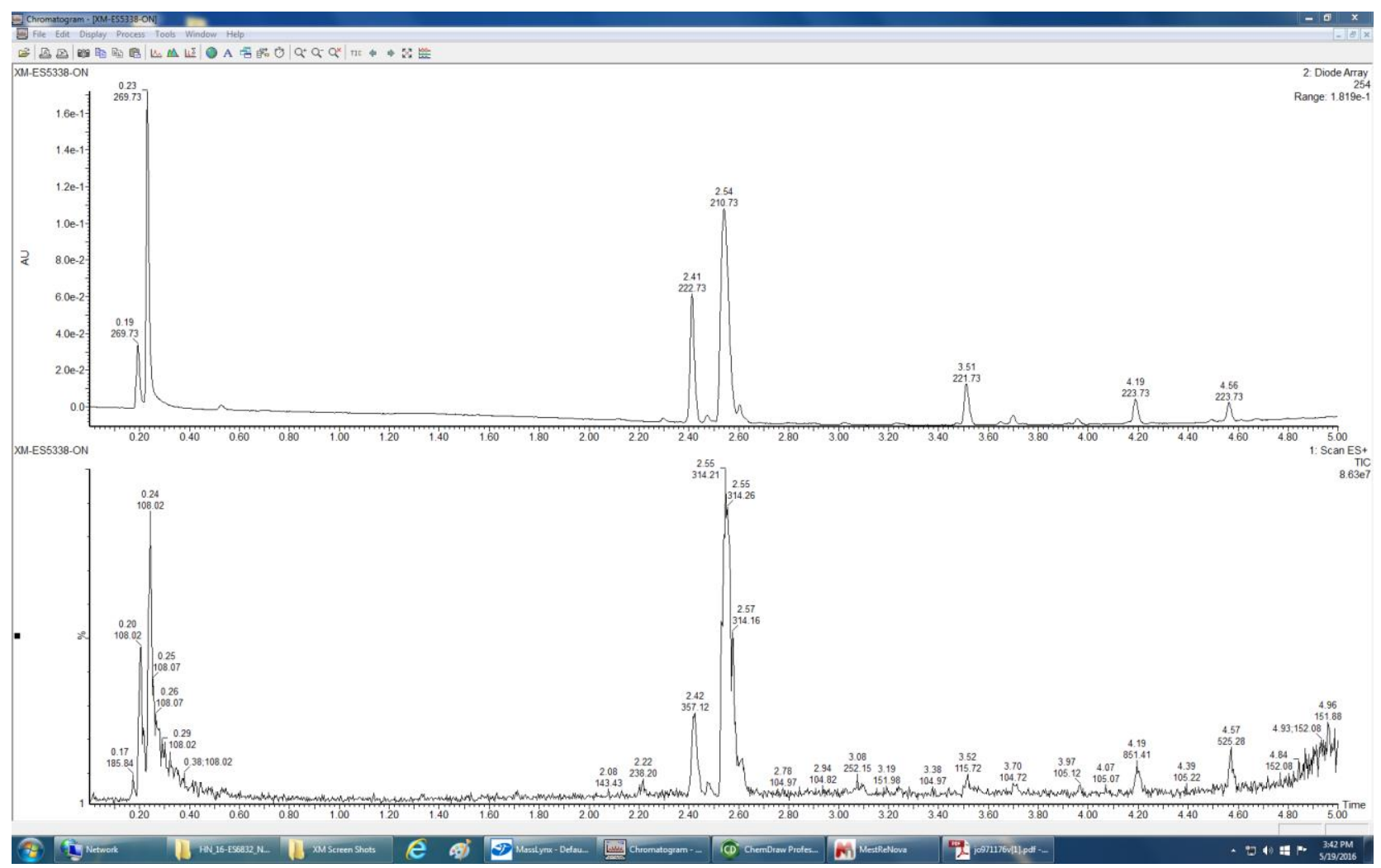




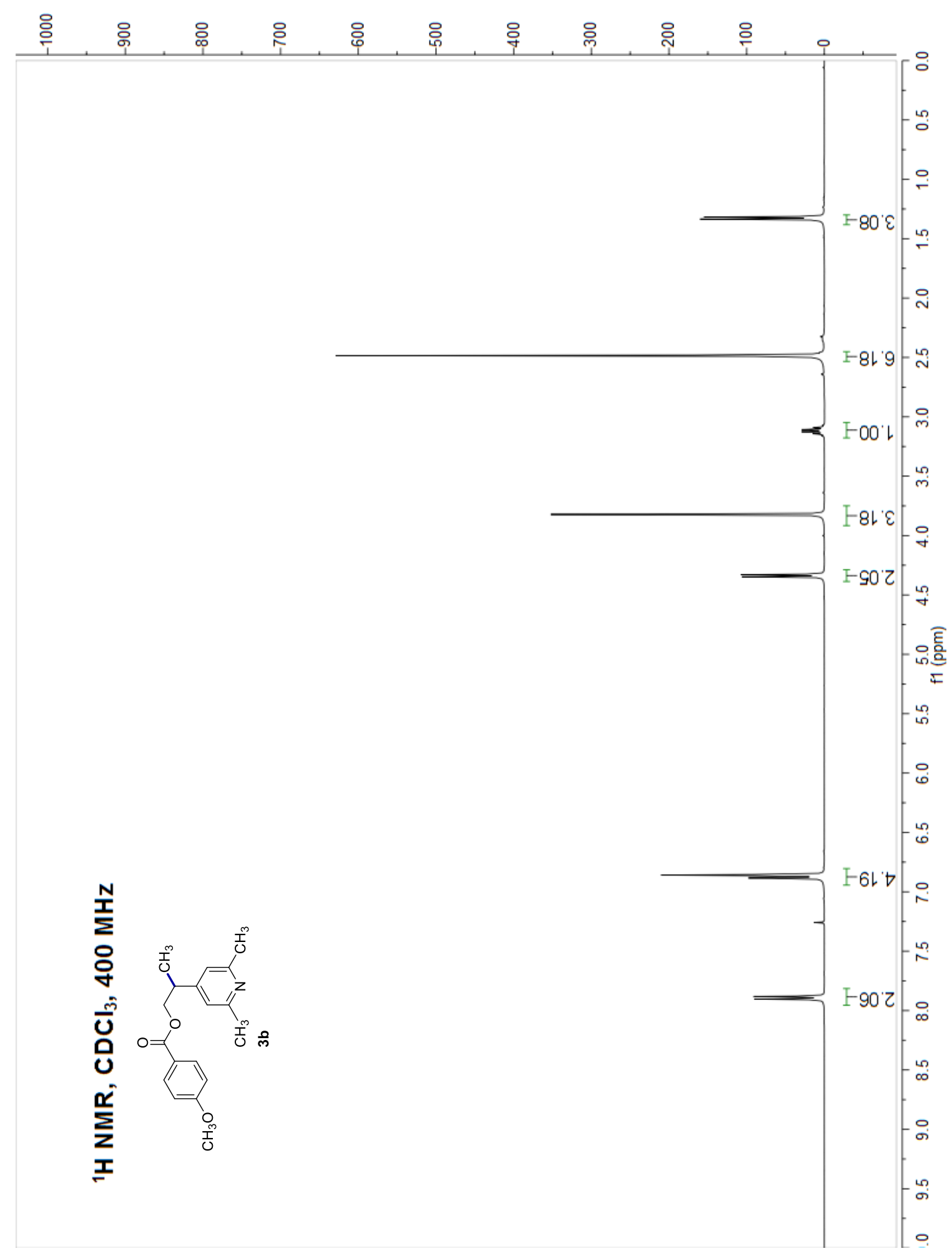




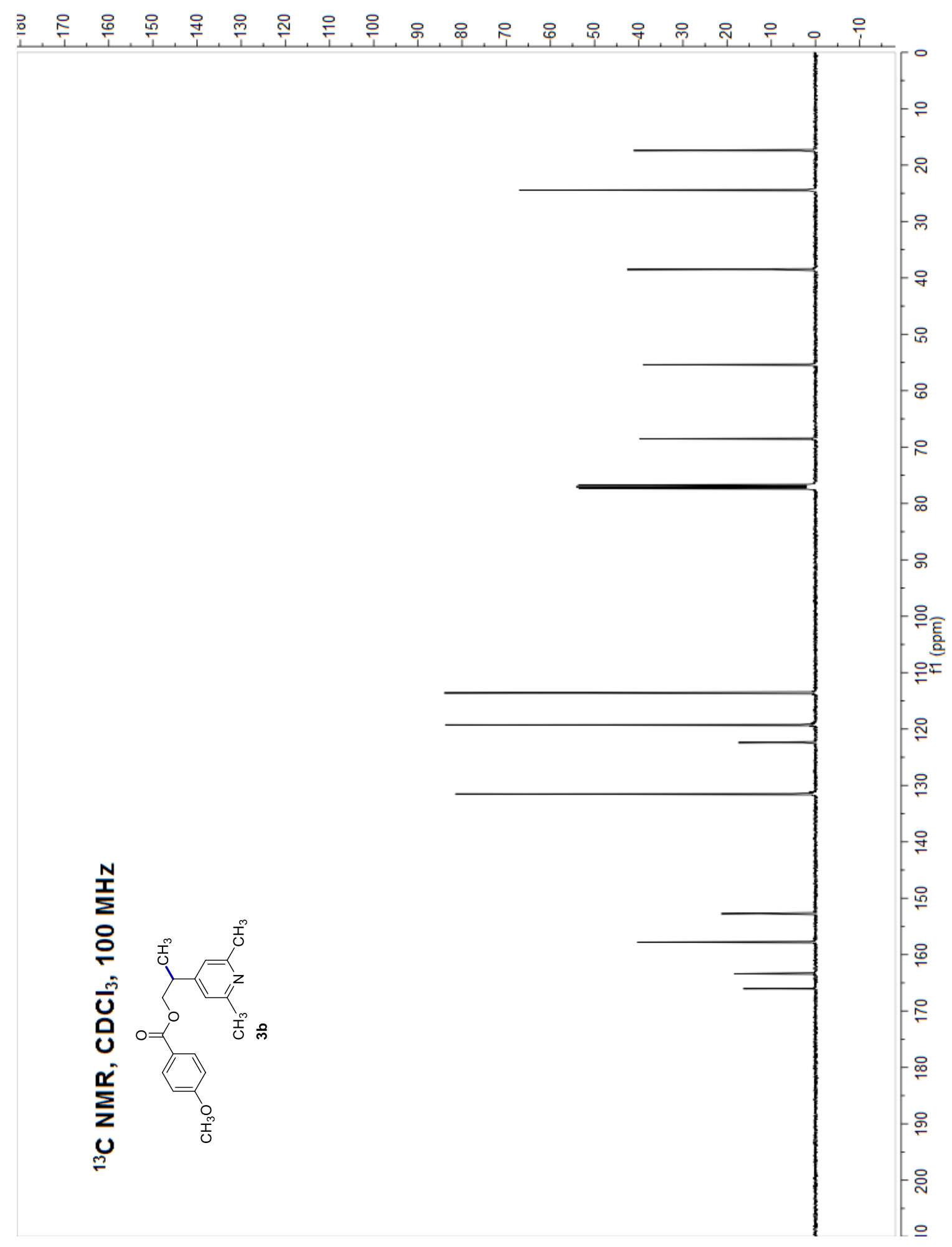




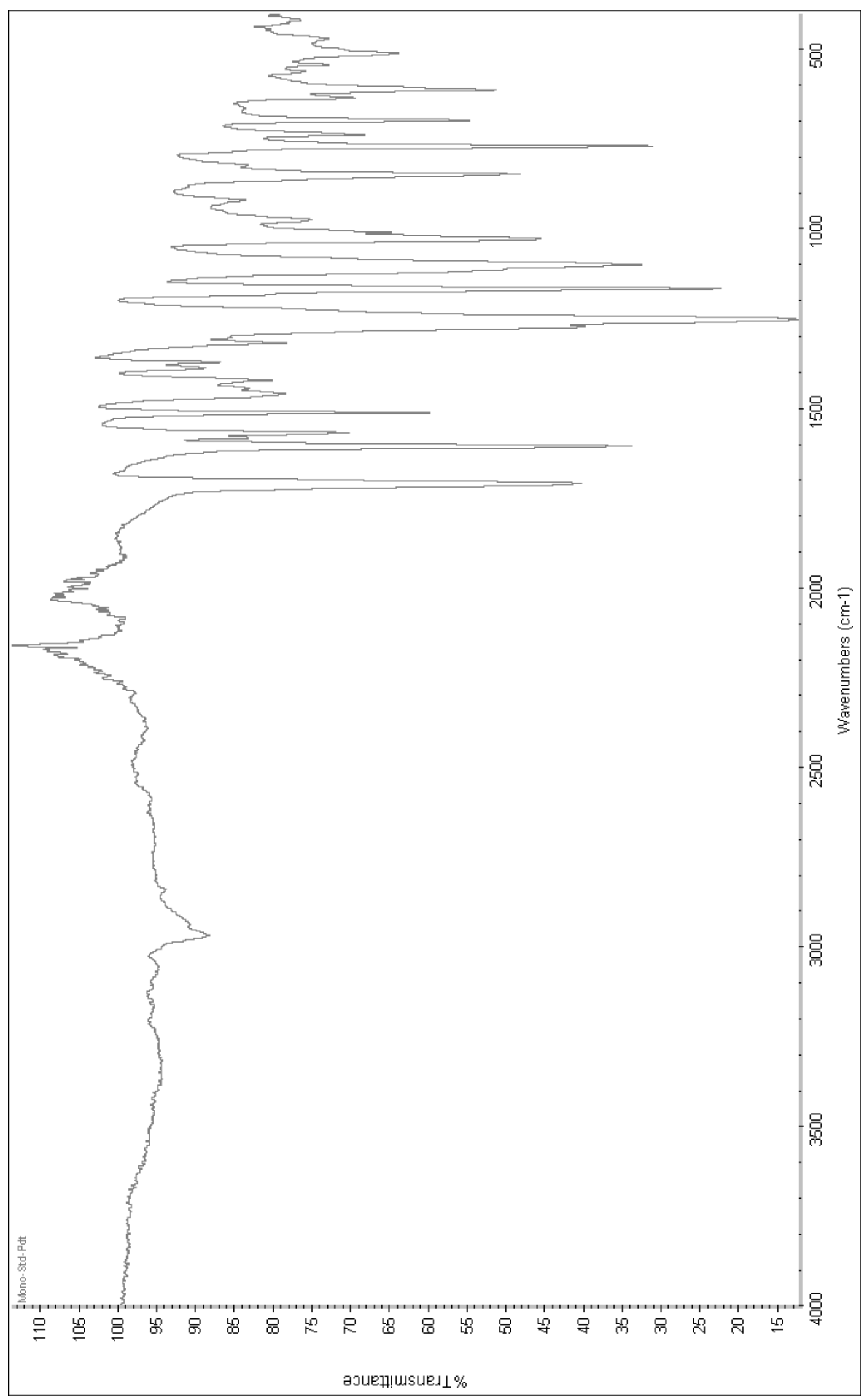




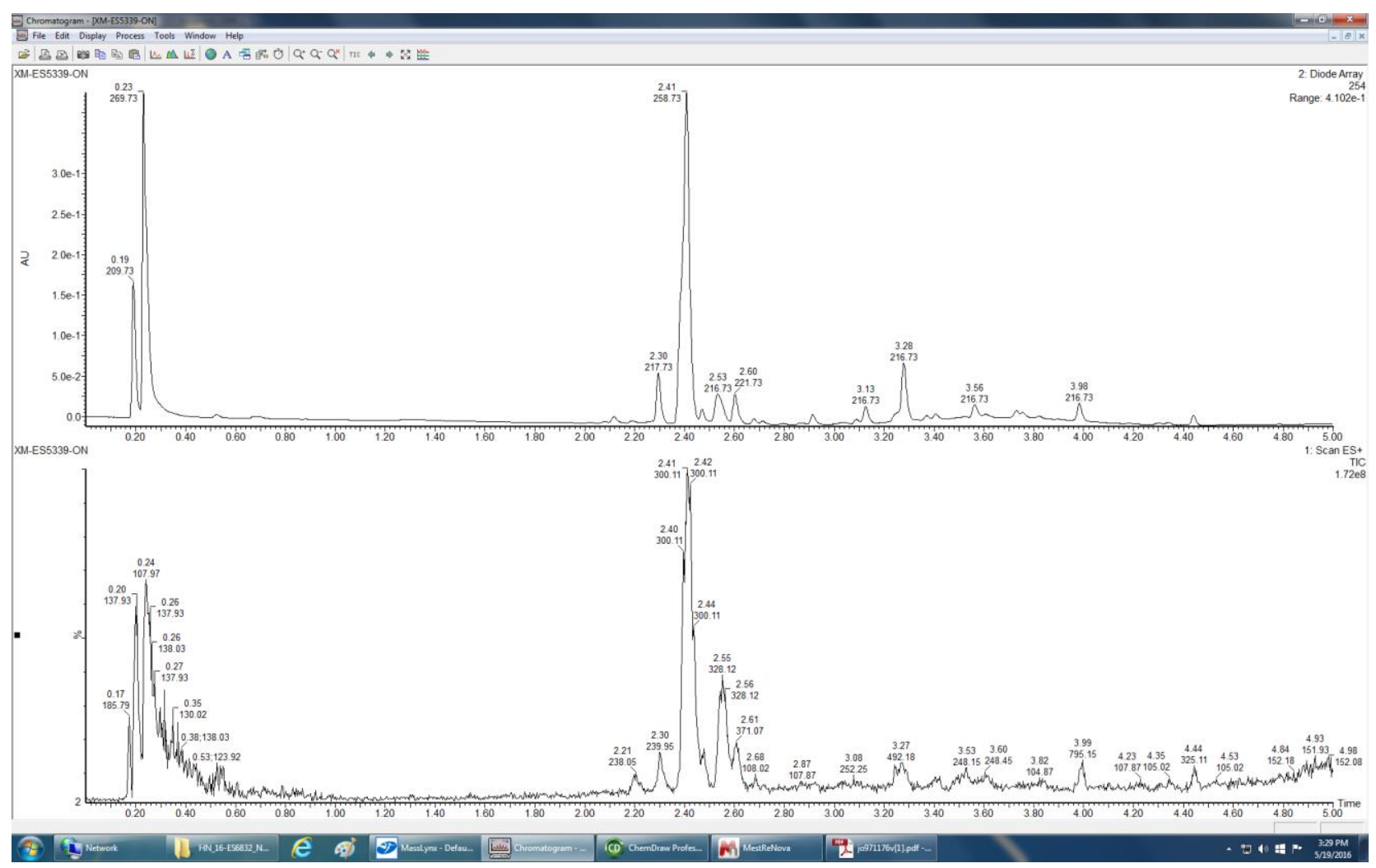




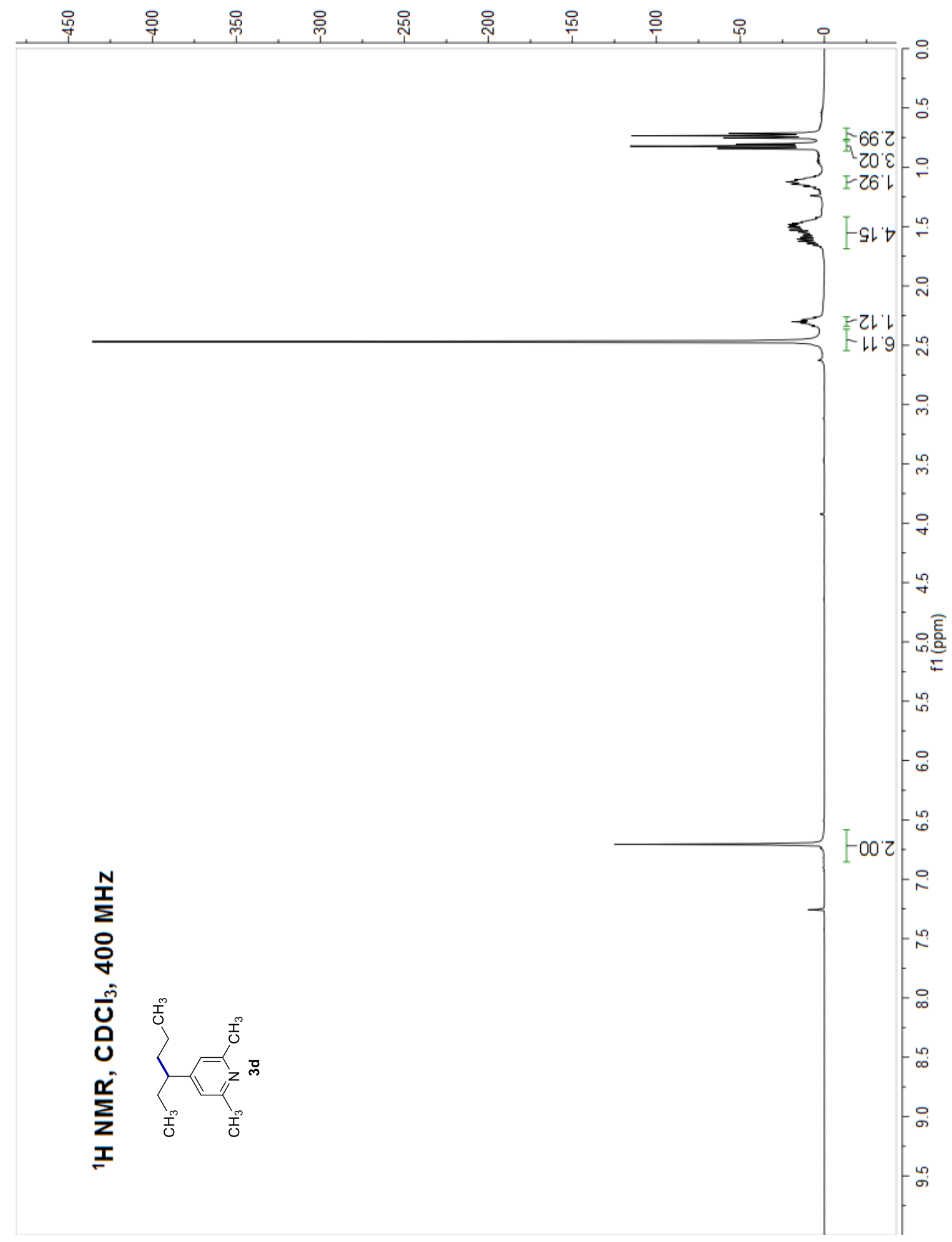




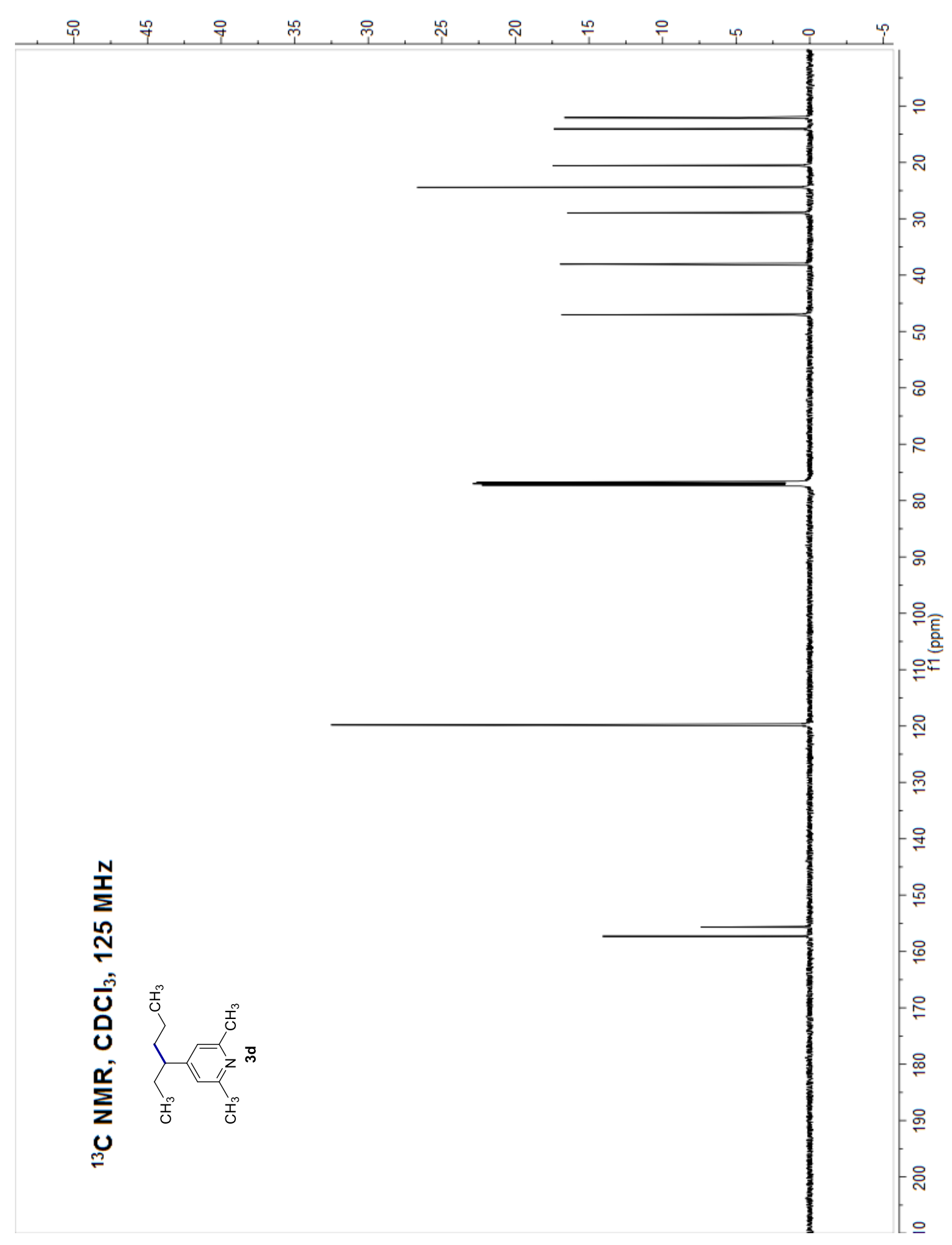




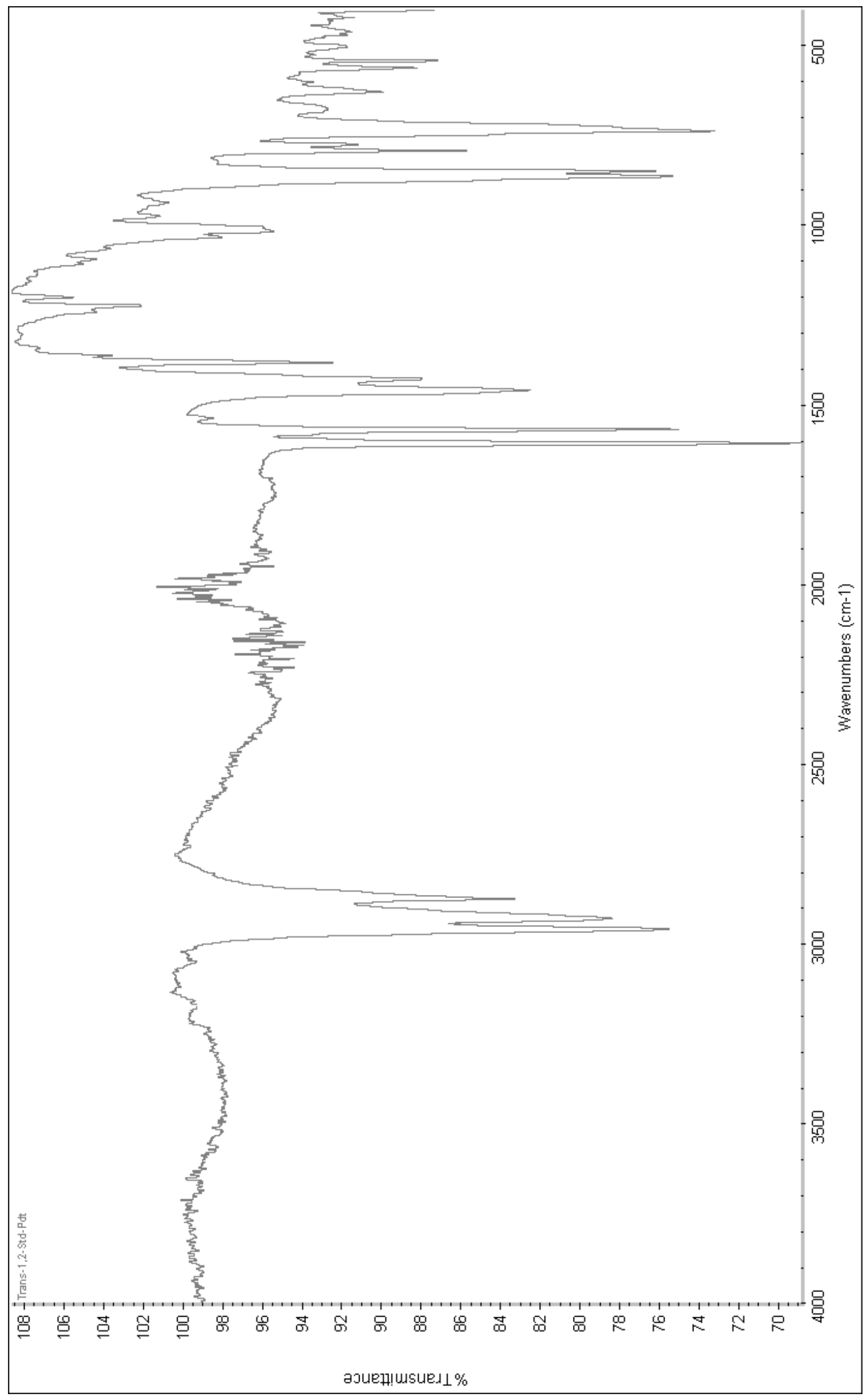

Ma and Herzon "Intermolecular hydropyridylation of unactivated alkenes" J. Am. Chem. Soc. 


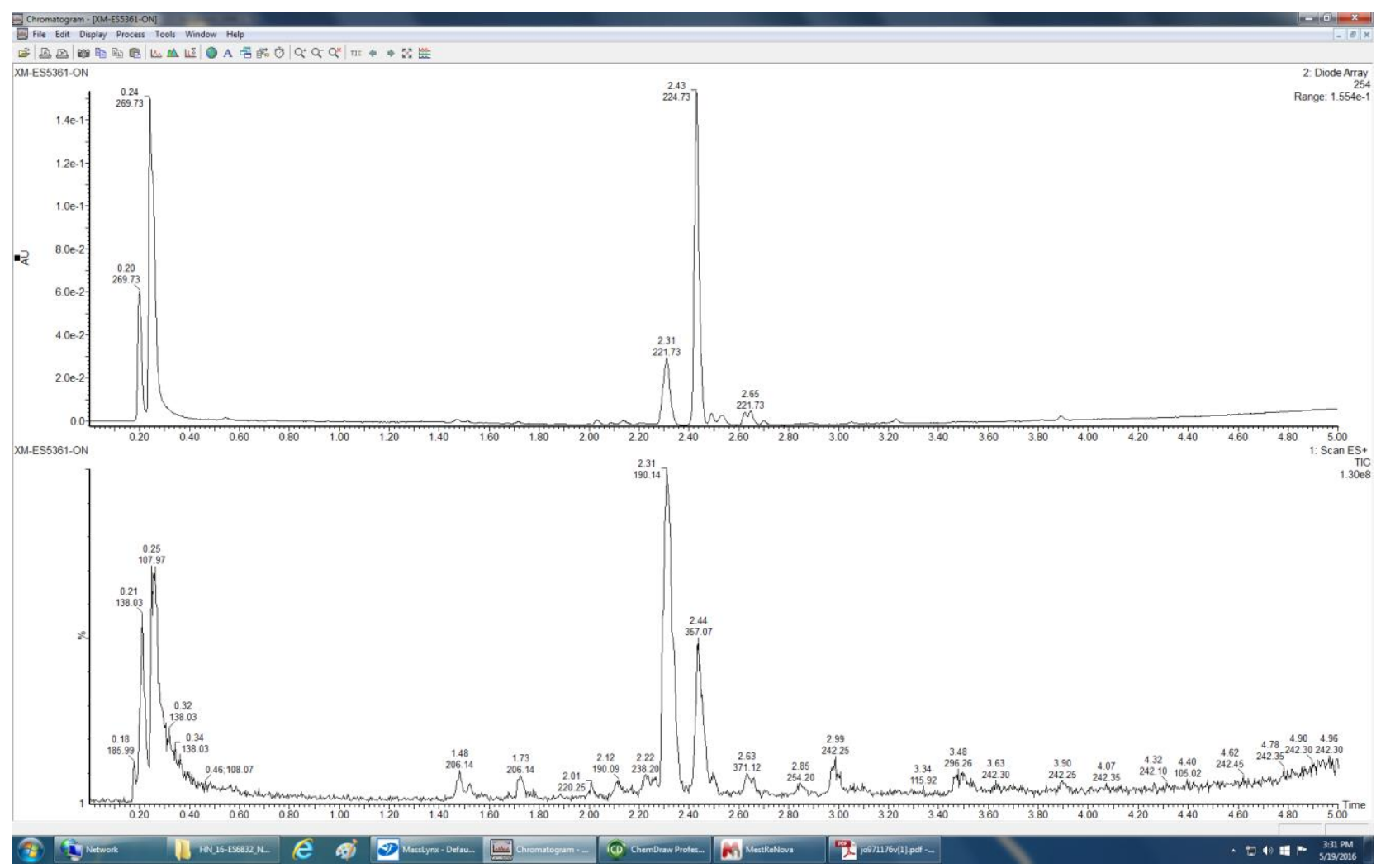




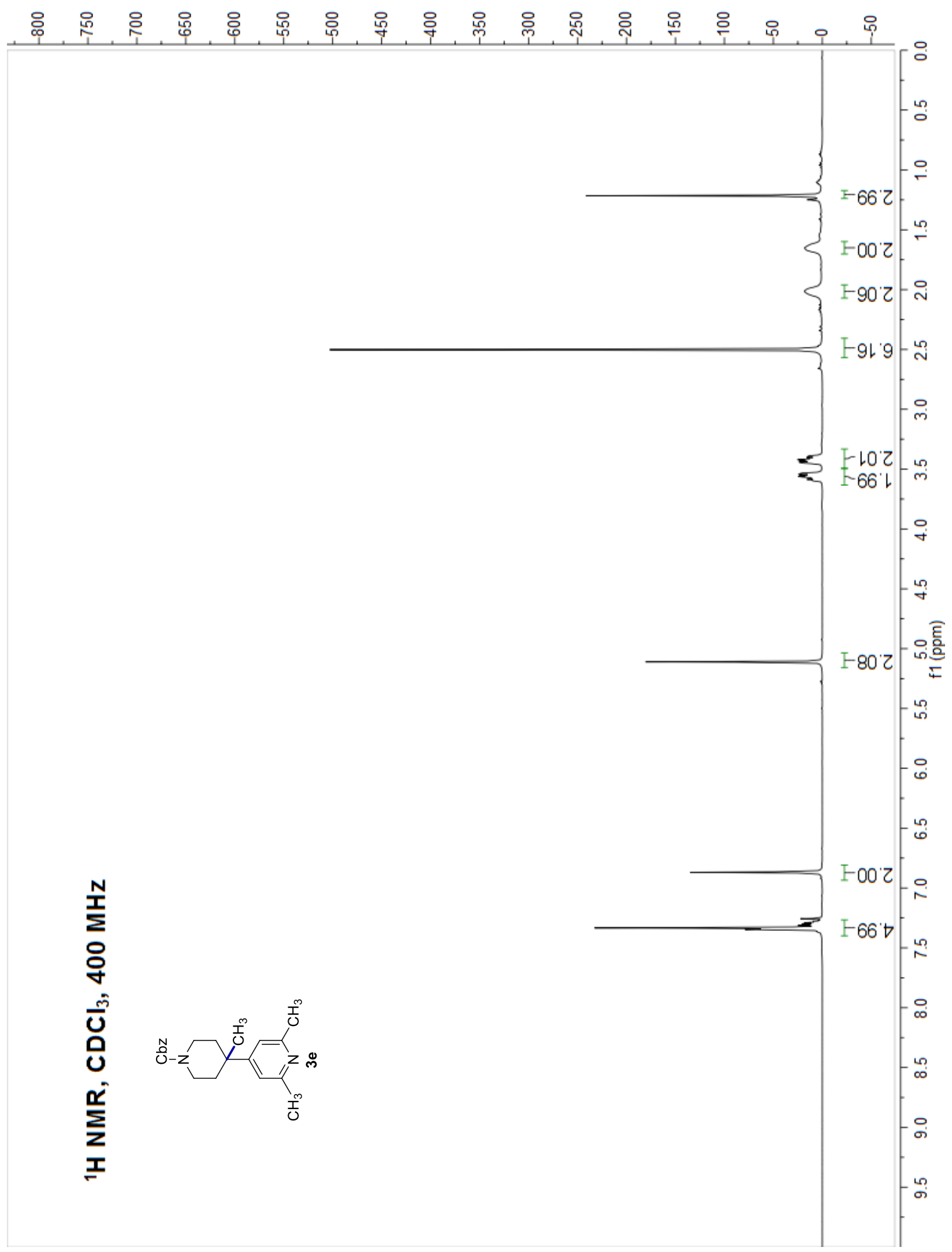




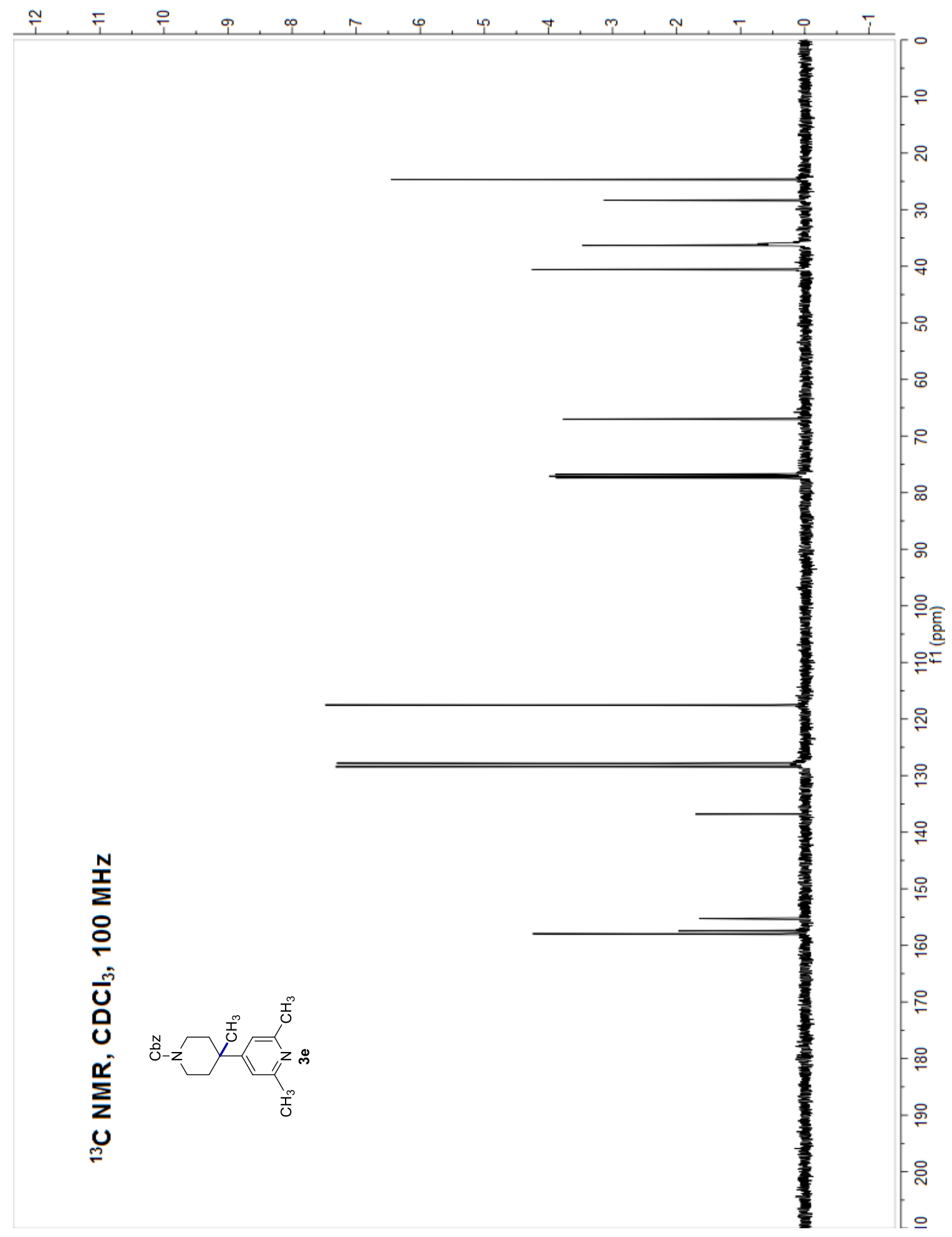




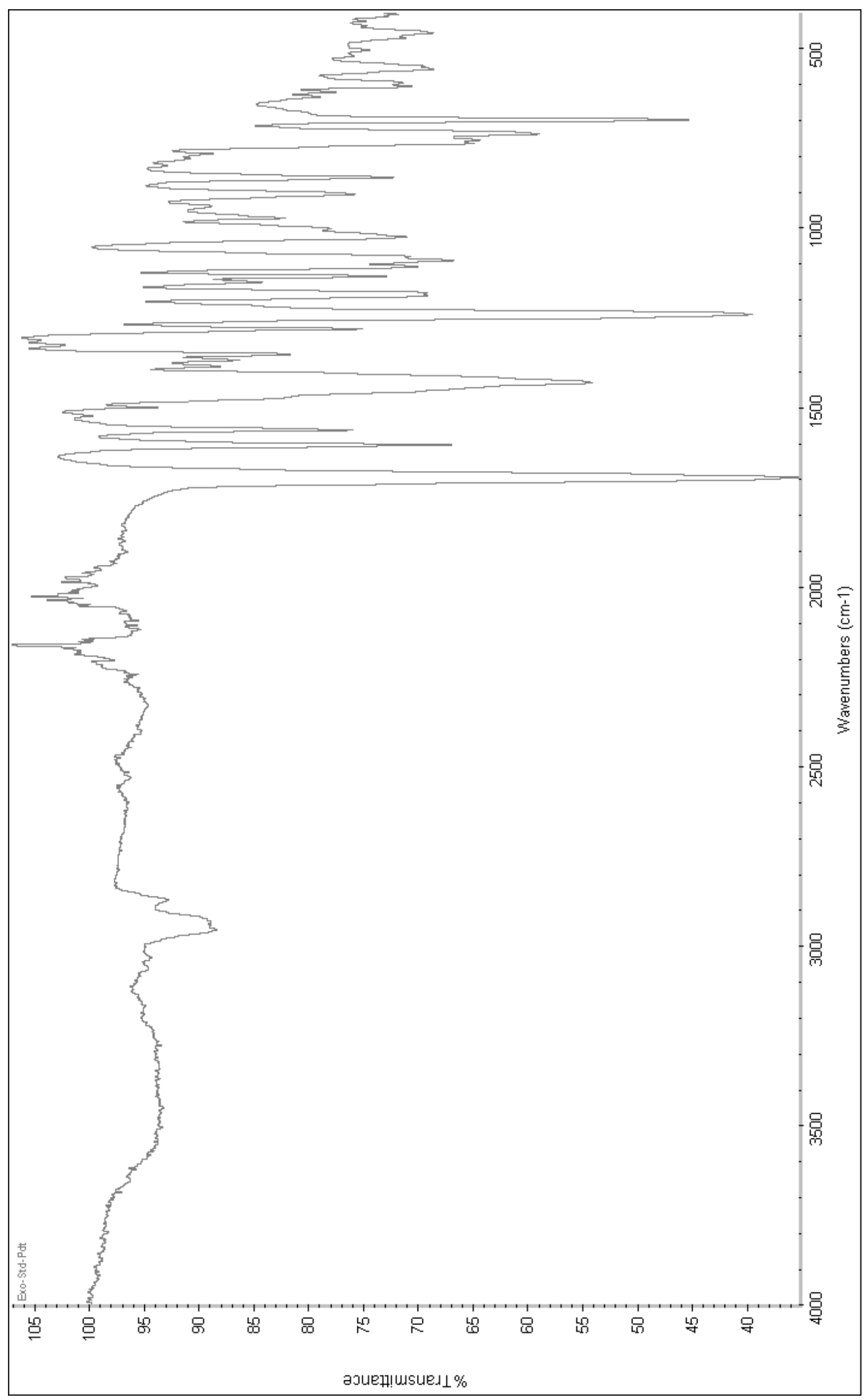




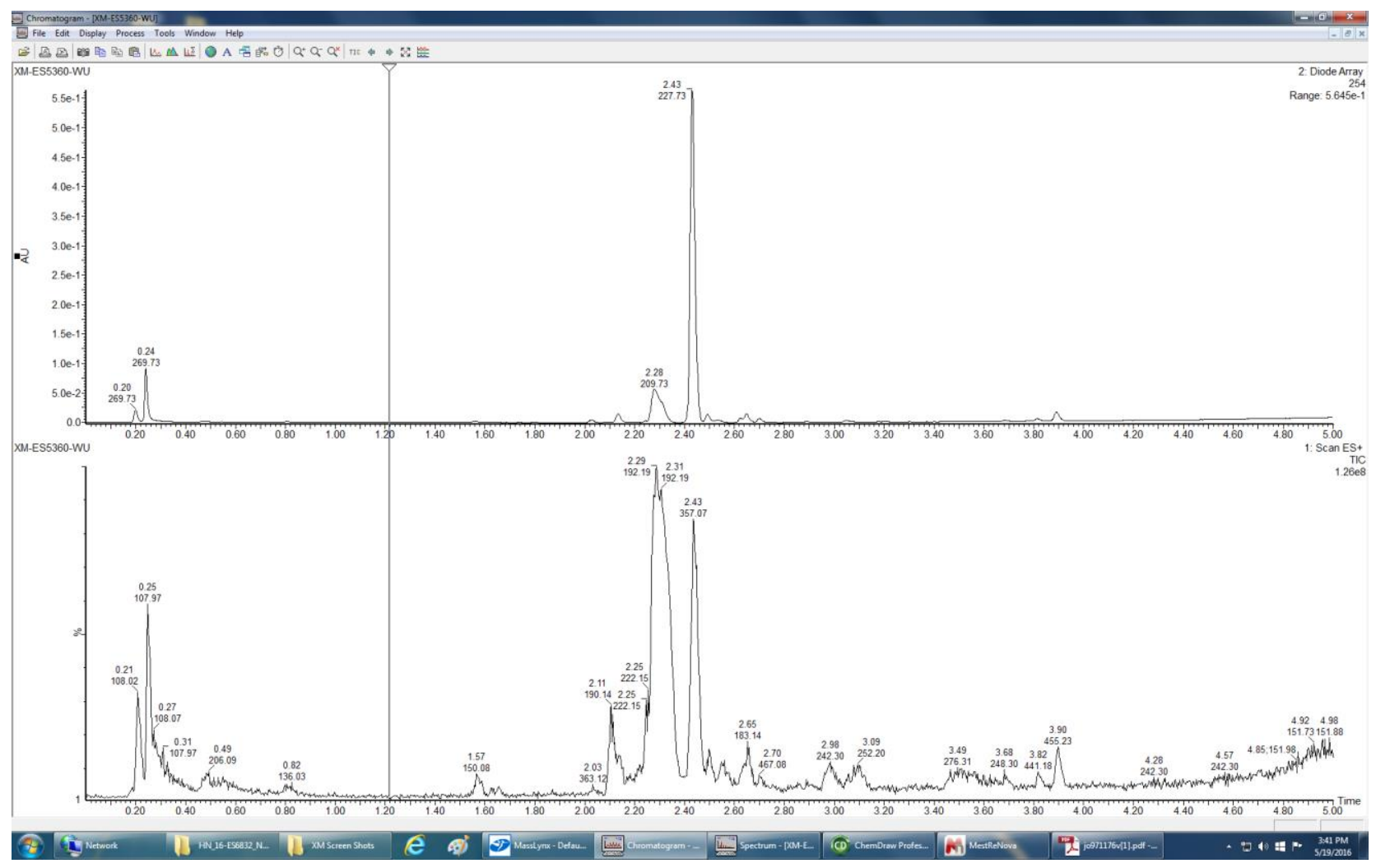




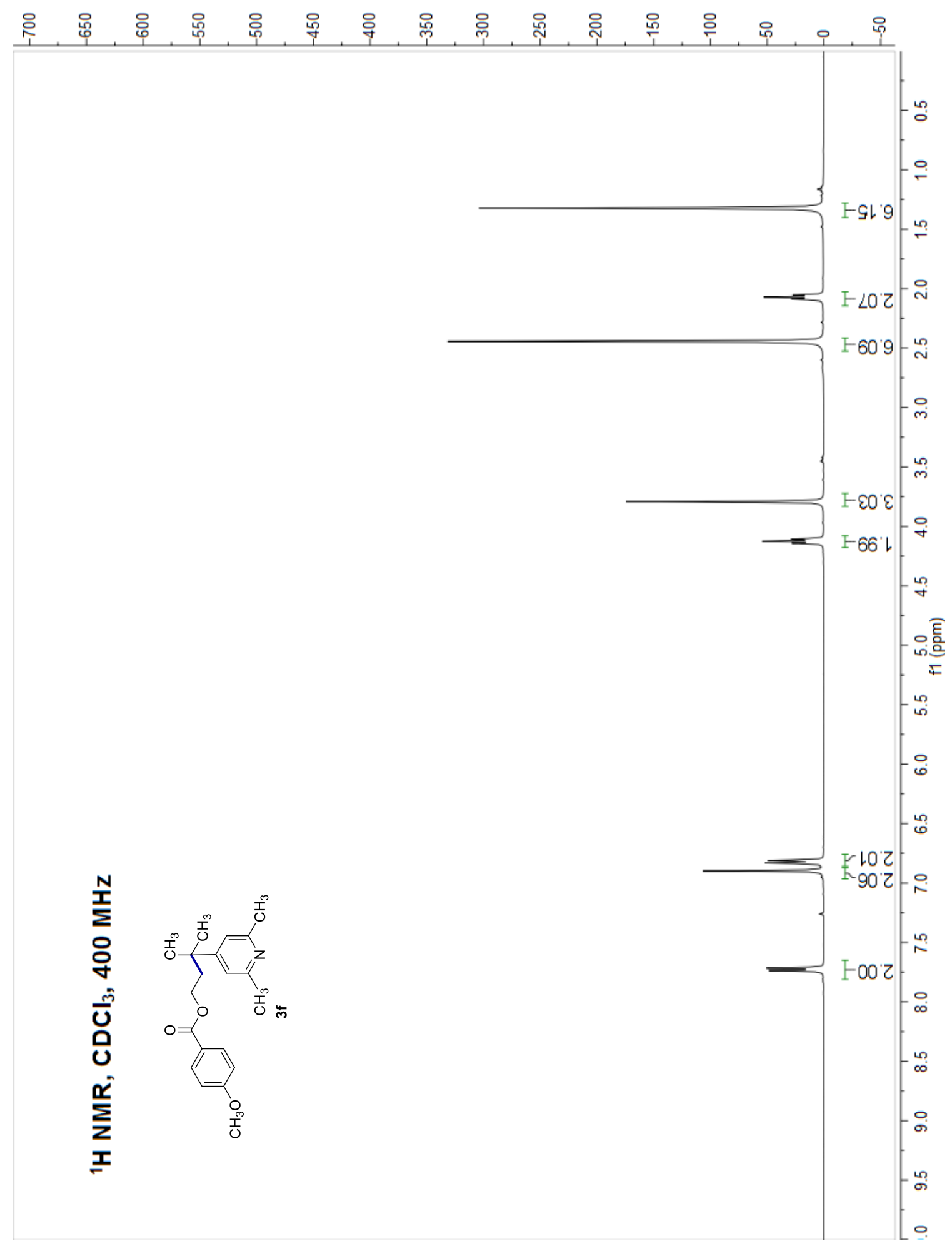




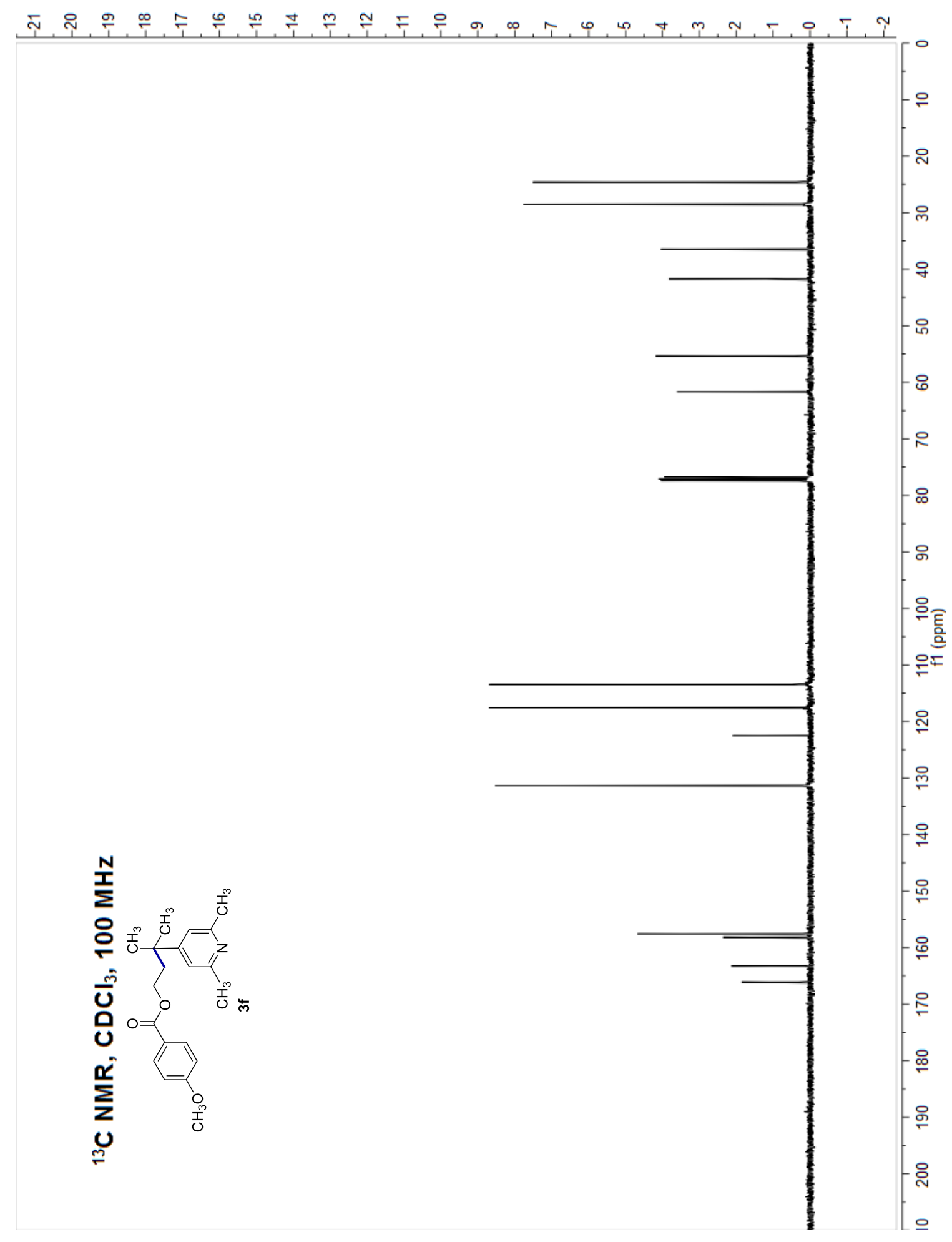




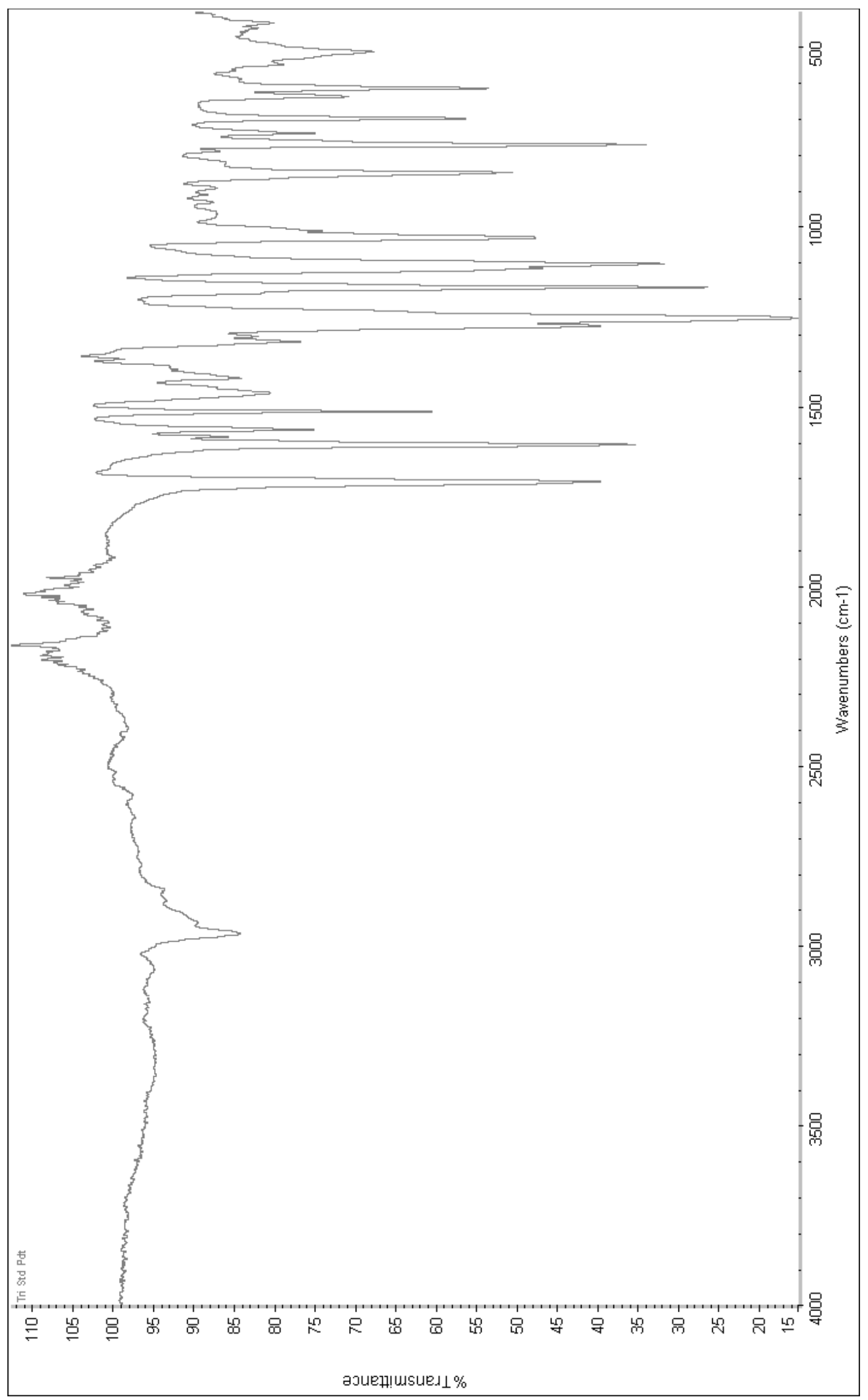

Ma and Herzon "Intermolecular hydropyridylation of unactivated alkenes" J. Am. Chem. Soc. 


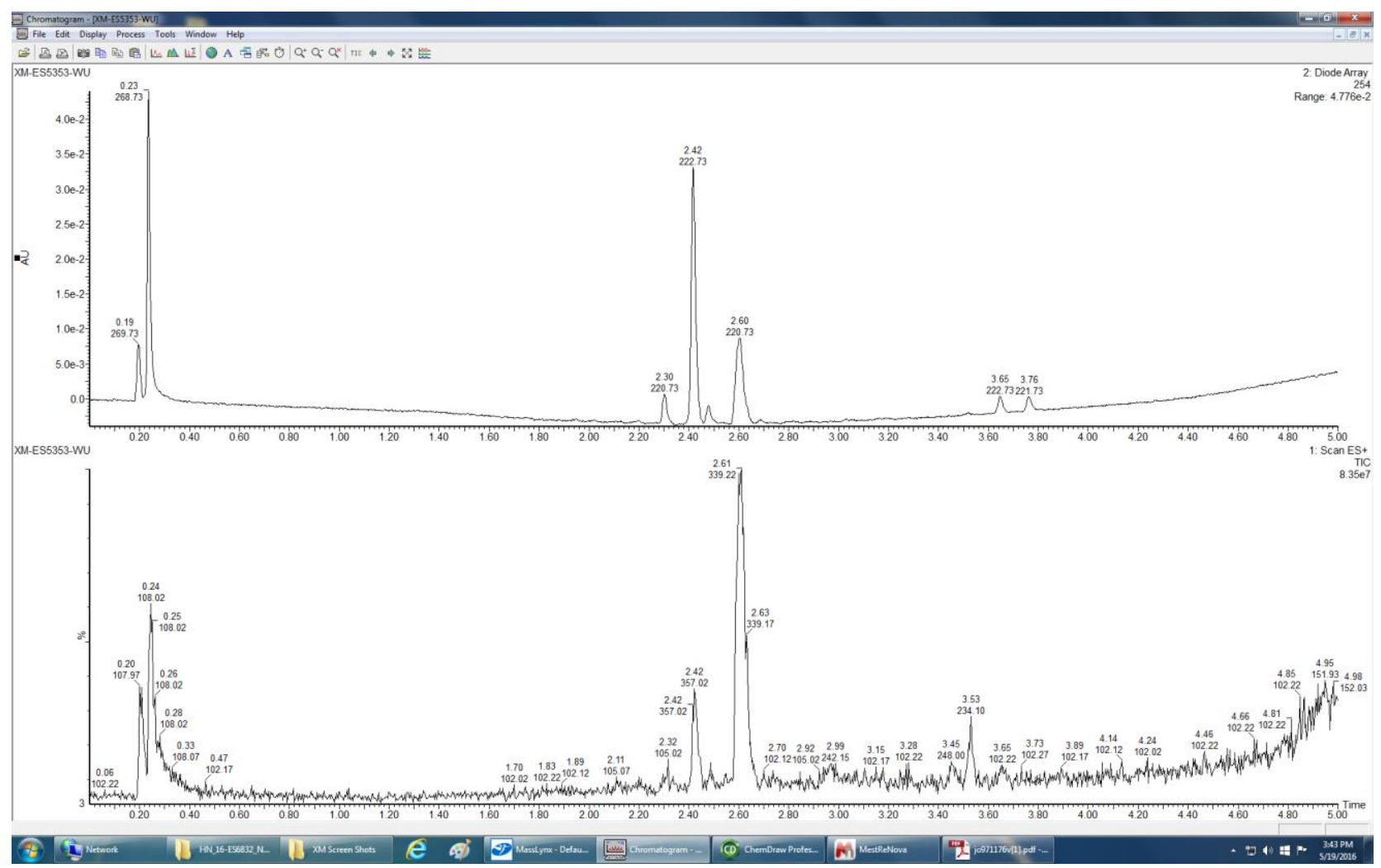




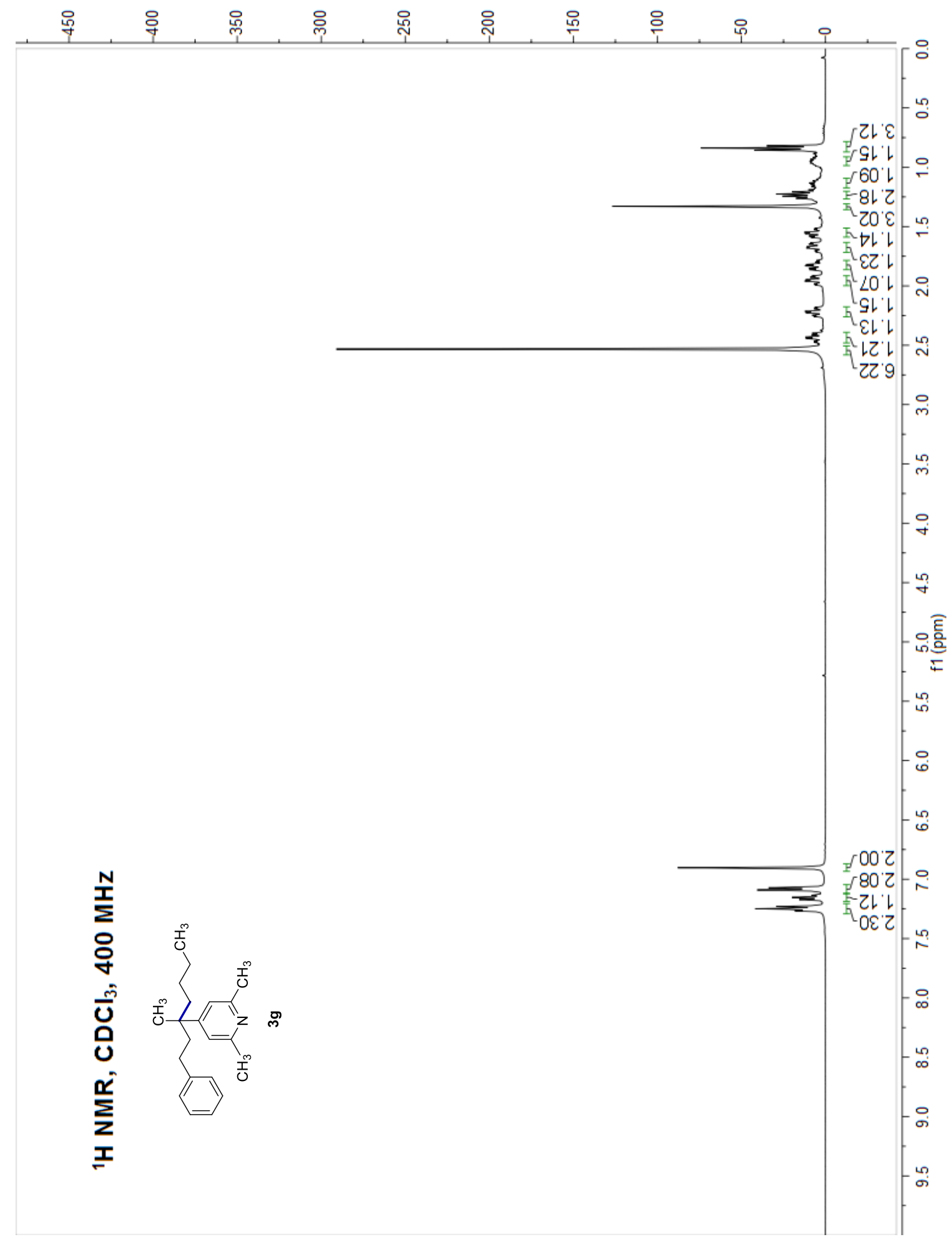




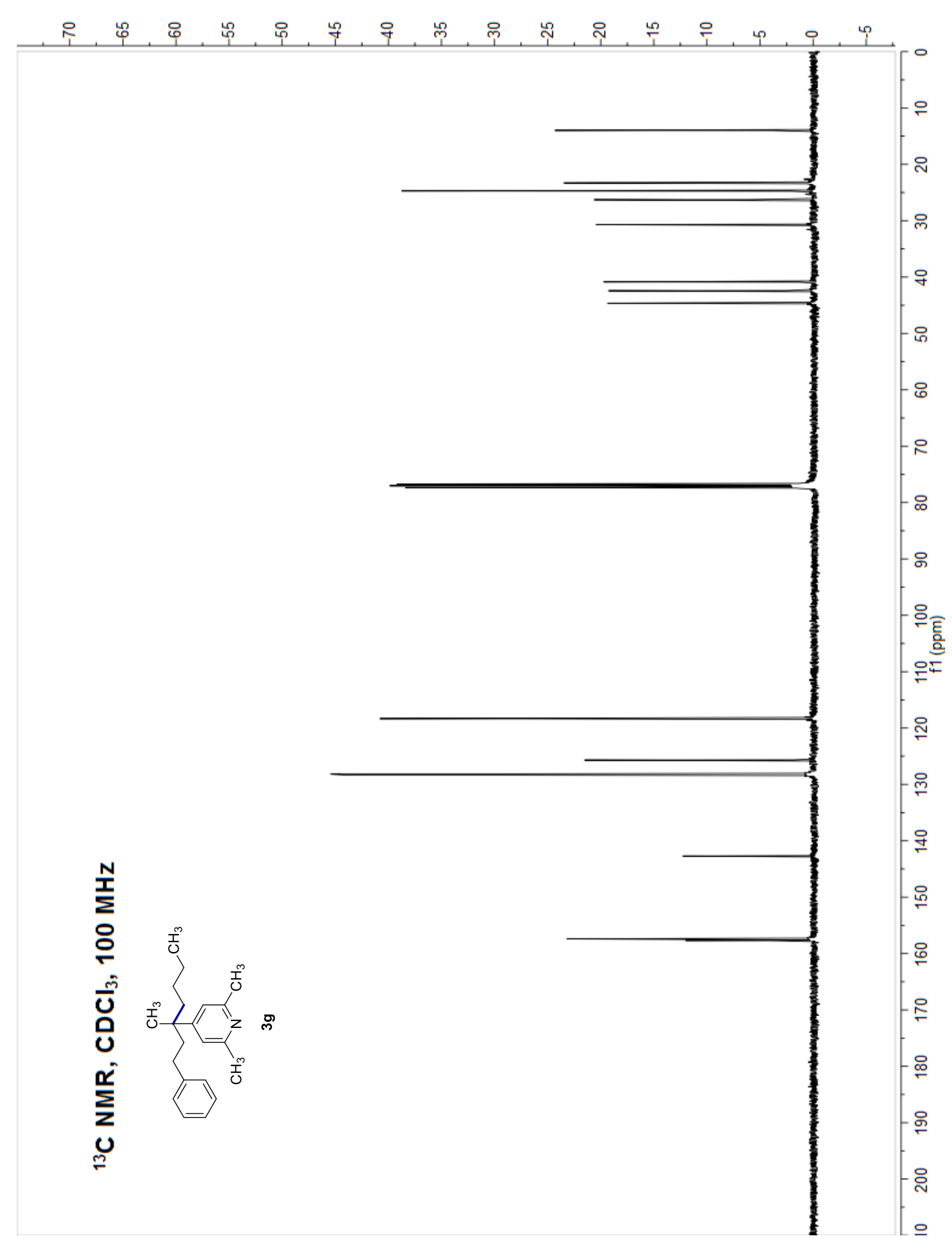




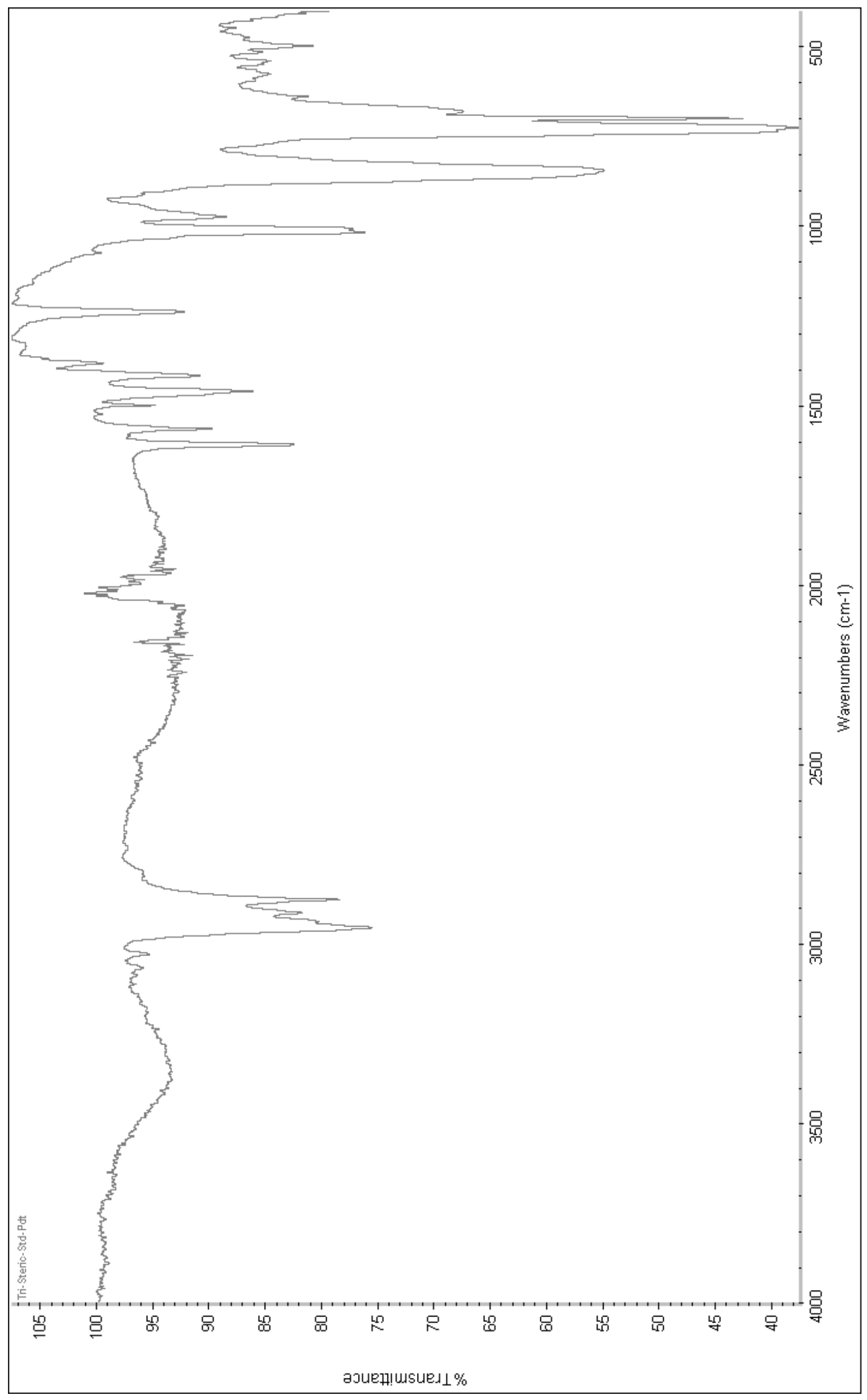

Ma and Herzon "Intermolecular hydropyridylation of unactivated alkenes" J. Am. Chem. Soc. 


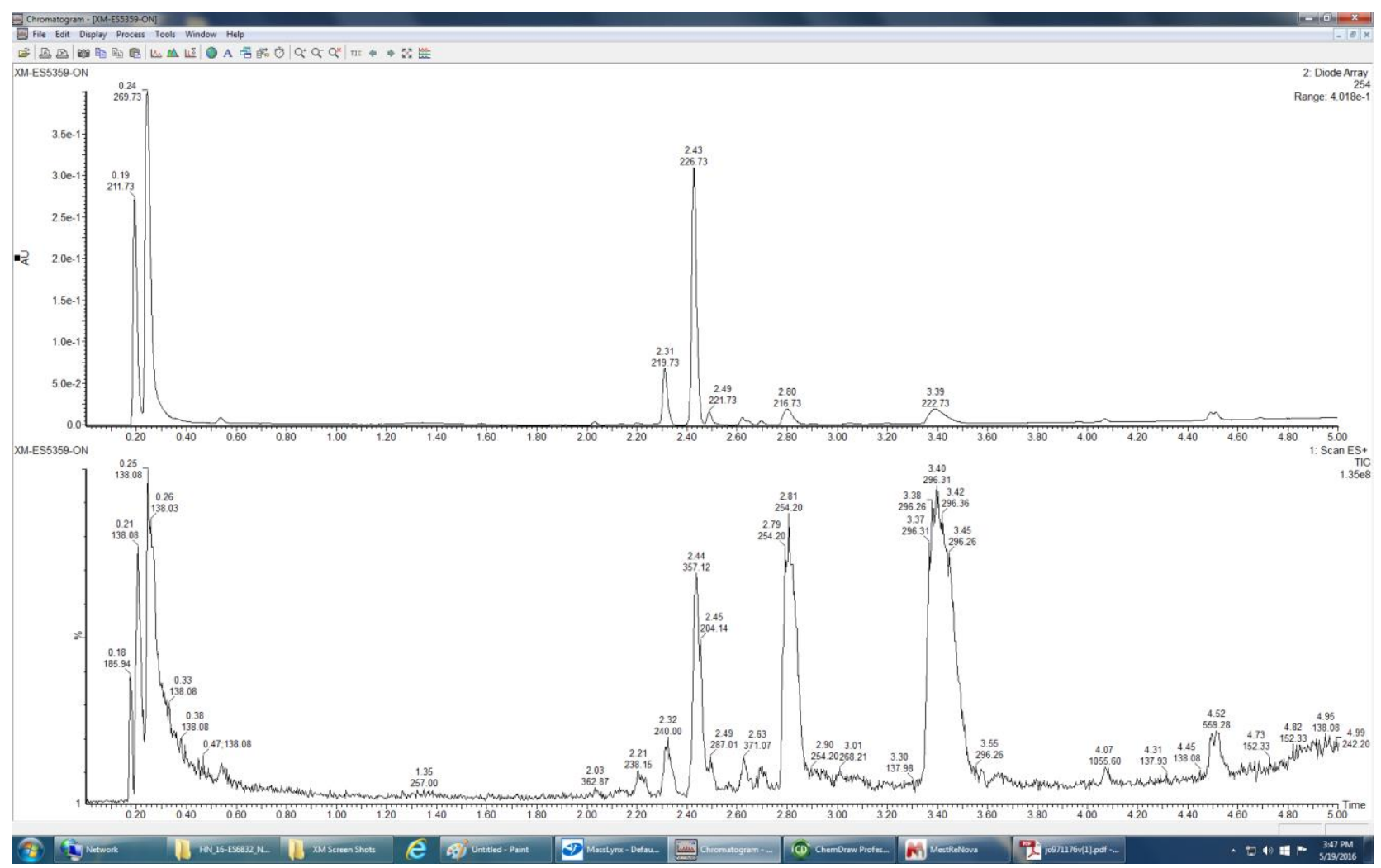




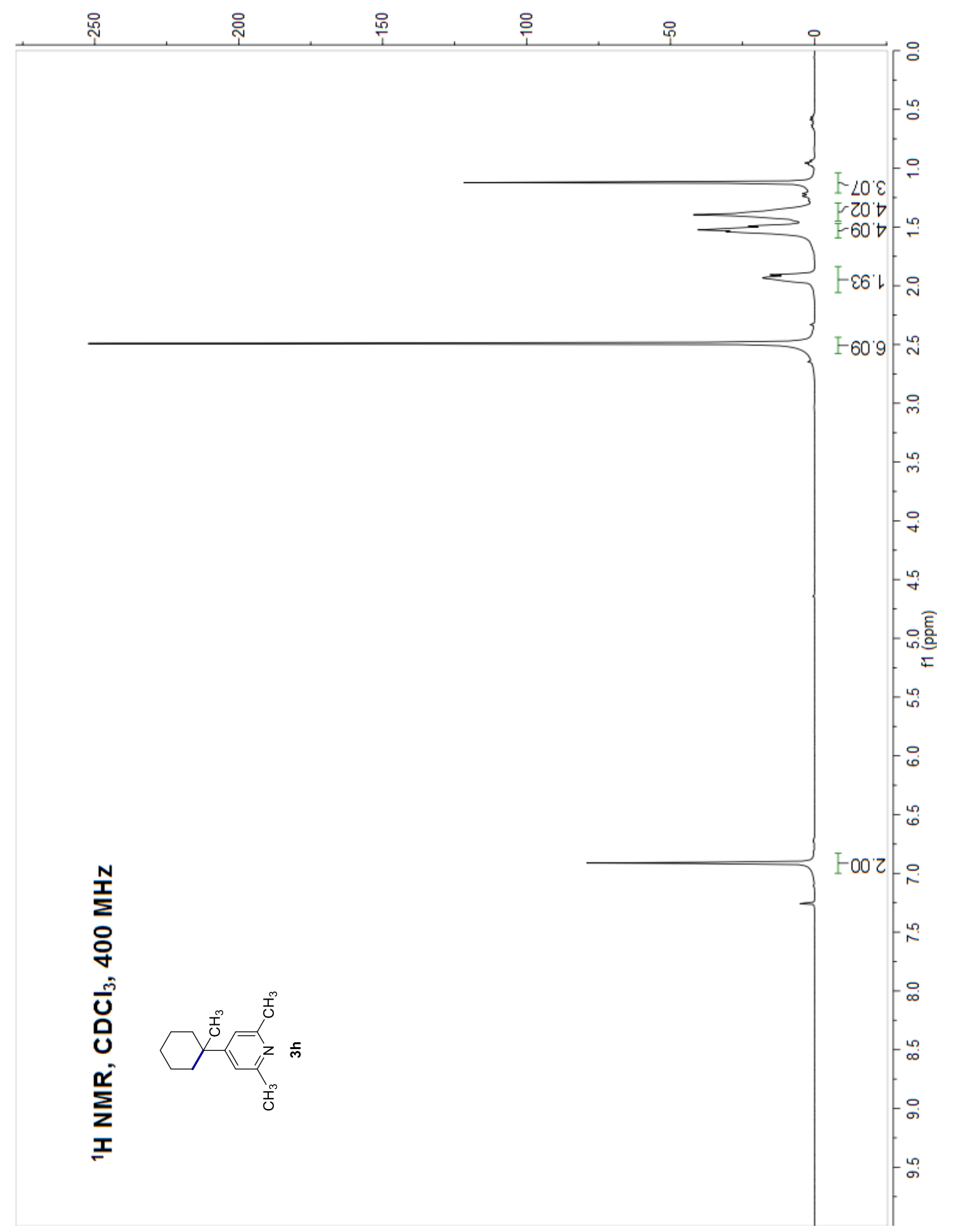




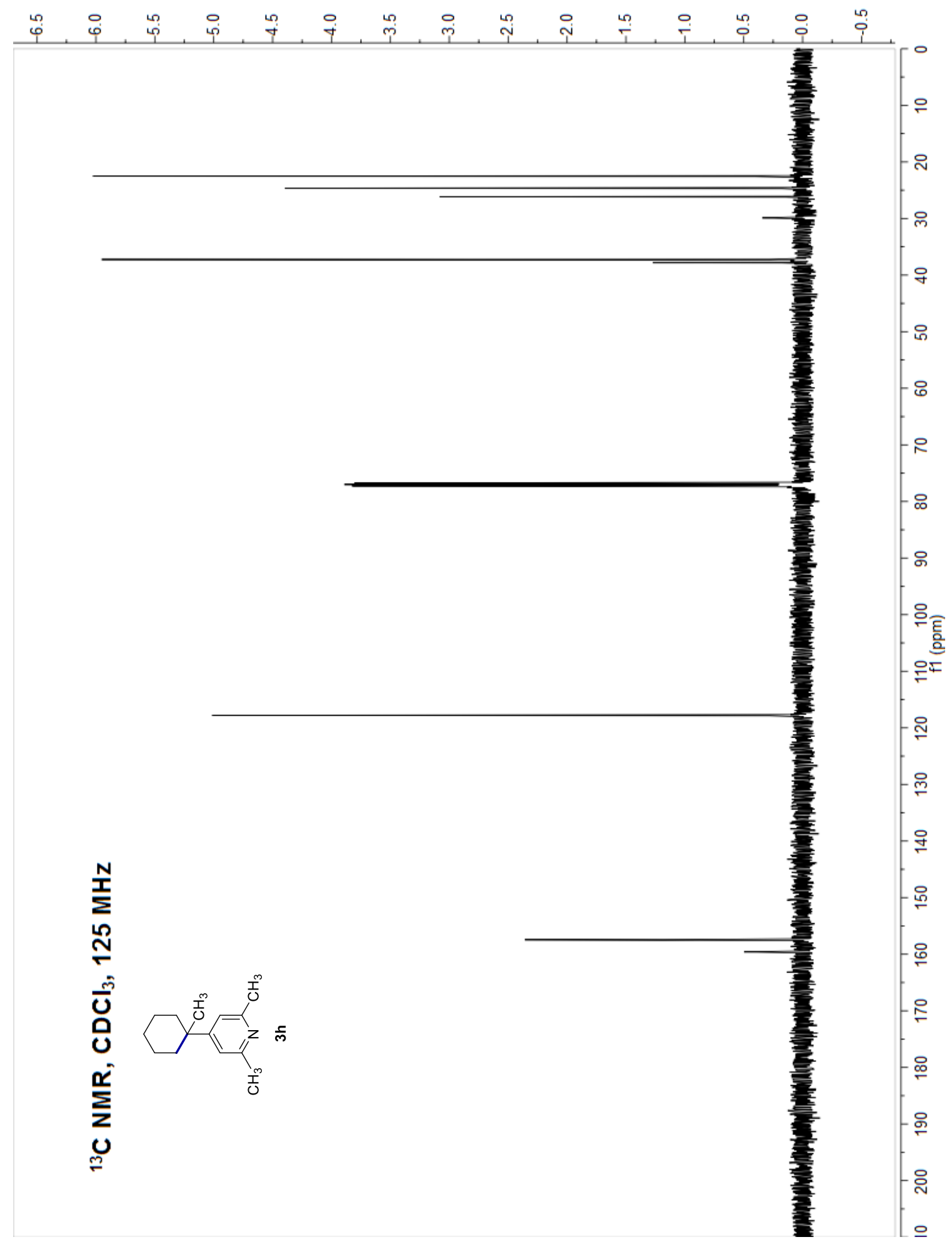




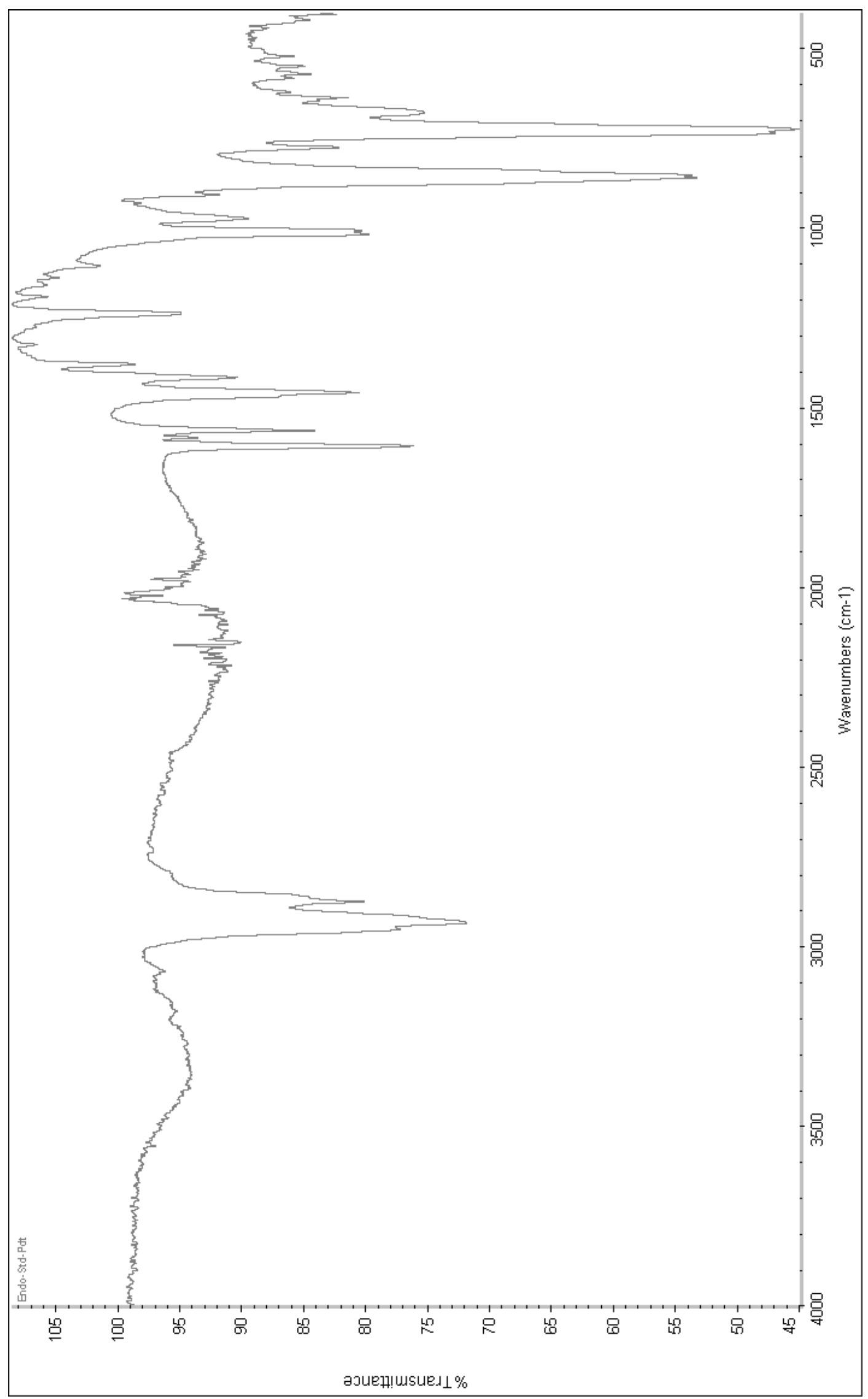

Ma and Herzon "Intermolecular hydropyridylation of unactivated alkenes" J. Am. Chem. Soc. 


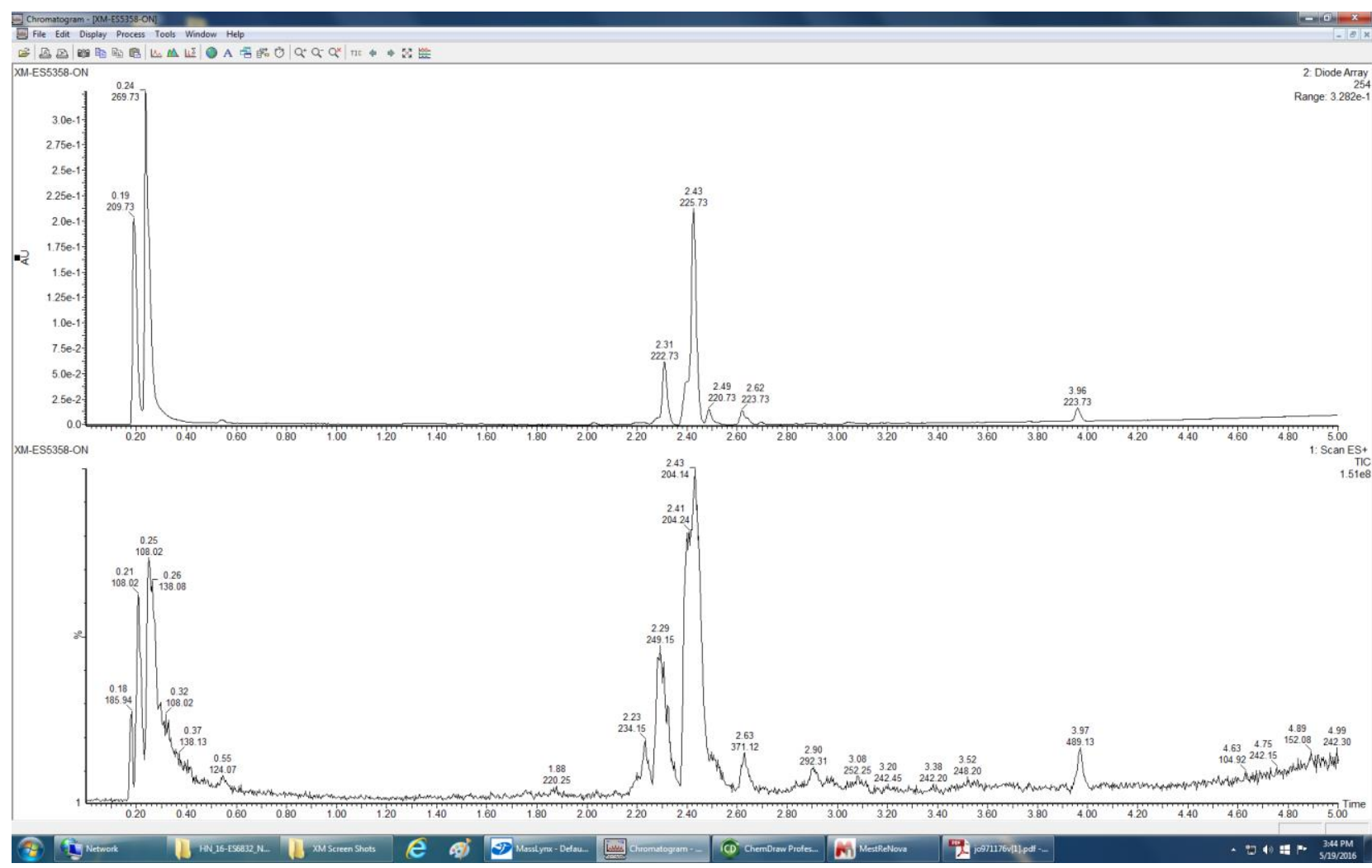




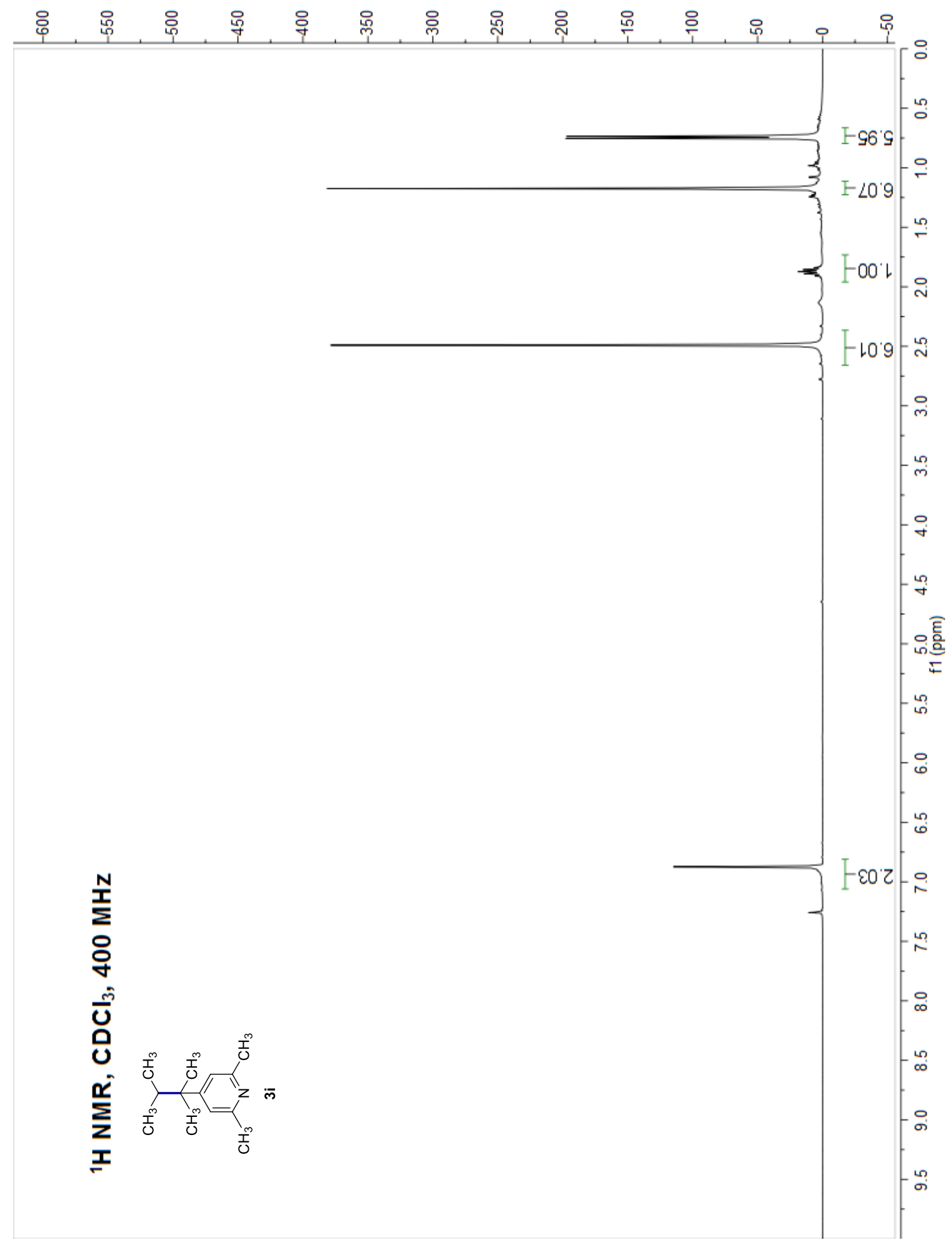




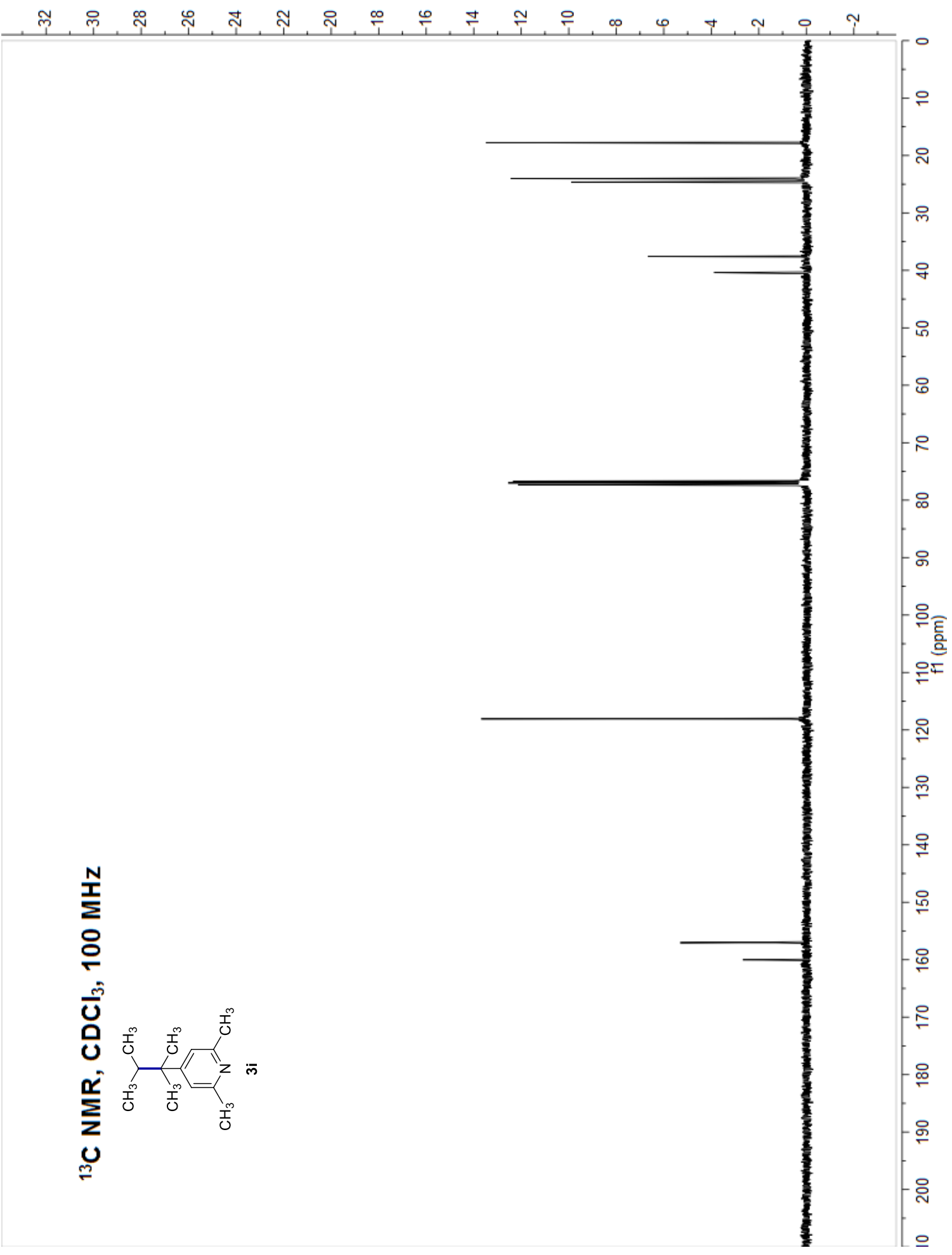




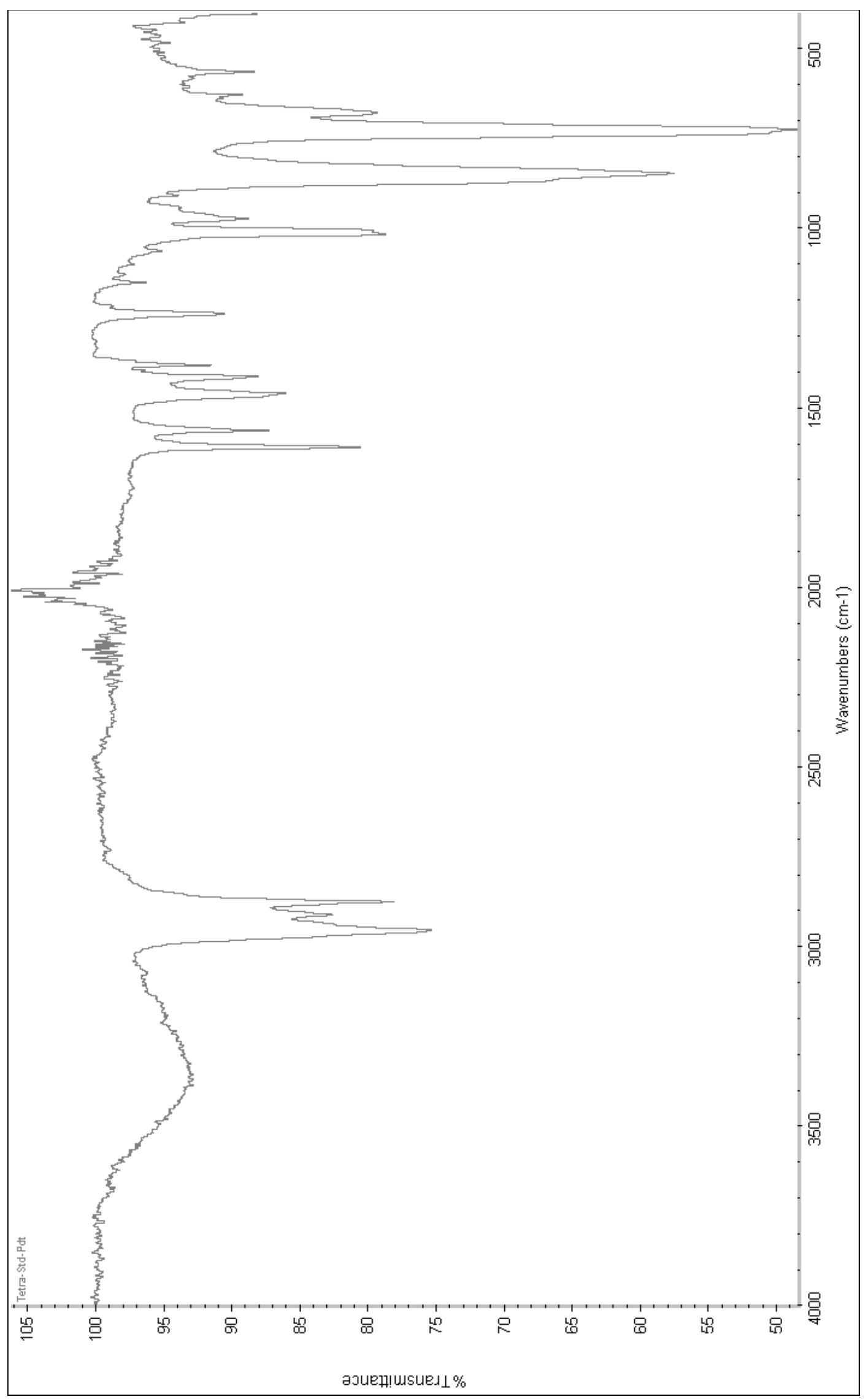

Ma and Herzon "Intermolecular hydropyridylation of unactivated alkenes" J. Am. Chem. Soc. 


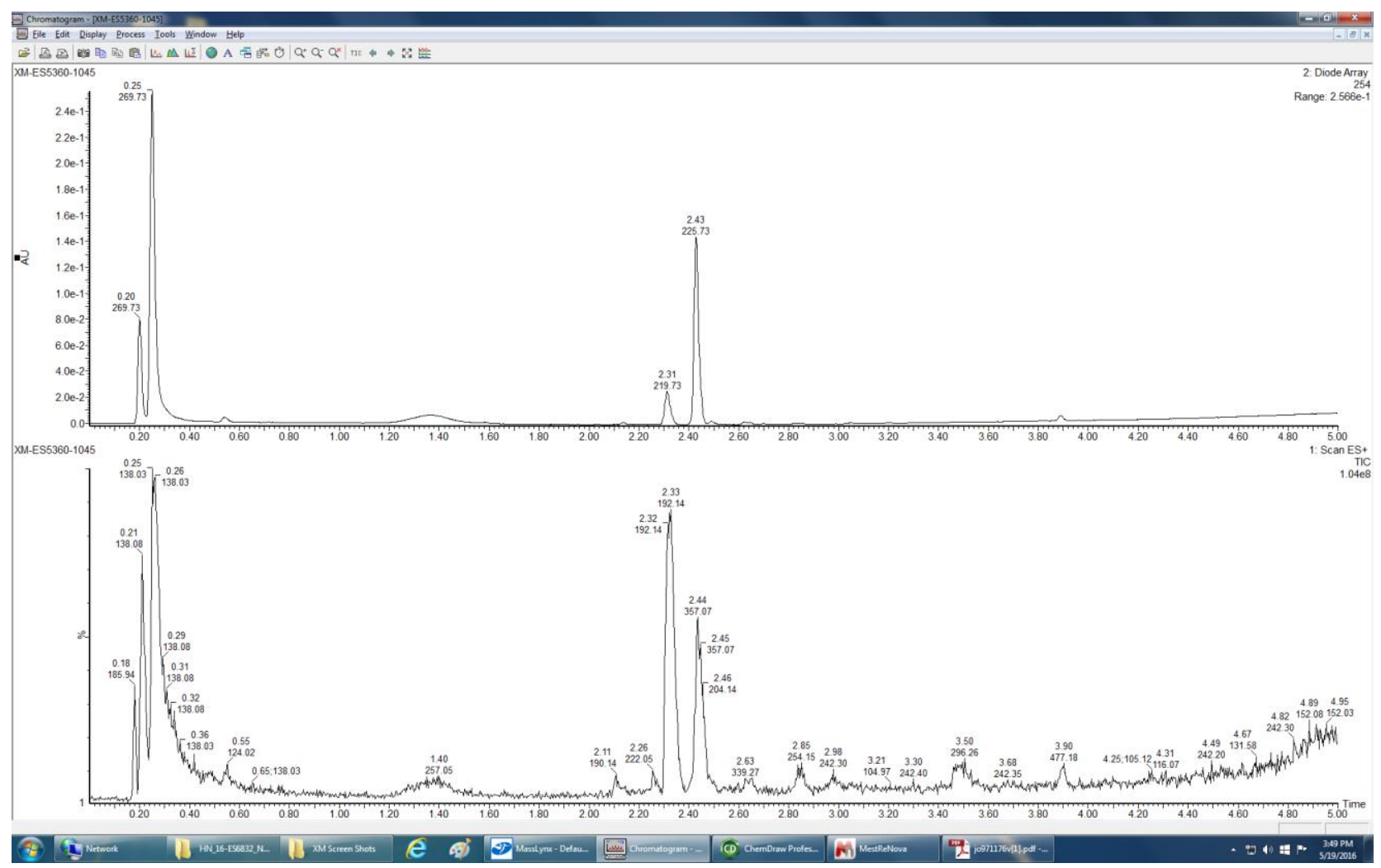




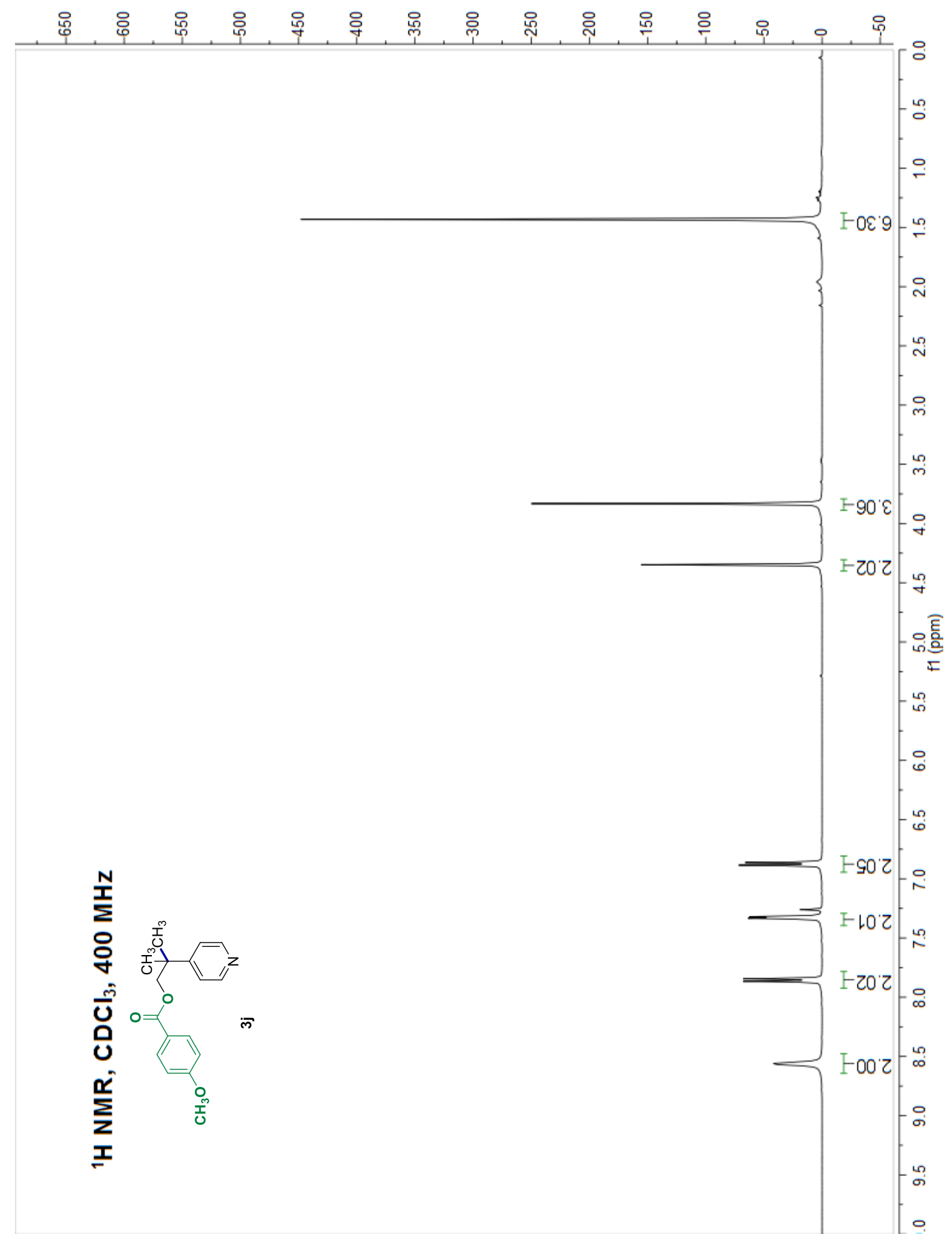




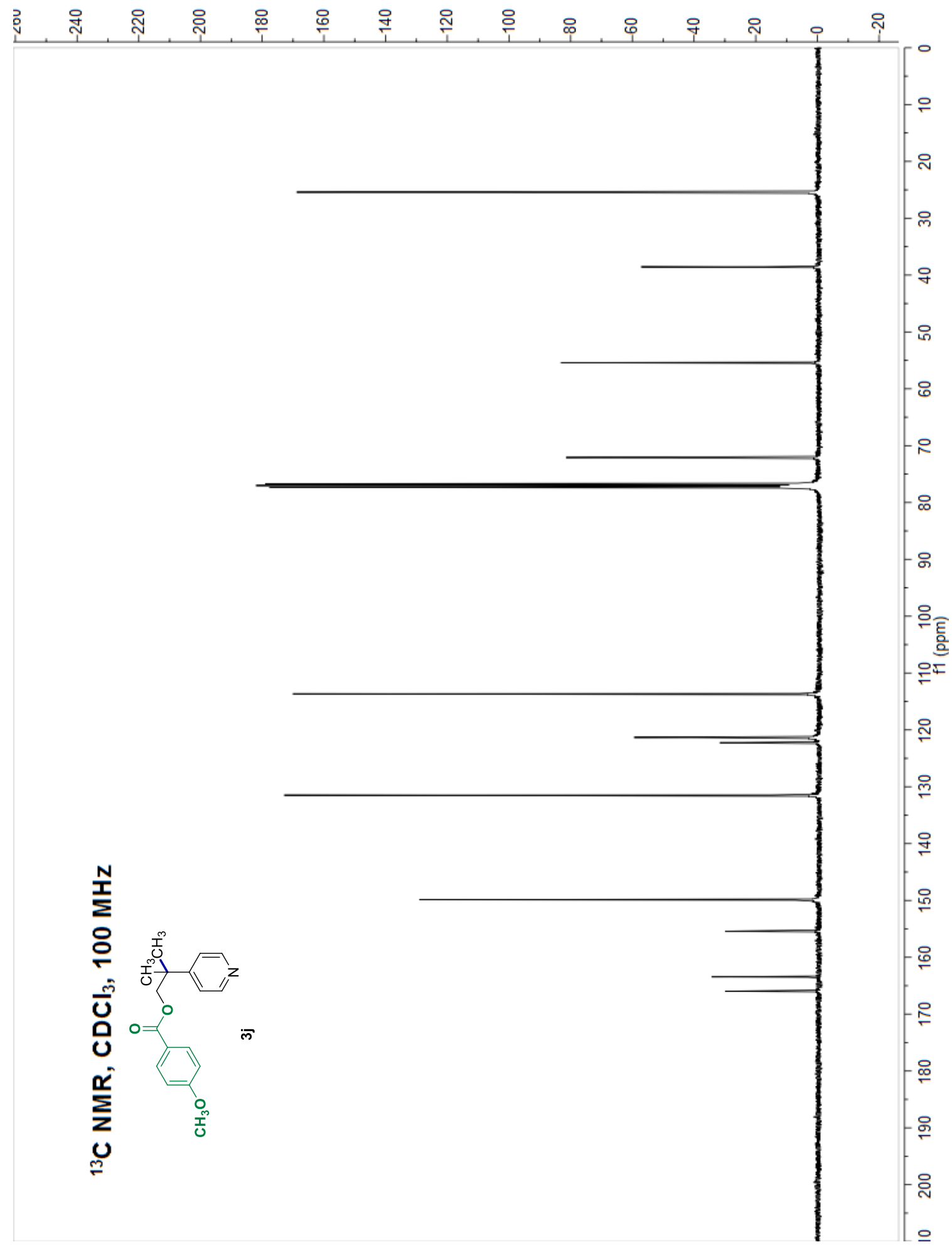




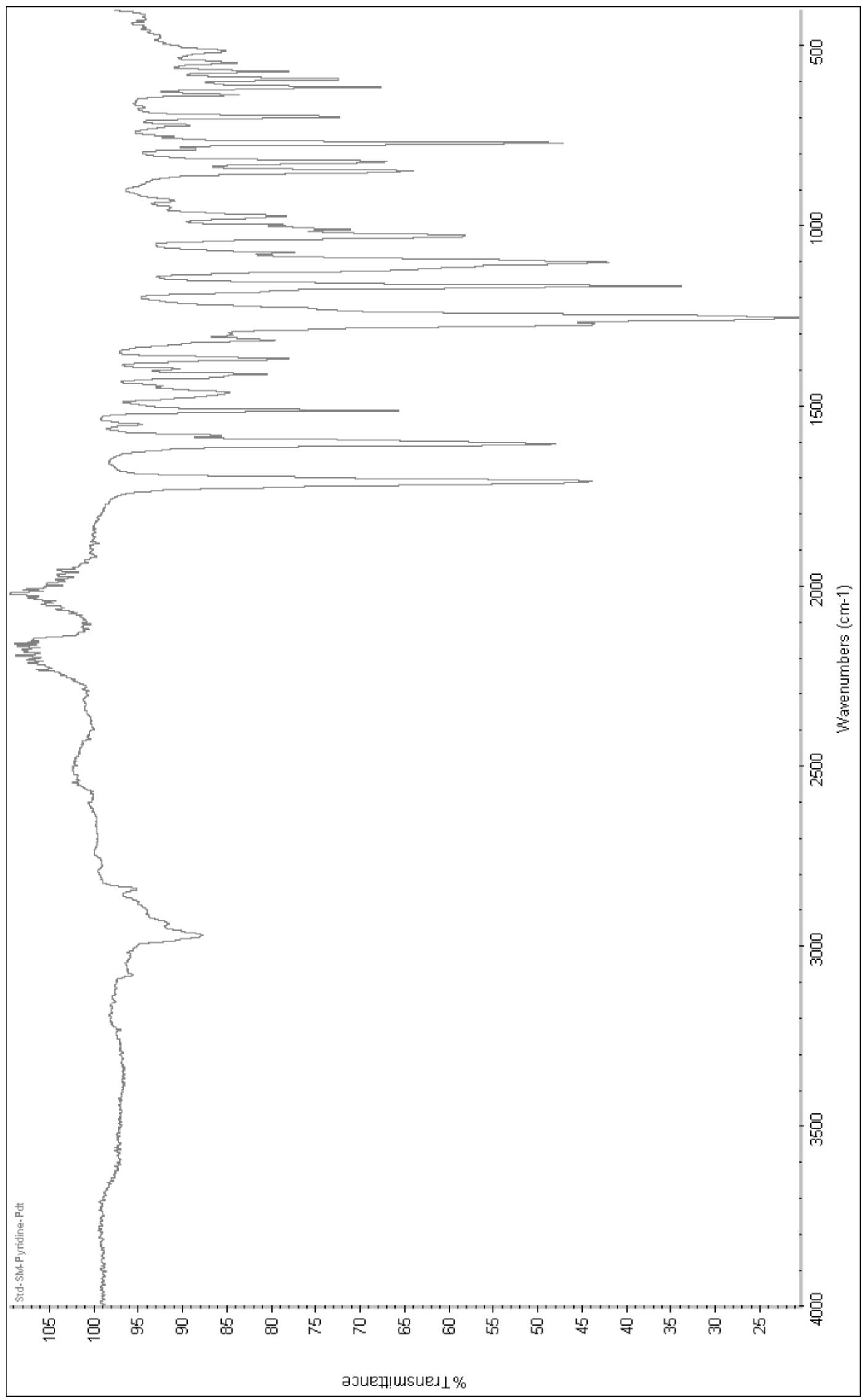

Ma and Herzon "Intermolecular hydropyridylation of unactivated alkenes" J. Am. Chem. Soc. 


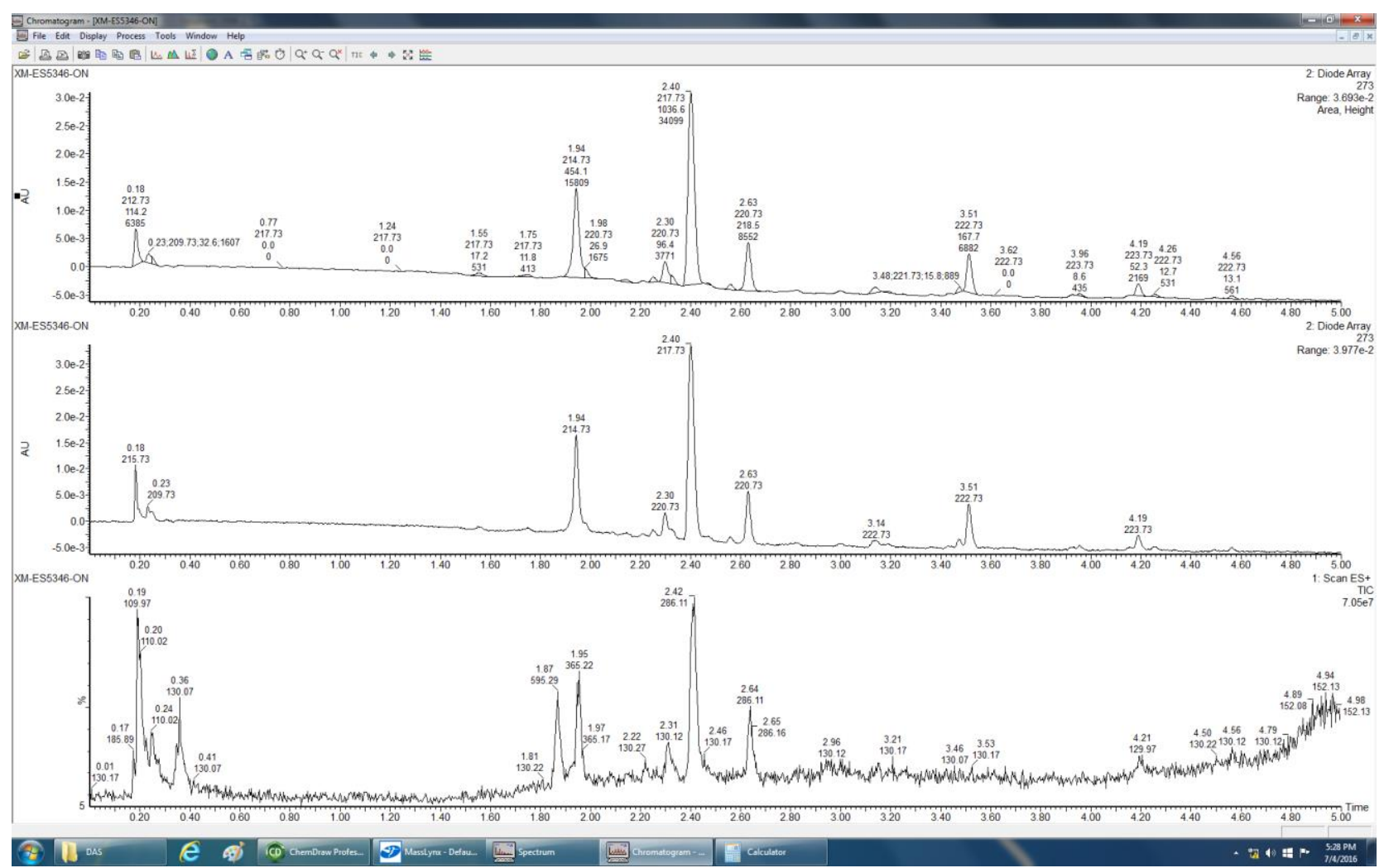




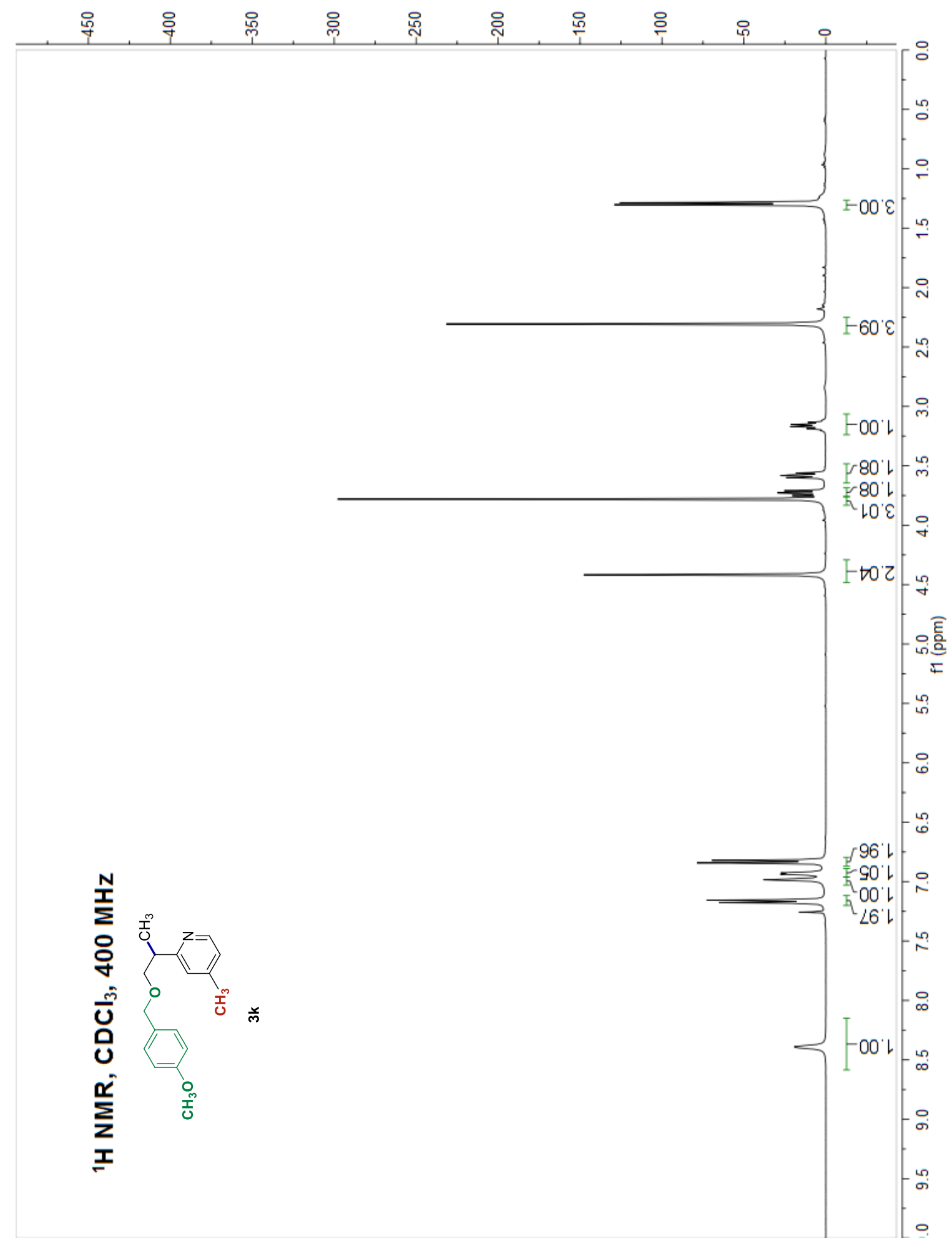




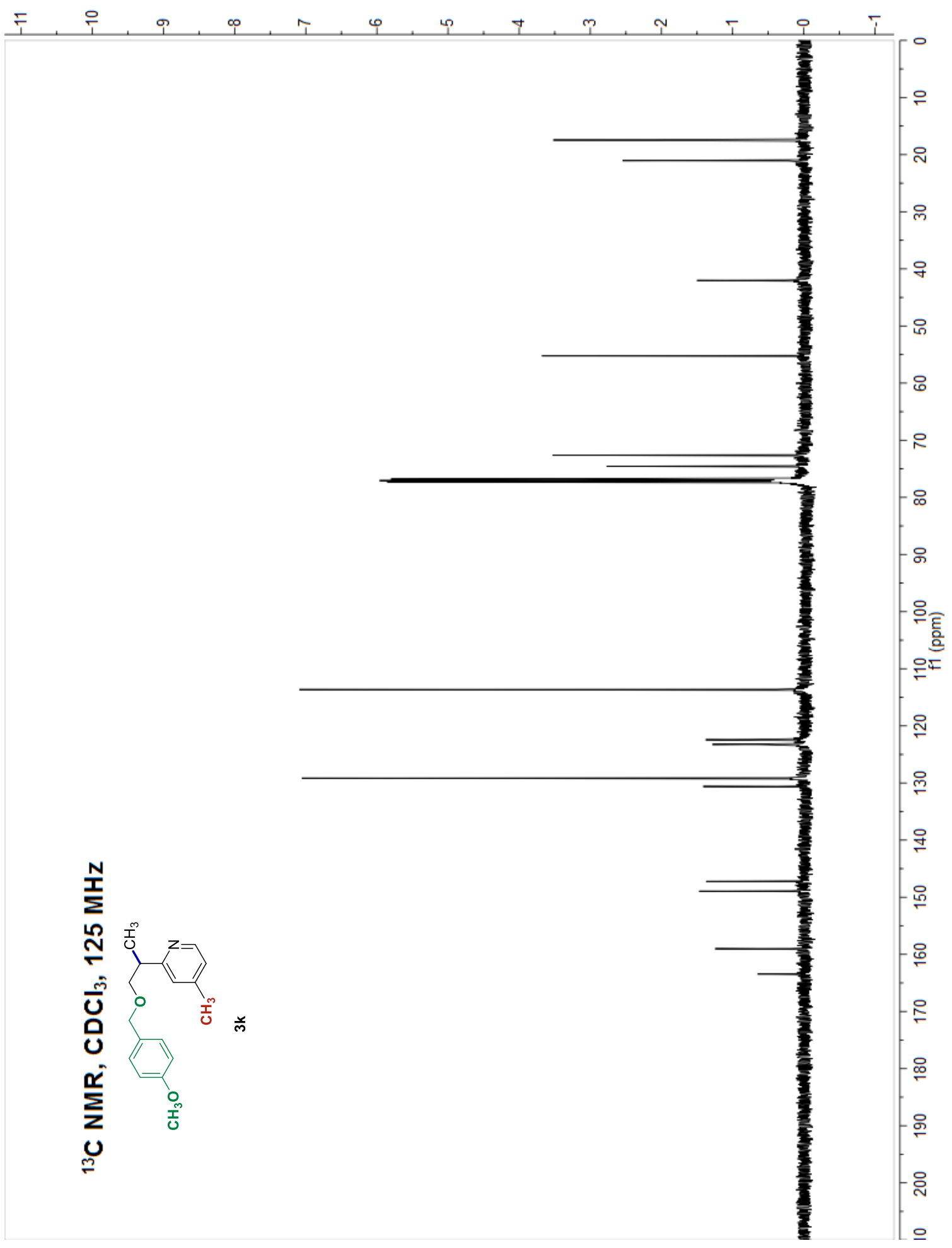




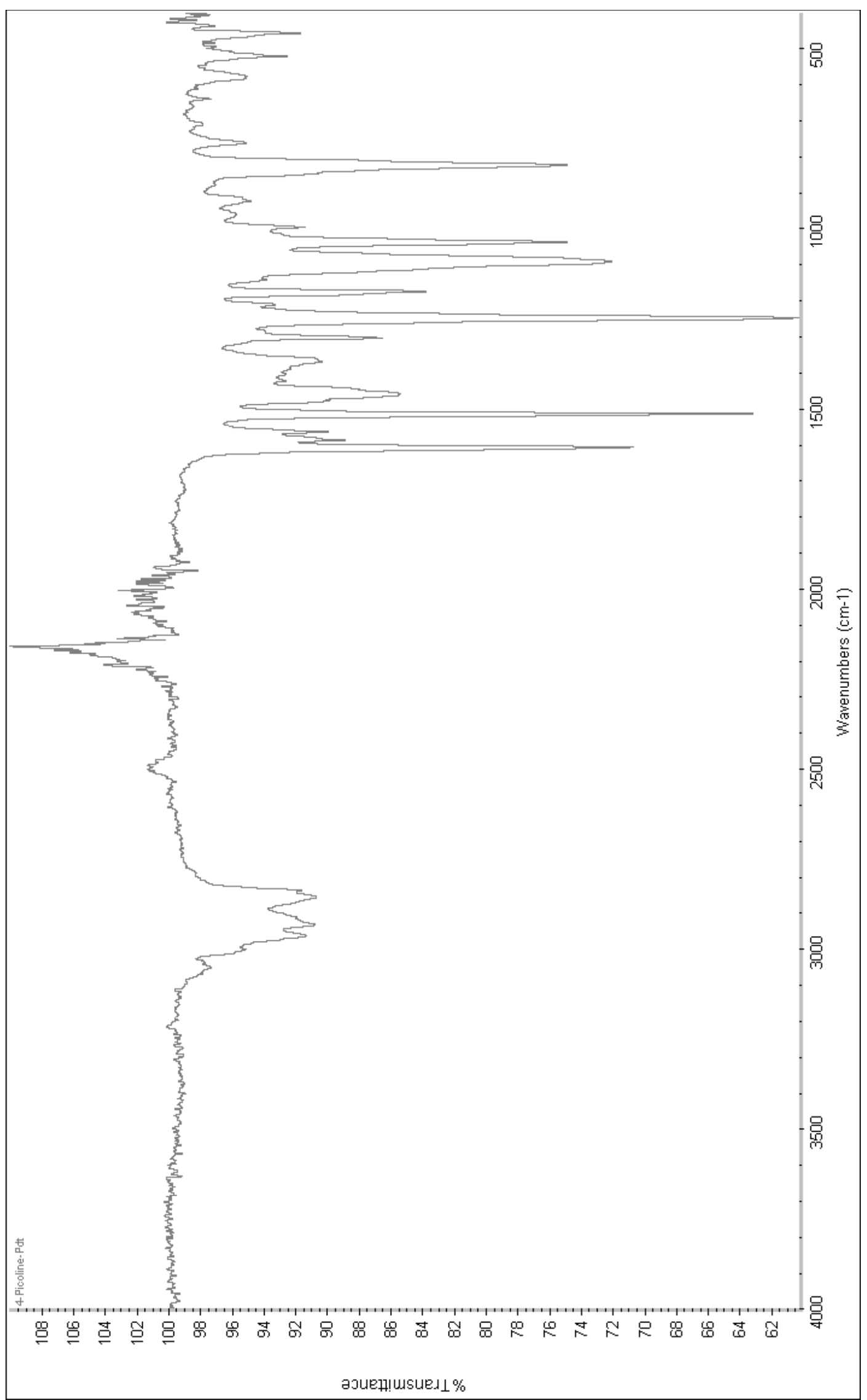

Ma and Herzon "Intermolecular hydropyridylation of unactivated alkenes" J. Am. Chem. Soc. 


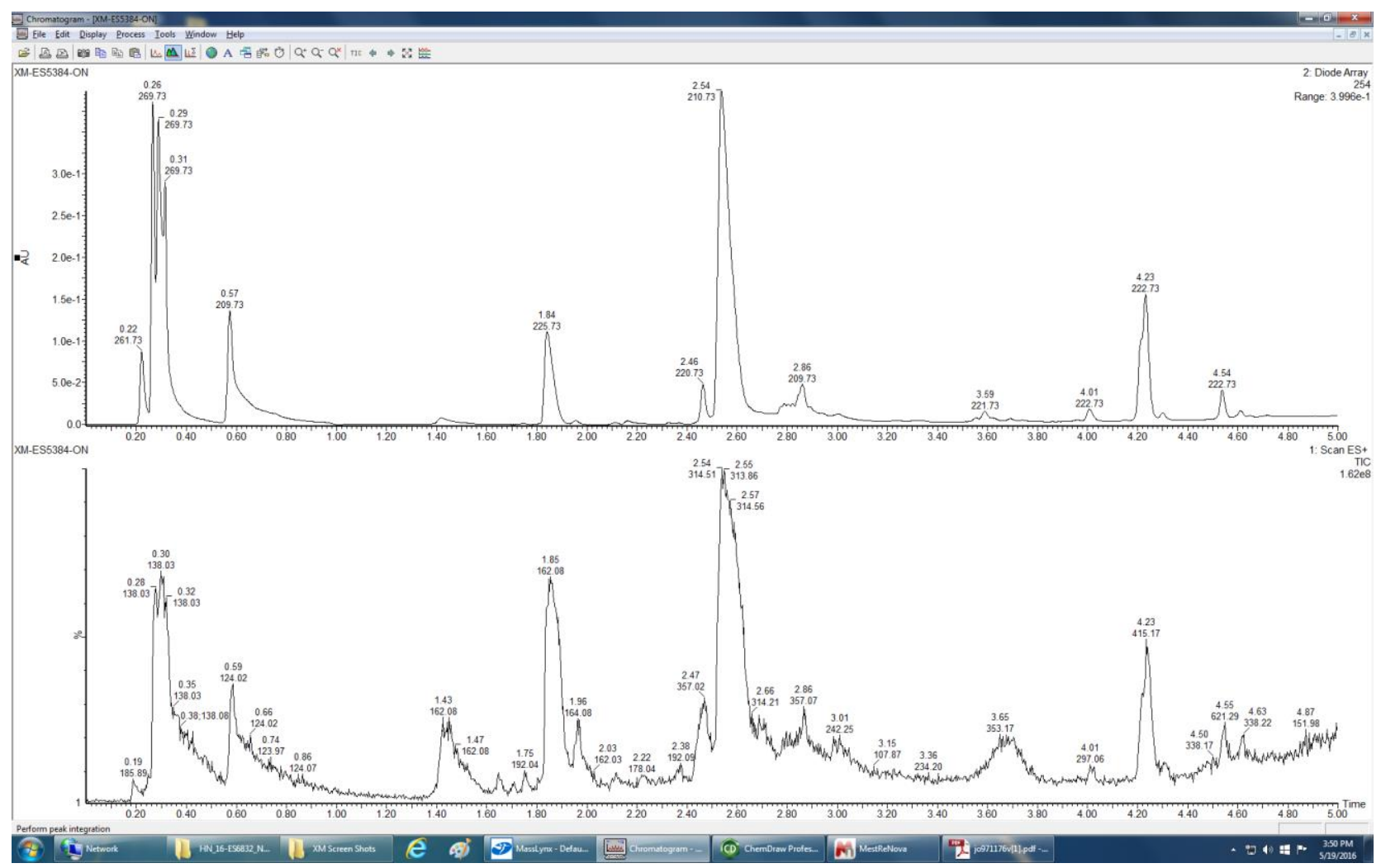




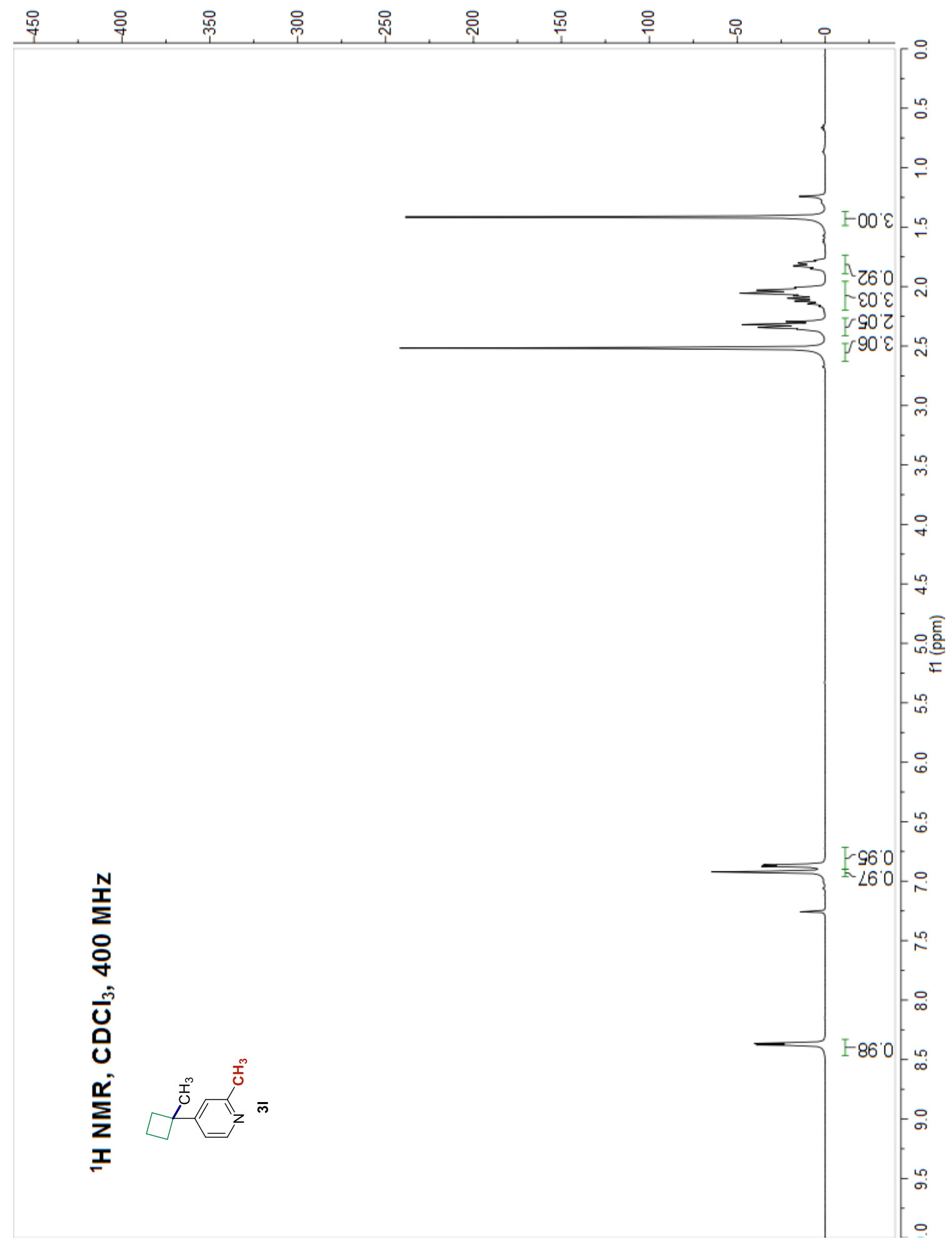




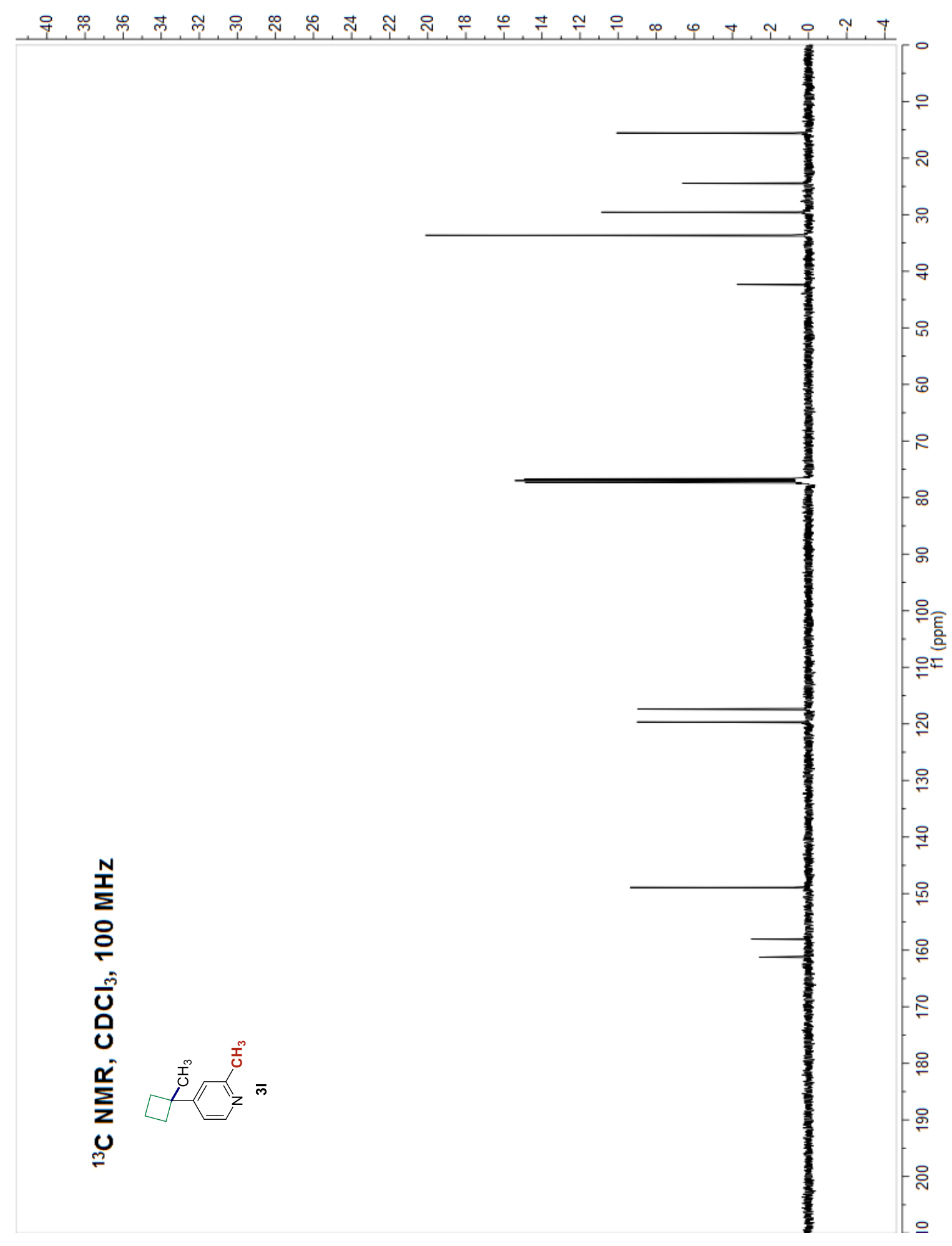




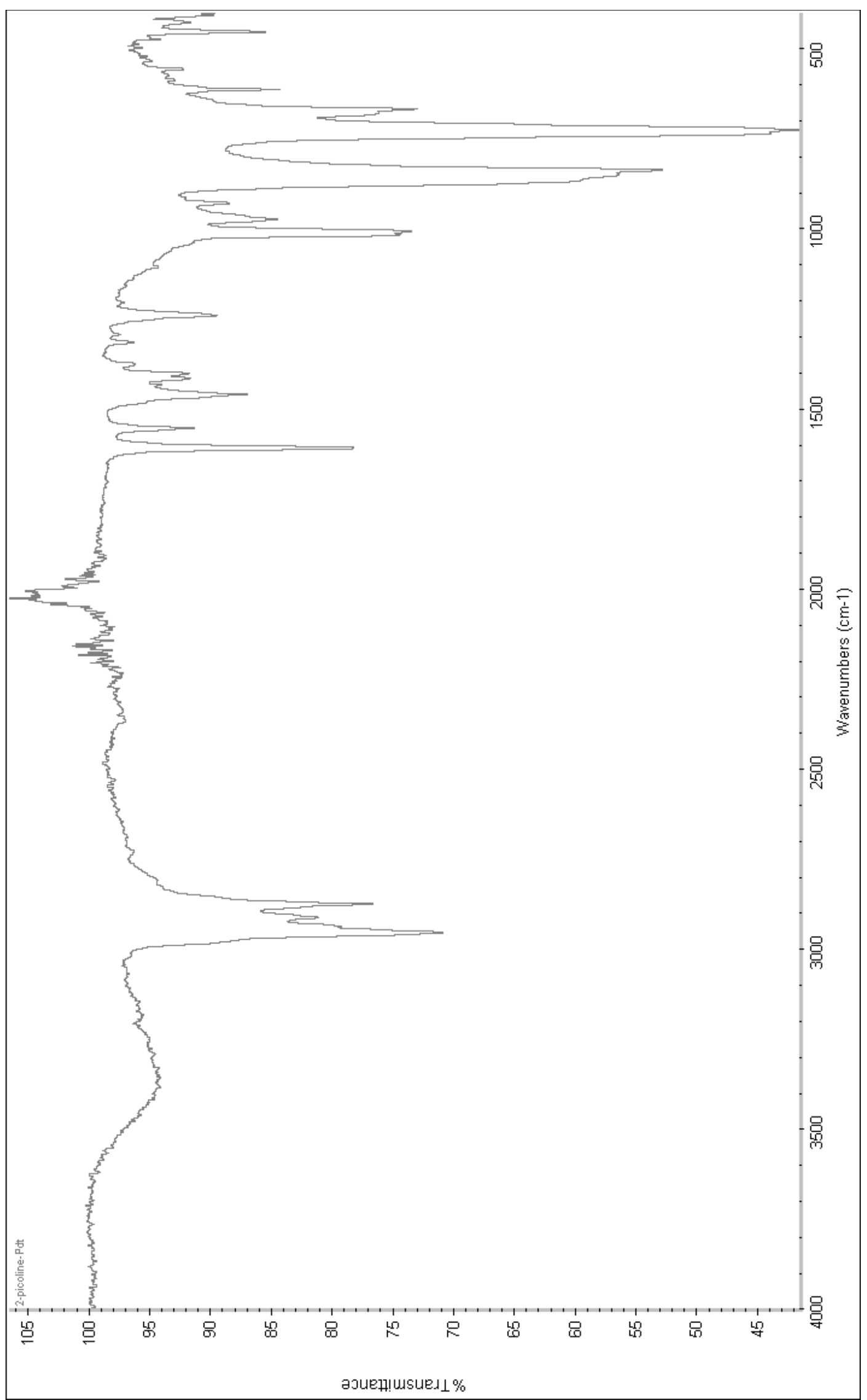

Ma and Herzon "Intermolecular hydropyridylation of unactivated alkenes" J. Am. Chem. Soc. 


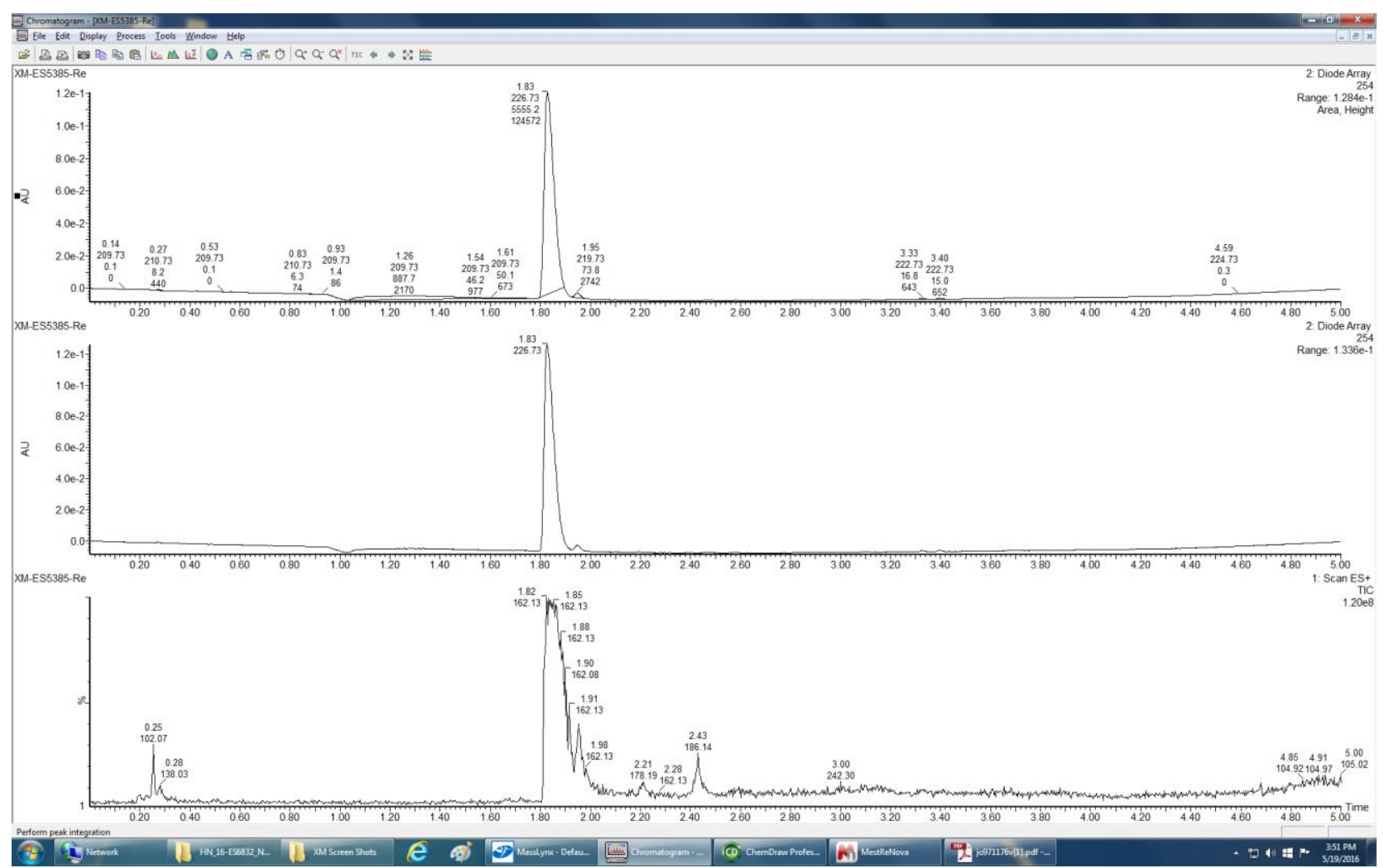




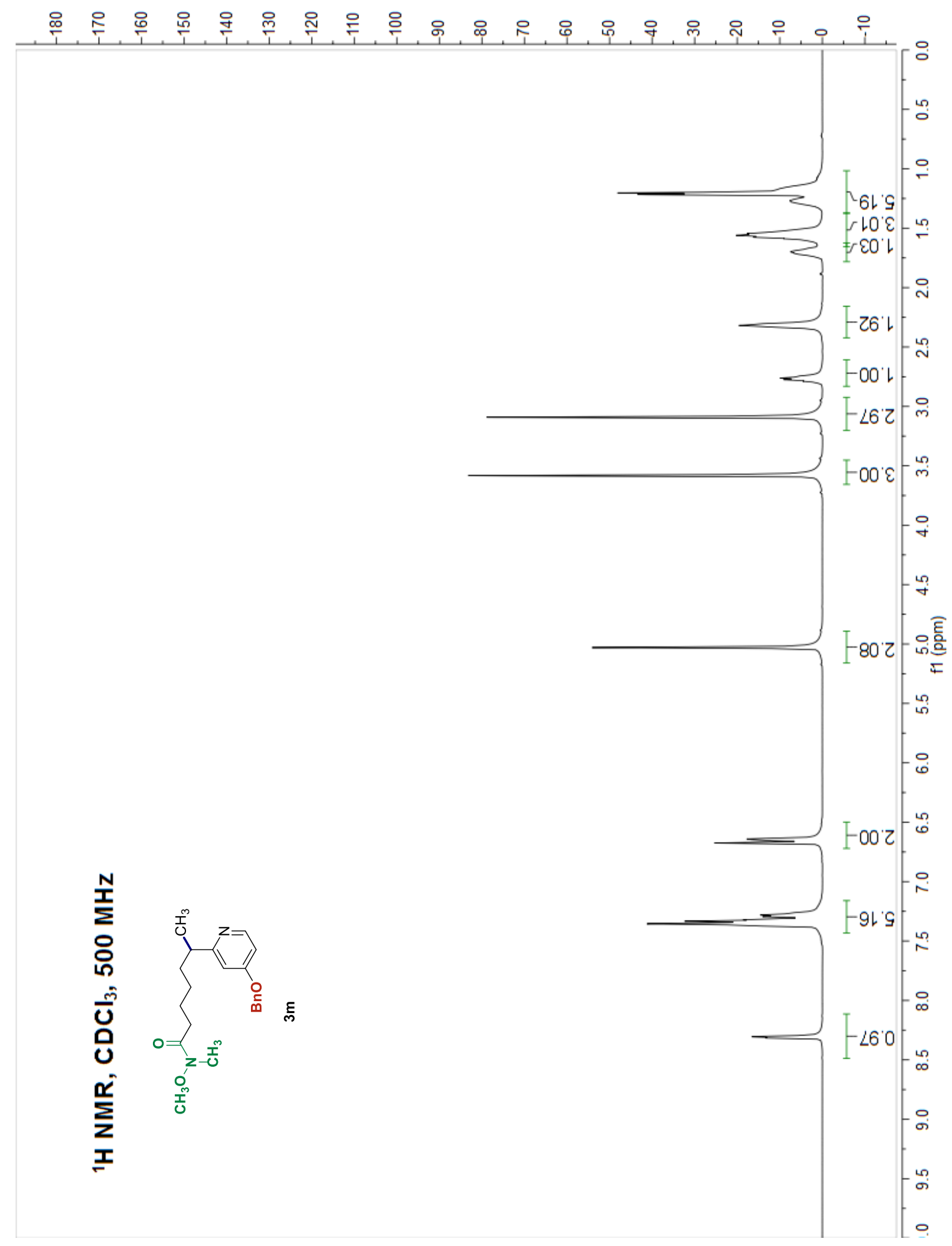




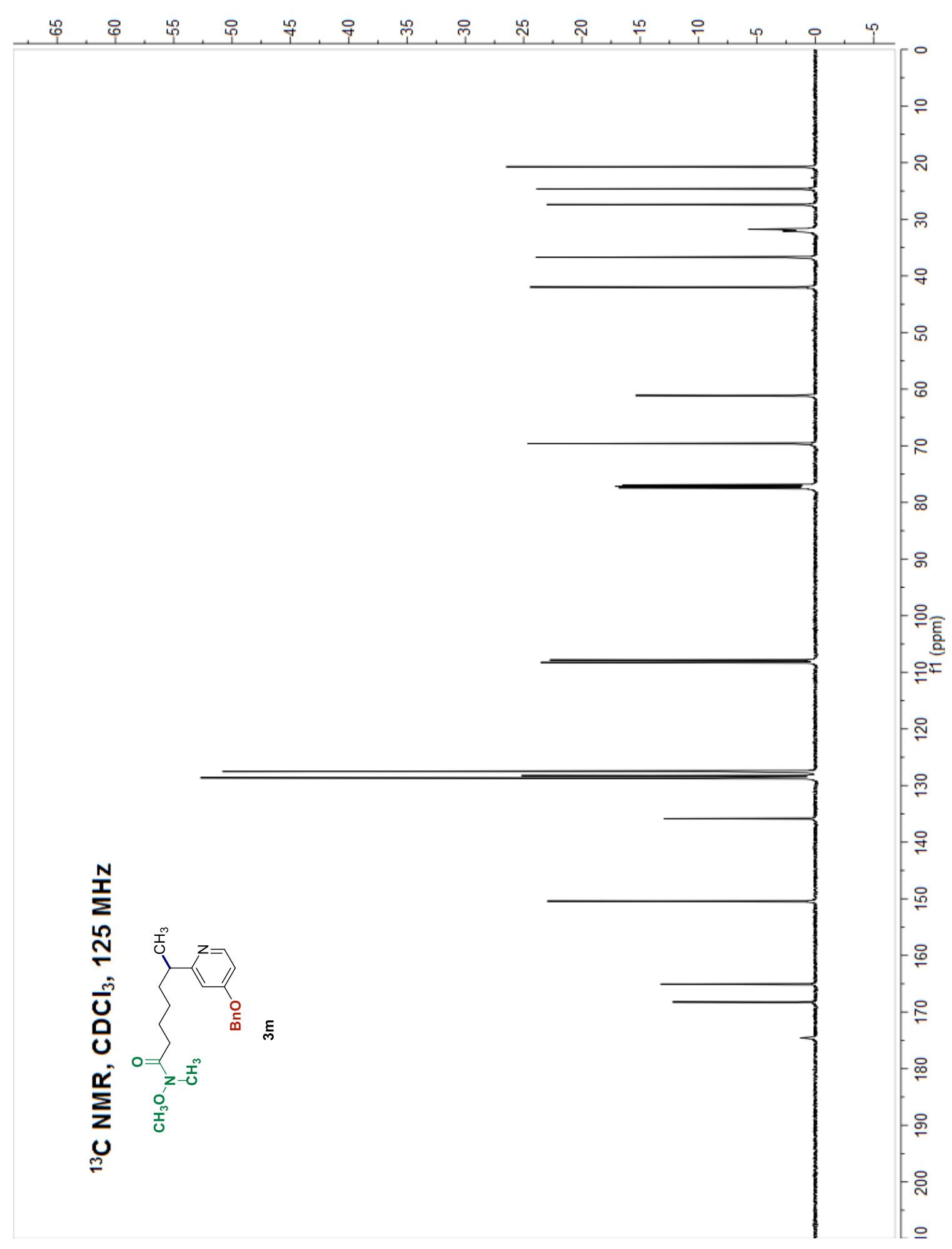




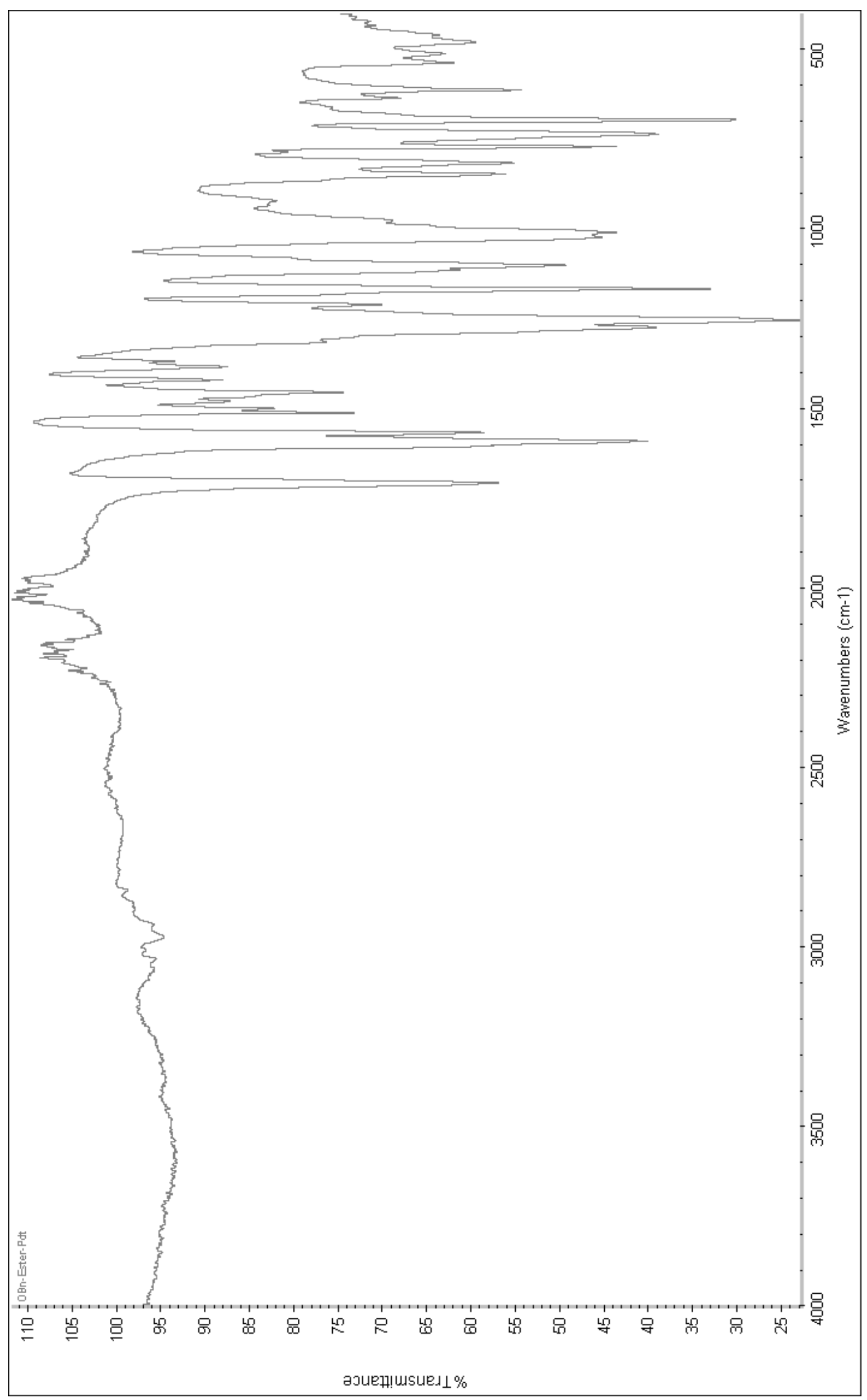




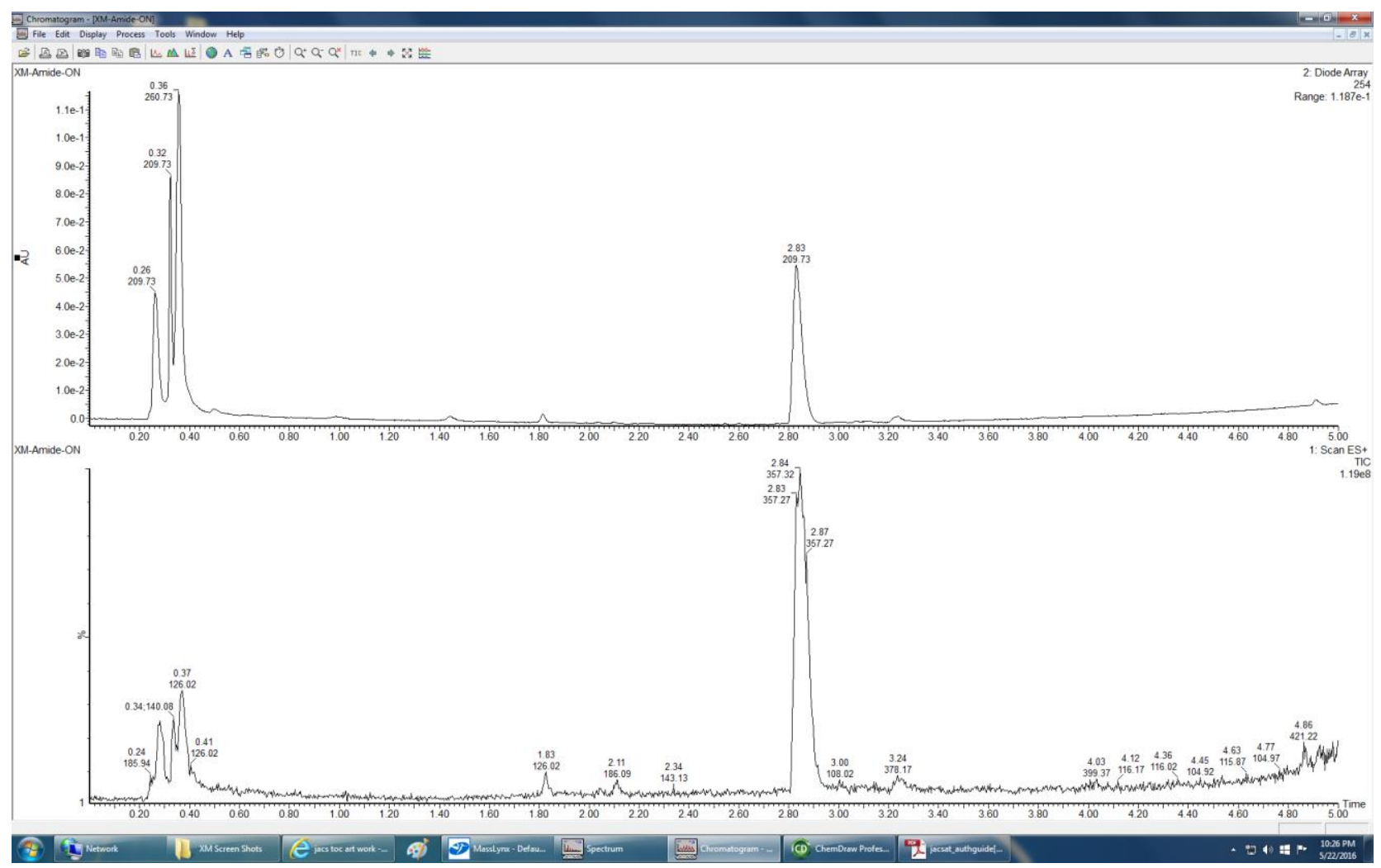




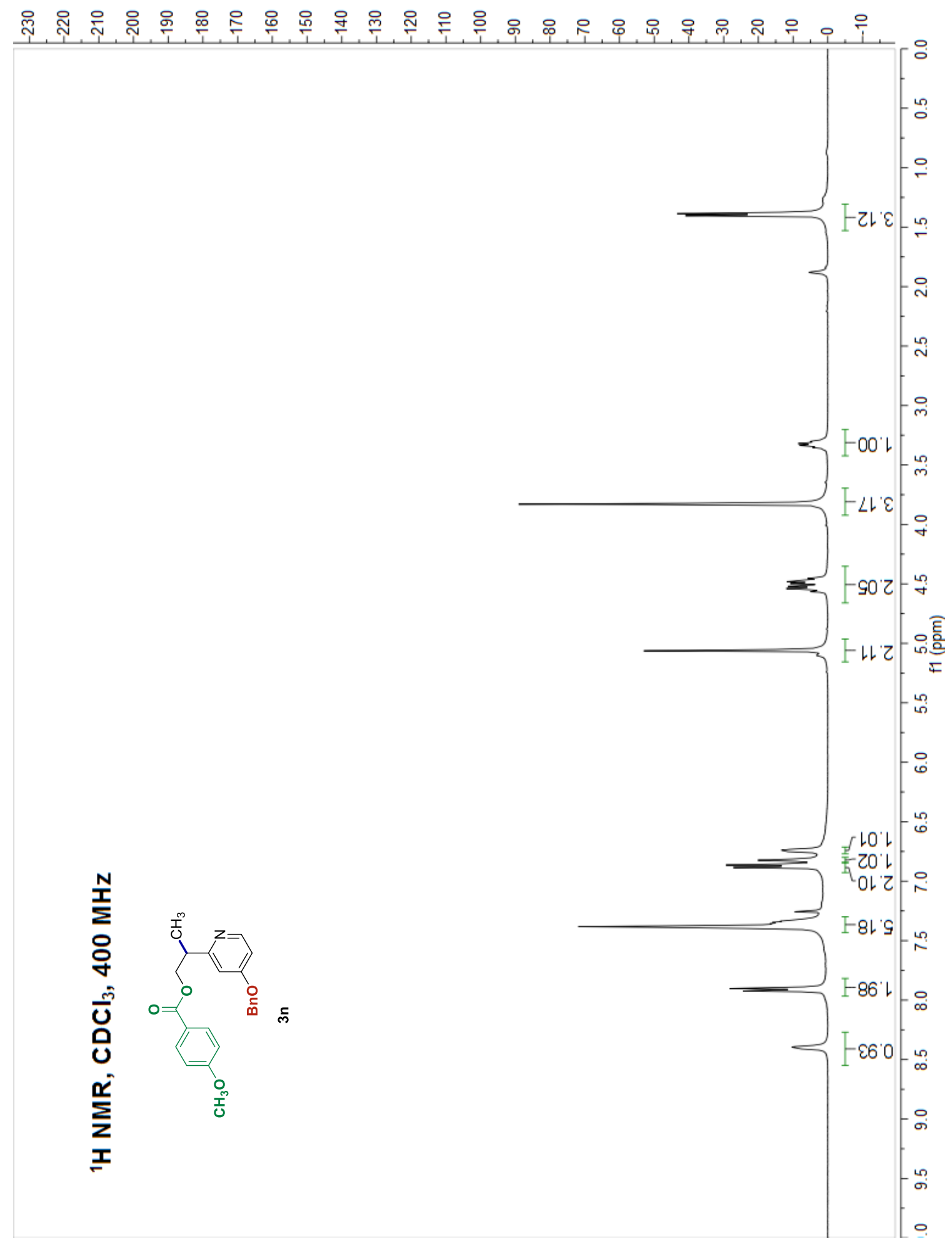




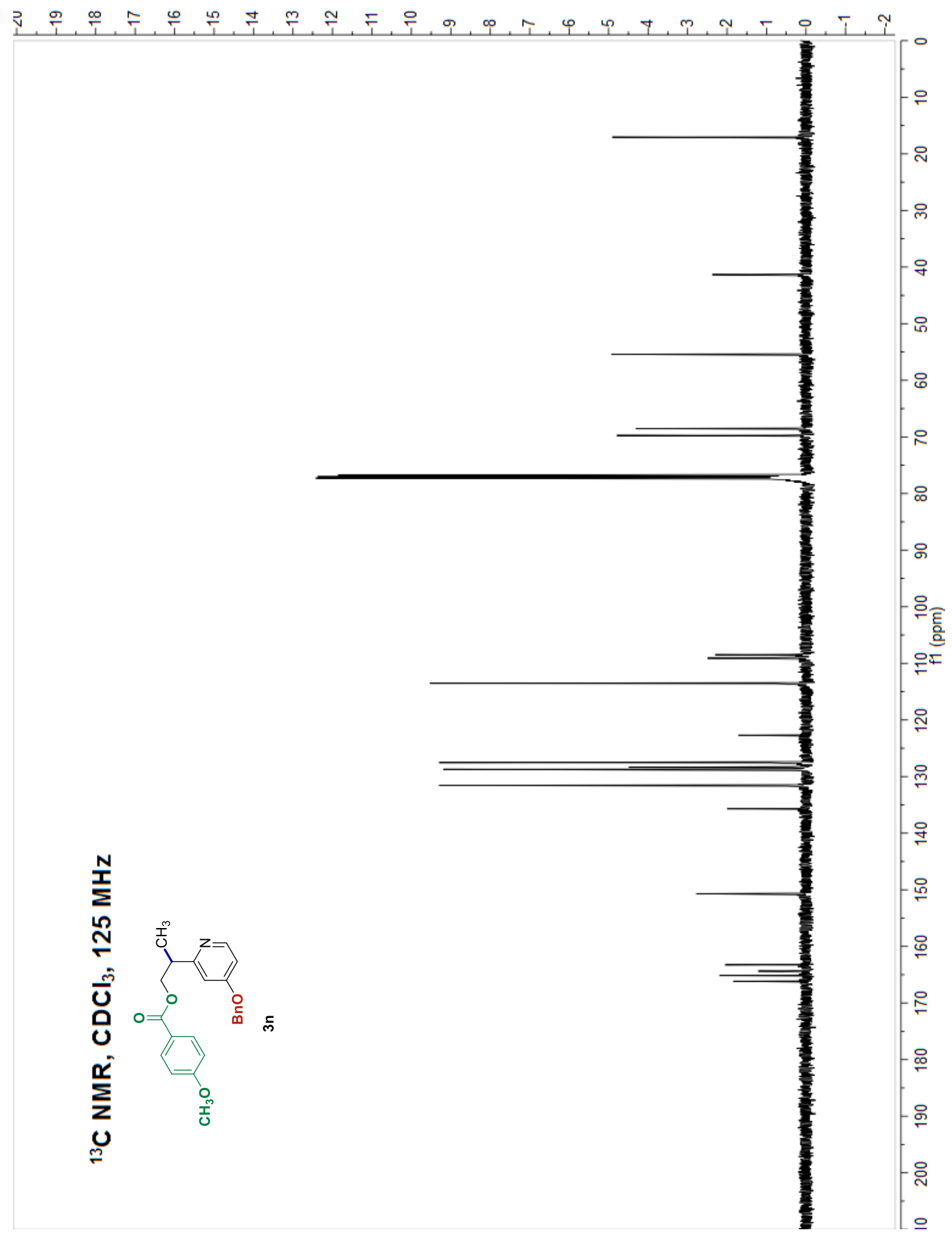




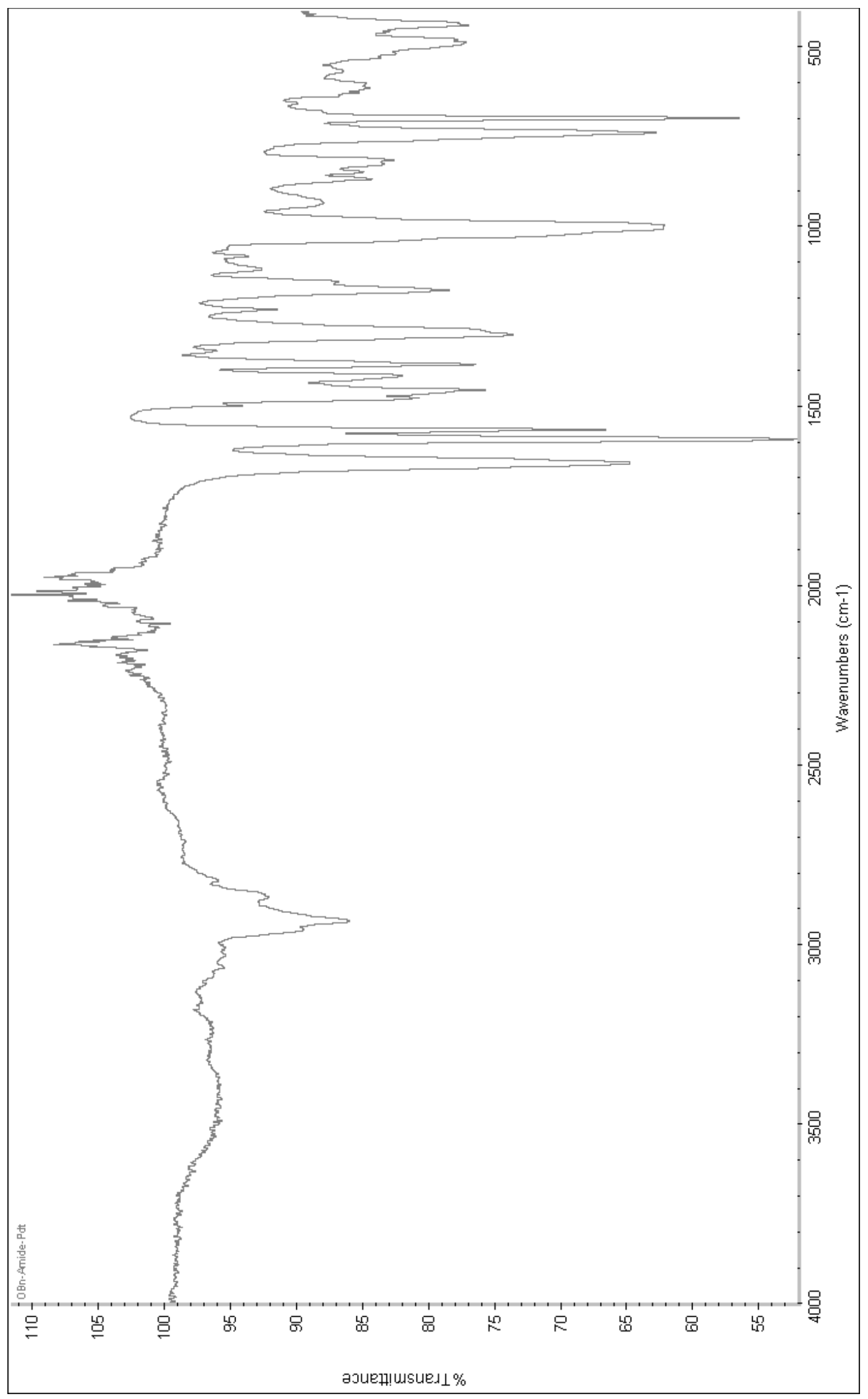

Ma and Herzon "Intermolecular hydropyridylation of unactivated alkenes" J. Am. Chem. Soc. 


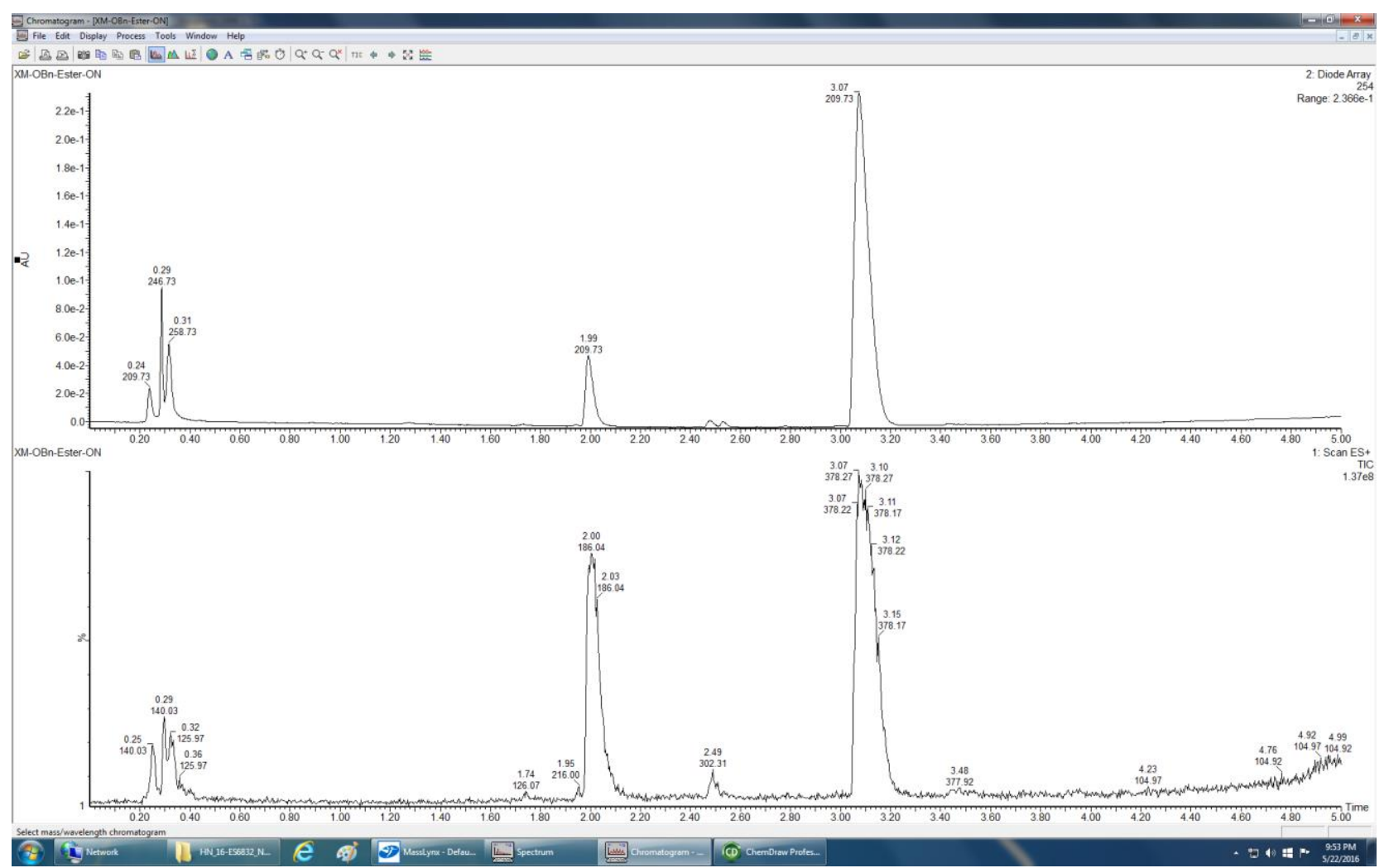




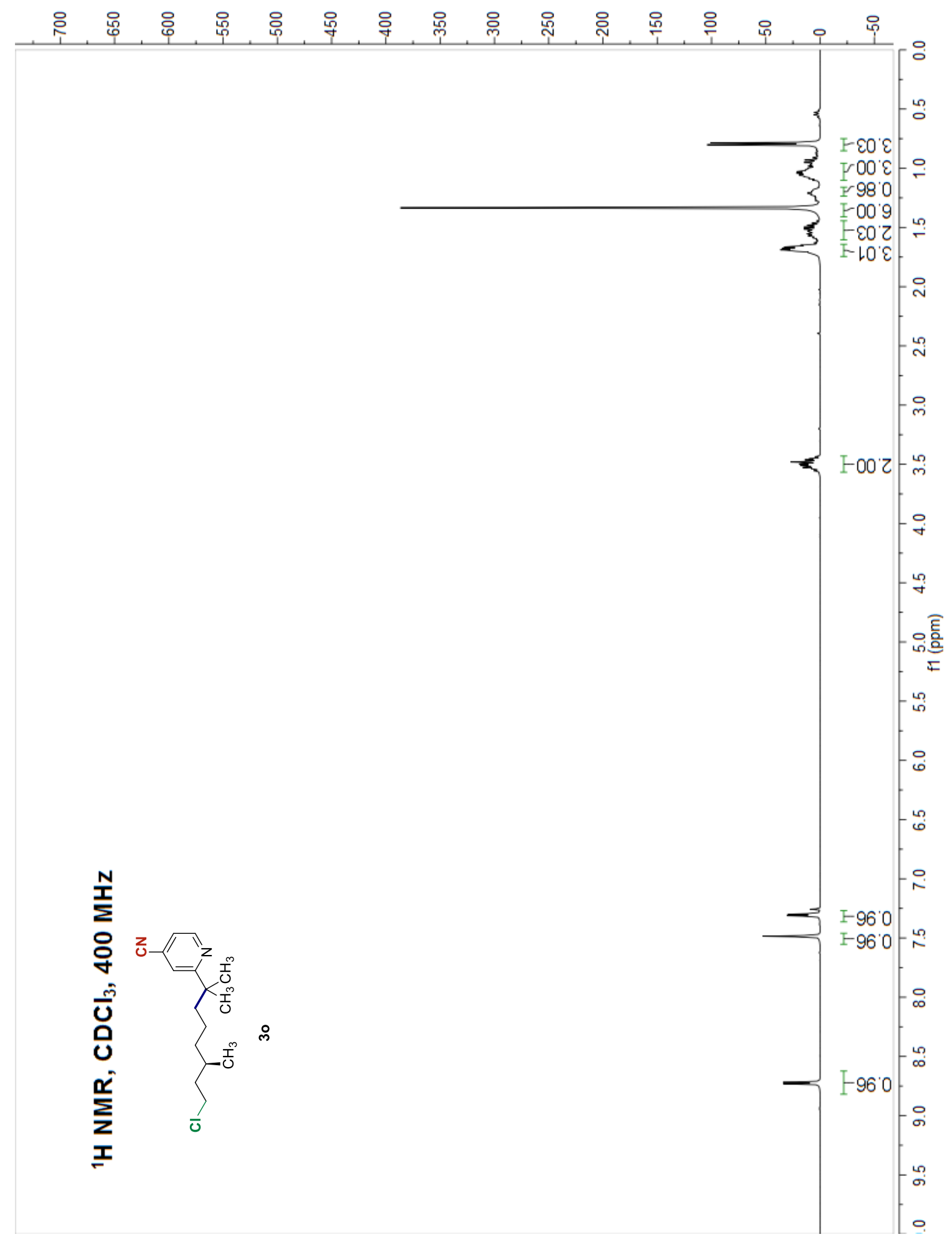




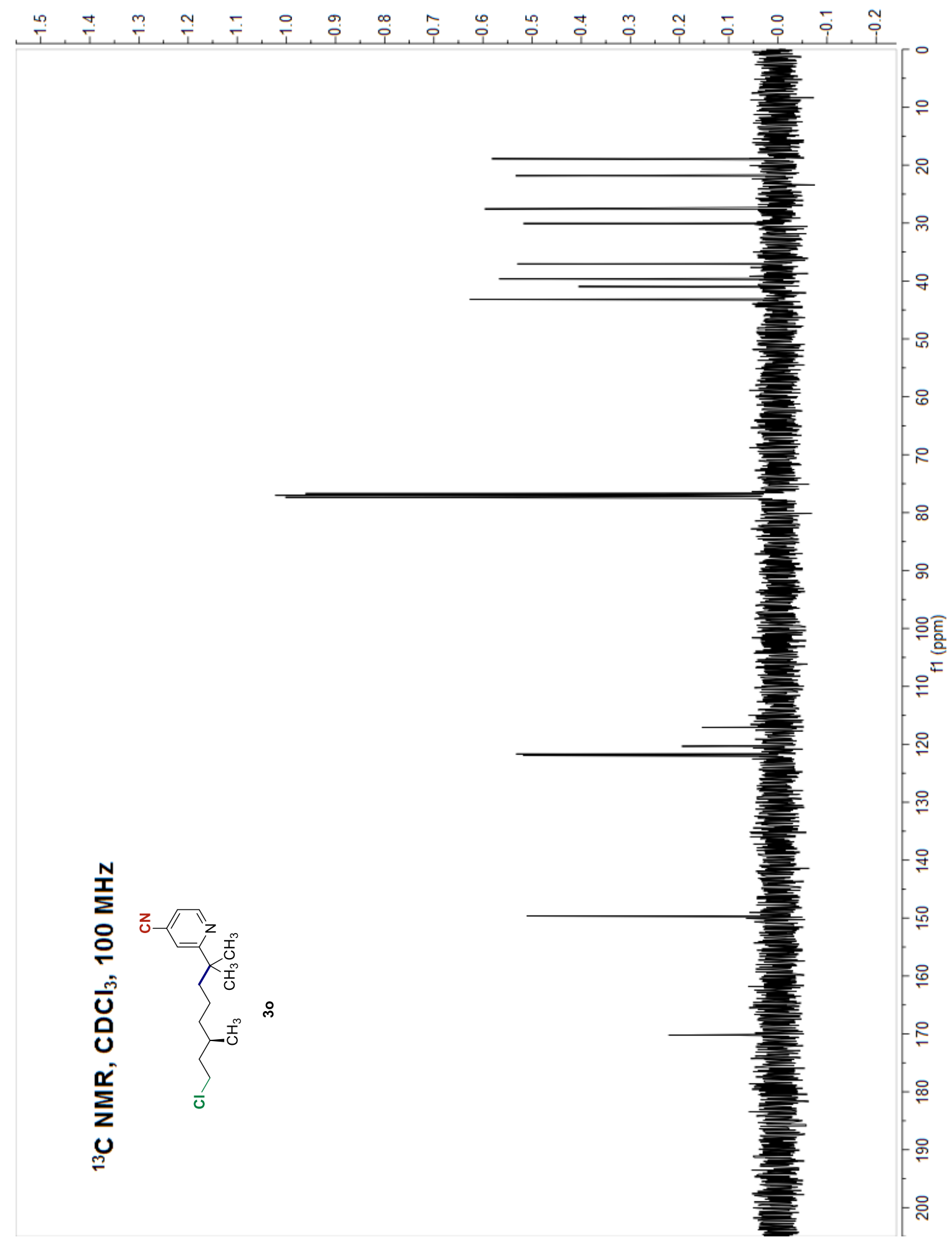




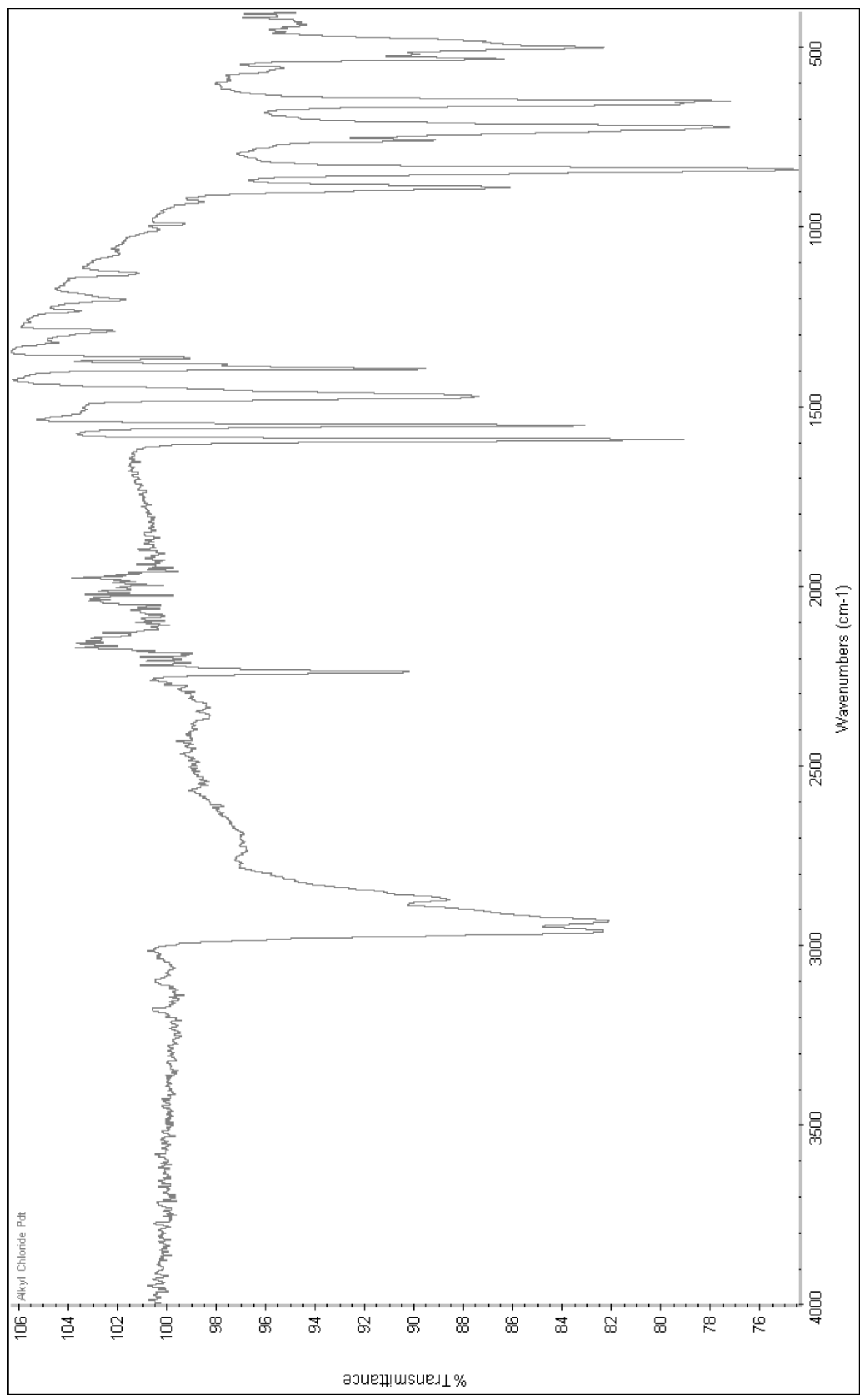

Ma and Herzon "Intermolecular hydropyridylation of unactivated alkenes" J. Am. Chem. Soc. 


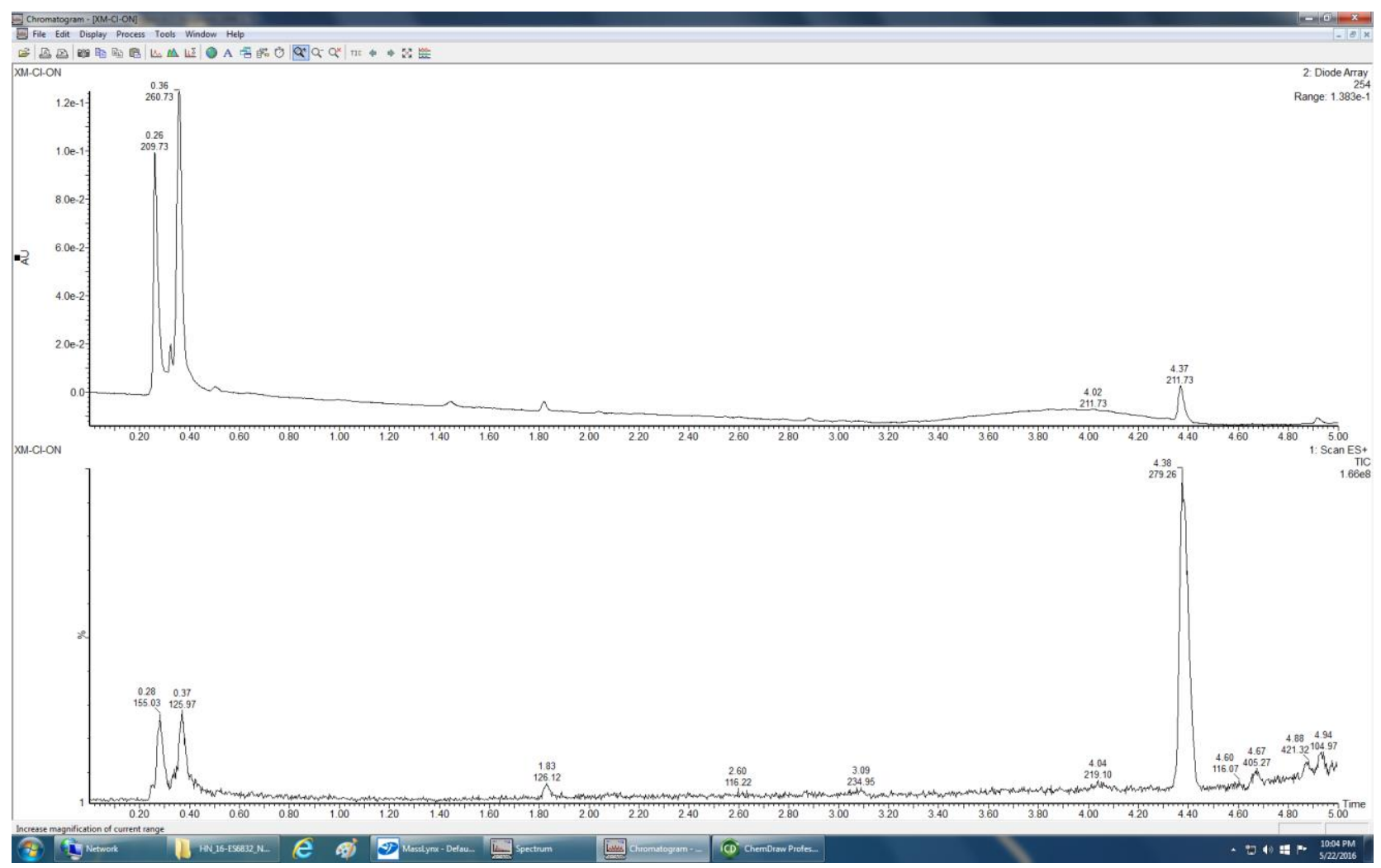




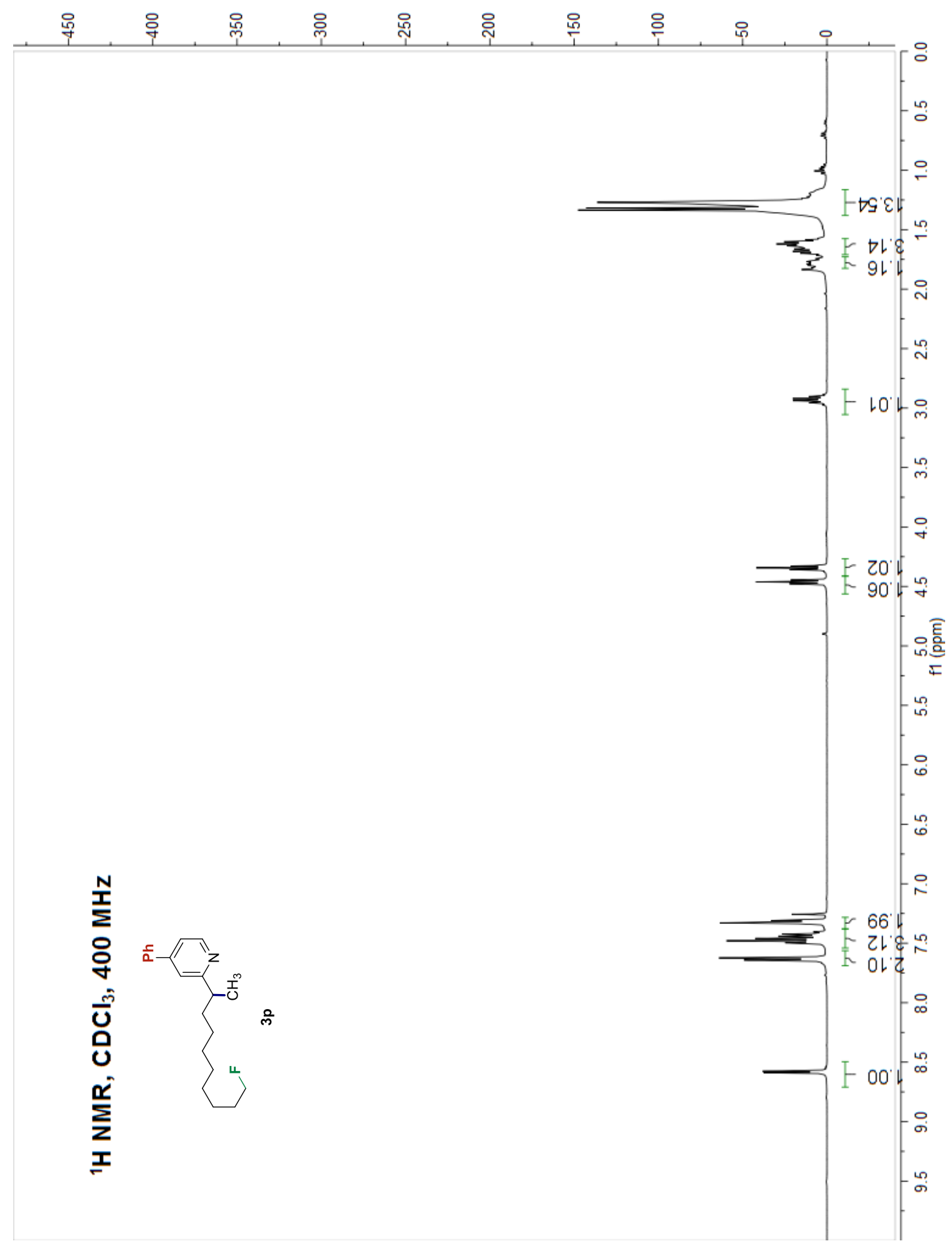




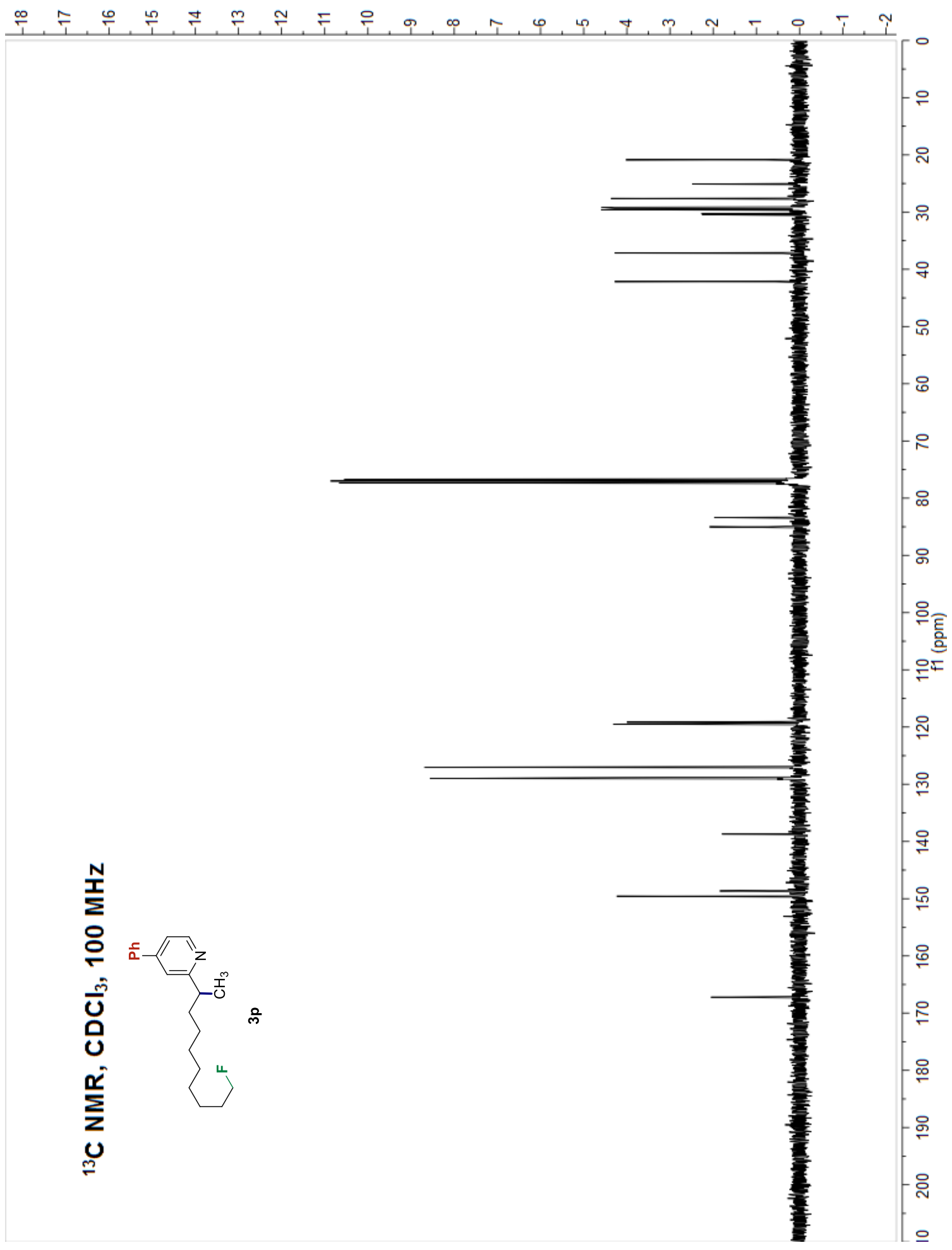




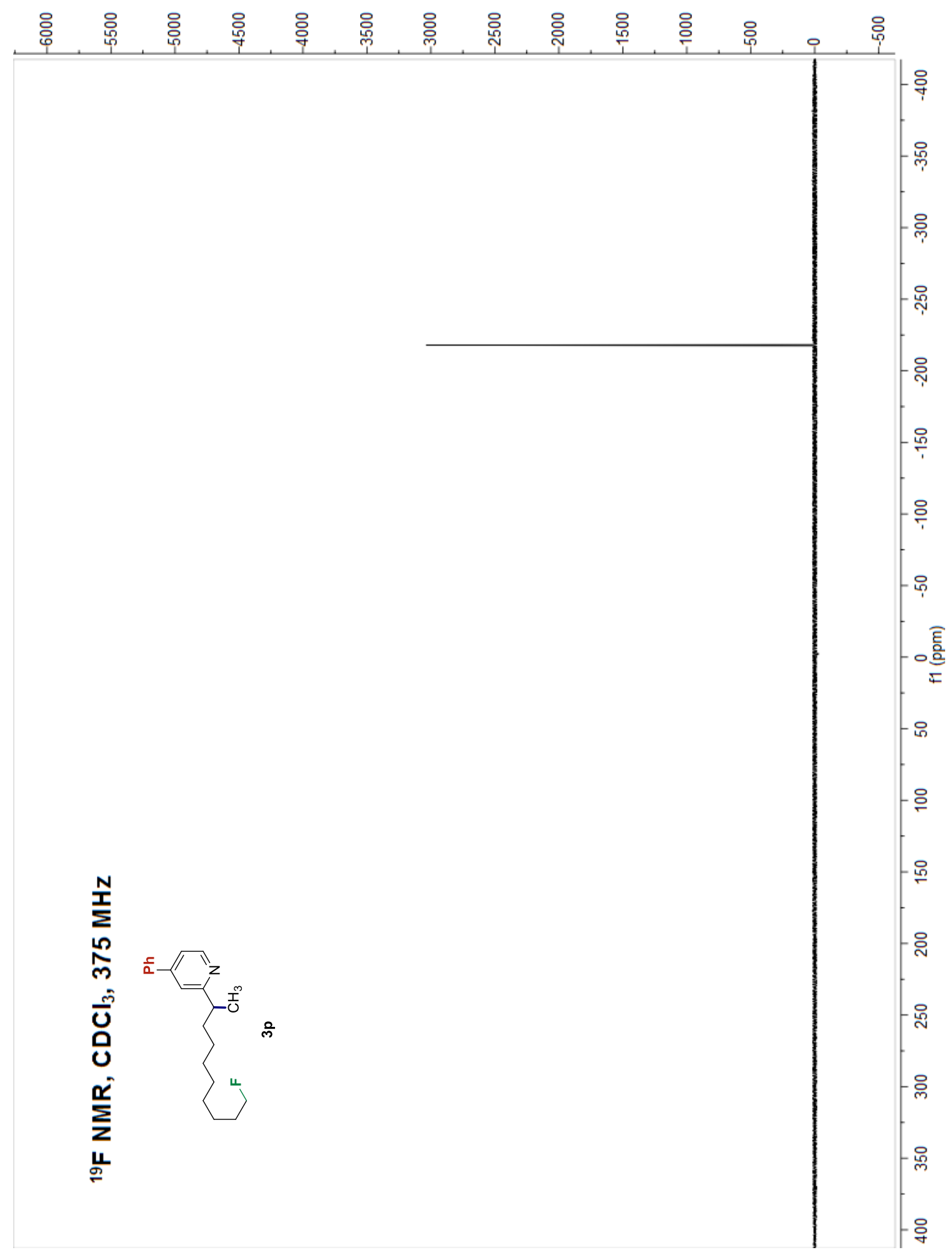




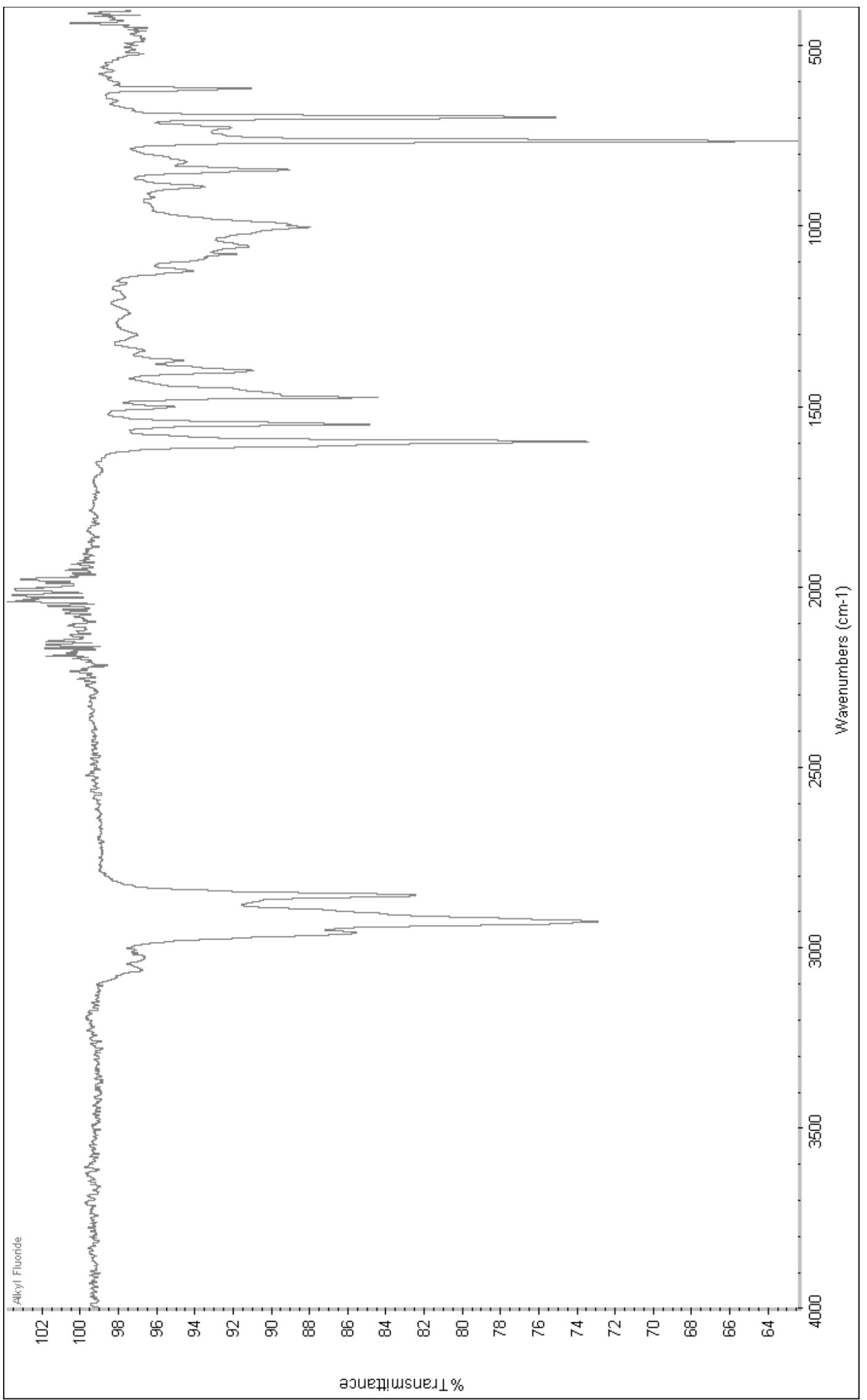

Ma and Herzon "Intermolecular hydropyridylation of unactivated alkenes" J. Am. Chem. Soc. 


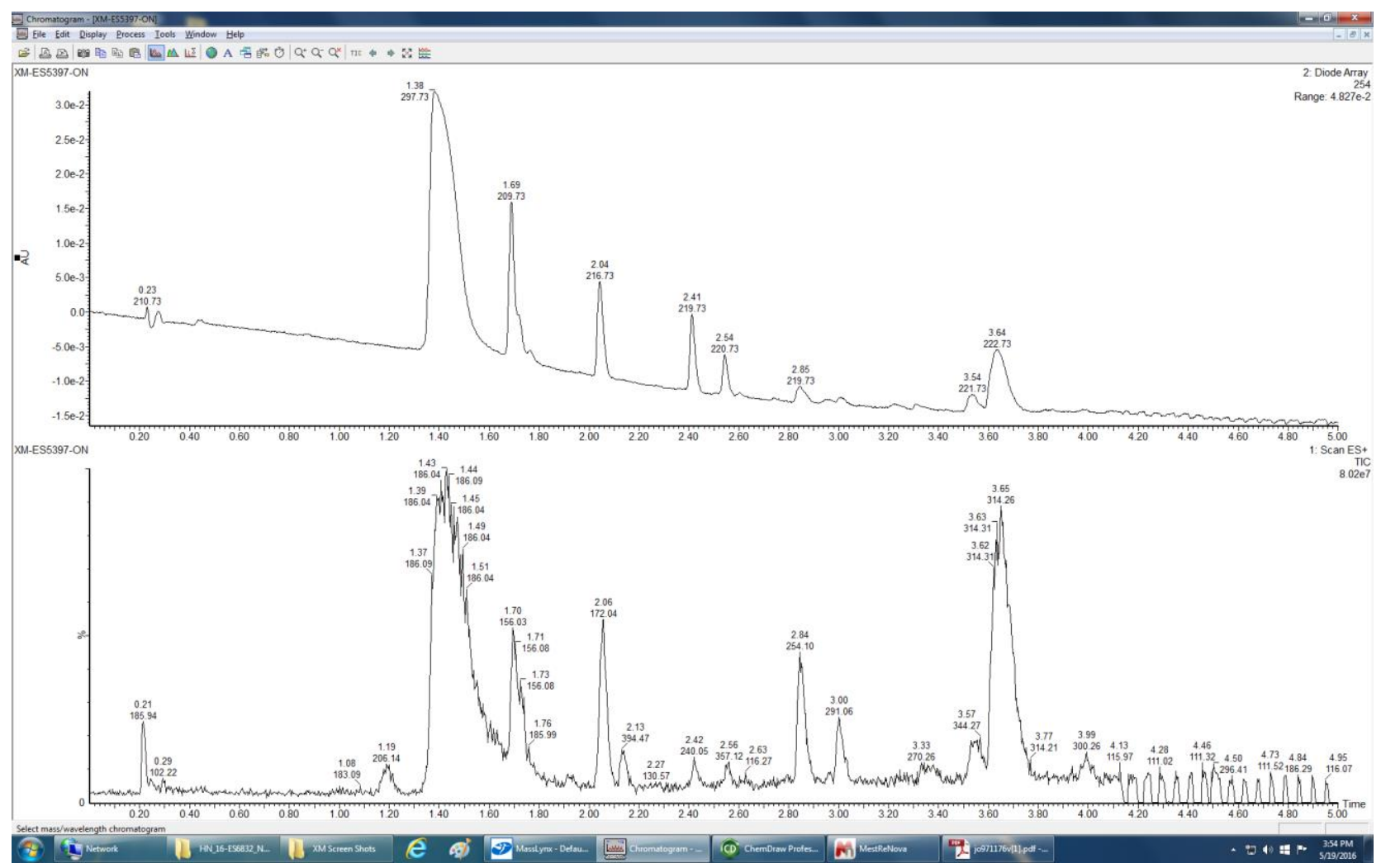




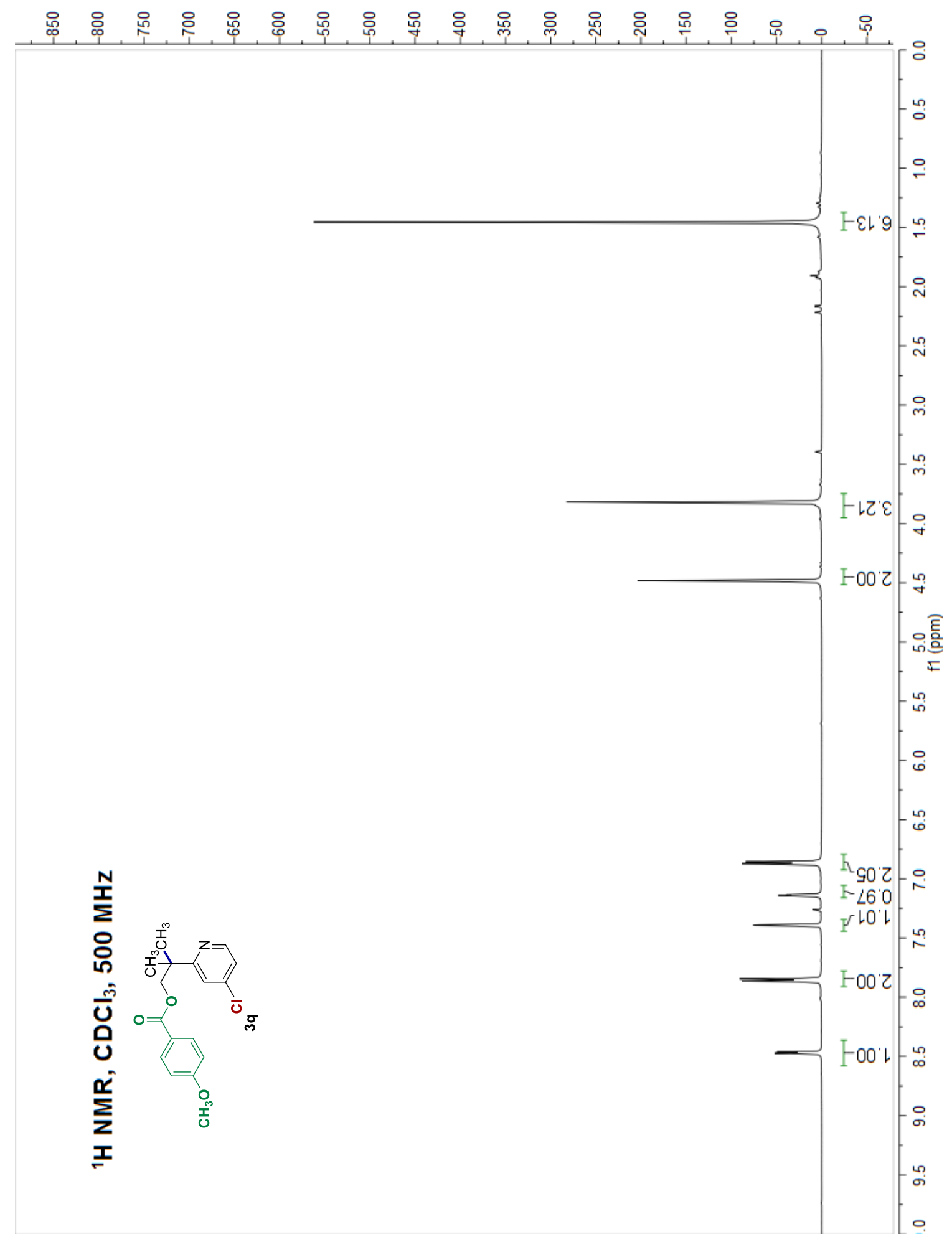




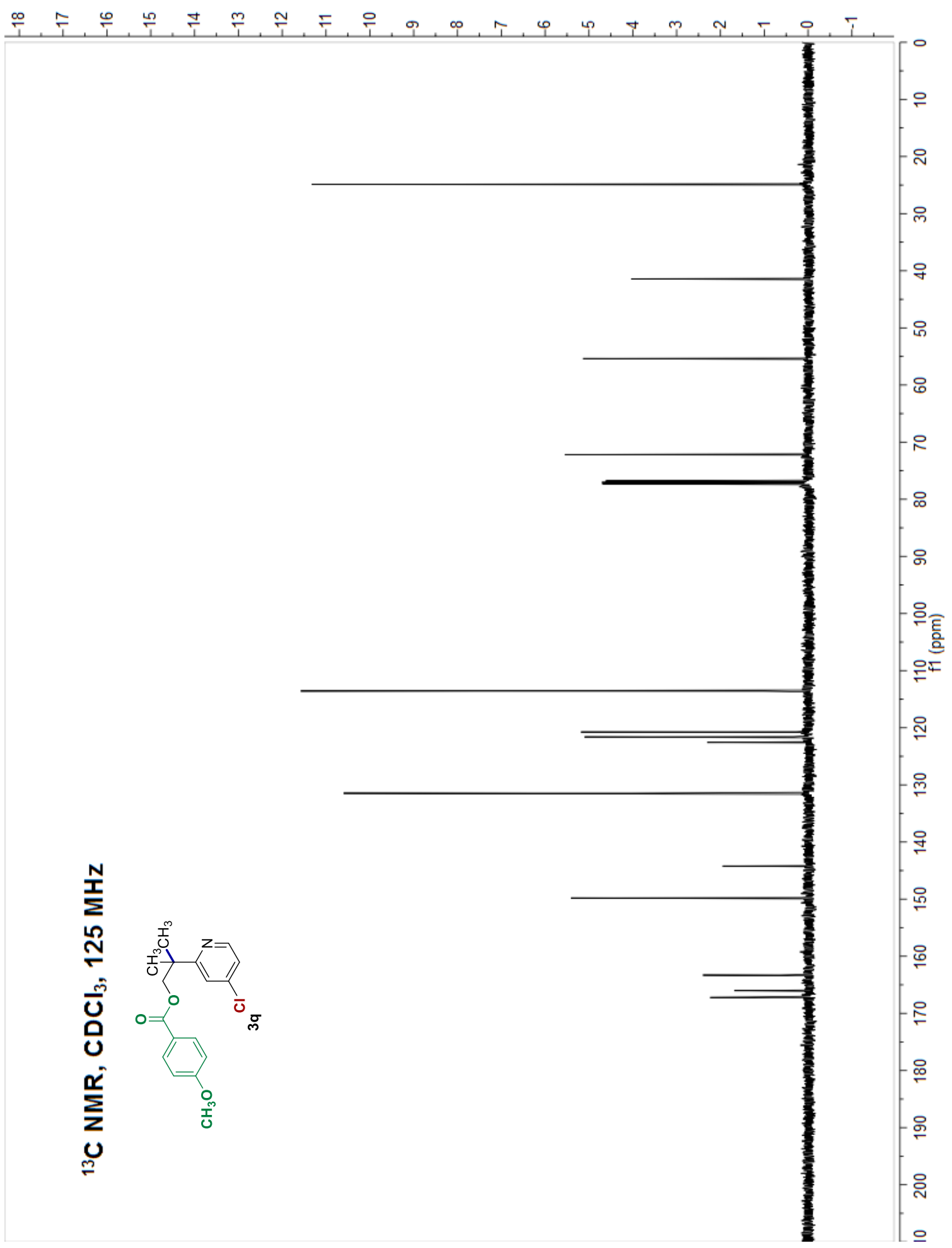




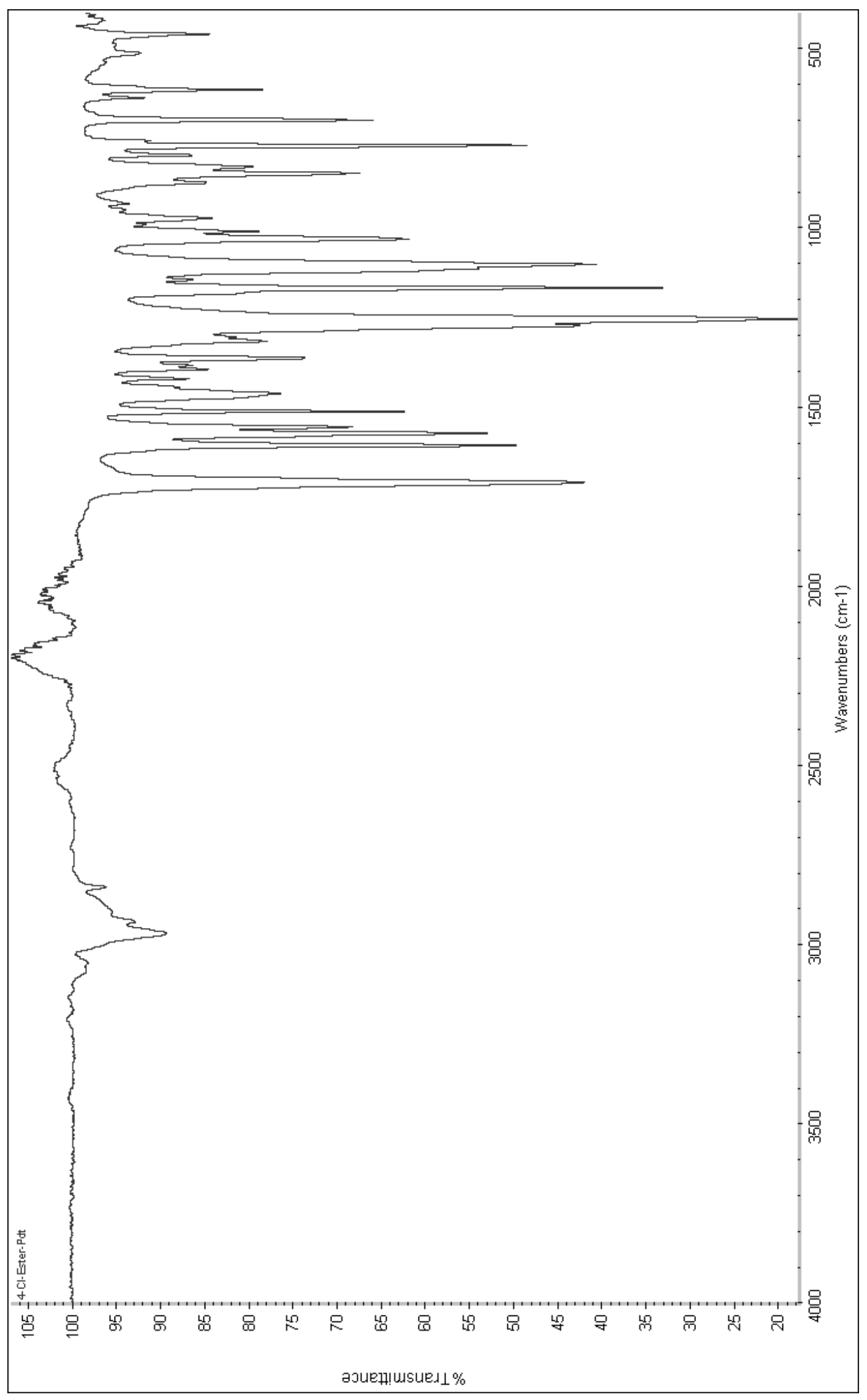




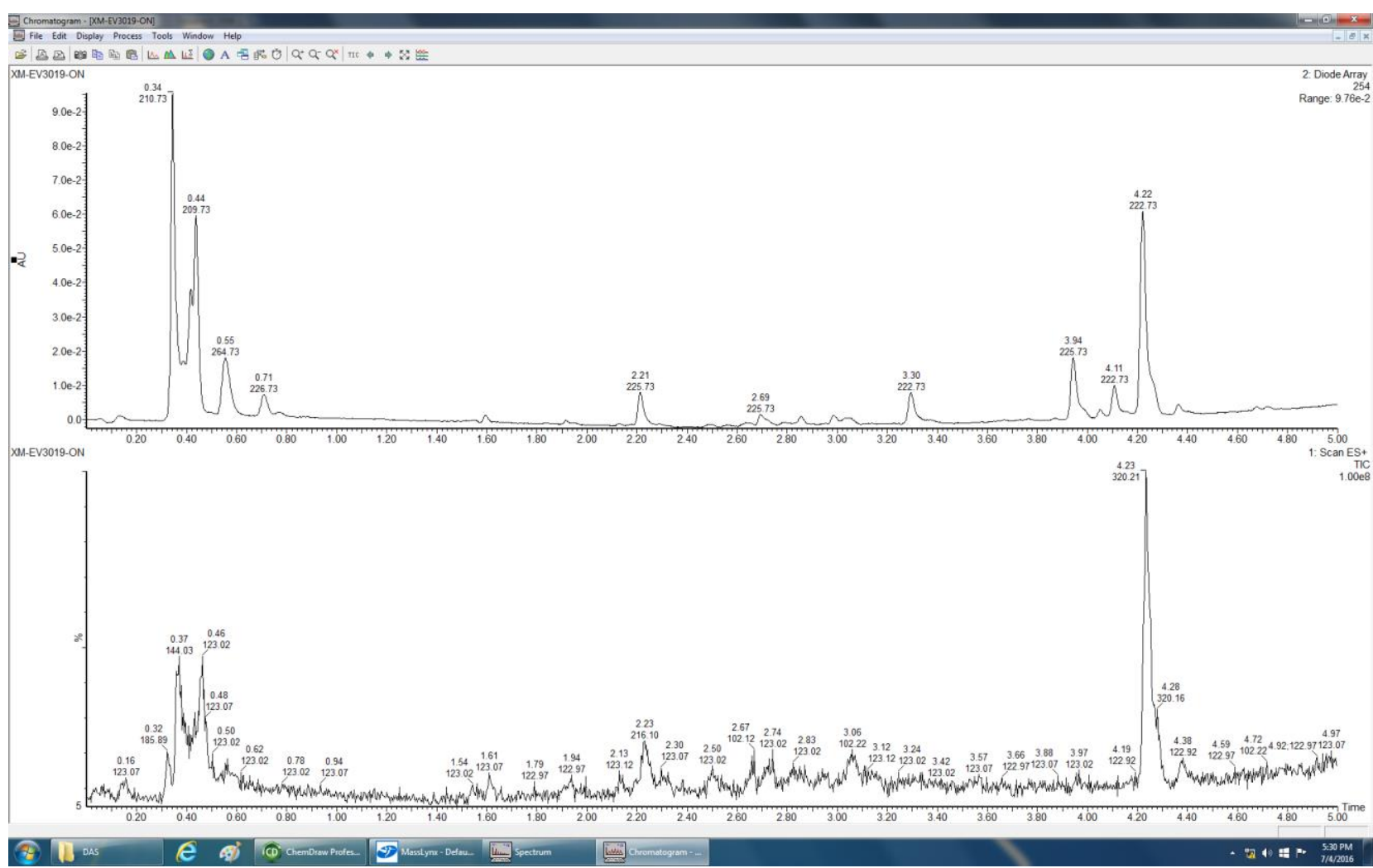

Ma and Herzon "Intermolecular hydropyridylation of unactivated alkenes" J. Am. Chem. Soc. 


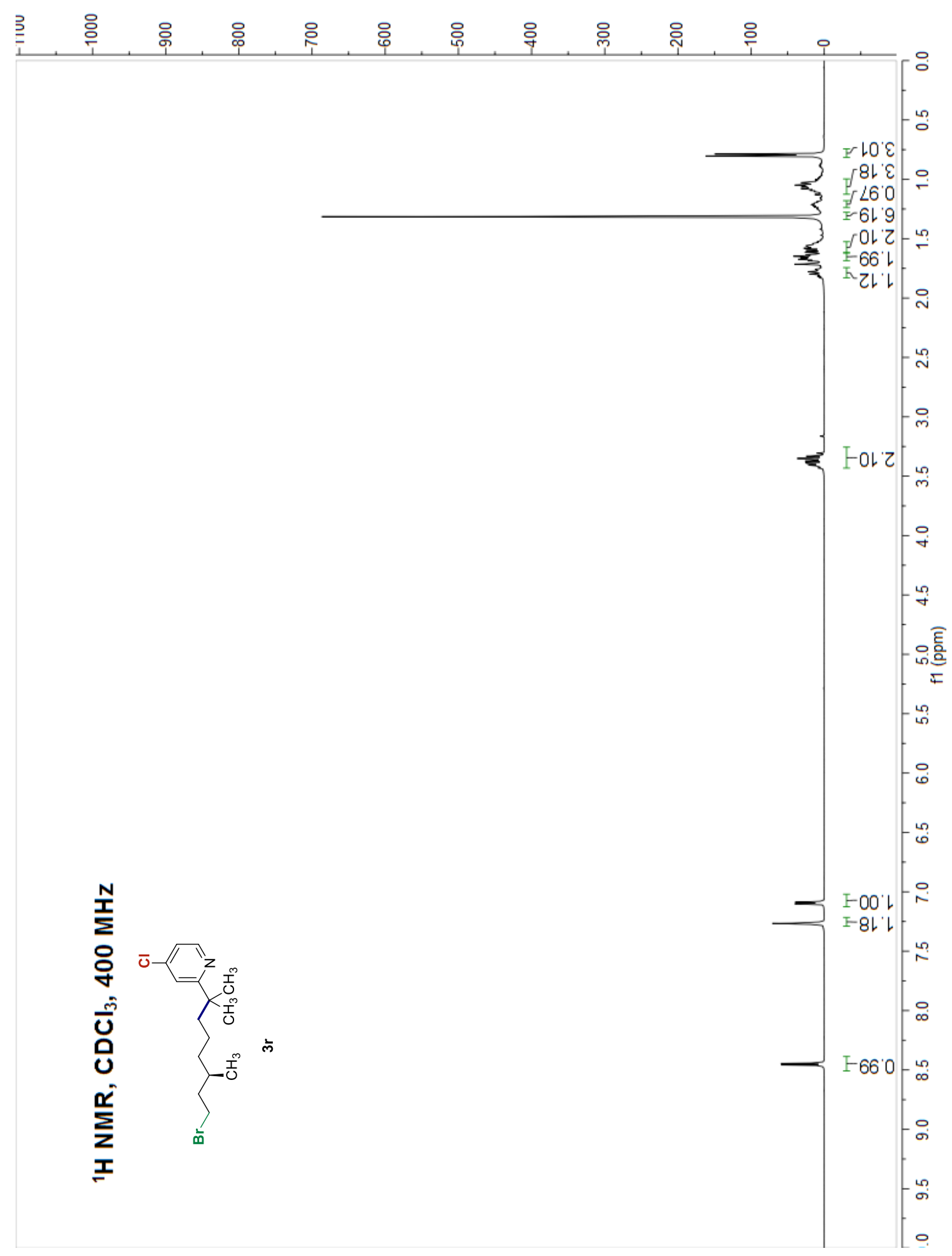




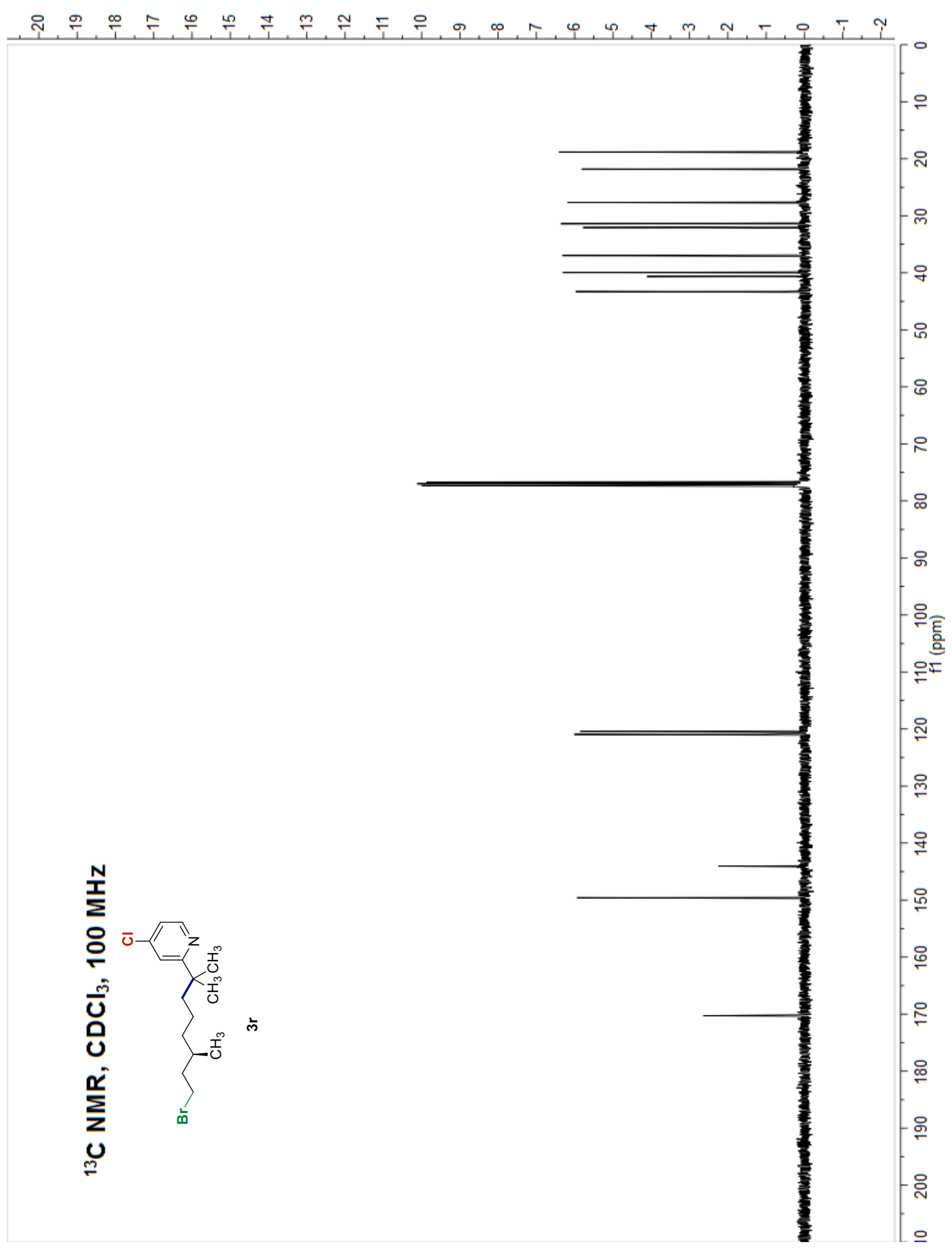




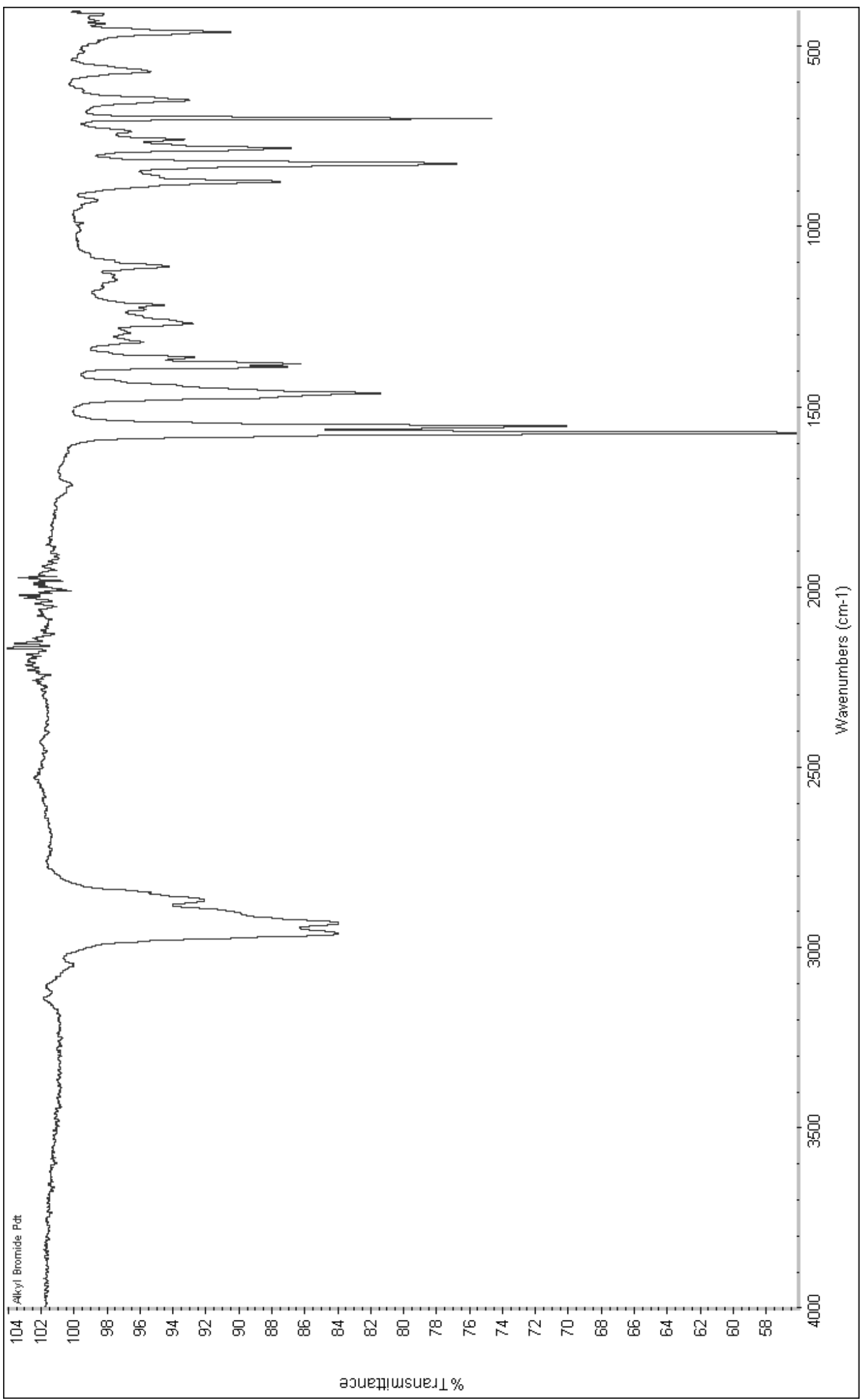

Ma and Herzon "Intermolecular hydropyridylation of unactivated alkenes" J. Am. Chem. Soc. 


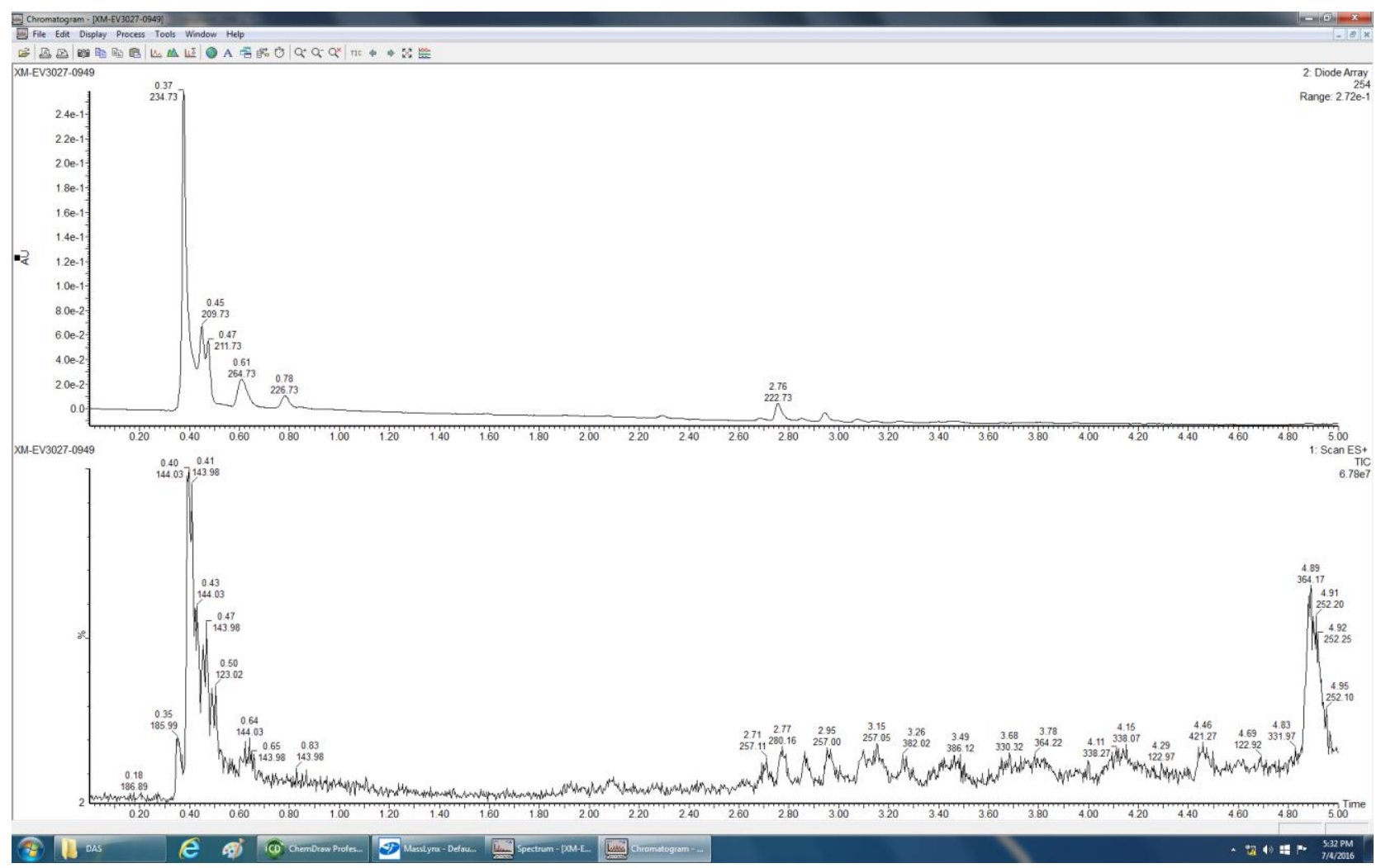




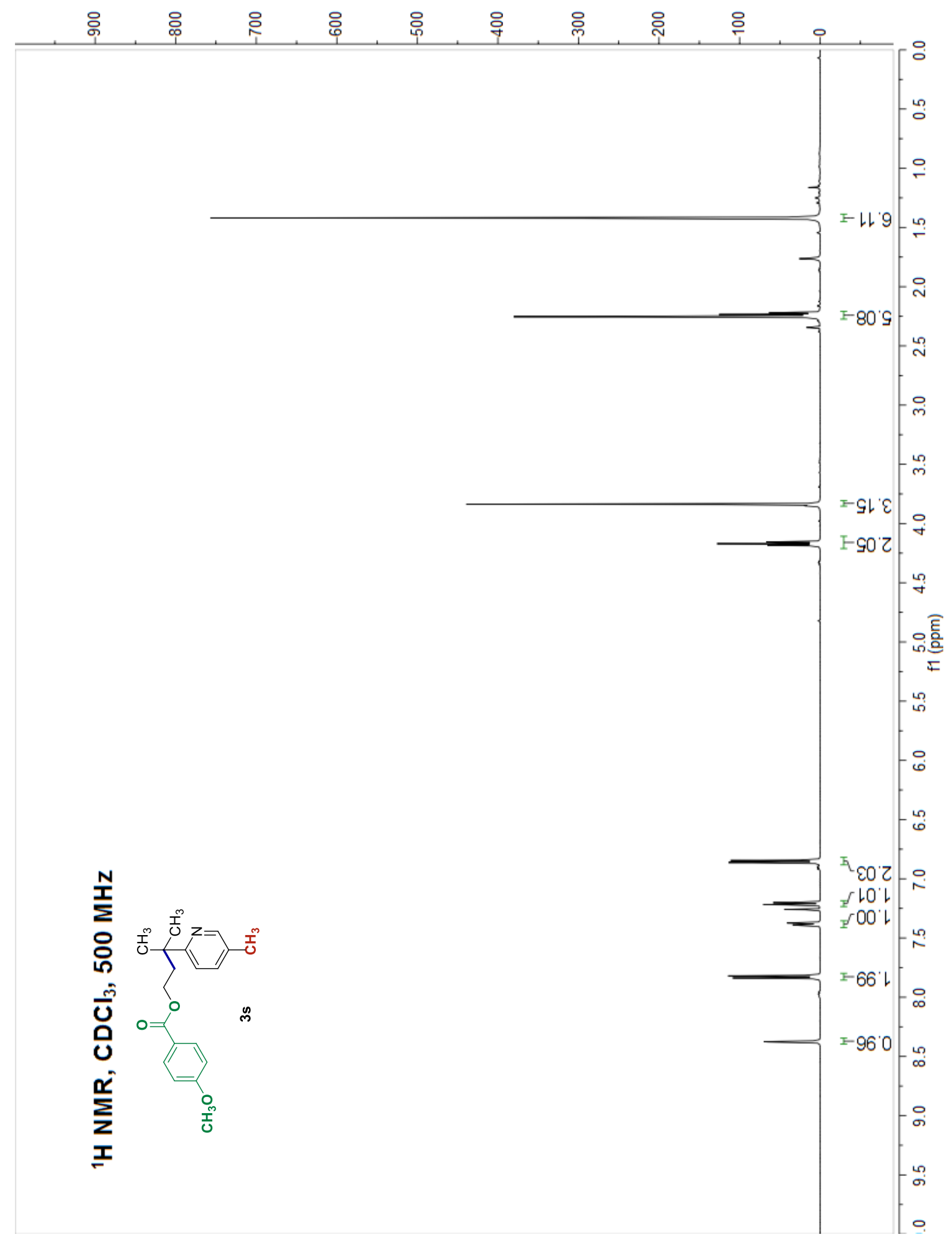




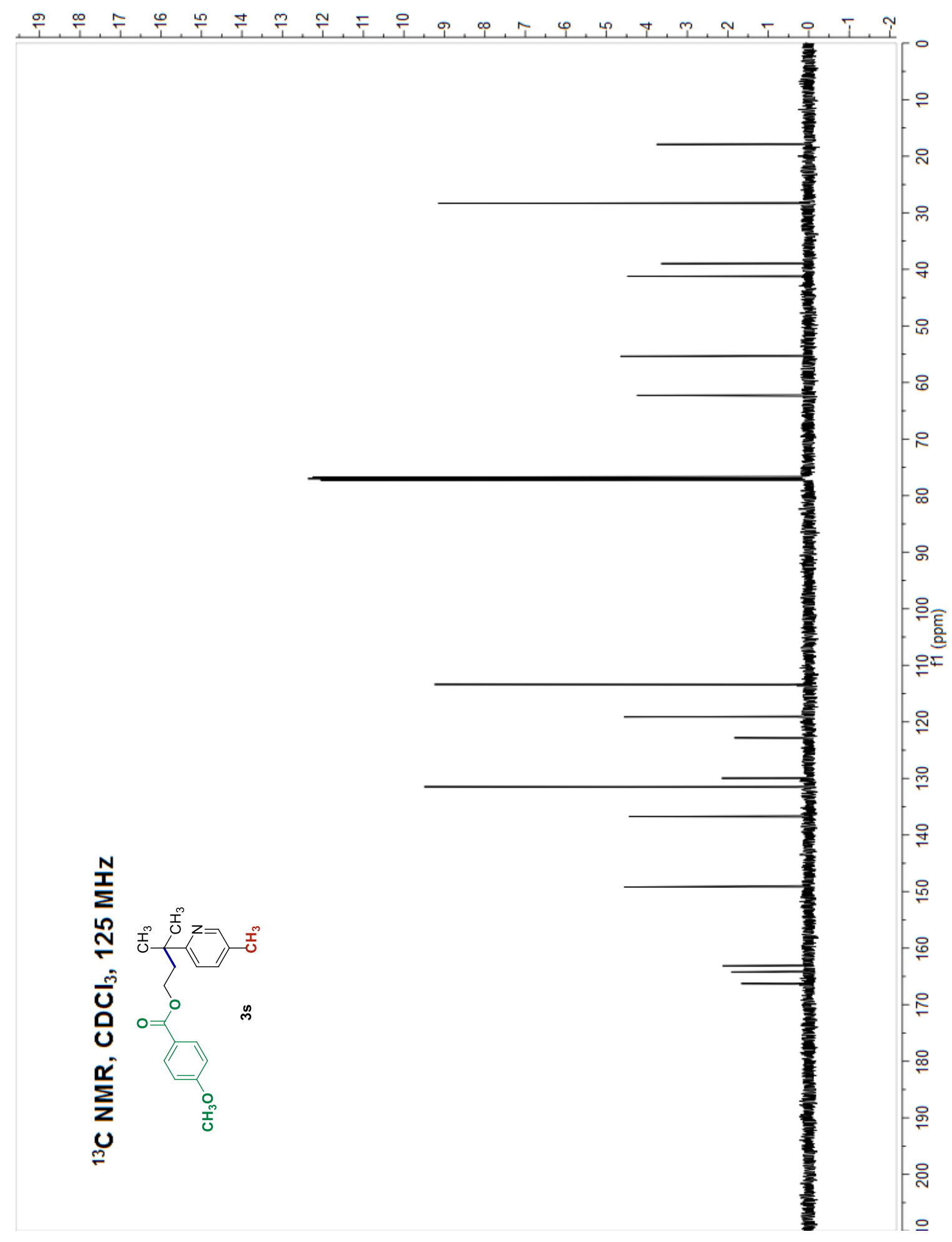




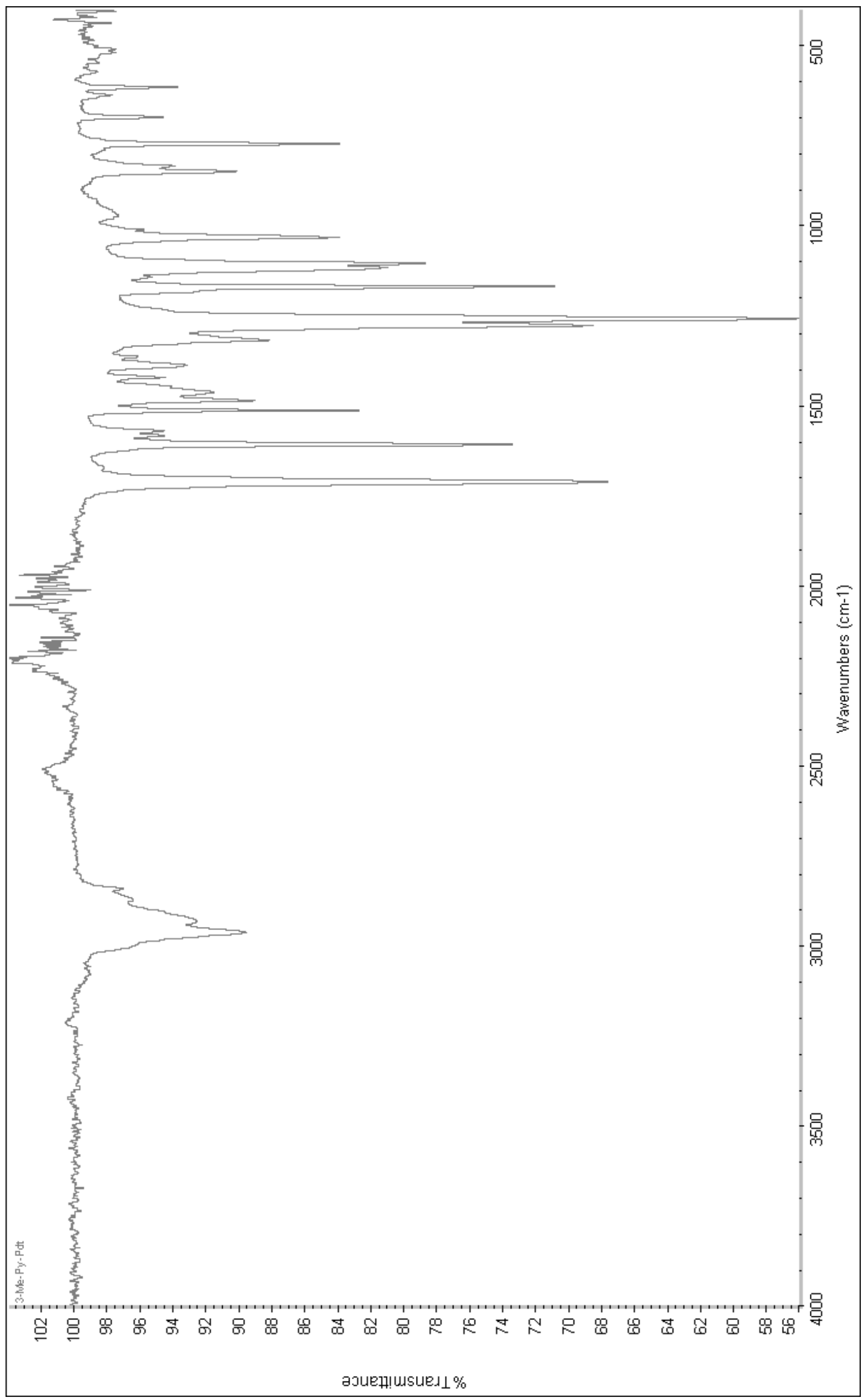

Ma and Herzon "Intermolecular hydropyridylation of unactivated alkenes" J. Am. Chem. Soc. 


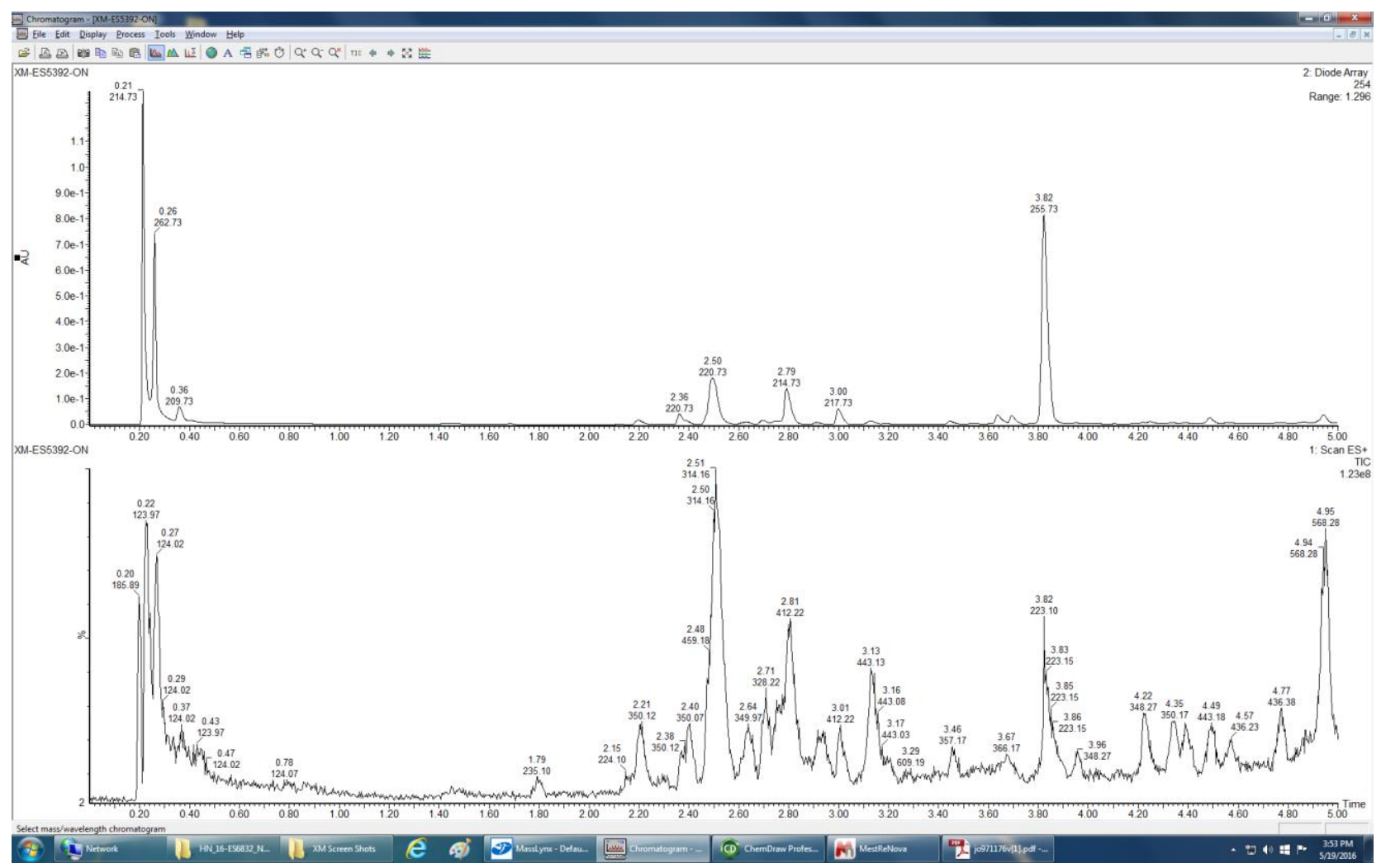




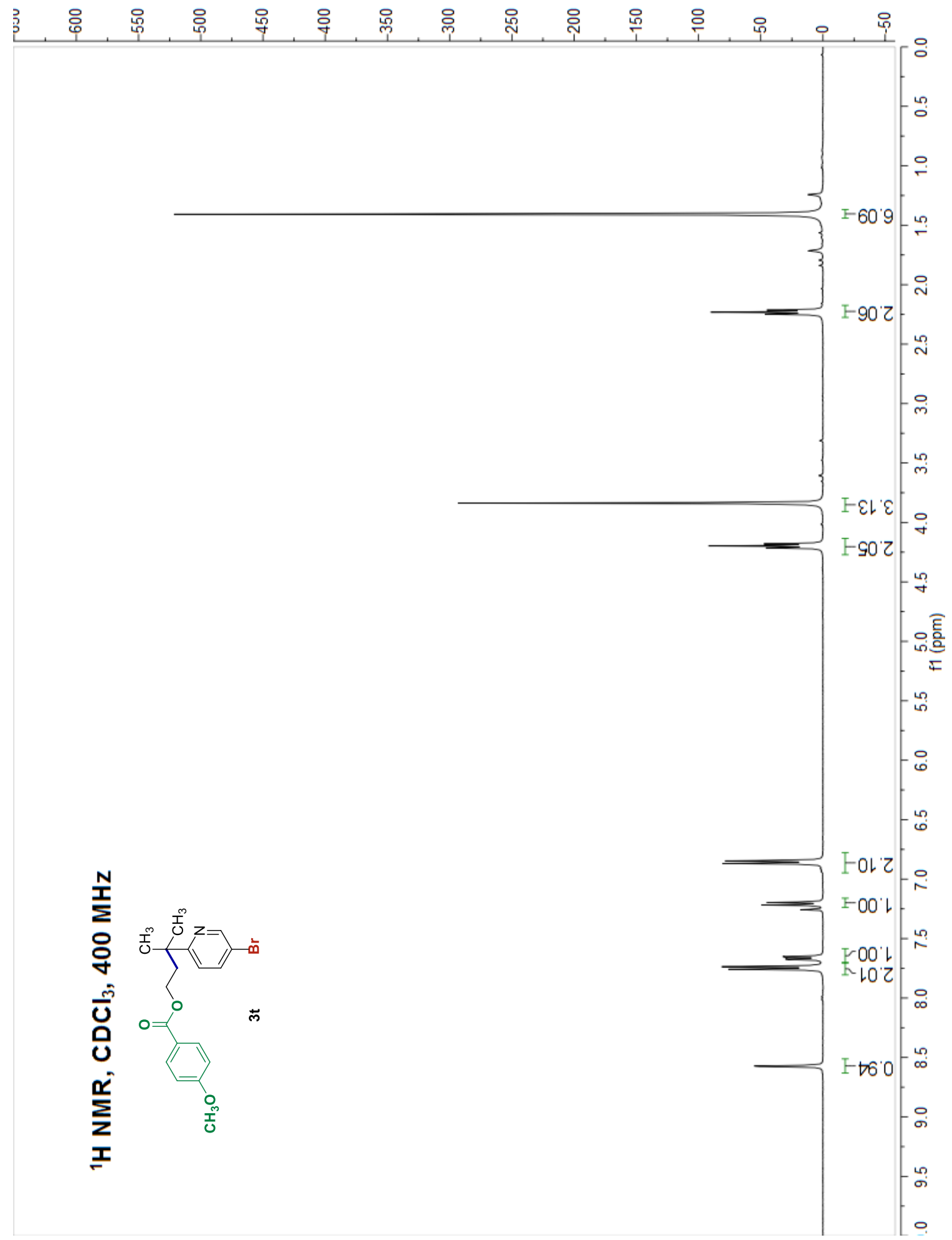




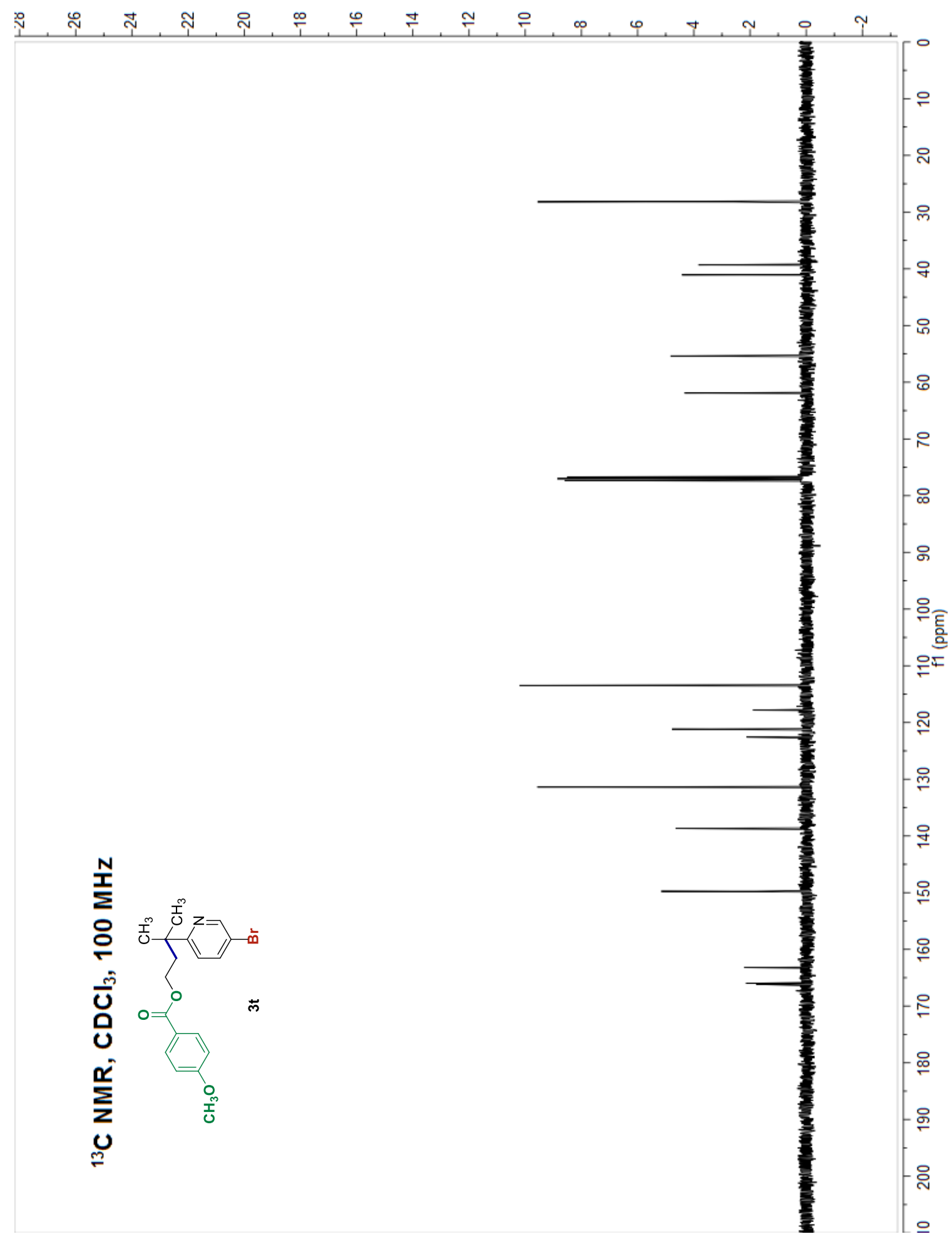




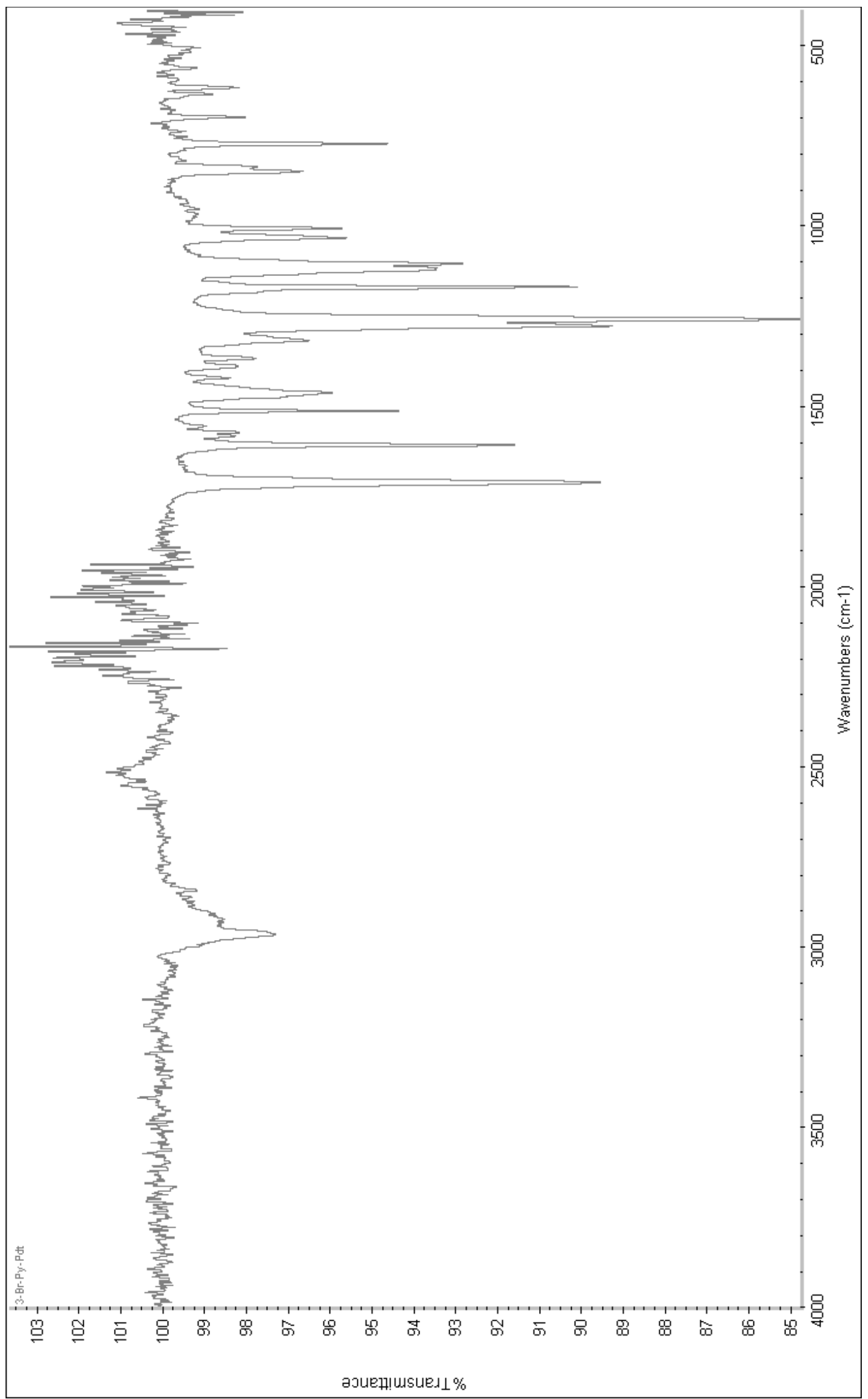

Ma and Herzon "Intermolecular hydropyridylation of unactivated alkenes" J. Am. Chem. Soc. 


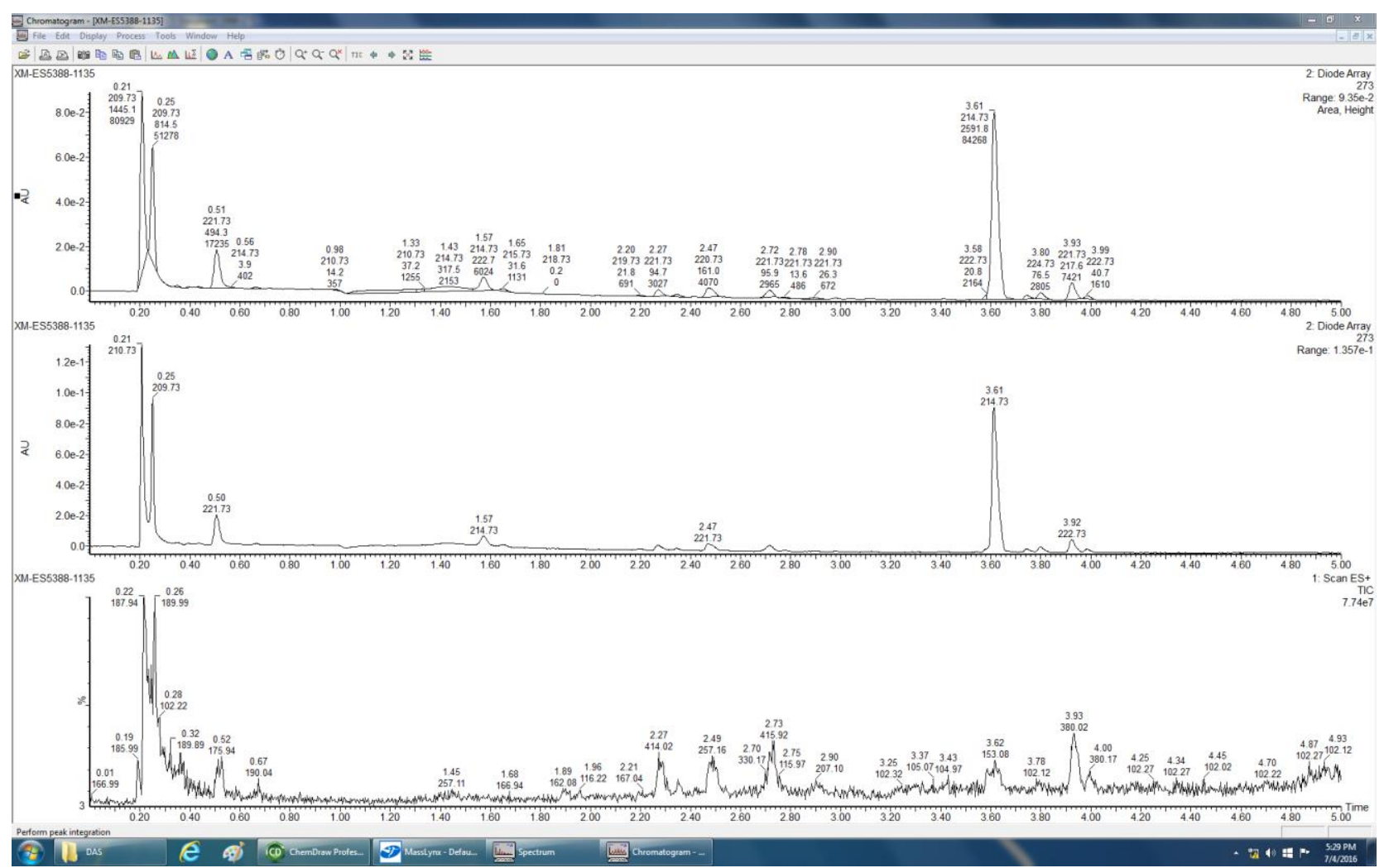




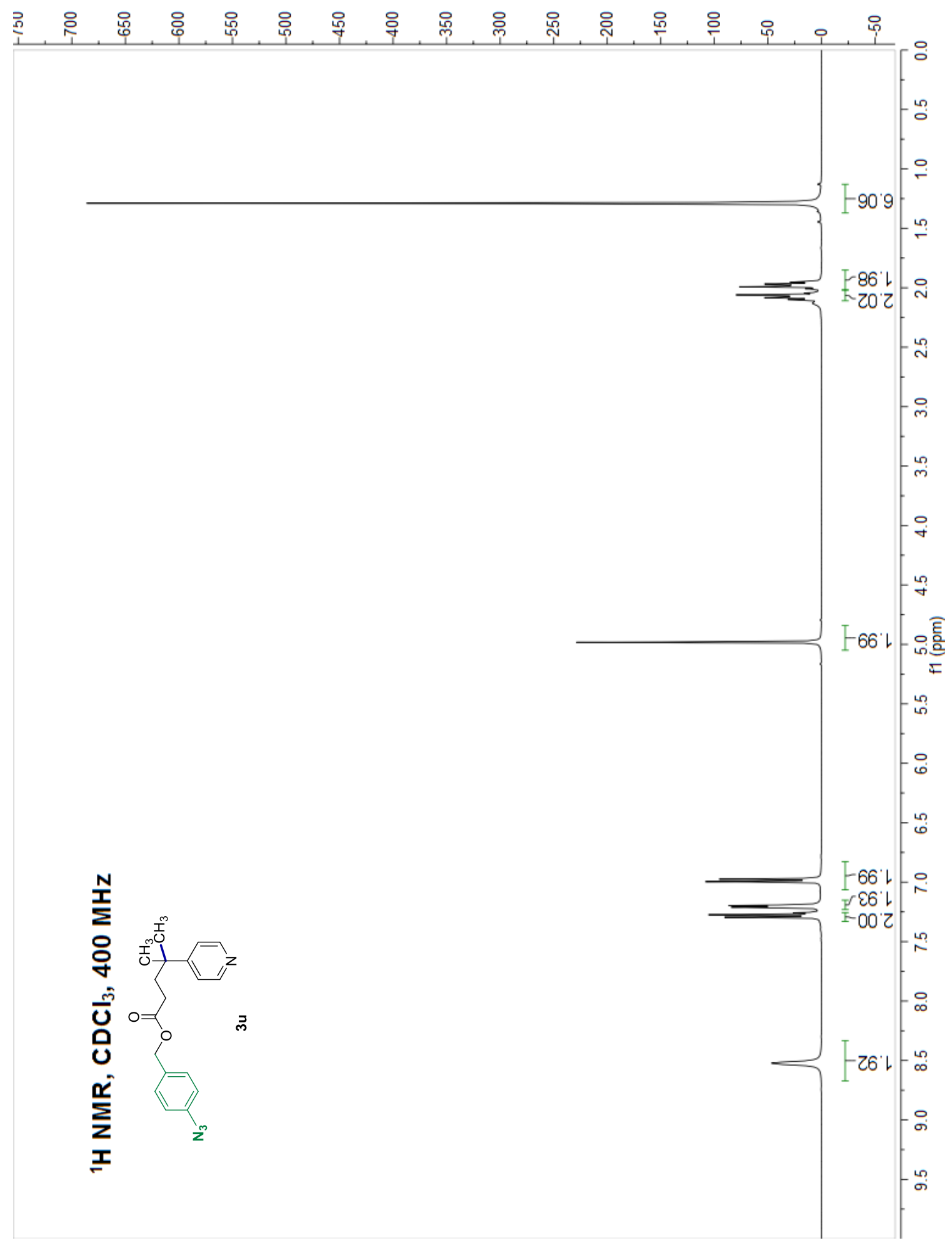




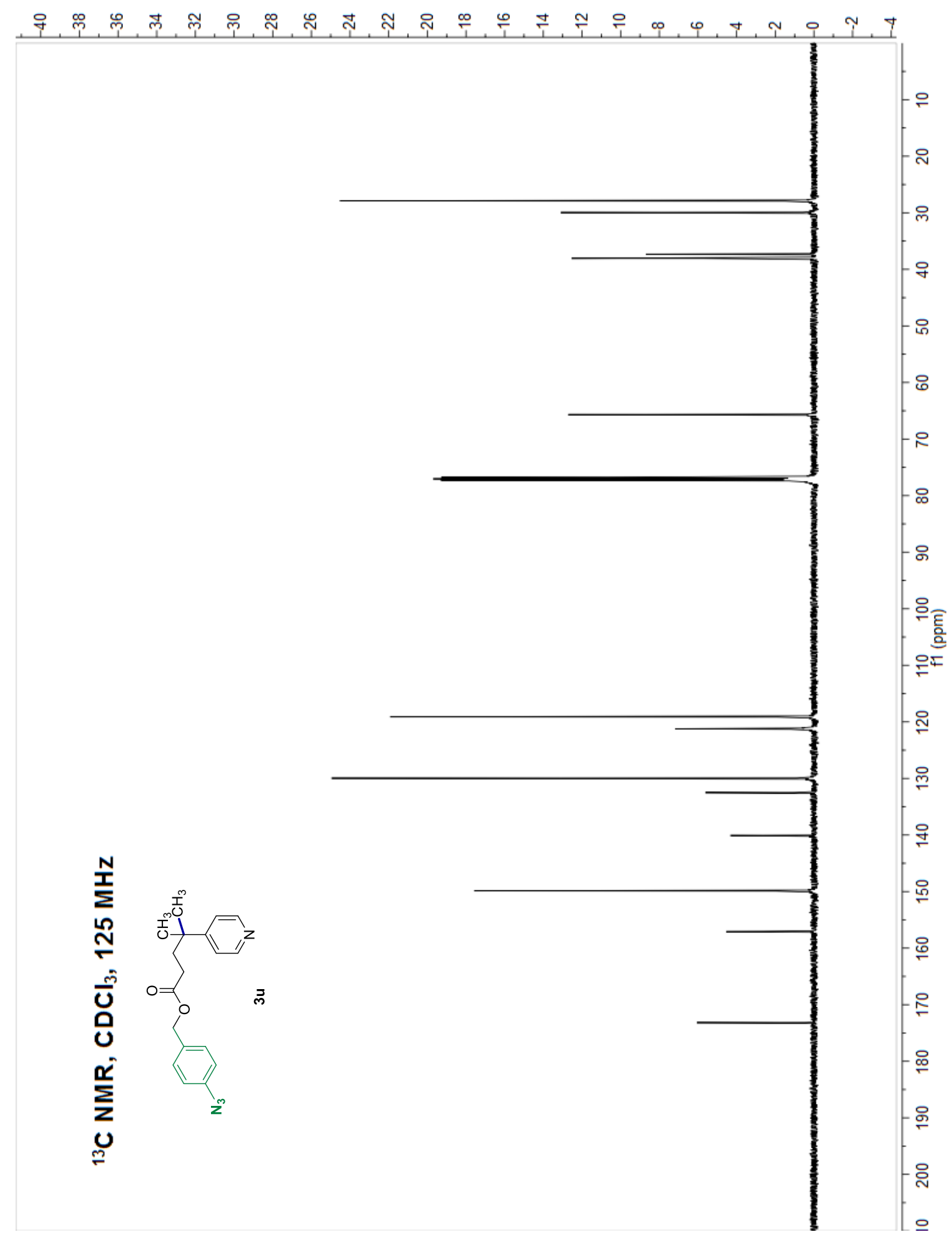




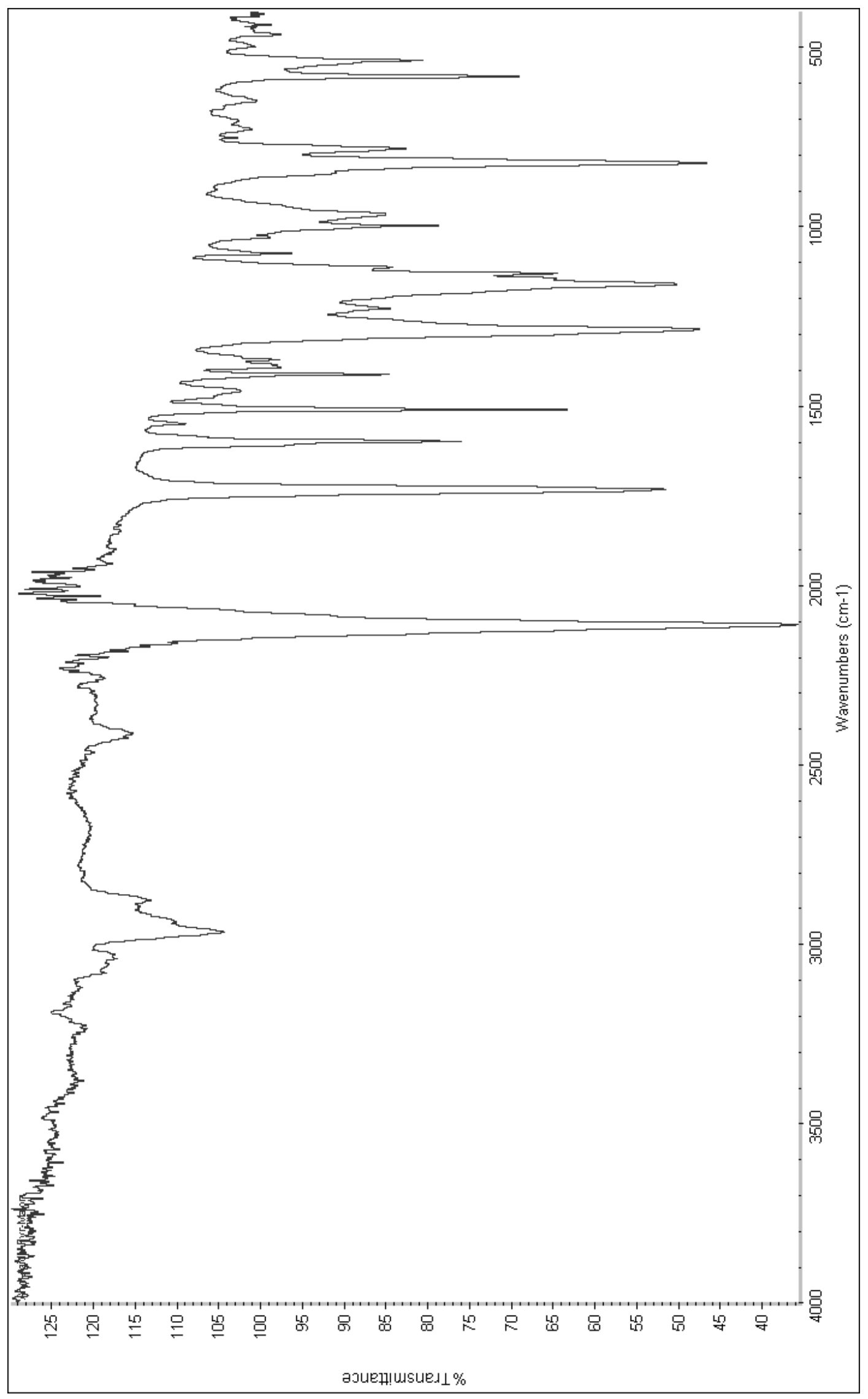




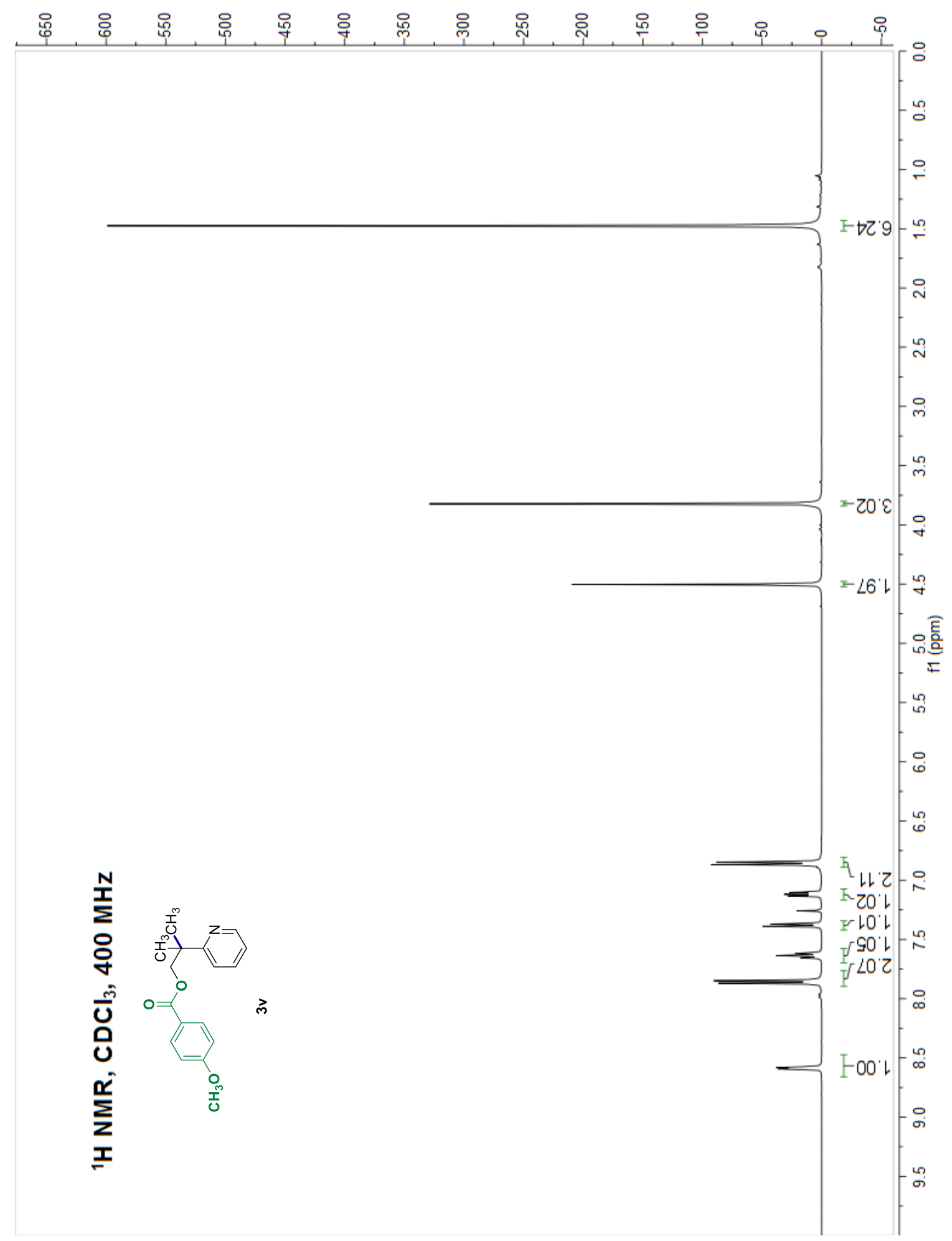




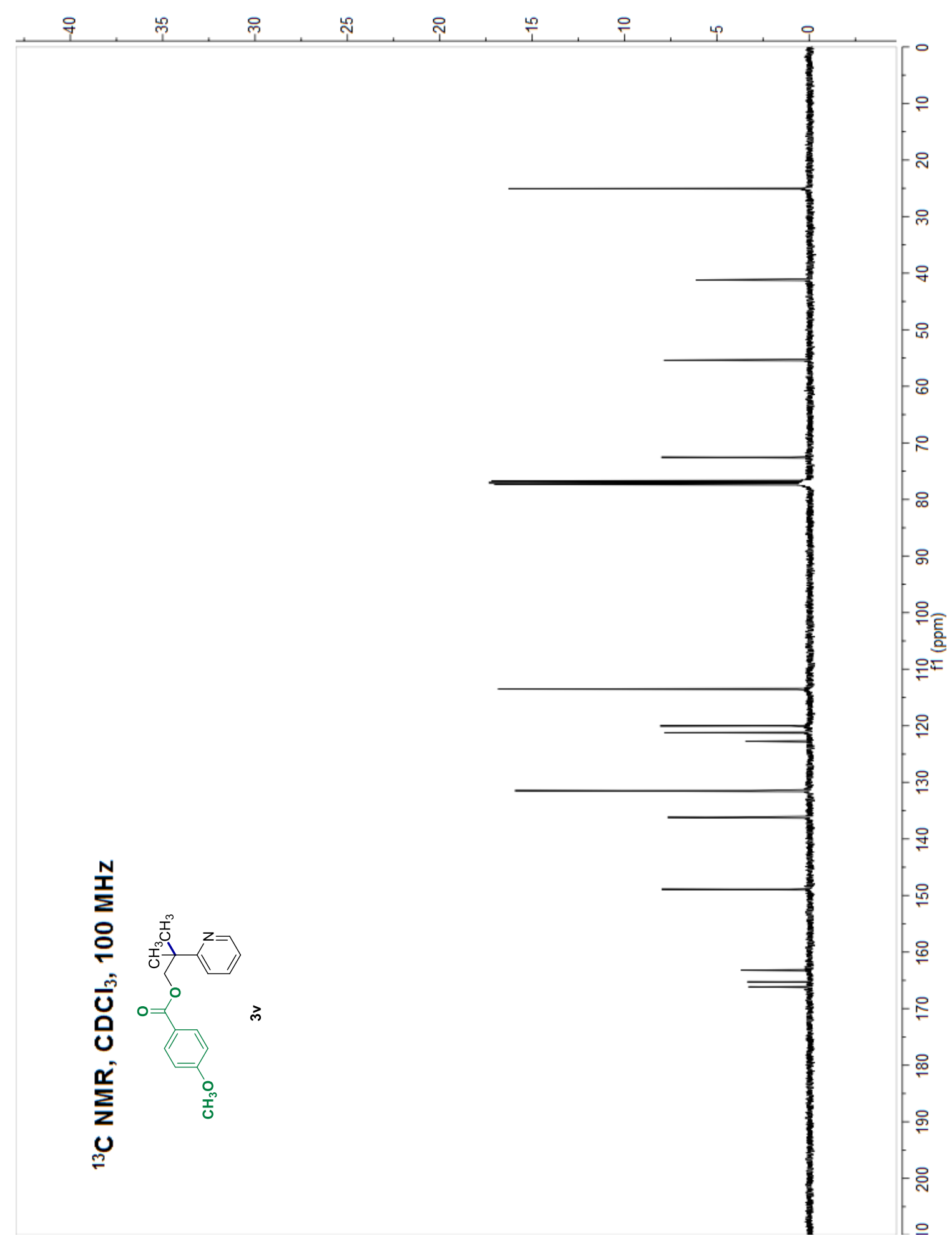




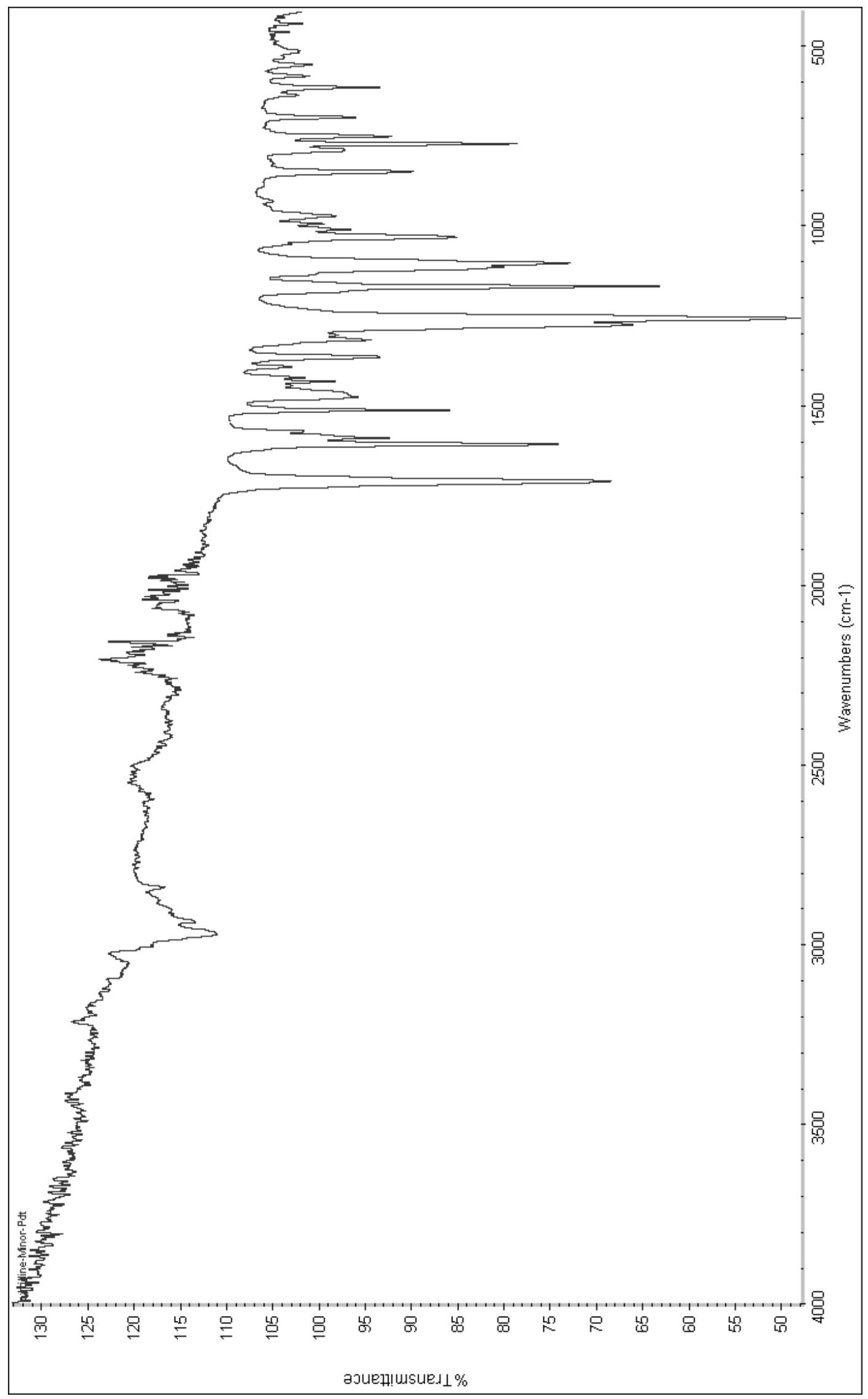

Ma and Herzon "Intermolecular hydropyridylation of unactivated alkenes" J. Am. Chem. Soc. 


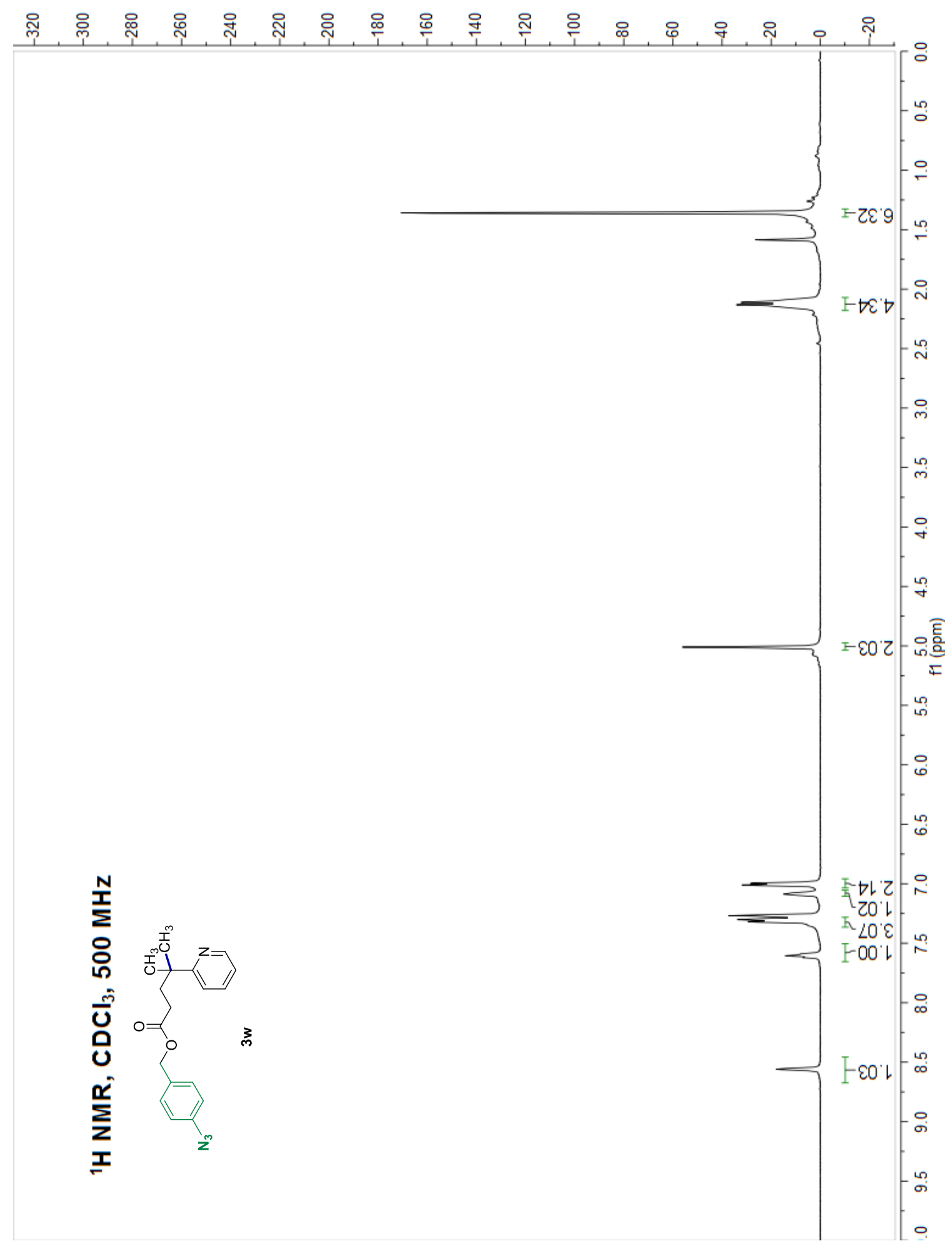




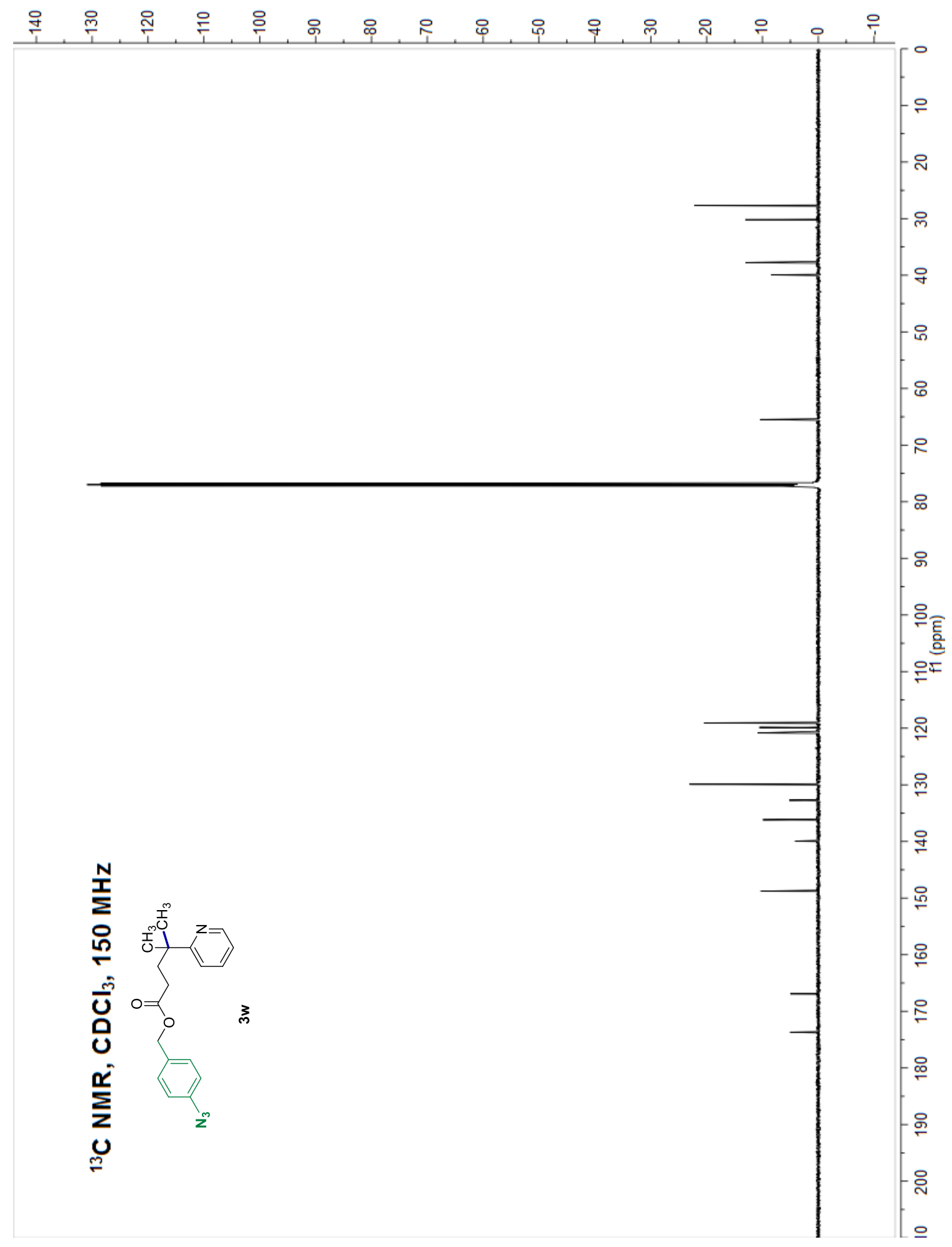




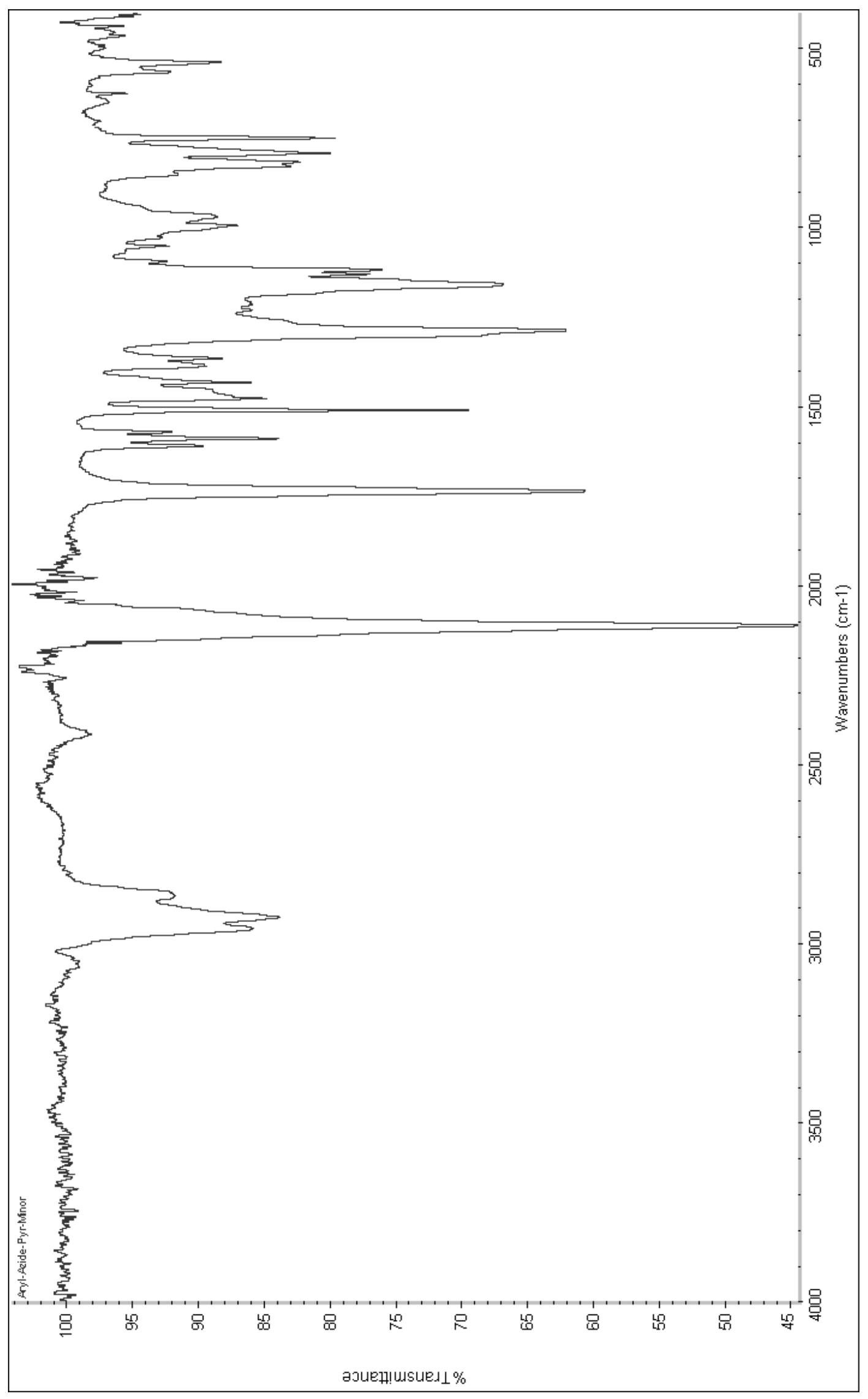

Ma and Herzon "Intermolecular hydropyridylation of unactivated alkenes" J. Am. Chem. Soc. 


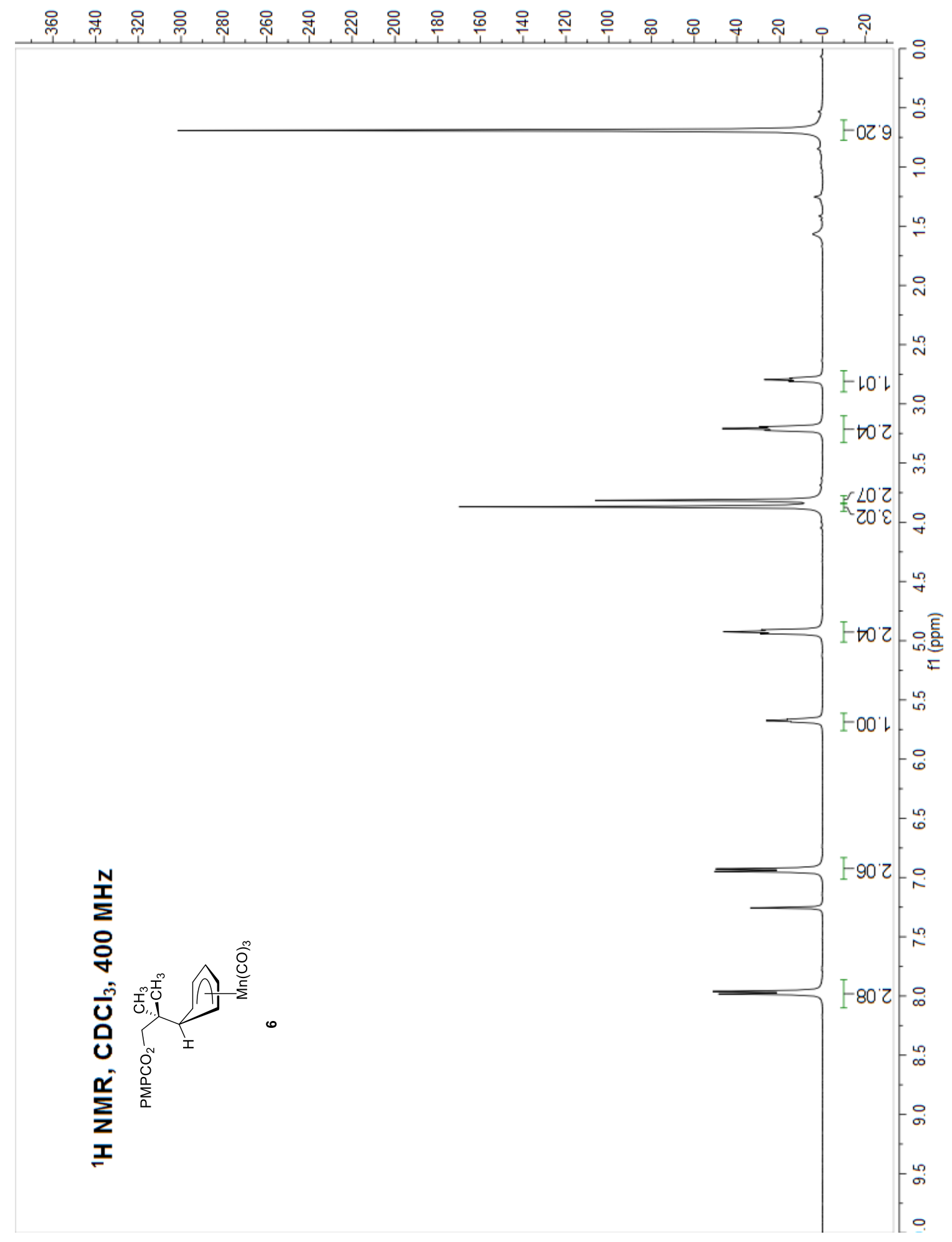




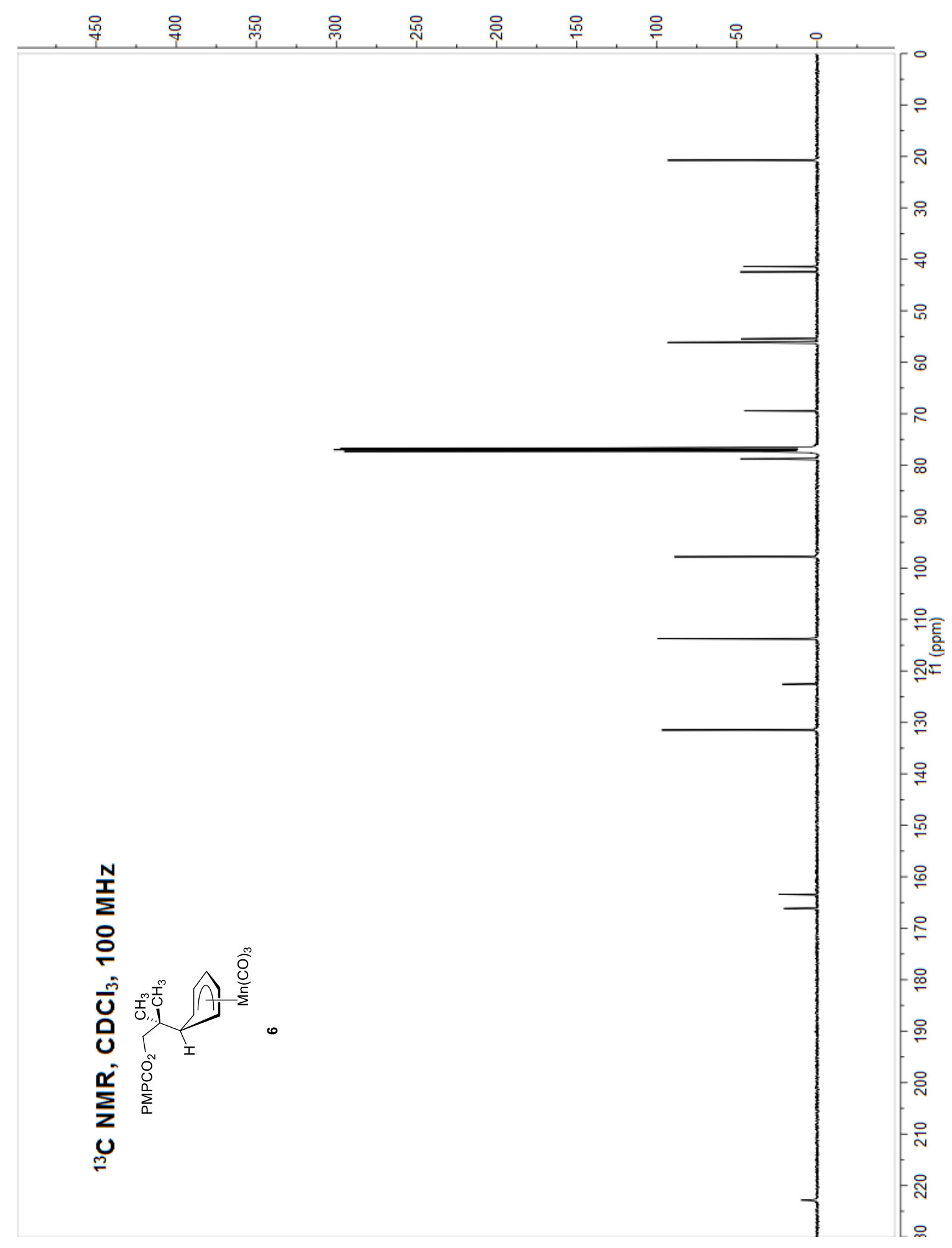




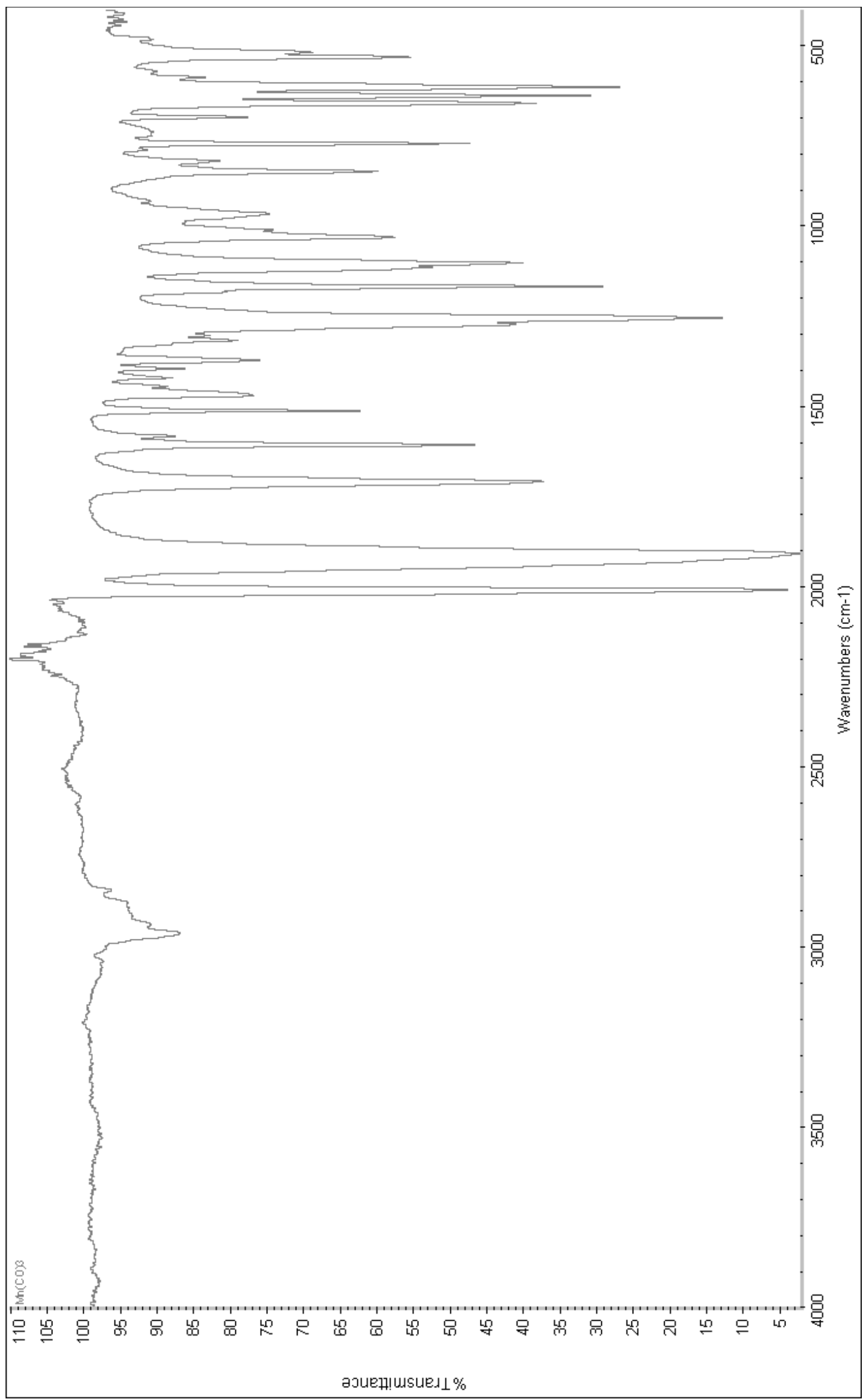

Ma and Herzon "Intermolecular hydropyridylation of unactivated alkenes" J. Am. Chem. Soc. 


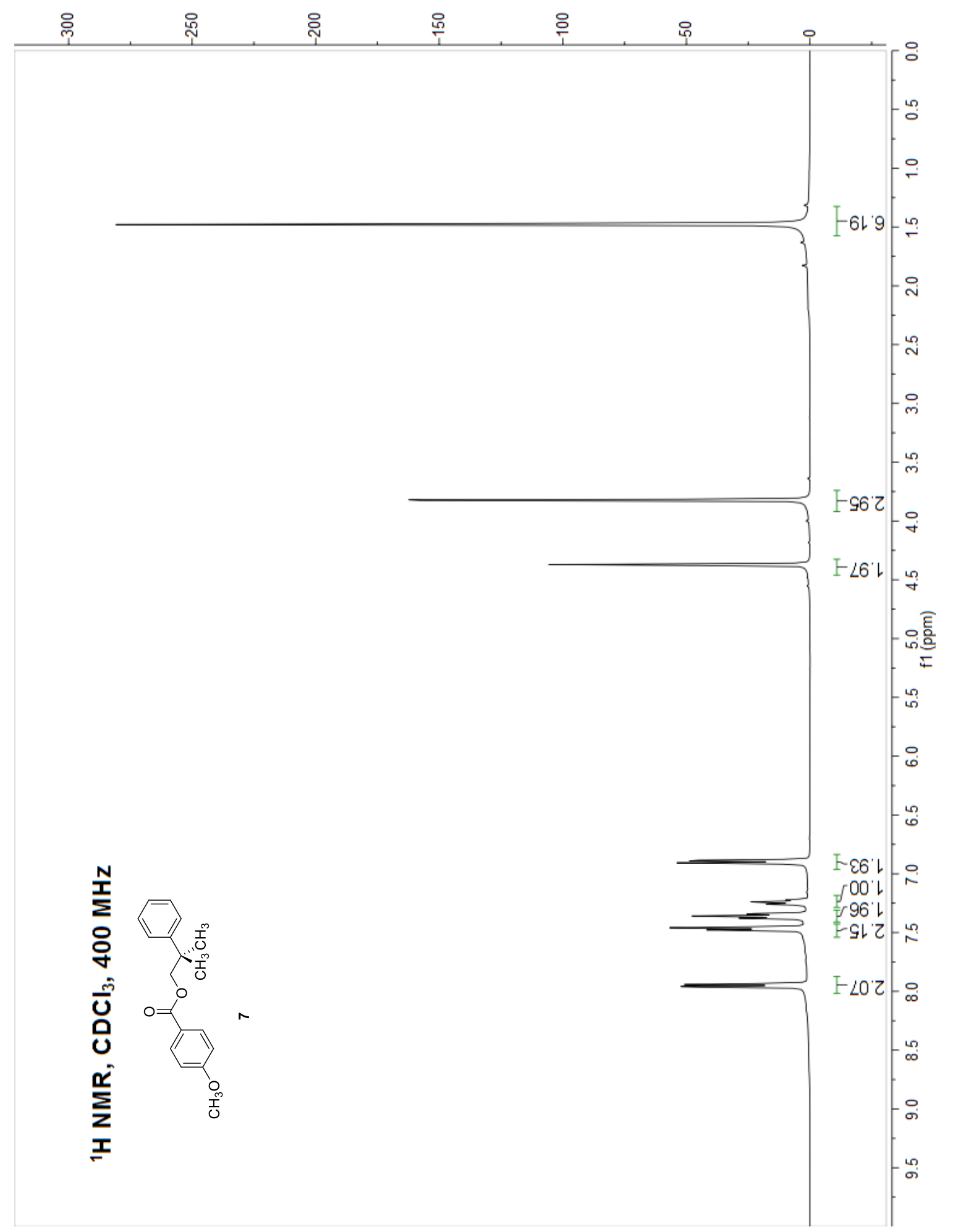




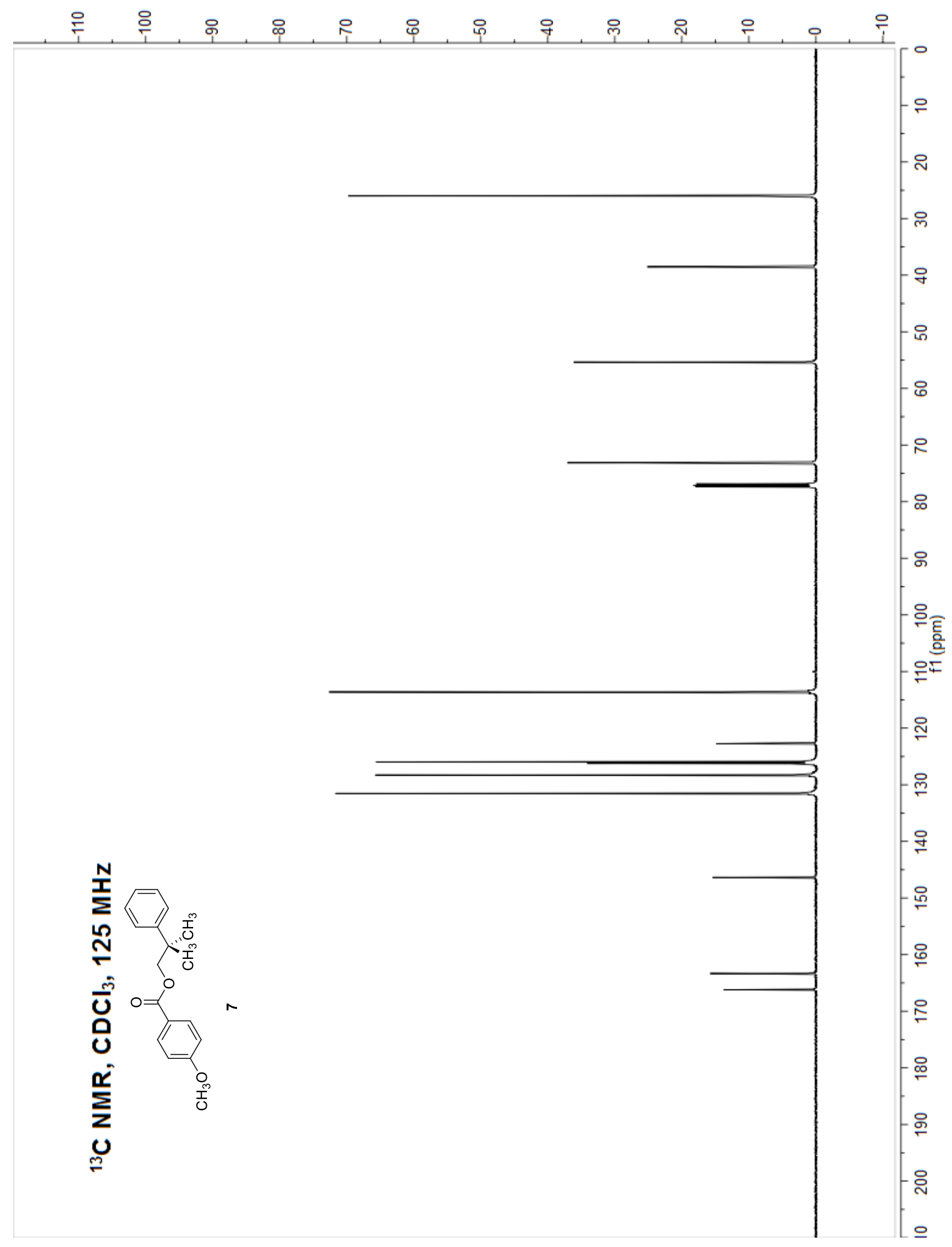




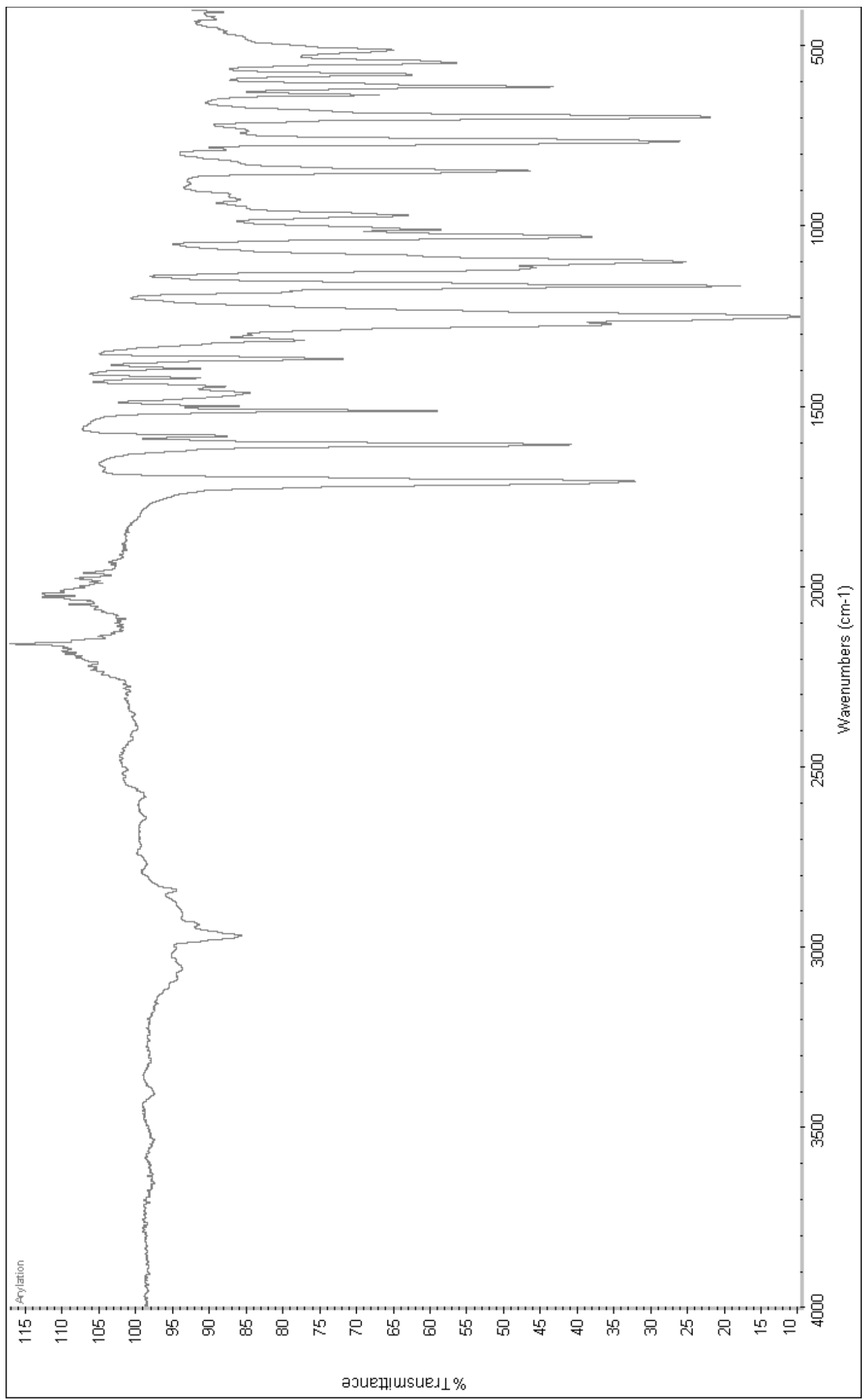

Ma and Herzon "Intermolecular hydropyridylation of unactivated alkenes" J. Am. Chem. Soc. 


\section{Bibliography:}

1. Pangborn, A. B.; Giardello, M. A.; Grubbs, R. H.; Rosen, R. K.; Timmers, F. J. Organometallics 1996, 15, 1518.

2. Devine, S. K. J.; Van Vranken, D. L. Org. Lett. 2007, 9, 2047.

3. Chen, B.; Wang, P.; Jin, Q.; Tang, X. Org. Biomol. Chem. 2014, 12, 5629.

4. Nicolai, S.; Erard, S.; González, D. F.; Waser, J. Org. Lett. 2010, 12, 384.

5. Brookhart, M.; Lamanna, W.; Pinhas, A. R. Organometallics 1983, 2, 638.

6. Kofron, W. G.; Baclawski, L. M. J. Org. Chem. 1976, 41, 1879.

7. Corey, E. J.; Guzman-Perez, A.; Noe, M. C. J. Am. Chem. Soc. 1995, 117, 10805.

8. Debnar, T.; Wang, T.; Menche, D. Org. Lett. 2013, 15, 2774.

9. Ofori, L. O.; Hilimire, T. A.; Bennett, R. P.; Brown, N. W.; Smith, H. C.; Miller, B. L. J. Med. Chem. 2014, 57, 723.

10. Ma, X.; Herzon, S. B. Chem. Sci. 2015, 6, 6250.

11. Chênevert, R.; Dasser, M. J. Org. Chem. 2000, 65, 4529.

12. Davis, F. A.; Theddu, N. J. Org. Chem. 2010, 75, 3814.

13. De Luca, L.; Giacomelli, G.; Porcheddu, A. Org. Lett. 2002, 4, 553.

14. Janjetovic, M.; Träff, A. M.; Hilmersson, G. Chem. - Eur. J. 2015, 21, 3772.

15. Lee, J.-I. Bull. Korean Chem. Soc. 2011, 32, 1765.

16. McCallum, T.; Barriault, L. Chem. Sci. 2016, 7, 4754.

17. Grasselli, J. G., Atlas of Spectral Data and Physical Constants for Organic Compounds. CRC Press: Cleveland, Ohio, 1973; p B-851. 